UNIVERSIDADE DE SÃO PAULO

FACULDADE DE FILOSOFIA, LETRAS E CIÊNCIAS HUMANAS

DEPARTAMENTO DE HISTÓRIA

PROGRAMA DE PÓS-GRADUAÇÃO EM HISTÓRIA ECONÔMICA

MARIELY DE ALBUQUERQUE MELLO FELIPE

"E A NATUREZA OS ENTREGOU AO JOGO DOS TEMPOS":

A SECA DE 1791 NA CAPITANIA DE PERNAMBUCO E SUAS ANEXAS

VERSÃO CORRIGIDA

São Paulo

2020 


\author{
UNIVERSIDADE DE SÃO PAULO \\ FACULDADE DE FILOSOFIA, LETRAS E CIÊNCIAS HUMANAS \\ DEPARTAMENTO DE HISTÓRIA \\ PROGRAMA DE PÓS-GRADUAÇÃO EM HISTÓRIA ECONÔMICA
}

\title{
"E A NATUREZA OS ENTREGOU AO JOGO DOS TEMPOS": \\ A SECA DE 1791 NA CAPITANIA DE PERNAMBUCO E SUAS ANEXAS
}

Mariely de Albuquerque Mello Felipe

\begin{abstract}
Dissertação apresentada ao Programa de Pós-
Graduação em História Econômica do

Departamento de História da Faculdade de

Filosofia, Letras e Ciências Humanas da

Universidade de São Paulo para a obtenção do

título de Mestre em História
\end{abstract}

Orientador: Prof. ${ }^{\text {o }}$ Dr. ${ }^{\circ}$ Maximiliano M. Menz

São Paulo

2020 
Autorizo a reprodução e divulgação total ou parcial deste trabalho, por qualquer meio convencional ou eletrônico, para fins de estudo e pesquisa, desde que citada a fonte.

Catalogação na Publicação

Serviço de Biblioteca e Documentação

Faculdade de Filosofia, Letras e Ciências Humanas da Universidade de São Paulo

\begin{tabular}{|c|c|}
\hline $\mathrm{F} 313$ & $\begin{array}{l}\text { Felipe, Mariely de Aibuquerque Mello } \\
\text { "E a natureza os entrego do jogo dos tempos": a } \\
\text { seca de } 1791 \text { na capitania de Pernambuco e suas } \\
\text { anexas. / Marie-y de Albuquerque Mello Eelipe ; } \\
\text { orientador Maximiliano Mac Menz. - Sảo Paulo, } 2020 \text {. } \\
130 \mathrm{f} \text {. }\end{array}$ \\
\hline & $\begin{array}{l}\text { Dissertaçâo (Mestrado)- Faculdade de Filosofia, } \\
\text { Letras e C:êcias Humanas da Universidade de Săo } \\
\text { Paulo. Departamento de História. Area de concentraço: } \\
\text { História Econôm:ca. }\end{array}$ \\
\hline & $\begin{array}{l}\text { 1. História Ambiental. 2. Seca. 3. Capitania Geral } \\
\text { de Pernambuco. 4. Secalo xvili. } 5 \text {. Abastecimento. I. } \\
\text { Meaz, Maximiliano Mac, ox-eat. II. Titulo. }\end{array}$ \\
\hline
\end{tabular}




\section{ENTREGA DO EXEMPLAR CORRIGIDO DA DISSERTAÇÃO/TESE}

\section{Termo de Ciência e Concordância do (a) orientador (a)}

\section{Nome do (a) aluno (a): Mariely de Albuquerque Mello Felipe}

Data da defesa: $20 / 08 / 2020$

Nome do Prof. (a) orientador (a): Maximiliano M. Menz

Nos termos da legislação vigente, declaro ESTAR CIENTE do conteúdo deste EXEMPLAR CORRIGIDO elaborado em atenção às sugestões dos membros da comissão Julgadora na sessão de defesa do trabalho, manifestando-me plenamente favorável ao seu encaminhamento e publicação no Portal Digital de Teses da USP.

São Paulo, $16 / 10$ /2020

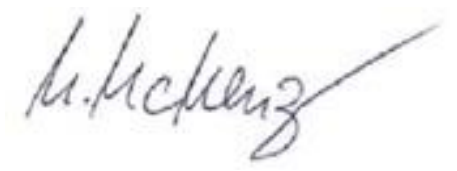

(Assinatura do (a) orientador (a) 


\section{Agradecimentos}

Gratidão é um dos sentimentos mais importantes que qualquer pessoa pode, e deve, ter. Finalizar esta dissertação não foi uma tarefa fácil, quem acompanhou esse processo de perto sabe disso, e teria sido impossível sem o auxílio e o apoio de uma infinidade de pessoas.

Primeiramente, gostaria de agradecer aos meus pais, Elton e Lucimar, pela minha vida e por todo amor que sempre me ofertaram. Por todo esforço empenhado na minha criação e por procurarem sempre me oferecer o melhor que podiam. A vocês eu devo o que sou. À voinha e voinho, Marluce ( in memorian) e Lucídio ( in memorian), por terem sido meus segundos pais, pelo exemplo, por todo amor que sempre demonstraram por mim, e por terem me proporcionado uma infância extremamente feliz. Ao meu irmão, Lucídio Neto, por há quinze anos ter tornado a minha vida mais completa, despertando em mim um amor sem tamanho.

Ao meu companheiro de vida e amigo, Raphael, que acompanhou de perto as minhas alegrias e angústias ao longo desse processo. Obrigada pelo companheirismo, carinho e amor.

À minha família Timbaubense, tios, tias e primos, de sangue ou não, por me proporcionarem momentos alegres e por sempre estarem presentes nos momentos difíceis. A Vó Maria e Vô Tonho, pelo amor e orgulho que sempre demonstraram por mim. Obrigada por fazerem de Timbaúba uma terceira casa.

Agradeço imensamente a Maximiliano M. Menz, pela orientação, paciência e compreensão diante das minhas dificuldades ao longo do caminho. Sem as suas contribuições essa dissertação não seria possível.

À Fundação de Amparo à Pesquisa do Estado de São Paulo (FAPESP), pelo apoio financeiro durante esta pesquisa, através do processo n ${ }^{\circ}$ 17/10169-3. E à Coordenação de Aperfeiçoamento de Pessoal de Nível Superior (CAPES). Sem esse suporte, o desenvolvimento desta pesquisa não teria acontecido.

A Gustavo Acioli e Janes Jorge pelas contribuições, críticas e sugestões durante a minha banca de qualificação.

A todos os funcionários de arquivos que facilitaram a minha pesquisa e fizeram o possível para que eu pudesse encontrar o que procurava. Em especial, agradeço a Hildo Leal e a Emerson, do Arquivo Público Jordão Emerenciano, e a George Cabral, Galvão e Seu Cabral, do Instituto Arqueológico, Histórico e Geográfico Pernambucano. 
À Claydja, Xuxu, pela amizade, por estar sempre disposta a me ajudar e a me fazer rir, mesmo nos momentos mais difíceis. Obrigada por me mostrar que a distância física não muda nada.

À Maria Angélica Pedrosa, por todos conselhos, carinho e suporte. Obrigada por ter tornado o caminho diário menos árido, minha amiga.

À Ana Cecília de Alencar, pela companhia em várias disciplinas da pós, pelas ideias trocadas, pelos encontros na biblioteca e por ter me fornecido boa parte da documentação cearense utilizada neste trabalho.

À Iara dos Santos, por todas conversas profícuas sobre a minha pesquisa, pela amizade e por me escutar quando as coisas não iam muito bem.

A Felipe Souza, André Paiva e Diego Martins por todas as dicas e pelo auxílio no aprimoramento do meu projeto de pesquisa.

À Suely Almeida, por ter me acolhido como orientanda na graduação e por ter me apresentado ao mundo da pesquisa.

Aos meus queridos amigos e vizinhos da Estrada São Francisco, Flávia, Jardeson, Luiz e Viviane, pelos encontros e risadas.

À Jéssica Sousa, pelos encontros em São Paulo e pelas conversas sobre o sertão.

Aos meus padrinhos Kátia e Raimundo, por se fazerem presentes nos momentos de alegrias e tristezas, e por terem fé em tudo que eu faço.

À Carol, por todos os momentos vividos, e pela amizade.

Agradeço a todos que contribuíram direta ou indiretamente na construção deste trabalho. 
O grande desamparo em que a Providência e a natureza os entregou ao jogo dos tempos, os encheu de receios e de temores tantos, que se viram obrigados por tudo a procurar, ávidos da conservação da cara vida, que é preciosa e lastimável ao homem, o sustento naquilo que o mesmo acaso lhes desamparava.

Joaquim José Pereira, 1794. 


\begin{abstract}
Resumo
O principal objetivo desta dissertação foi analisar a seca que assolou as Capitanias de Pernambuco e suas anexas entre os anos de 1791 e 1793, e compreender as implicações sociais e econômicas desse fenômeno ao longo da última década do século XVIII. A ocorrência de longos períodos de estiagem foi frequente na região, onde tempos favoráveis alternaram-se incessantemente com períodos de baixa ou ausência de pluviosidade. Apesar do caráter secular do fenômeno, anterior à chegada dos colonos portugueses, foi no século XVIII que os registros sobre faltas de chuvas se tornaram mais frequentes, não pela repetição do fenômeno em si, mas pelo crescimento da população ligada a atividades agrícolas e pecuárias que passaram a se estabelecer em uma região climaticamente mais instável, o sertão. A "grande seca" de 1791 foi relatada como um cenário de grande devastação, escassez e fome, de norte a sul das capitanias do Norte. A perda de colheitas e a morte de rebanhos no sertão, fez surgir uma crise alimentar grave e duradoura, que extrapolou as fronteiras locais e afetou outras capitanias. O potencial devastador do fenômeno esteve intimamente ligado as circunstâncias específicas do mercado de abastecimento de finais do século XVIII.
\end{abstract}

Palavras-chave: História ambiental; Seca; Capitania Geral de Pernambuco; Século XVIII; Abastecimento.

\begin{abstract}
The main objective of this dissertation was to analyze the drought that affected the Captaincies of Pernambuco and its annexes between the years 1791 and 1793, and to understand the social and economic implications of this phenomenon throughout the last decade of the 18th century. The occurrence of long periods of drought was frequent in the region, where favorable times alternated incessantly with periods of low or absence of rainfall. Despite the secular nature of the phenomenon, prior to the arrival of Portuguese colonists, it was in the 18th century that records of lack of rain became more frequent, not because of the repetition of the phenomenon itself, but because of the growth of the population linked to agricultural and livestock activities that they started to establish themselves in a more climatically unstable region, the hinterland. The "great drought" of 1791 was reported as a scenario of great devastation, scarcity and famine, from north to south of the northern captaincies. The loss of crops and the death of herds in the hinterland, brought about a serious and lasting food crisis, which went beyond the local borders and affected other captaincies. The devastating potential of the phenomenon was closely linked to the specific circumstances of the supply market in the late 18th century.

Key-words: Environmental History; Draught; General Captaincy o Pernambuco; XVIII century; Food supply
\end{abstract}




\section{Lista de Figuras}

Figura 1 - O terreiro dos Coqueiros em 1641.

\section{Lista de Mapas}

Mapa 1 - Rotas de penetração da pecuária

Mapa 2 - Vilas e Freguesias que produziam excedentes de alimentos na Capitania Geral de Pernambuco na segunda metade do século XVIII

\section{Lista de Quadros}

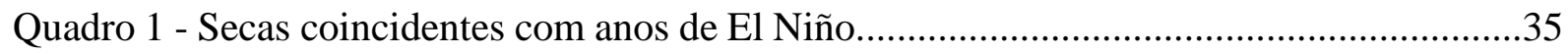

Quadro 2 - População do Sertão do Rio Grande do Norte ( 1774)............................................58

Quadro 3 - População do Sertão do Ceará (1774).........................................................................59

Quadro 4 - População do Sertão de Pernambuco (1774)...............................................................59

Quadro 5 - População do Sertão da Paraíba (1774) .................................................................59

Quadro 6 - Mapa de exportação de produtos da capitania da Paraíba do Norte no ano de 1798.

Quadro 7 - Produção de gêneros de primeira necessidade no sertão da Capitania da Paraíba no ano de 1798.

Quadro 8 - Mapa comparativo de produção, consumo e exportação das vilas da capitania do Rio Grande do Norte .71

Quadro 9 - Mapa geral do Sertão da Ribeira do Apodi em 1792. .72

\section{Lista de Tabelas}

Tabela 1 - Distribuição de Sesmarias na capitania do Ceará (1679 - 1824).

Tabela 2 - Médias anuais de distribuição de Sesmarias na Capitania da Paraíba

Tabela 3 - Escravos exportados para Pernambuco e a estimativa da farinha empregada no tráfico por ano $(1780-1800)$ .89

Tabela 4 - Entradas de sal e saídas de carnes do Porto do Aracati (1767-1796)...... 128 


\section{Abreviações}

AHU - Arquivo Histórico Ultramarino

AL - Alberto Lamego

APEJE - Arquivo Público Jordão Emerenciano (Arquivo Público de Pernambuco)

BNRJ - Biblioteca Nacional do Rio de Janeiro

Cx. - Caixa

D. - documento

IAHGP - Instituto Arqueológico, Histórico e Geográfico Pernambucano

IHGRN - Instituto Histórico e Geográfico do Rio Grande do Norte 


\section{Sumário}

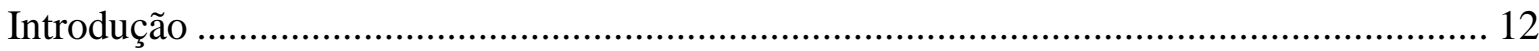

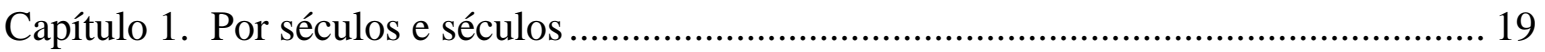

Sertão e natureza nas capitanias de Pernambuco e Anexas ............................................... 19

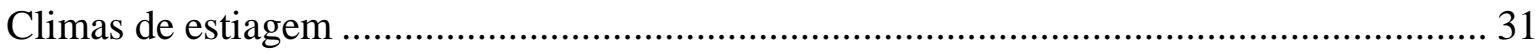

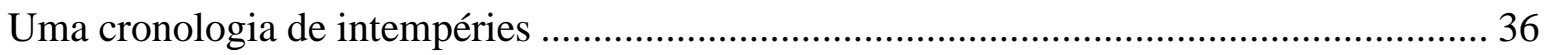

Capítulo 2. Produção de alimentos e abastecimento na Capitania de Pernambuco e Anexas

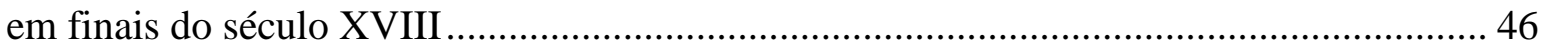

A pecuária e o seu papel na produção do território.................................................................. 47

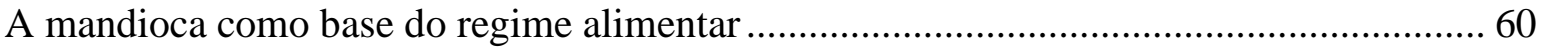

A produção de alimentos nas capitanias de Pernambuco e anexas na segunda metade do

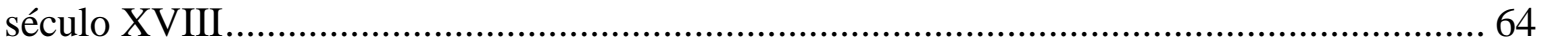

Vigilância, regulamentação e problemas de abastecimento................................................ 78

A “ambição do algodão" e a retração na produção de alimentos........................................ 94

Capítulo 3. A grande Seca de 1791 na Capitania de Pernambuco e Anexas .................... 102

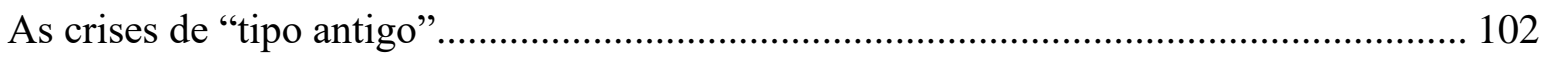

Seca, agricultura de alimentos e desabastecimento ..................................................... 106

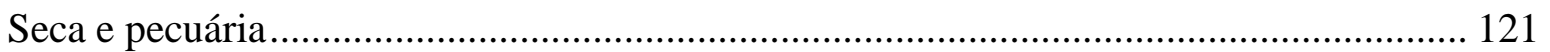

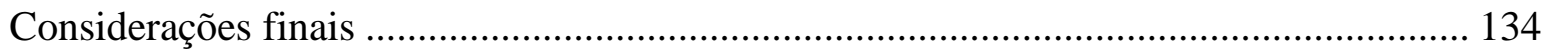

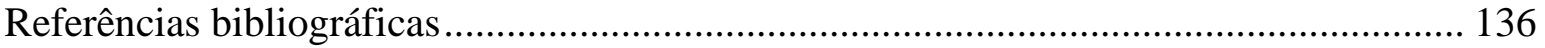

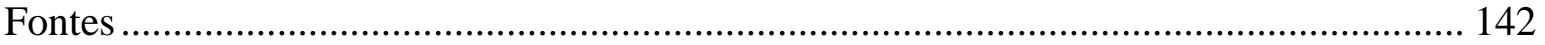




\section{Introdução}

Em 15 de janeiro de 1980, voltava a chover no Ceará, e "com fogos de artifícios, abraços e muita euforia", o cearense, principalmente o sertanejo, comemorava o que parecia ser o fim da seca. A estiagem assolava o Estado e os seus vizinhos há um ano, e as águas traziam com elas "as esperanças de um inverno", e a expectativa de uma boa safra ${ }^{1}$. Mas as chuvas não duraram muito, e no final de 1983 a seca já se estendia por $85 \%$ do território nordestino, matando diariamente cerca de cem pessoas de fome no sertão ${ }^{2}$, e com uma "população de flagelados que passa de 1 milhão de pessoas na zona rural"3. A seca só teve fim um ano depois.

Em 1782, fazia apenas quatro anos que a seca tinha chegado ao fim ${ }^{4}$ e a falta de chuvas já voltava a assombrar a capitania de Pernambuco. A fim de que voltasse logo a chover, o Bispo Dom Tomás da Encarnação ordenou que fossem feitas preces públicas nas paróquias, além de promover uma procissão de penitência, feita de pés descalços, saindo da Matriz de São Pedro. Segundo testemunhas, após o Bispo pregar quatro vezes "viram-se abrir as cataratas do céu, e chover tão copiosamente, que todos os penitentes se recolheram às suas casas completamente molhados"5. O milagre não parece ter sido duradouro, pois alguns anos depois uma nova seca voltaria a assolar a região.

Cerca de duzentos anos separam os eventos acima narrados, mas apesar da distância cronológica, eles têm algo em comum: a expectativa e a incerteza em relação à chegada das chuvas. O fenômeno da seca tem uma longa história na região. E foi seguindo os rastros dessa história, que Braudel chamou de quase imóvel, que é a do homem em relação ao meio que o cerca, que chegamos ao objeto deste trabalho ${ }^{6}$.

O principal objetivo desta dissertação foi analisar a seca que assolou as Capitanias de Pernambuco e suas anexas entre os anos de 1791 e 1793, e compreender as implicações sociais e econômicas desse fenômeno ao longo da última década do século XVIII. Em plano macro, buscou-se criar subsídios para melhor compreender as influências das variações climáticas em economias predominantemente agrícolas.

\footnotetext{
${ }^{1}$ Diário de Pernambuco. Recife, terça-feira, 15 de janeiro de 1980.

${ }^{2}$ CAMPOS, Nivalda Aparecida. A grande seca de 1979 a 1983: um estudo das ações do governo federal em duas sub-regiões do estado do Ceará (Sertão Central e Sertão dos Inhamuns). Dissertação de Mestrado. São Carlos: UFSCar/DCSo/PPGS, 2004, p.71.

${ }^{3}$ Diário de Pernambuco. Recife, segunda-feira, 17 de outubro de 1983.

${ }^{4}$ AHU - Avulsos de Pernambuco, D. 9889. Recife, 17 de outubro de 1778. Ofício do Governador da Capitania de Pernambuco, ao secretário de estado da Marinha e Ultramar, Martinho de Melo e Castro, sobre uma boa safra de açúcar no ano de 1778, devido ao tempo favorável, mas que a seca assola o sertão provocando a morte do gado. ${ }^{5}$ COSTA, Francisco Augusto Pereira. Anais Pernambucanos. v. 6. Recife: Secretaria do Interior e Justiça, 19511966, p. 339.

${ }^{6}$ BRAUDEL, Fernand. Escritos sobre a história. São Paulo: Perspectiva, 2009, p. 14-15 .
} 
O presente trabalho se inscreve no campo da história econômica, que, por sua vez, não se limita a modelos econométricos, mas que dialoga com outros campos da pesquisa ${ }^{7}$. Desta forma, procuramos estabelecer os limites ideais para o desenvolvimento de uma pesquisa que associasse investigação econômica e análise social, escrevendo "uma história econômica aberta à formalização, ao refinamento técnico e metodológico, sem abandonar ao mesmo tempo os fatores sociais" $"$.

Por tratar do papel de um fenômeno da natureza, e das suas consequências na vida humana, nossa pesquisa também estabeleceu diálogos com a história ambiental. Surgido na década de 1970, como parte de um esforço revisionista para tornar a disciplina mais inclusiva nas suas narrativas, este campo particular da história foi amplamente difundido após a publicação da edição especial dos Annales sobre "Histoire et environmement"9 e da criação da “American Society for Environmental History"10. O principal objetivo da história ambiental consiste em aprofundar o entendimento de como os seres humanos, ao longo do tempo, foram afetados pelo seu ambiente natural e, inversamente, como eles afetaram esse mesmo ambiente. Este campo da história inclui o clima e as condições meteorológicas como objetos de pesquisa, buscando compreender e analisar em que medidas eles permitiram boas ou más colheitas, forçaram os preços para baixo ou para cima e contribuíram para o crescimento ou diminuição da população ${ }^{11}$. Em termos simples, a história ambiental trata do papel e do lugar da natureza na vida humana, um propósito intimamente pertinente ao nosso trabalho.

Os fatores climáticos, suas flutuações e implicações para a sociedade, passaram a atrair maior atenção dos historiadores, particularmente, após o trabalho de Emmanuel Le Roy Ladurie sobre a História do Clima ${ }^{12}$. Em sua obra, Ladurie realizou uma cronologia das flutuações climáticas ao longo de mil anos, utilizando-se de documentos como relatos meteorológicos, crônicas, livros de receitas e despesas e indícios ambientais ${ }^{13}$. As crises e as dinâmicas do medievo e da modernidade, segundo o autor, não poderiam ser explicadas apenas por fatores econômicos e sociais, devendo-se também investigar suas possíveis origens climáticas ${ }^{14}$.

\footnotetext{
7 CARDOSO, Ciro Flamarion S.; VAINFAS, Ronaldo (orgs.). Domínios da história: ensaios de teoria e metodologia. Rio de Janeiro: Campus, 1997, p. 60-65·

${ }^{8}$ BRAUDEL, Fernand. Escritos sobre a história. São Paulo: Perspectiva, 2009, p.51.

${ }^{9}$ LADURIE, Emmanuel Le Roy. L'histoire immobile. Annales. Économies, Sociétés, Civilisations. 29 e année, N. 3( 1974) p. $673-692$.

${ }^{10}$ DRUMMOND, José Augusto. A História ambiental: temas, fontes e linhas de pesquisa. Estudos Históricos, v.4, n.8, 1991, p.177-197.

${ }^{11}$ WORSTER, Donald. Para fazer história ambiental. Estudos Históricos, v.4, n.8, 1991, p.198-200.

12 LADURIE, Emmanuel Le Roy. Historia del clima desde el año mil. Ciudad de México: Fondo de Cultura Económica, 1991 .

${ }^{13}$ Ibidem, p. 18.

${ }^{14}$ LADURIE, Emmanuel Le Roy. Historia del clima desde el año mil... op. cit, p. 18.
} 
Fernand Braudel nos adverte que nas sociedades predominantes agrícolas a qualidade ou a insuficiência das colheitas comandava toda a vida material. Nesse contexto, alterações climáticas bruscas facilmente golpeavam as sociedades ao redor do mundo, fosse através de uma pequena era glacial na França de Luís XIV ou por meio de secas calamitosas na China do século XVII. Por ser muito complexo e operar por sinuosos caminhos, o clima incidiria sobre as sociedades de formas diferentes, conforme os lugares, as culturas e as estações, mas deixando sempre clara a "fragilidade congênita dos homens ante as forças colossais da natureza" ${ }^{15}$. Para o autor, a economia do Antigo Regime era ditada pelas boas e más colheitas e sucessivos desastres poderiam pôr em movimento grandes flutuações de preços, o que constantemente levava a população à escassez e, consequentemente, à fome ${ }^{16}$.

Um dos primeiros esforços dos estudiosos que apontaram a estreita relação entre a meteorologia e as colheitas foi medir a regularidade temporal do ciclo meteorológico e compará-lo com a periodicidade das crises agrícolas. Sobre isso, em 1921, Beveridge já demonstrava, através de uma análise matemática e aritmética, a veracidade dessas correlações. Segundo o autor, os principais picos nos preços da farinha na Europa Central e até as pequenas elevações eram quase todos identificados como consequência da destruição das colheitas, atribuídos ao "clima inclemente" 17.

A respeito da Nova Espanha, Enrique Florescano demonstrou a estreita relação entre perturbações meteorológicas, más colheitas e carestia dos gêneros de primeira necessidade, em especial do milho ${ }^{18}$. Segundo o autor, as principais crises que aconteceram na colônia espanhola no século XVIII foram consequências de perdas de colheitas relacionadas com a ocorrência de secas ou geadas, e, por vezes, a combinação de mais de uma perturbação meteorológica. A crise de abastecimento que aconteceu em 1785, por exemplo, teria sido ocasionada pelo atraso das chuvas nos primeiros meses de plantio e pela sucessão de duas geadas ${ }^{19}$.

De forma semelhante, Stuart Schwartz, em trabalho mais recente, expôs como a presença de furacões perturbaram com frequência o volume das colheitas e dos rebanhos das colônias europeias no Caribe. Segundo o autor, as ilhas mais afetadas pelo fenômeno eram aquelas que se dedicavam à agricultura de exportação, com uma baixa produção voltada para o abastecimento interno. Nessas regiões, onde a produção de gêneros de primeira necessidade era

\footnotetext{
15 BRAUDEL, Fernand. Civilização Material, Economia e Capitalismo, séculos XV-XVIII. As estruturas do cotidiano. Vol. 1, São Paulo: Martins Fontes, 2005, p. 37.

${ }^{16}$ Ibidem, p. 36-38.

${ }^{17}$ BEVERIDGE, W. H. Weather and Harvest Cycles. The Economic Journal, Vol. 31, n. 124, 1921, p. 429-452.

${ }^{18}$ FLORESCANO, Henrique. Precios del maíz y crisis agrícolas en México (1708-1810). Cidade do México: Ediciones Era, 1986, p. 126.

${ }^{19}$ Idem.
} 
reduzida, os efeitos da passagem dos furacões eram mais devastadores, fazendo prontamente surgir a carestia, a escassez e a fome. Nesses momentos, as ilhas tornavam-se totalmente dependentes do abastecimento externo ${ }^{20}$.

Com relação à historiografia sobre a América portuguesa, as secas frequentemente são referidas como fenômenos com grande capacidade para desorganizar a produção colonial. Ao tratar das crises de subsistência em Salvador e no Rio de Janeiro, Francisco Carlos Teixeira apontou que as secas e a esterilidade da terra eram elementos perturbadores e desorganizadores da estrutura produtiva, já deficiente, estando fora do controle dos homens. A concorrência com as áreas voltadas para os gêneros de exportação eram fatores que comprometiam o sistema de abastecimento, levando a uma situação permanente de quase escassez. Desta forma, bastaria a chegada de um fenômeno novo para que toda a população fosse lançada na crise ${ }^{21}$. A situação se agravava quando a estiagem atingia a área abastecedora de uma região, gerando uma demanda crescente sobre a produção de alimentos das demais capitanias, influindo sobre os preços no conjunto da colônia, e levando outras áreas a escassez ${ }^{22}$.

Concomitante às ideias de Teixeira, Barickman assinala que a falta de chuvas influenciava diretamente nos preços e estoques de Salvador. Quando a seca assolava as Capitanias do Norte oriental, "negociantes de Pernambuco e Alagoas, ávidos por comprar grandes quantidades de farinha, tomavam Salvador de assalto sempre que a seca provocava escassez nos mercados"23. Sobre a relação conflituosa entre abastecimento e exportação, Barickman afirma que o crescimento da exportação, de fato, interferia no abastecimento de gêneros de primeira necessidade, contudo, por levar em consideração apenas as flutuações da economia de exportação, o modelo leva a uma visão incompleta e distorcida das crises no mercado colonial. Para o autor, ao analisar estas crises, deveria-se também considerar as condições meteorológicas, uma vez que os anos de escassez e carestia, com poucas exceções, coincidiam com secas ou invernos com chuvas muito intensas, no recôncavo e em outras regiões. Diante disso, Barickman sugeriu que as cronologias das secas deveriam ser ampliadas,

\footnotetext{
${ }^{20}$ SCHWARTZ, Stuart B. Sea of Storms: A History of Hurricanes in the Greater Caribbean from Columbus to Katrina. Princeton: University Press, p. 2014. 47- 48.

${ }^{21}$ SILVA, Francisco Carlos Teixeira da. A Morfologia da Escassez: crises de subsistência e política econômica no Brasil colônia (Salvador e Rio de Janeiro, 1680-1790). Tese de doutoramento. Niterói: UFF/ICHF/PPGHIS, 1990,p. 382.

${ }^{22}$ Ibídem, p. 258.

${ }^{23}$ BARICKMAN, B. J. Um Contraponto Baiano: Açúcar, Fumo, Mandioca e Escravidão no Recôncavo, 17801860. Rio de Janeiro: Civilização Brasileira, 2003, p. 148-149.
} 
especificando-se mais quanto sua a incidência geográfica, duração, e gravidade das estiagens, facilitando, assim, a compreensão dos seus impactos socioeconômicos ${ }^{24}$.

Seguindo os rastros dos estudos acima referenciados, a hipótese do trabalho é que, por estarem situadas em uma região de grande instabilidade climática, as capitanias de Pernambuco e suas anexas vão ter nas secas um fator periódico de desorganização da produção de gêneros de primeira necessidade. O potencial perturbador da estiagem, entretanto, estaria condicionado às circunstâncias específicas do mercado de abastecimento, em especial às tensões entre a agricultura voltada para o abastecimento e a agricultura de exportação.

Iniciada em 1791, com chuvas limitadas e irregulares, a seca se acentuou no ano seguinte, "assolando toda a zona que se estende das Alagoas ao Rio Grande do Norte, e só terminando em fins de 1793, causando em toda essa região incalculáveis prejuízos" ${ }^{25}$. Os anos sucessivos de estiagem teriam arruinado plantações e "as ribeiras dos sertões cuja fecundidade era o gado, ficaram despovoadas" ${ }^{26}$. Os seus efeitos estenderam-se até inícios do século XIX, afetando principalmente a agricultura de alimentos e a produção de carne, com consequências profundas para a população e o mercado de abastecimento. As longas estiagens eram fenômenos periódicos nas capitanias de Pernambuco e anexas, e o sistema alimentar deveria ser capaz de funcionar nessas situações adversas, entretanto, a fragilidade da estrutura produtiva em finais dos setecentos permitiu que a flutuação do clima desempenhasse um importante papel no surgimento da crise alimentar.

Espacialmente, nossa análise se deslocou pela capitania de Pernambuco e suas anexas, compreendidas aqui pela capitania da Paraíba, capitania do Rio Grande do Norte e capitania do Ceará. No período estudado, as referidas capitanias se encontravam subordinadas ao Governo de Pernambuco e foram igualmente atingidas pelas calamidades da seca.

Em linhas gerais, o primeiro capítulo é composto por três partes: inicialmente, nos centramos na compreensão das especificidades do espaço sertanejo, através da investigação do acervo produzido por religiosos, naturalistas e viajantes sobre a paisagem e o clima das regiões interioranas das capitanias de Pernambuco, Paraíba, Rio Grande do Norte e Ceará. Através dessas perspectivas, buscamos compreender as principais características do sertão do norte oriental da América portuguesa, seus aspectos físicos e particularidades sazonais. Em seguida,

\footnotetext{
${ }^{24}$ BARICKMAN, B. J. Um Contraponto Baiano... op. cit., p. 142-145.

25 COSTA, Francisco Augusto Pereira. Anais Pernambucanos. v. 1. Recife: Secretaria do Interior e Justiça, 1951 1966, p. 503.

${ }^{26}$ AHU- Avulsos de Pernambuco, D. 2354. 19 de abril de 1796. OFÍCIO do Governador da Paraíba, Brigadeiro Jerónimo José de Melo e Castro, ao Secretário de estado da Marinha e Ultramar, Luís Pinto de Sousa Coutinho, informando da calamidade que trouxe a seca, destruindo as colheitas e o gado, trazendo um número enorme de pessoas para o litoral.
} 
com o auxílio das ciências climáticas, tratamos dos fenômenos responsáveis pela recorrência de secas na região, como o El Niño. Por fim, partindo do entendimento dos períodos de estiagem como um problema de longa duração, realizamos o levantamento e analisamos as secas coloniais que afetaram a região, buscando estabelecer as suas estruturas e regularidades.

No segundo capítulo abordamos as questões conjunturais do mercado de abastecimento da capitania de Pernambuco e suas anexas em finais do século XVIII. Primeiramente, tratamos da expansão das fronteiras da pecuária, a sua importância na ocupação do território sertanejo, e como a expansão desse território corroborou para o aumento da recorrência de secas na região. Ademais, nos debruçamos sobre a produção agrícola de alimentos na Capitania Geral de Pernambuco, identificando as principais regiões abastecedoras, e os problemas encontrados pelas autoridades para garantir um aprovisionamento regular das populações durante a última década do século XVIII.

No terceiro e último capítulo, finalmente, narramos o processo da seca que se iniciou em 1791 na Capitania Geral de Pernambuco e da crise desencadeada pela mesma. Primeiramente, analisamos como a longa estiagem afetou a agricultura de alimentos, as suas implicações sociais, bem como as principais medidas tomadas pelas autoridades coloniais para conter os danos econômicos e sociais da crise de abastecimento desencadeada pelo fenômeno. As consequências da seca que assolou a Capitania Geral de Pernambuco ultrapassaram a sua própria fronteira, e no Rio de Janeiro, na Bahia e em São Paulo, os anos iniciais da década de 1790 teriam sido marcados por um forte impacto das necessidades externas de alimentos sobre a economia local. Ademais, tratamos das consequências da seca na pecuária. Além de aniquilar parte das lavouras de alimentos, a falta de chuvas devastou parte dos pastos sertanejos, desregularizando o abastecimento de carnes frescas e desorganizando as fábricas de carnes secas cearenses. A crise causada pela seca terminou favorecendo a expansão de outras zonas produtoras, como a capitania do Rio Grande do Sul.

Nosso principal fundo arquivístico concentra-se nos manuscritos depositados no Arquivo Histórico Ultramarino (AHU), digitalizados pelo Projeto Resgate Barão do Rio Branco, referentes às capitanias de Pernambuco, Paraíba, Rio Grande do Norte e Ceará. Nele se encontra farta documentação trocada entre os governadores, e a Secretaria de Estado da Marinha e Ultramar sobre a seca e problemas decorrentes da mesma. A grande maioria desses arquivos é categorizada como ofícios, no entanto, em alguns deles é possível encontrar anexos referentes a outros tipos de documentação. 
Também nos utilizamos na escrita deste trabalho da documentação do Arquivo Público Jordão Emerenciano (APEJE). De seu conjunto documental nos valemos principalmente dos fundos: Ordens Régias ${ }^{27}$, Registro de Portarias ${ }^{28}$, Ofícios do Governo ${ }^{29}$ e Correspondência para a Corte $^{30}$. Nesses conjuntos documentais encontramos medidas administrativas de governo, portarias para a população da capitania, bem como informações sobre o mercado de abastecimento.

Complementando estes acervos, também fizemos uso das documentações camarárias depositadas no Instituto Arqueológico, Histórico e Geográfico Pernambucano (IAHGP), e no Instituto Histórico e Geográfico do Rio Grande do Norte (IHGRN). Esses acervos foram essenciais para compreender as deliberações das autoridades municipais a respeito do abastecimento e diante da calamidade da seca.

${ }^{27}$ APEJE - Ordens Régias (O.R.): Volumes 19 a 24, entre 1787 e 1800.

${ }^{28}$ APEJE - Registro de portarias, provisões, editais e bandos: R.Pro 4/2. (1787-1798)

${ }^{29}$ APEJE - Ofícios do Governo (O.G.): V. 5 (1796-1793); V. 6 (1798); V. 6a (1798); V. 7 (1798-1800); V. 8 (1800-1801.

${ }^{30}$ APEJE - Correspondência para a corte (C.C.): Volumes 3 a 11, entre 1791 e 1802. 


\section{Capítulo 1. Por séculos e séculos}

Obstáculos assinalam-se como limites (envolventes, no sentido matemático) dos quais o homem e suas experiências não podem libertar-se ${ }^{31}$.

O jogo de palavras presente no título deste capítulo remete à natureza recorrente das secas nas capitanias de Pernambuco, Paraíba, Rio Grande do Norte e Ceará. O fenômeno possui uma longa história na região, onde a ocorrência de secas se encontrou intrinsicamente ligada às regiões interioranas dessas capitanias desde, pelo menos, o século XVI, repetindo-se ciclicamente ao longo de séculos. É sobre esse fenômeno, o espaço em que ele acontece e as forças da natureza por trás da sua recorrência que o presente capítulo se debruçará.

\section{Sertão e natureza nas capitanias de Pernambuco e Anexas}

O material escrito referente ao clima da América portuguesa nos primeiros séculos da sua ocupação compreendeu a produção de um conhecimento de caráter descritivo, construído através de relatos e narrativas, registros pessoais e informes governamentais de fenômenos naturais como enchentes, deslizamentos de terras e estiagens. Esses registros informavam acerca das características sazonais, como a demarcação dos períodos chuvosos e secos, a duração dos dias e das noites, direção dos ventos, dados que eram de grande importância para a navegação marítima e para os conhecimentos acerca das possibilidades de cultivo e habitação de terras ${ }^{32}$.

Por meio desses relatos os espaços eram decodificados pelo olhar dos homens em paisagens, recortes da realidade, cuja presença de rochas, matas e águas permite-se falar em paisagens naturais (predominância da natureza) e culturais (predomínio da ação humana). Entretanto, mesmo quando os elementos da natureza tiverem preponderância em sua configuração, é importante salientar que toda paisagem é firmada nas relações dos homens com os seus sentidos e memória, e, portanto, é cultural antes de ser natural ${ }^{33}$. Segundo Schama, o "próprio ato de identificar o local pressupõe nossa presença e, conosco, toda a pesada bagagem cultural que carregamos" ${ }^{34}$. A ideia de paisagem, portanto, pressupõe um objeto de percepção da imaginação humana, projetado sobre a natureza e sobre a cultura, tendo como mediador o olhar e a cognição humana.

\footnotetext{
${ }^{31}$ BRAUDEL, Fernand. Escritos sobre a história. São Paulo: Perspectiva, 2009, p. 49.

32 SANT'ANNA NETO, João Lima. História da Climatologia no Brasil: gênese e paradigmas do clima como fenômeno geográfico. Cadernos Geográficos, Florianópolis, n. 7. maio, 2004, p. 7-9.

${ }^{33}$ SCHAMA, Simon. Paisagem e Memória. op. cit, p. 17-30.

${ }^{34}$ Ibidem, p.17.
} 
A segunda metade do século XVIII foi marcada historicamente pelo desenvolvimento do pensamento científico e ilustrado, que alcançou de diferentes formas os países europeus e consequentemente suas colônias. Durante o movimento iluminista, alguns homens da ciência enxergaram nas terras do além-mar um vasto campo para as suas investigações. Naturalistas, religiosos e viajantes produziram um amplo acervo sobre as paisagens, o povo e seus costumes, e até relatórios científicos com catalogação de plantas, animais e minerais nativos destas $\operatorname{terras}^{35}$.

Mais interessante, para os nossos propósitos imediatos, neste momento buscou-se reunir descrições sobre as paisagens e as interações humanas com o meio ambiente nas regiões interioranas das capitanias de Pernambuco e Anexas. O principal objetivo foi estabelecer o quadro ambiental e humano do cenário recorrente dos objetos principais deste trabalho: a seca e as suas implicações na vida humana. Entretanto, antes de adentrar no sertão, cabe aqui uma abreviada elucidação quanto ao uso do termo e suas aplicações.

De acordo com Antônio Carlos Moraes, o sertão não deve ser compreendido como um lugar, mas sim como uma condição concedida a variados e diversificados lugares, constituindo "um símbolo imposto, em determinados contextos históricos, a determinadas condições locacionais" ${ }^{36}$. O estudioso ainda afirma que a imagem do sertão enquanto um lugar distante e isolado deve ser avaliada com cautela, uma vez que a distância seria uma noção muito variável, dependendo "das condições de transporte, numa relação onde o tempo de deslocamento emerge como critério de medida" ${ }^{37}$, assim regiões relativamente próximas poderiam ser relacionadas ao termo. Apesar das variáveis, é possível identificar a existência de particularidades em comum nas imagens do sertão, com características que compreendem a base do que pode ser definido como o imaginário do sertão. Construído e reconstruído por cronistas, missionários, padres, intelectuais e viajantes, esse imaginário extrapolaria uma delimitação espacial específica $^{38}$.

A ideia de sertão está presente no imaginário desde o século XVI, construída através de uma ideia de oposição entre as regiões colonizadas da América portuguesa, associadas ao litoral devido à própria natureza do empreendimento canavieiro, e aquelas que não se encontravam inseridas na jurisdição metropolitana ${ }^{39}$. Segundo Kalina Vanderlei:

\footnotetext{
35 VANDELLI, Domingos. Memórias de História Natural. Porto: Porto Editora, 2003, p. 10.

${ }^{36}$ MORAES, Antonio Carlos Robert. O Sertão. Terra Brasilis V. 4 - 5, 2003, p. 2.

${ }^{37}$ Idem.

${ }^{38}$ BONATO, Tiago. Viagens do Olhar: Relatos de Viajantes e a Construção do Sertão Brasileiro (1783 1822). Guarapuava: Unicentro, 2014, p. 52.

${ }^{39}$ SILVA, Kalina Vanderlei. Nas Solidões Vastas e Assustadoras...op. cit., p.44.
} 
Criou-se, assim, uma dicotomia entre o espaço considerado civilizado e aquele considerado selvagem. E até o apogeu da região mineradora no século XVIII, a área açucareira ditou o padrão de civilização para o imaginário colonial, enquanto os interiores passaram a ser designados como sertão, área desocupada que abrangia todo o continente para além da zona da cana e do litora $4^{40}$.

Desta forma, do século XVI até a primeira metade do século XVII, o sertão era uma maneira de nomear o que era desconhecido, sendo considerada uma região bravia, habitada por bárbaros hostis. O litoral açucareiro representava o lócus da civilização, enquanto que, através desta visão, a ideia de "sertão" era concebida como o "hinterland" a ser desbravado ${ }^{41}$, como o objeto de um movimento expansionista que busca incorporar aquele novo espaço.

Enquanto uma região de fronteira, os sertões das capitanias do norte do Estado do Brasil foram construídos a partir dos antigos núcleos de povoamento, constituindo-se uma área de colonização tardia em relação à faixa litorânea. Desta forma, na segunda metade do século XVII e ao longo do século XVIII, o sertão era visto como um espaço distante da zona litorânea para onde eram direcionados os colonos excedentes das regiões já povoadas, "o lugar para onde a civilização empurrava aqueles que consideravam não essenciais à produção mercantil dos seus núcleos principais" ${ }^{42}$. O espaço funcionava, assim, como "válvula de segurança" ${ }^{43}$ da sociedade açucareira.

Entretanto, o sertão ao mesmo tempo em que era inóspito, hostil, para a maioria, sob alguns aspectos, também era visto como um lugar de esperança e liberdade, para onde muitos se direcionavam em busca de refúgio e riqueza ${ }^{44}$. As poucas perspectivas de prestígio social e progresso material oportunizada aos homens livres e pobres pela sociedade do açúcar, fez do sertão um local atrativo para estes, tendo em conta a relativa facilidade de acesso à terra, seja por meio da concessão de sesmarias, ou através de arrendamentos. Além dos livres e pobres, aqueles que já haviam constituído fortuna no litoral também enxergavam o sertão como um espaço de oportunidades, propício para a diversificação dos seus negócios longe das zonas açucareiras ${ }^{45}$.

\footnotetext{
${ }^{40}$ SILVA, Kalina Vanderlei. Nas Solidões Vastas e Assustadoras...op. cit., p.112.

${ }^{41}$ GUEDES, Paulo. No íntimo do Sertão: poder político, cultura e transgressão na Capitania da Paraíba ( 17501800). Tese de doutorado. Recife: UFPE/ CFCH/ PPGH, 2013, p. 57.

${ }^{42}$ SILVA, Kalina Vanderlei. Nas Solidões Vastas e Assustadoras.... op. cit. p. 133.

${ }^{43}$ Trata-se da ideia de que a saturação das condições de existência em uma determinada área de povoamento mais antiga impele os moradores a procurarem áreas virgens, ou pelo menos pouco povoadas, que ofereciam oportunidades econômicas e de ascensão social impossíveis ou ao menos restritas, se comparadas as regiões mais antigas de povoamento. HOLANDA, Sérgio Buarque de. Caminhos e fronteiras. São Paulo: Companhia das Letras, 1994.

${ }^{44}$ AMADO, Janaína. Região, sertão, nação. Estudos Históricos, Rio de Janeiro, vol.8, n.15, 1995, p. 151.

${ }^{45}$ GUEDES, Paulo. No íntimo do Sertão... op cit, p. 70-71.
} 
Em fins do século XIX, Capistrano de Abreu foi o primeiro na historiografia brasileira a se preocupar com a construção histórica do sertão colonial ${ }^{46}$. Desde então, historiadores têm se debruçado sobre a temática, bem como sobre a origem etimológica da palavra. A origem da palavra sertão é incerta, de modo que não há consenso entre os autores que tratam do tema. Entretanto, boa parte de tais estudos definem a gênese da palavra sertão a partir de "desertão", de deserto, mas "não o deserto físico, climático, mas o espaço caracterizado por um vazio de súditos da Coroa portuguesa, apartado do litoral, afastado da zona litorânea açucareira" ${ }^{47}$. Assim, seu primeiro significado era "interior", o espaço que se encontrava longe da costa, conceito que já aparece na carta de doação da capitania de Pernambuco a Duarte Coelho ${ }^{48}$, na primeira metade do século XVI. Já em finais dos setecentos, mesmo com a colonização dos sertões das capitanias do norte do Estado do Brasil já estabelecida, o uso do termo pouco mudou. E o dicionário da língua portuguesa elaborado por Bluteau e reformado por Antônio Moraes Silva em 1789, definiu o sertão como "o interior, o coração das terras, opõe-se ao marítimo, e costa, o sertão toma-se por mato longe da costa" ${ }^{49}$.

É possível perceber, por meio das discussões bibliográficas e na pesquisa das fontes primárias, que a noção de sertão extrapola uma delimitação espacial específica ${ }^{50}$. De forma geral, o termo foi frequentemente utilizado para denominar uma série de áreas que se encontravam nas regiões interioranas das capitanias do norte, fora dos núcleos litorâneos, e que durante um bom tempo foram meras desconhecidas da maior parte dos colonos e autoridades régias, objetos de ações expansionistas, de conquista. É esse "interior” das capitanias do norte o espaço sobre o qual se pretende debruçar.

Deixando de lado o sertão enquanto categoria, serão dedicadas algumas páginas para tratar dos relatos e descrições a respeito da geografia e do clima dessa região. Uma série de áreas afastadas do litoral, interiorizadas, situadas numa região de maior instabilidade climática e mais vulneráveis à seca ${ }^{51}$, objeto principal do presente trabalho.

\footnotetext{
${ }^{46}$ ABREU, Capistrano de. Capítulos de História Colonial. Belo Horizonte: Editora Itatiaia Limitada, 2000, p. $127-193$.

${ }^{47}$ SILVA, Kalina Vanderlei. Nas Solidões Vastas e Assustadoras...Op. cit., p.44.

48 "Cortando de largo ao longo da costa, e entrarão na mesma largura pelo sertão e terra firme adentro, tanto, quanto poderem entrar e for de minha conquista". LOPES, Fatima Martins. Missões Religiosas - Índios, Colonos e Missionários na Colonização do Rio Grande do Norte. Dissertação de Mestrado. Recife: UFPE/ CFCH/ PPGH, 1999, p. 103.

${ }^{49}$ SILVA, Antônio de Moraes. Dicionário da Língua Portugueza Composto por Antônio de Moraes e Silva. Lisboa: Impressão Régia, 1831. $1^{\text {a }}$ edição de 1789, v2, p. 719.

${ }^{50}$ No período colonial "sertão" pode abarcar áreas atualmente denominadas de sertão, brejos e agreste.

${ }^{51}$ Questões a respeito da variabilidade climática da região serão mais bem tratadas no próximo tópico do presente capitulo.
} 
Uma das mais completas descrições sobre as características dos interiores das capitanias do norte da América portuguesa no século XVIII foi elaborada por Manuel Arruda Câmara, representante da geração do reformismo ilustrado da segunda metade do século XVIII. Nascido no interior da Paraíba no terceiro quartel dos setecentos, Câmara se dedicou a estudar as ciências naturais, a química e a física, formando-se médico pela Universidade de Montpellier, França, na década de $1790^{52}$. Depois de formado, regressou aos sertões onde se dedicou ao estudo do reino vegetal e mineral da região, além do aperfeiçoamento de práticas agrícolas. Para isso, realizou viagens de prospecção pelo sertão das capitanias do norte oriental, entre 1794 e 1799, elencando suas características mais gerais.

Ao abordar as divisões das estações, informação de grande relevância para a compreensão do ciclo agrícola das culturas locais, Arruda buscou apontar as particularidades climáticas do Ultramar. Segundo o autor, diferentemente do continente europeu, onde se distinguiam quatro estações constantes, ali se diferenciavam apenas o verão e o inverno, considerando "verão aquele tempo em que não chove, e inverno aquele em que as chuvas são mui abundantes, ainda que não haja frio algum" 53 .

Para além dessas observações, Arruda Câmara distinguiu outras duas características do clima das capitanias do norte, dessa vez levando em conta a "construção física da superfície do terreno" 54 . A este respeito, o naturalista apontou que nos locais em que a superfície do terreno era irregular, repleta de serras, na beira mar ou não, as chuvas eram mais abundantes, principiando mais cedo e cessando mais tarde, propiciando a existência de alagadiços e rios perenes. Desta natureza seria toda a borda do mar, principalmente do Rio Grande do Norte até o sul da Bahia, onde "em toda esta extensão, com largura de 10, 16 e 20 léguas, observa-se constantemente este clima chuvoso e úmido". Tal característica climática, batizada pelo autor de "agreste", também poderia ser observada nos sertões, nas proximidades do "cordão da serra, chamada Bruburema" ${ }^{55}$, nos brejos ${ }^{56}$. Já nas regiões de superfície regular, sem serras, onde "os campos são mais espaçosos", as chuvas seriam escassas, clima designado "mimoso" pelo estudioso $^{57}$.

\footnotetext{
52 CÂMARA, Manuel Arruda da. Obras reunidas c. 1752-1811. Coligidas e com estudo biográfico por José Antonio Gonsalves de Mello. Recife: Fundação de Cultura Cidade do Recife, 1982, p. 17-23.

${ }^{53}$ Ibidem, p. 126.

${ }^{54}$ Ibidem, p. 127.

${ }^{55}$ CÂMARA, Manuel Arruda da. Obras reunidas... Op. cit, p. 127.

${ }^{56}$ Desde o principio da ocupação das regiões interioranas, nas áreas úmidas dos brejos desenvolveram-se culturas de subsistência. ANDRADE, Manuel Correia de. A Terra e o Homem no Nordeste. São Paulo: Brasiliense, 1963, p. 146.

${ }^{57}$ CÂMARA, Manuel Arruda da. Obras reunidas... Op. cit, p. 128.
} 
Apesar da descrição de Arruda Câmara trazer a ideia de uma região regular e sem serras, a compreensão do que seria o mimoso é ampliada ao se observar a recorrência do termo para designar o próprio sertão. A este respeito, o botânico Phillipp von Luetzelburg, aponta que o termo seria uma alcunha regional para o campo das caatingas ${ }^{58}$. Tal uso pode ser observado nos relatos das viagens realizadas pelo médico e botânico britânico George Gardner aos sertões na década de 1830. Em sua passagem pelo interior do Piauí, o estudioso registrou que a região ocidental, e todo o Ceará eram referidos como uma região de mimoso pela população local, já para as áreas mais ao leste e ao centro do Piauí, o termo agreste era empregado. Segundo o autor, a vegetação das localidades de clima mimoso seria de "catinga", cujas principais características eram a resistência ao período de seca, podendo passar anos sem produzir folhagens, e a presença de folhas rígidas, cabelos, espinhos, pequenas flores e sucos leitosos em suas plantas ${ }^{59}$.

Como se pôde observar, Manuel Arruda da Câmara retratou o que seria o mimoso utilizando como referência apenas as características do relevo da região em questão, apesar do uso do termo se estender para além dessa particularidade, abrangendo outras características sertanejas, como a sua vegetação. Entretanto, Arruda Câmara também se referiu à Caatinga em si. Para o naturalista:

Catinga, em todo rigor do termo, entende-se por um terreno cheio ou coberto de uma espécie de cássia, não descrita ainda por Lineo, a que tenho dado o nome de moscata; mas lato modo também se chama catinga um terreno coberto de outro qualquer arbusto baixo, como é o mameleiro, velame, Broterea velame, e tem-se generalizado tanto este nome que até chamam hoje de catinga, em algumas partes, tudo o que não é vargem, inda que seja coberto de mata virgem ${ }^{60}$.

O dicionário Tupi de Gonçalves Dias define "caatinga" 61 como "pasto onde o mato é rasteiro, de cor esbranquiçada e a terra muito areienta: sustenta-se de flores a maior parte do tempo" ${ }^{62}$. Pelas observações de Arruda Câmara é possível perceber que a catinga havia deixado de ser apenas o terreno coberto por arbustos baixos, passando a carregar também a conotação de oposição às vargens. Dessa forma, aproxima-se mais da aridez e por isso mesmo pode ser quase sinônimo de sertão.

\footnotetext{
${ }^{58}$ LUETZELBURG, Phillipp von. Estudo botânico do Nordeste. Rio de Janeiro: Inspetoria Federal de Obras contra as secas, 1923, p. 43.

${ }^{59}$ GARDNER, George. Travels in the Interior of Brazil, Principally Through the Northern Provinces, and the Gold and Diamond Districts, During the Years1836-1841. Londres: Reeve, Benham, and Reeve, 1849, p. 184 - 185.

${ }^{60}$ CÂMARA, Manuel Arruda da. Obras reunidas... Op. cit, p.126.

${ }^{61}$ A grafia caatinga, a partir do tupi "caa", só apareceu no Brasil com o avançar do século XIX, fazendo parte do esforço dos românticos em incorporar os vocábulos tupi-guarani na língua culta. DIAS, Antônio Gonçalves. Diccionario da lingua tupy: chamada lingua geral dos indigenas do Brazil. Dresden: F.A. Brockhaus , 1858, p.33. ${ }^{62}$ Idem.
} 
O clima nos interiores das capitanias de Pernambuco, Paraíba, Rio Grande do Norte e Ceará é marcado pela contraposição entre a estação seca, presente na maior parte do ano, e alguns meses de chuva. Paradoxalmente, o prolongado período de secura, com acentuação de calor, corresponderia ao inverno meteorológico, assim o ritmo sazonal local comportava chuvas de verão e estiagem prolongada de inverno. Em seu itinerário pelos sertões do norte oriental da América portuguesa, Henry Koster observou que as chuvas da região principiavam no mês de janeiro, duravam no máximo três semanas e eram chamadas comumente de "primeiras águas"63. Após as precipitações de janeiro, o período chuvoso era "seguro até maio ou junho", depois desta época, aponta o inglês, as chuvas eram mais ou menos constantes até o fim de agosto, e de setembro até o começo do ano seguinte imperava o "tempo do estio" ${ }^{64}$. Concomitante às observações de Koster, Antônio José Paulet, ao discorrer sobre o clima da capitania do Ceará, queixou-se da dificuldade em compreender "a marcha da natureza n'este paiz", alegando que:

Aparecem ordinariamente as primeiras chuvas em janeiro que pouco duram: no equinócio de março começa o inverno, e nos fins de maio, em regra, é findo e não chove, quando o sol está na máxima distância ${ }^{65}$.

Dessa forma, o clima do sertão se caracterizava, normalmente, pela ocorrência de alguns dias de chuva no mês de janeiro, o inverno entre fevereiro e maio, momento em que as chuvas caíam com maior certeza e frequência, e o restante do ano de estio, período em que as chuvas eram mais raras. Apesar desse longo período anual sem precipitações, o sertão é apresentado como um espaço fértil e produtivo em relatos.

Referindo-se ao interior da capitania da Paraíba, entre o rio do Peixe e a Borborema, o padre Domingos Loreto Couto registrou que a região era "terra dilatada em fertilíssimos campos, vistosos oiteiros, e cortada de altíssimas serras, e por isso acomodada habitação para muitos milhares de homens" 66. Segundo o padre, após a conquista daquele território “augmentarão-se as fazendas de gados vacuns, e cavalares, crescerão as povoações, multiplicarão-se as freguesias, a cada dia se augmenta mais esse povo, riquezas, e edifícios" 67 . Citações referentes ao sertão enquanto um espaço fecundo também podem ser encontradas no relato de viagem de Henry Koster, no qual tem-se a seguinte descrição sobre o sertão da capitania do Rio Grande:

\footnotetext{
${ }^{63}$ KOSTER, Henry. Viagens ao Nordeste do Brasil. Trad. e notas L. C. Cascudo. São Paulo: Companhia Editora Nacional, 1942, p. 202

64 Idem.

${ }^{65}$ PAULET, Antônio José da Silva. Descripção Geográfica Abreviada da Capitania do Ceará. RIHGB, v.96, pt. 2, 1897. Rio de Janeiro: IHGB, 1897, p.7.

${ }^{66}$ COUTO, Domingos do Loreto. Desagravos do Brasil e glórias de Pernambuco. Recife: Fundação de

Cultura Cidade do Recife, [1757] 1981, p. 28.

${ }^{67}$ Ibidem, p. 34.
} 
Caminhamos em terras arborizadas durante uma légua, chegamos às ribas da lagoa do Piató. [...]. A lagoa do Piató mede três léguas de comprido por uma de largo. No verão, suas margens secam, mas são suficientemente capazes de plantio [...]. A fertilidade dessas margens é grande, produzindo abundância de milho, arroz, cana- de-açúcar, melões etc., e vi mesmo alguns pés de algodão plantados nas proximidades ${ }^{68}$.

A partir de junho, período em que tinha início o verão sertanejo, as águas de rios e lagoas principiavam a baixar e os sertanejos aproveitavam-se dos leitos úmidos e descobertos para cultivar suas roças, numa prática agrícola denominada de agricultura de vazante. Esse tipo de agricultura configurou-se como uma forma de adaptação dos sertanejos ao meio seco e marcado pelas irregularidades das chuvas. Os gêneros cultivados nessas condições eram de ciclo curto, uma vez que o tempo de plantio e colheita deveria acontecer durante o período da vazante, no verão, destacando-se entre eles o arroz, o feijão-branco, o jerimum, a melancia, o milho, a batata-doce ${ }^{69}$. Com a chegada das chuvas durante o inverno os níveis dos rios e lagoas se elevavam, causando a destruição das plantações cultivadas durante o período da vazante. Acerca disso, referindo-se a já citada lagoa do Piató, Koster registrou que, após estação seca, "na época do inverno, as águas se precipitam, destruindo os menores vestígios de cultivação, obrigando que essa operação se repita para a futura estação" 70 .

Os rios intermitentes ou temporários são característicos das regiões áridas ou semiáridas do mundo, dentre as quais se encontravam os sertões do norte oriental da América portuguesa. Ao contrário do que acontece em áreas mais úmidas, onde os rios sobrevivem a períodos de estio, nos sertões alguns chegavam a desaparecer em tempos prolongados de seca. Além disso, os rios sertanejos não convergiam para depressões fechadas, impedindo a formação de maiores reservatórios de água ${ }^{71}$. Sobre os cursos de água do sertão paraibano Irineo Joffly apontou que “nelles não há obstáculos naturaes que detenham as águas pluviais; nenhum acidente oferecem para um depósito d'água permanente" 72 .

Longe das várzeas era desenvolvida uma agricultura de tipo "sequeiro", onde eram plantadas palmas, e roças de mandioca ou milho, cuja produtividade ficava submetida aos bons períodos chuvosos. Dessa forma, a hidrologia da região se encontrava dependente da ocorrência das chuvas no período de inverno para manter o abastecimento necessário para os contingentes

\footnotetext{
${ }^{68}$ KOSTER, Henry. Viagens ao Nordeste do Brasil. op. cit, p 147.

${ }^{69}$ OLIVEIRA, Marcelo Almeida. As roças brasileiras, do período colonial à atualidade. Caracterização histórica e formal de uma categoria tipológica. VARIA HISTORIA, Belo Horizonte, vol.28, n 48, jul/dez, 2012, p. 767-768.

${ }^{70}$ KOSTER, Henry. Viagens ao Nordeste do Brasil. op. cit, p. 147.

${ }^{71}$ AB'SABER, A.N. Os domínios de natureza no Brasil: potencialidades paisagísticas. São Paulo:Ateliê Editorial, 2006 , p. 87.

72 JOFFILY, Irenêo. Notas sobre a Parahyba. Brasília, Thesourus, s/d, p. 185.
} 
populacionais, o gado e as lavouras. A este respeito, uma passagem da memória escrita pelo Padre Joaquim José Pereira enquanto vivia no sertão do Rio Grande na década de 1790 é bastante esclarecedora. Segundo o religioso:

É o sertão da Ribeira do Apody um continente aridíssimo e que de sorte alguma pode produzir mais que por benefício somente da chuva do céu; com ela produz a terra todos os víveres, e é capaz de criar o melhor trigo, se lho semearem, por ser a natureza do terreno barrenta e dura ${ }^{73}$.

Apesar das peculiaridades do clima e do terreno das regiões interioranas das capitanias do norte, é possível observar que os sertanejos encontraram formas de adaptar o seu cultivo e criação. Entretanto, sob a influência de diversos fenômenos climáticos ${ }^{74}$, em alguns anos podia acontecer de chover menos que o esperado durante o inverno, ou da estação de estio se prolongar, com secas que podiam durar meses ou até anos a fio. Da mesma forma, em alguns anos o inverno podia ser bastante rigoroso, com excessivas chuvas, causando cheias e danos à população ${ }^{75}$. Ambos os fenômenos eram sinônimos de problemas para a região.

A seca assolava o interior das capitanias do norte da América portuguesa de maneira praticamente periódica. Segundo Joaquim José Pereira, “este clima, pela posição do seu sertão, segundo Deus é servido, suscita àquelles povos de dez em dez anos, conforme a observação feita pelos habitantes os mais prudentes e experimentados" ${ }^{76}$. Tal incerteza com relação às chuvas fez com que os moradores da região passassem a dedicar parte do seu tempo à observação do céu, à procura de sinais de que as chuvas estavam para chegar. Observavam "com o maior interesse a barra de Natal e do Anno-bom, isto é, o modo porque a aparece a aurora de cada um desses dias; e, baseados nesse exame, dão o seu juízo a respeito do próximo inverno" 77 . A vegetação e o comportamento de alguns animais também eram interpretados como indícios premonitórios, assim "o florescer prematuro ou demorado do imbuzeiro, pão d'arco, barriguda e facheiro, o canto de algumas aves, o coaxar das rãs, a mudança de certos insectos, dão-lhes argumentos para fundamentarem a sua opinião" 78 .

Ainda com os olhos direcionados para o céu, alguns voltavam suas atenções mais aos desígnios divinos que aos corpos celestes, e nas missas de natal e "anno-bom" ficavam atentos

\footnotetext{
${ }^{73}$ PEREIRA, Joaquim José. Memória sobre a extrema fome e triste situação em que se achava o sertão da Ribeira do Apody. RIHGB, v. 20, 1857, p.180.

${ }^{74}$ Que serão aprofundados no próximo tópico do presente capítulo.

${ }^{75}$ PAULET, Antônio José da Silva. Descripção Geográfica Abreviada da Capitania do Ceará. RIHGB, v.96, 1897. Rio de Janeiro: IHGB, 1897, p. 7.

${ }^{76}$ PEREIRA, Joaquim José. Memória...op. cit, p. 176.

${ }^{77}$ Apesar de escrever em finais do século XIX, boa parte da narrativa de Joffly se refere aos anos iniciais dos oitocentos. JOFFILY, Irenêo. Notas sobre a Parahyba. op. cit., p. 176

${ }^{78}$ JOFFILY, Irenêo. Notas sobre a Parahyba. op. cit. , p. 176.
} 
ao partir das hóstias, acreditando que "se ellas dão um estalido secco, concluem em desfavor do anno; se ao contrário emitem um som surdo, apenas perceptível, têm como bom signal de inverno" 79 . Grosso modo, a seca era vista como um castigo que podia subir do inferno ou descer do céu. Sobre o fenômeno o Padre Joaquim José escreveu que:

Quem não pensará que as estações começaram depois do pecado do primeiro homem a perder o seu equilíbrio, logo que a terra perdeu igualmente o precioso nome de Paraíso Terreal, e que em castigo d'elle se estenderam as penalidades da vida de Adão à sua posteridade ${ }^{80}$.

As esperanças de um bom inverno se prolongavam até o dia de São José, 19 de março. A partir desse momento já era sabido que a possibilidade da chegada das tão esperadas e necessárias chuvas de inverno iam diminuindo cada vez mais, e "nessa imensa luta contra a natureza vê chegar o fim do prazo, passar março, entrar abril, sem que o céo mude de aspecto" ${ }^{81}$. Conforme os meses iam passando sem a ocorrência de precipitações, as reservas de água começavam a diminuir, pondo em risco as criações e exaurindo as lavouras pouco a pouco.

Como já foi visto, grande parte dos cursos de água dos sertões das capitanias do norte eram intermitentes, e no período anual de estio, quando seus níveis baixavam, suas margens eram aproveitadas para cultivos diversos. Entretanto, quando a falta de chuvas se estendia para além do período de seca estacional, seus fluxos chegavam a desaparecer, impossibilitando o acesso a água em determinadas regiões e exaurindo as lavouras das suas margens. Sobre os problemas causados pela falta das chuvas nas ribeiras, em sua Memória sobre a cultura dos algodoeiros, Arruda Câmara queixava-se de que as grandes secas de 1791 o tinham feito perder "uma grande plantação do algodão que estabeleci nas margens do Rio Paraíba do Norte" 82.

O esgotamento fluvial em períodos de estiagens também não passou despercebido por Koster. Em sua passagem por um trecho do rio Ceará-Mirím na capitania do Rio Grande do Norte durante a seca de 1810, o viajante escreveu que naquele momento "o curso do rio só era marcado pela depressão de seu leito e todo solo vizinho era um areal solto, sem vegetação alguma e em tudo semelhante ao que se encontra no canal do rio" ${ }^{83}$. Após realizar parte do percurso sem avistar reservas de água, o inglês acrescentou que havia encontrado "um poço d'água salobra, aberto no mesmo leito do rio" ${ }^{84}$.

\footnotetext{
${ }^{79}$ JOFFILY, Irenêo. Notas sobre a Parahyba. op. cit. , p. 175.

${ }^{80}$ PEREIRA, Joaquim José. Memória...op. cit, p.176.

${ }^{81}$ JOFFILY, Irenêo. Notas sobre a Parahyba. op. cit., p. 181.

${ }^{82}$ CÂMARA, Manuel Arruda da. Obras reunidas...op cit, p. 108.

${ }^{83}$ KOSTER, Henry. Viagens ao Nordeste do Brasil. op. cit, p. 123.

${ }^{84}$ Idem.
} 
Segundo Ab' Saber, em áreas úmidas os rios conseguem sobreviver aos longos períodos de estiagem devido à carga de água economizada nos lençóis superficiais, já em regiões semiáridas esse lençol afunda, ressecando-se, e o fluxo dos rios passa a alimentar esse lençol, secando superficialmente e dificultando o acesso a água ${ }^{85}$. Em períodos como esses, os sertanejos utilizavam-se de algumas estratégias para ter acesso à quantidade mínima de água para o seu sustento, dos seus familiares e animais. Testemunha da grande seca que ocorreu entre 1791 e 1793, o padre Joaquim José, ao escrever sobre a situação da Ribeira do Apody diante de longo período sem chuvas, relatou uma das formas encontradas para se ter acesso à água:

Para ponderar mais com atenção sobre este clima basta ver que nele as suas aguas andam subterrâneas, e os animais e a gente não as podem beber senão depois que a terra é aberta com as ferramentas rusticas; e ainda assim mesmo ela chega a faltar em alguns lugares, dos quais são obrigados a retirar-se de todo para irem refrigerar-se em outro lugar; porém em uma seca, como a de que tratamos, e em outras, falta a agua em quase todos os sertões semelhantes ao do Apody ${ }^{86}$.

A diminuição drástica das reservas de água podia ser parcialmente remediada por meio de poços. Apesar de não serem suficientes para trazer fertilidade ao terreno, que sem a ocorrência de chuvas não produzia lavouras e pasto suficiente para o gado, esses buracos cavados nas proximidades dos leitos secos eram capazes de garantir a sobrevivência das pessoas e de alguns animais por um período.

Nessas regiões os poços são feitos geralmente cavando-se um buraco de dois a três pés, até que a água apareça. Si a pessoa é um tais que ama o asseio, rodeia o poço com uma pequena cerca, mas, na maioria dos casos o poço fica livre e o gado emporcalha quando vem beber. Esses poços são chamado "cacimbas" 87.

As cacimbas acima descritas nada mais eram do que poços artesanais usados para armazenar água. Por serem profundos e possuírem uma largura pequena na superfície, o contato do sol com a superfície da água ficava limitado àquela porção, o que diminuía a evapotranspiração da água, configurando como uma das mais eficientes estratégias realizada pelos sertanejos para armazenar água nos períodos de seca. Em nota à descrição feita por Koster, Câmara Cascudo revela:

As cacimbas raramente ficam cercadas e a razão não é o desamor ao asseio, virtude que Koster exalta. Trata-se de uma tradição que denuncia o uso dos pastos em comum, livres de defesa e, consequentemente, as utilidades adquiridas serviriam a todos. A cacimba cercada é índice de egoísmo e vendoas agora, já sabemos que o proprietário é civilizado ou a época é de secas, justificando a proibição momentânea pela regular serventia de todo o gado em

\footnotetext{
${ }^{85}$ AB’SABER, A.N. Os domínios de natureza no Brasil: potencialidades paisagísticas. op. cit., p. 87-88.

${ }^{86}$ PEREIRA, Joaquim José. Memória... op. cit. p, 180.

${ }^{87}$ KOSTER, Henry. Viagens ao Nordeste do Brasil. op. cit, p. 120.
} 
certas horas. A cacimba, cavada e deixada livre, não poderia estar cercada por se tornar inútil ou exigiria um vaqueiro para dar de beber aos animais. Um ditado sertanejo querendo expressar um avarento, diz apenas: - aquilo é homem de cacimba fechada ${ }^{88}$.

Dependendo da severidade da seca, ter acesso a esses pequenos reservatórios de água pelo sertão poderia significar uma questão de vida ou morte. Também são encontradas referências às cacimbas na obra de Spix e Martius, onde é ressaltado o gosto salgado da água oriunda dos poços, gosto este também experimentado por Koster após passar um longo período sem acesso à água: "Pela manhã, a nove horas, com grande alegria nossa, descobrimos um poço(...). Como ordinariamente, o poço era imundo e salobro, porém não esquecerei jamais com que delícia servi os primeiros goles" ${ }^{\Perp 9}$. Assim, em períodos de seca as viagens iam seguindo o leito dos rios, de cacimba em cacimba.

Mesmo com algumas estratégias utilizadas com o intuito de reduzir as consequências imediatas da falta de chuvas na região, a sua continuidade ia paulatinamente causando a destruição das plantações e do gado, afetando principalmente a alimentação dos sertanejos. Contudo, o temor diante da seca era contrabalanceado pela esperança de uma boa chuva que de um momento para o outro poderia aparecer para melhorar a situação. $\mathrm{O}$ cair das chuvas era capaz de mudar rapidamente o aspecto árido do sertão.

Em período de secas existem nuvens esparsas, mas não chove, e os sertões funcionam como espécies de "semidesertos nublados". E, de repente, quando as chuvas voltam a cair, “árvores e arbustos de folhas miúdas e múltiplos espinhos protetores entremeados por cactáceas empoeiradas, tudo reverdece" ${ }^{90}$. Isso acontece graças à combinação das águas depositadas na superfície do solo com a grande luminosidade dos sertões, que atuam na rápida restauração da funcionalidade da fotossíntese. Em pleno ano de seca Henry Koster relatou esse fenômeno, mostrando a transformação gradual do ambiente com a chegada das chuvas:

Tínhamos sofrido vários aguaceiros inopinados, nos dias anteriores e, mesmo não sendo fortes, a relva começava a brotar em vários lugares. A rapidez da vegetação no Brasil é assombrosa. Num bom terreno, caindo chuva à tarde, no outro dia já existe um leve matiz de verde; continuando as chuvas, os renovos da relva medirão uma polegada, e, no terceiro dia, serão suficientemente longos para que o gado possa pastar ${ }^{91}$.

A chegada das chuvas mudava drasticamente a paisagem do sertão, reverdecendo sua vegetação e recompondo os fluxos dos rios, e mesmo que não garantisse uma reparação

\footnotetext{
${ }^{88}$ CASCUDO, Câmara. In: KOSTER, Henry. Viagens ao Nordeste do Brasil... op. cit, p. 144.

${ }^{89}$ KOSTER, Henry. Viagens ao Nordeste do Brasil... op. cit, p. 128.

${ }^{90}$ AB'SABER, A.N. Os domínios de natureza no Brasil... op. cit., p. 85.

${ }^{91}$ KOSTER, Henry. Viagens ao Nordeste do Brasil... op. cit, p. 190.
} 
imediata aos danos causados pela seca, como o reestabelecimento de lavouras e das criações, era uma oportunidade de recomeço. Entretanto, com certa frequência, essas chuvas eram torrenciais, que caíam em grande quantidade em um curto período, também causando estragos.

Essas chuvas torrenciais, extensivas a imensas áreas do sertão, podiam provocar o aumento excessivo do volume de água de alguns trechos de rio ocasionando transbordamentos potencialmente catastróficos, afetando plantações e habitações. Tratando da capacidade de destruição das chuvas excessivas, Joffly advertiu que nos leitos dos rios "de massapê impermeável, de rara vegetação ou despidas dela, as águas seguem incontinente pelos regos ou sulcos, dão logo nos riacho e rios, produzindo, quando são fortes, as grandes cheias, verdadeiras avalanches, que tudo destroem em sua passagem" 92 .

O clima do interior das capitanias de Pernambuco e anexas era marcado pela incerteza diante de dois fenômenos opostos, a ausência das chuvas ou o seu excesso. Após vivenciar períodos de seca e de chuvas torrenciais, um viajante concluiu que "o desconforto é causado por cada um dos extremos, mas a lembrança apreensiva da falta d'agua é maior nos efeitos desagradáveis que sua imoderada abundância, chuvas pesadas e terras alagadas" 93 .

\section{Climas de estiagem}

A tarefa dos historiadores ambientais é geralmente interdisciplinar, já que são necessários tanto a percepção quanto o conhecimento das condições ambientais em um dado momento e lugar ${ }^{94}$.

Para além da história econômica e social, o presente trabalho trata do papel da natureza na vida humana, e por "natureza" designa-se o mundo não humano, o mundo que nós não criamos originalmente. Ao lidar com acontecimentos relacionados ao ciclo hidrológico, por exemplo, "estamos diante de energias autônomas que não derivam de nós", mas que estimulam reações, defesas e ambições humanas ${ }^{95}$. A partir dessa perspectiva, buscando compreender os fenômenos por trás da instabilidade climática da região estudada, nesse momento, foi estabelecido um diálogo interdisciplinar com as ciências climáticas. Aqui a principal pergunta a ser feita e a ser respondida é: o que causou os distúrbios dos sistemas naturais nos interiores das capitanias de Pernambuco e Anexas?

\footnotetext{
92 JOFFILY, Irenêo. Notas sobre a Parahyba. op. cit., p. 185.

${ }^{93}$ KOSTER, Henry. Viagens ao Nordeste do Brasil. op. cit, p. 180.

94 WINIWATER, Verena. "Abordagens sobre a história ambiental: um guia de campo para seus conceitos," Abordagens Geográficas, v.1, n. 1, 2010, p. 5.

${ }^{95}$ WORSTER, Donald. Para fazer história ambiental. Estudos Históricos, v.4, n.8, 1991, p. 202-205.
} 
O território que compreendia os sertões das capitanias do norte da América portuguesa é formado por uma região semiárida, caracterizada pelo regime de chuvas definido pela escassez, irregularidade e concentração das precipitações pluviométricas num curto intervalo de tempo ${ }^{96}$. A região se encontra entre 1 e 18 graus de latitude sul, o que poderia constituir um fator de forte influência para um bom volume e distribuição de chuva, entretanto, as precipitações médias do interior regional variam entre 500 a $800 \mathrm{~mm} / \mathrm{ano}^{97}$. Se comparados com as precipitações médias de alguns países europeus, como a Alemanha e a França, esses valores poderiam ser considerados ainda elevados, no entanto, o balanço hídrico do semiárido é altamente deficitário graças às elevadas taxas de evaporação, reflexo dos altos índices de insolação que incidem sobre a região ${ }^{98}$.

As chuvas do semiárido apresentam grande variabilidade espacial e temporal, onde anos de secas e chuvas abundantes se alternam de formas erráticas. Entretanto, segundo Marengo,

a ocorrência de chuvas, por si só, não garante que as culturas de subsistência de sequeiro serão bem sucedidas, e um veranico ou período seco dentro da quadra chuvosa pode ter impactos bastante adversos à agricultura da região. No semiárido é frequente a ocorrência de períodos secos durante a estação chuvosa que, dependendo da intensidade e duração, provocam fortes danos nas culturas de subsistência ${ }^{99}$.

Os climas do sertão e do agreste são marcados por sua extrema flutuação, com uma variabilidade pluviométrica de até $40 \%$. Além disso, mesmo em um ano considerado normal cerca de $80 \%$ da precipitação se concentram durante a estação chuvosa ${ }^{100}$, chamada de inverno pelos seus habitantes. Quando da ocorrência de uma rigorosa seca, os níveis de precipitação anual e os padrões de distribuição de chuvas durante o período chuvoso ficam muito distantes dos observados em anos de inverno normal, pondo em risco todo o calendário agrícola.

A recorrência dos períodos de estiagem, bem como seus consequentes prejuízos socioeconômicos, levou à procura das causas de tais eventos. Em 1928, Gilbert Walker estabeleceu que a precipitação irregular do sertão era resultado de alguma influência exercida

\footnotetext{
96 SILVA. Roberto Marinho da. Entre o combate à seca e a convivência com o semi-árido: transições paradigmáticas e sustentabilidade do desenvolvimento. Tese de doutoramento. Brasília: UnB/ CDS/PPGD, 2006, p 16-17.

${ }^{97}$ GIRẦ, Osvaldo. Reconstrução do Clima no Nordeste Brasileiro. Finisterra, XLVII, 93, 2012, p. 37.

98 Segundo Renato Duarte, em dois anos de seca, açudes com profundidade inferior a seis metros secam completamente. DUARTE, Renato. Do desastre natural à calamidade pública. A seca de 1998-1999. Fortaleza: Banco do Nordeste, 2002, p. 22.

${ }^{99}$ MARENGO, J. Vulnerabilidade, impactos e adaptação à mudança do clima no semi-árido do Brasil. Parcerias Estratégicas, v.27, 2008, p. 149-150.

${ }^{100}$ KOUSKY, Vernon. Frontal influences on Northeast Brazil. Monthly Weather Review. v107, 1979, p. 11401153.
} 
pela Oscilação do El Niño, e partir dessa descoberta, chegou até a propor uma fórmula estatística ligando a incidência de seca e fome no Ceará às fases da Oscilação Sul do El Niño ${ }^{101}$.

O fenômeno EL Niño é resultado de uma interação entre a atmosfera e os oceanos, que leva ao aquecimento anómalo das águas do oceano Pacífico Tropical, habitualmente frias junto à costa oeste da américa do sul, provocando flutuações e anomalias climáticas. A conexão entre esse fenômeno e a falta de chuvas no sertão funciona da seguinte maneira: a chuva do sertão se concentra nos meses (março/abril), momento em que a Zona de Convergência Intertropical (ZCIT), formada por um cinturão de densas nuvens que circundam a faixa equatorial terrestre, atinge sua posição mais meridional. Durante as fases intensas do El Niño, uma zona de alta pressão atlântica anomalamente forte fica instalada ao longo da costa do Brasil, bloqueando o deslocamento da Zona de Convergência Intertropical para o sul, sua posição habitual de produzir chuvas no sertão ${ }^{102}$. Por outro lado, o fenômeno de características opostas ao El Niño, conhecido como La Niña, é caracterizado por um esfriamento anormal nas águas superficiais do Oceano Pacífico, com anomalias climáticas contrárias àquelas observadas em anos de El Niño, provocando o fenômeno das cheias nos sertões.

Quando os períodos de estiagem ocorrem durante apenas um verão, são consideradas simplesmente como secas resultantes de uma atuação incipiente, dos sistemas atmosféricos atuantes na estação, oriunda de um fenômeno El Niño considerado fraco. Entretanto, quando a baixa precipitação se propaga desde o verão anterior ao próximo, a estiagem prolongada (que excede um ano, e pode chegar a mais de três anos) é creditada às influências de um fenômeno El Niño de atuação moderada à forte ${ }^{103}$. De forma geral, os episódios de El Niño começam a se desenvolver em meados do ano, atingindo a sua máxima intensidade ao final daquele mesmo ano, se dissipando cerca de seis meses depois, e causando impactos sobre a precipitação sertaneja principalmente na quadra chuvosa (de fevereiro a maio), inibindo-a ${ }^{104}$. Os registros

\footnotetext{
101 WALKER, Gilbert. Ceará (Brazil) Famines and the General Air Moviment. Beiträge zur Physik der freien Atmosphäre, 107, 1979, p. 88-93.

102 CAVIEDES, César N. El Niño in history: storming through the ages. Gainesville: University Press of florida, 2001, p. 102-103.

103 MARENGO, José; ALVES, Lincoln M ; BESERRA, Elder. ; LACERDA, Francinete . Variabilidade e mudanças climáticas no semiárido brasileiro. In: Salomão de Sousa Medeiros, Hans Raj Gheyi, Carlos de Oliveira Galvão, Vital Pedro da Silva Paz. (Org.). Recursos Hidricos e, Regiões Aridas e Semi Aridas. Campina Grande: INSA, 2011, p. 390-391.

104 MARENGO, José; ALVES, Lincoln M ; BESERRA, Elder. ; LACERDA, Francinete . Variabilidade e mudanças climáticas no semiárido brasileiro. In: Salomão de Sousa Medeiros, Hans Raj Gheyi, Carlos de Oliveira Galvão, Vital Pedro da Silva Paz. (Org.). Recursos Hidricos e, Regiões Aridas e Semi Aridas. Campina Grande: INSA, 2011, p. 390-391.
} 
históricos pluviométricos de fortaleza mostram que os dez períodos mais secos, durante a quadra chuvosa, foram todos sincronizados com fortes fenômenos El Niño ${ }^{105}$.

Embora a região de origem do fenômeno seja um imenso e obscuro deserto oceânico, com apenas um pequeno número de ilhas habitadas, sua área de influência historicamente inclui antigas áreas interioranas agrárias, densamente ocupadas, atingindo as mesmas muitas vezes de forma simultânea. Ao longo da história, para além dos interiores da região Nordeste do Brasil, o El Niño tem provocado alterações de precipitações atmosféricas em várias partes do globo, como grandes secas na Índia, norte da China, Austrália, costa oeste da África, bem como cheias no Peru e no meio oeste dos Estados Unidos ${ }^{106}$.

Em seu estudo que versa sobre a interação entre os processos climáticos e econômicos durante o Período Vitoriano, Mike Davis configurou o fenômeno da ENSO (El Niño-Southern Oscillation) como a mais importante fonte de variabilidade do clima global. Segundo o estudioso, "nenhuma outra perturbação ambiental interanual tem tão grande amplitude ou impacto de longo alcance, capazes de causar penúria a um quarto da raça humana em cinco continentes" 107.

Apesar da existência de certos padrões nas suas recorrências e teleconexões, é importante salientar que cada de El Niño representa um fenômeno histórico distinto, não existindo fenômenos iguais em termos de gênesis, ciclo e mortalidade. Ademais, diante da multiplicidade de modos de interação entre os regimes de circulação da ENSO e outras variações periódicas, seus efeitos podem ser bastante complexos.

Mesmo ocorrendo em períodos pouco regulares, episódios de El Niño podem ser caracterizados como cíclicos, reaparecendo, em média, em intervalos de dois a sete anos, com variações de intensidade $^{108}$. Quanto maior a intensidade do fenômeno, maior a probabilidade de causar grandes anomalias nas precipitações das áreas que se encontram sob a sua influência. Em relação à sua influência na precipitação do sertão, cruzando os dados de relatos, documentos históricos dos século XVI ao XVIII e trabalhos que tratam das secas dos séculos XIX e XX

\footnotetext{
105 TEÓFILO, Rodolfo. A Seca de 1915. Fortaleza: Edições UFC, 1980, p. 129-130.

106 DIAZ, Henry F.; MARKGRAF, Vera. El Niño Historical and Paleoclimatic Aspects of the Southern Oscillation. Londres: Cambridge University Press, 1993, p. $9-11$.

${ }^{107}$ DAVIS, Mike. Holocaustos Coloniais - Clima, Fome e Imperialismo na Formação do Terceiro Mundo. Rio de Janeiro: Record, 2002, p. 249.

${ }^{108}$ MARENGO, José; ALVES, Lincoln M ; BESERRA, Elder. ; LACERDA, Francinete . op, cit, p. 391
} 
com os anos de ocorrência do fenômeno ${ }^{109}$, é possível constatar que trinta secas coincidem com anos de El Niño, o que confirma que a simultaneidade dos eventos é frequente (Quadro 1).

\section{Quadro 1 - Secas coincidentes com anos de EI Niño}

\begin{tabular}{|l|l|l|l|l|}
\hline Século XVII & Século XVIII & Século XIX & Século XX & Século XXI \\
\hline $1603(\mathrm{M})$ & $1722-1724(\mathrm{~F})$ & $1802-1804(\mathrm{~F})$ & $1900(\mathrm{~F})$ & $2015(\mathrm{~F})$ \\
\hline $1614(\mathrm{~F})$ & $1736-1737(\mathrm{~F})$ & $1810(\mathrm{M})$ & $1902(\mathrm{M})$ & \\
\hline $1692(\mathrm{~F})$ & $1744-1746(\mathrm{M})$ & $1824-1825(\mathrm{M})$ & $1915(\mathrm{M})$ & \\
\hline & $1754(\mathrm{M})$ & $1844-1846(\mathrm{M})$ & $1919(\mathrm{M})$ & \\
\hline & $1775-1778(\mathrm{~F})$ & $1877-1879(\mathrm{MF})$ & $1932(\mathrm{~F})$ & \\
\hline & $1791-1793(\mathrm{MF})$ & $1888-1889(\mathrm{M})$ & $1941-1944(\mathrm{~F})$ & \\
\hline & & & $1951-1952(\mathrm{M})$ & \\
\hline & & & $1958(\mathrm{~F})$ & \\
\hline & & & $1970(\mathrm{M})$ & \\
\hline & & & $1979-1983(\mathrm{MF})$ & \\
\hline & & & $1993-1994(\mathrm{~F})$ & \\
\hline
\end{tabular}

Legenda: M: El Niño de Intensidade moderada. F: El Niño de Intensidade Forte. MF: El niño de intensidade Muito Forte. Fontes: ALVES, Joaquim. História das secas. Mossoró: Fundação Guimarães Duque/ ESAM, 1982; COSTA, Francisco Augusto Pereira. Anais Pernambucanos. v. 6. Recife: Secretaria do Interior e Justiça, 19511966, p. 339; AHU - Avulsos de Pernambuco, D. 2705; AHU - Avulsos da Paraíba, D. 416; AHU - Avulsos da Paraíba, D. 796; AHU - Avulsos do Ceará, D. 325; AHU- Avulsos de Pernambuco, D. 6306; AHU - Avulsos de Pernambuco, D. 9081; AHU - Avulsos de Pernambuco, D. 9889; AHU - Avulsos (BG), D. 2345; AHU - Avulsos da Paraíba, D. 2801; DIAZ, Henry F.; MARKGRAF, Vera. El Niño Historical and Paleoclimatic Aspects of the Southern Oscillation. Londres: Cambridge University Press, 1993. MARENGO, José.; TORRES, Roger.; ALVES, Lincoln. Drought in Northeast Brazil - past, presente and future. Theoretical and Applied Climatology, v.20, 2016.

Os registros dos anos de 1791, 1877, 1979 e 1998, em especial, chamam a atenção, pois foram anos de secas coincidentes com eventos El Niño de Intensidade muito forte. A coincidência dos eventos, sem dúvidas, contribuiu para a longa duração dessas estiagens e o potencial das mesmas em atingir grandes extensões geográficas, desencadeando graves desdobramentos nas regiões interioranas do atual Nordeste brasileiro.

Os anos de 1877 a 1879 , por exemplo, foram marcados pelo acontecimento da que foi considerada a maior seca do século XIX, consequência do episódio da ENSO de 1876, durante a qual a falta de abastecimento de água e alimentos impeliu milhares de sertanejos a abandonarem seus domicílios no sertão em direção ao litoral ${ }^{110}$. Simultaneamente, o mesmo El

109 DIAZ, Henry F.; MARKGRAF, Vera. El Niño Historical and Paleoclimatic Aspects of the Southern Oscillation. Londres: Cambridge University Press, 1993. ; TEMPO DE CHUVA - Estudos Climáticos e de Previsão para o Ceará e Nordeste Setentrional. 1a. ed. Fortaleza-Ceará: Editora ABC, 2001.

110 SOUSA, José Weyne de Freitas. Política e Seca no Ceará (1877-1915): um projeto de progresso para o Norte (1869 - 1905). Tese de doutorado. São Paulo: USP/FFLCH/PPGHE, 2009, p. 52. 
Nino foi responsável por secas na região central da China, no norte da Índia ${ }^{111}$, e nas regiões produtoras de grãos no México, que perderam a maior parte da produção anual ${ }^{112}$.

Já a seca que se desenrolou entre os anos de 1791 e 1793, provocando uma situação de carestia, penúria e fome, teria tido como agente causador o El Niño mais intenso dos setecentos, iniciado um ano antes da estiagem. As teleconexões do mesmo fenômeno também causaram distúrbios nas precipitações indianas ${ }^{113}$ e em Angola, que sofreu com a seca mais severa do seu território no século XVIII, momento que, segundo Miller, foi de pico na exportação de escravos de Luanda e Benguela, incrementado principalmente por refugiados da seca que buscavam refugiar-se no litoral ${ }^{114}$.

Como se pôde observar, uma dinâmica climática de influência global se encontrou por trás de muitas das grandes secas que aconteceram nos sertões ao longo da história. Apesar da sua ocorrência secular, foi a partir do século XVIII que as estiagens passaram a ter maiores consequências sociais, graças crescimento da população ligada às atividades agrícolas e pecuárias, que passaram a se estabelecer em regiões climaticamente mais instáveis e suscetíveis à falta de chuvas. Neste contexto, onde se concentra ainda uma sociedade marcadamente agrária, com o uso de práticas mais rudimentares de cultivo e pecuária, o clima e seus ritmos são fundamentais para a compreensão da organização do espaço e do social. Nesse momento as secas passam a entrar de forma permanente nos relatos de cronistas e nos documentos administrativos, enfatizando sempre a calamidade da fome e os prejuízos causados pelo "flagelo da natureza".

\section{Uma cronologia de intempéries}

Será verossímil que em todos os dias do homem, e em todos os séculos do mundo se experimentem calamidades, e estas se renovem sempre, ainda quando as estações se observarem de algum modo bem reguladas em outros lugares ${ }^{115}$.

\footnotetext{
${ }^{111}$ DAVIS, Mike. Holocaustos Coloniais - Clima, Fome e Imperialismo na Formação do Terceiro Mundo. Rio de Janeiro: Record, 2002, p. $255-261$.

${ }^{112}$ CAVIEDES, César N. El Niño in history: storming through the ages. Gainesville: University Press of florida, 2001, p 143.

${ }^{113}$ DAVIS, Mike. Holocaustos Coloniais. op. cit. p, 255-257.

${ }^{114}$ MILLER, Joseph C. The Significance of Drought, Disease and Famine in the Agriculturally Marginal Zones of West-Central. Journal of African History, 23, 1982, p. 29-31.

115 PEREIRA, Joaquim José. Memória...op. cit, p. 179.
} 
Um dos primeiros relatos de secas na América portuguesa deve-se a Fernão Cardim, que enquanto Jesuíta frequentou as capitanias da Bahia e Pernambuco, onde se encontrava quando, em 1583, teria havido uma estiagem tão grande que as "fazendas de canaviais e mandioca muitas se secaram". Segundo Cardim, a falta de chuvas teria provocado uma grande escassez de alimentos no sertão pernambucano, afetando principalmente os indígenas que "desceram do sertão apertados pela fome, socorrendo-se aos brancos quatro ou cinco mil índios" ${ }^{116}$. Crises climáticas como a de 1583 parecem ter afligido os indígenas desde antes da chegada dos portugueses, que além de descerem para o litoral em busca de refúgio em momentos críticos, encontravam outras formas de lidar com a ausência de chuvas na região. Em seu "Tratado Descritivo do Brasil em 1587”, Gabriel Soares e Souza não registrou a ocorrência de secas, entretanto, ao descrever as plantas alimentícias da região, registrou o uso de algumas delas como alimento e alívio em períodos de seca e escassez. Como o embú, fruta encontrada

pelo sertão, no mato que se chama càtinga, que está pelo menos afastado vinte léguas do mar, que é terra seca, de pouca água, onde a natureza criou estas árvores para remédio da sede que os índios por ali passam(...)e que a gente que anda pelo sertão mata a sede onde não acha água para beber, e mata a fome comendo esta raiz, que é mui sadia ${ }^{117}$.

Tais artimanhas utilizadas pelos indígenas para escapar da fome e da sede em tempos de águas escassas teriam sido incorporadas pelo europeu em seu cotidiano e andanças pelos sertões. Além do embú, a palmeira ouricurí também era fonte de sustento em momentos de crises, pois era "cheio de um miolo alvo e solto como o cuscuz", que era retirado e cozido, considerado um mantimento sadio "substancial e proveitoso aos que andam pelo sertão" 118 .

No decorrer do século XVII ocorreram quatro secas, em 1603, 1614, 1645 e $1692^{119}$, que afetaram principalmente as capitanias de Pernambuco, Paraíba, Rio Grande do Norte e Ceará. Segundo registros de Pereira da Costa, a seca de 1645 foi rigorosa por ser no meio do verão, da qual teriam sobrevindo doenças contagiosas de "catarros, pontadas e febres malignas, das quais morreu muita gente por toda capitania". O contágio teria se alastrado para o Recife, perdurando por mais um ano, fazendo grande número de vítimas principalmente entre os Holandeses ${ }^{120}$. Já a última estiagem do século, ocasionou prejuízos principalmente aos

\footnotetext{
${ }^{116}$ CARDIM, Fernão. Tratado da terra e gente do Brasil. São Paulo: Companhia EditoraNacional/MEC, 1978, p. 199.

${ }^{117}$ SOUZA, Gabriel Soares de. Tratado descritivo do Brasil em 1587. Belo Horizonte: Itatiaia, 2000, p. 192.

118 Idem.

119 ALVES, Joaquim. História das secas. Mossoró: Fundação Guimarães Duque/ ESAM, 1982, p. 24.

${ }^{120}$ COSTA, Francisco Augusto Pereira. Anais Pernambucanos. v. 1. Recife: Secretaria do Interior e Justiça, 19511966, p. 503.
} 
rebanhos e as populações interioranas ${ }^{121}$, "tendo morrido à fome na capitania da Paraíba inúmeros escravos de ordens religiosas que não puderam adquirir viveres para sua manutenção" 122. Os relatos sobre as faltas de chuvas ao longo dos seiscentos são escassos e pontuais, impossibilitando uma análise mais profunda sobre as mesmas. Foi só no século seguinte que os registros sobre estiagens se tornaram mais frequentes e completos, graças ao alargamento das fronteiras agrícolas e pecuárias, a partir da ocupação e fixação de contingentes populacionais em regiões interioranas, mais suscetíveis à instabilidade climática.

Tentativas de adentrar os interiores continentais já haviam sido realizadas desde o século XVI, sem avançarem muito em direção ao oeste. Foi só a partir da segunda metade dos seiscentos, com a restauração das capitanias do norte pela jurisdição portuguesa que o interesse na região foi se tornando mais forte ${ }^{123}$. A justificativa para a expansão estaria, segundo Puntoni, nas dificuldades da situação econômica da colônia após a expulsão dos holandeses em 1654, com fatores internos que penalizaram as atividades produtivas, como epidemias, secas, e, principalmente, fatores externos, como a concorrência interimperial, a partir do crescimento da produção antilhana, e a inflação dos preços dos escravos ${ }^{124}$. Assim, a Coroa buscava alternativas para repor os prejuízos no trato colonial, e ao lado do esforço da recuperação da economia açucareira, a empresa colonial voltou-se para a expansão territorial em direção ao interior da América portuguesa. O processo de ocupação das regiões mais interioranas foi, então, dinamizado pelo incremento do povoamento e diversificação das atividades produtivas. E nos primeiros decênios do século XVIII, o norte da colônia já estava ponteado de fazendas de gado, onde, segundo descrição de Antonil, o sertão pernambucano totalizava oitocentos currais ${ }^{125}$.

Em 1712, o capitão-mor da Paraíba, João da Maia da Gama, escrevia ao Rei para informar da estiagem que atingia a capitania há quase dois anos. Iniciada em 1710, a seca teria, já no ano seguinte, levado a morte "muitos milhares de gado nesta capitania, pois houve fazenda de 3 mil cabeças que não ficou mais de 600". A seca parece não ter se restringido às regiões mais interioranas, alcançando os canaviais que "arderam e as plantas secaram", sendo, segundo Maia da Gama, a razão e causa de não ter havido lances no contrato do açúcar, que ficou "andando meses na Praça" ${ }^{126}$. Apesar dos problemas apontados pela autoridade local, a falta

\footnotetext{
${ }^{121}$ JOFFILY, Irenêo. Notas sobre a Parahyba. Brasília, Thesourus, s/d, p. 90.

122 ALVES, Joaquim. op cit, p. 28.

${ }^{123}$ SILVA, Kalina Vanderlei . Nas Solidões Vastas e Assustadoras... Op. cit, p.136.

${ }^{124}$ PUNTONI, Pedro. A guerra dos bárbaros: povos indígenas e a colonização do sertão nordeste do Brasil, 16501720. São Paulo: Editora Hucitec, 2002, p. 25.

125 ANTONIL. Cultura e opulência do Brasil. Lisboa, 1711, p. 184.

${ }^{126}$ AHU - Avulsos da Paraíba , D. 329 . Paraíba, 27 de maio de 1712.Carta do Capitão- mor da Paraíba, João da Maia da Gama, ao rei, D. João V, sobre os prejuízos com a seca de 1710 a 1712.
} 
de chuvas destes anos parece não ter tardado a chegar ao fim, se restringido à Paraíba, uma vez que não foram encontradas menções para além da supracitada em Pernambuco, ou em outras anexas.

Alguns anos mais tarde, a falta de chuvas voltou a assolar a região, e "no curso dos sucessivos anos de 1722 e 1723 padeceram todas as províncias do Brasil de uma geral e rigorosa secca". De forma diversa da sua precedente, a estiagem atingiu quase toda a extensão das capitanias do Norte, onde, segundo Rocha Pita

abrasava o sol com excessivo ardor a toda nossa América, secando as águas, estragando os frutos, esterilizando as lavouras e matando os gados, de forma que além da falta de todos os víveres era maior a da farinha de mandioca, que é o pão comum dos moradores desse Estado ${ }^{127}$

Nesse mesmo período, João de Abreu Castel Branco, então Capitão-mor da Paraíba, relatou a difícil situação da capitania com a seca, carestia e falta de víveres, "de sorte que a maior parte dos moradores se tem sustentado de raízes do mato impróprio para o alimento e por esta causa tem perecido grande número de pessoas, e particularmente escravos" ${ }^{128}$. A morte por ingestão de alimentos inadequados para o consumo, como carnes em estado de putrefação e raízes venenosas não são incomuns em relatos de período de secas, uma vez que a escassez de alimentos, e os preços exorbitantes dos poucos que restavam, cobravam reações insanas na garantia de sobrevivência. Diante da exacerbada morte de escravos, "desamparando os seus donos na impossibilidade de os sustentar", senhores de engenhos e lavradores solicitavam ao Rei a introdução de algumas embarcações de cativos na capitania, para que pudessem “restabelecer os engenhos e partidos". E solicitavam que o pagamento pelos cativos fosse realizado ao fim de quadro ou cinco anos, tempo julgado necessário para que os plantios se recuperassem da seca ${ }^{129}$.

Com a continuidade da seca, a tensão provocada pela escassez também se refletiu no crescimento da criminalidade. A este respeito, Castel Branco alertava sobre "o estrago que faziam os continuados furtos que encaminhava a uma desordem e perdição geral", onde "nas capitanias vizinhas de Goiana e Pernambuco se faziam já repetidas mortes por este respeito e

\footnotetext{
${ }^{127}$ PITA, Sebastião da Rocha. História da América Portugueza. Bahia: Imprensa Econômica, 1878, p. 436.

${ }^{128}$ AHU - Avulsos da Paraíba, D. 416. Paraíba, 24 de junho de 1724. Carta do Capitão-mor da Paraíba, João de Abreu Castel Branco, ao rei , D. João V, sobre a difícil situação da capitania, em consequência da seca e o lançamento de um bando para punir vadios e ladrões.

129 AHU - Avulsos da Paraíba, D. 452. Paraíba, 21 de julho de 1725. Carta do Capitão-mor da Paraíba, João de Abreu Castel Brando, ao rei, D. João V, sobre as dificuldades com a calamidade da seca e morte de mais da metade dos escravos.
} 
nesta começavam já a roubar com armas" ${ }^{130}$. Os principais alvos dos roubos eram os currais e as plantações de mandioca, que muitas vezes eram arrancadas precocemente pelos ladrões, destruindo as covas que haviam sobrevivido ao mau tempo. Visando reduzir os furtos, e ponderando que destes roubos podia resultar o "extermínio da semente da mandioca que é o pão da terra", o capitão-mor solicitava, então, enrijecer as penas contra esse delito para além do que "permite a jurisdição", determinando "poder executar até a pena de arcabuzar na forma do castigo militar". Além dessa medida, mudas de mandioca foram providenciadas a fim de que com a melhora do tempo se pudesse plantar um roçado perto da cidade, para que dentro de seis meses o gênero pudesse "abundar para todos"131.

Pouco tempo depois da seca ter tido fim, uma nova calamidade veio a afligir a região.

Dessa vez não era a falta de chuvas, mas o excesso delas que causava estragos nas plantações. Como já vimos na discussão sobre a climatologia da região, da mesma forma que podiam ocorrer longos períodos de escassez de chuvas, também poderia acontecer de chover o esperado para meses em apenas um dia, ou semanas. A este respeito, Inácio Accioli de Cerqueira e Silva registrou em suas Memórias históricas e políticas da província da Bahia,

a irregularidade da estação do ano de 1728, e alguns anteriores, durante os quais a seca foi bastante prejudicial, sucedeu o extraordinário inverno, que ocasionou consideráveis danos à cultura do açúcar, sendo tal a inundação que chegou a demolir alguns engenhos, com perda de escravos e gados ${ }^{132}$.

O excesso de chuvas desse ano e as suas consequentes inundações, não ficaram restritas à Bahia, atingindo também Pernambuco e anexas em um cenário de grande devastação. Em requerimento de setembro de 1731, Manuel da Silva Lima, morador da vila de São José do Ribamar, no Ceará, informava da "tão grande e extraordinária" inundação, que não havia se limitado apenas aos vales, áreas mais baixas da região, mas que tinha "chegando a cobrir partes mais altas, levando muitas casas e a maior parte dos mantimentos que estavam nos campos", além de afogar bois e cavalos que andavam pela Ribeira do Jaguaribe ${ }^{133}$.

\footnotetext{
${ }^{130}$ AHU - Avulsos da Paraíba, D. 416. Paraíba, 24 de junho de 1724. Carta do Capitão-mor da Paraíba, João de Abreu Castel Branco, ao rei , D. João V, sobre a difícil situação da capitania, em consequência da seca e o lançamento de um bando para punir vadios e ladrões.

${ }^{131}$ AHU - Avulsos da Paraíba, D. 416. Paraíba, 24 de junho de 1724. Carta do Capitão-mor da Paraíba, João de Abreu Castel Branco, ao rei , D. João V, sobre a difícil situação da capitania, em consequência da seca e o lançamento de um bando para punir vadios e ladrões.

${ }^{132}$ SILVA. Ignacio Accioli de Cerqueira. Memórias históricas e políticas da província da Bahia. Salvador: Typ. Do Correio Mercantil, 1835, p. 163.

${ }^{133}$ AHU- Avulsos do Ceará, D. 124. Ceará, 06 de setembro de 1731. Requerimento de Manuel da Silva Lima e Jerônimo da Fonseca, moradores na vila de São José do Ribamar, ao rei, D. João V, a pedir sejam perdoados parte dos dízimos que arremataram por causa de uma violenta cheia que matou o gado.
} 
Na Paraíba o cenário não parece ter sido muito distinto, onde, em 1729, Francisco Pedro de Mendonça Gorjão, então capitão-mor, solicitou em nome de senhores de engenhos e lavradores, que esses não fossem executados em suas fábricas pelas dívidas que possuíam devido ao difícil estado em que se encontravam. A justificativa dos solicitantes era a forte cheia, alegando que:

Sucedendo haver repetidas chuvas nos sertões mais distantes e veio uma cheia tão repentina e extraordinária que inundou as vargens desta capitania, destruiu engenhos, matou gados e bestas e levou a maior parte das caixas dos moradores dela. Homens e mulheres se viram por muitos dias subidos em árvores para poderem escapar da morte esperando que o Rio lhes desse lugar a poderem baixar delas, e não foi poderosa a caridade e diligência dos homens para que deixassem de morrer várias pessoas afogadas. Havendo engenhos que ficaram totalmente arruinados, [...] ficando nenhum gênero de lavouras de roças e legumes de que estes homens se pudessem e assevero a Vossa Majestade que se faz esta perda digna da maior compunção, além da pobreza em que continuadas secas tem posto estes moradores ${ }^{134}$.

A década de 1730 parece ter seguido o mesmo caminho da anterior, com o registro de um ano seco em $1736^{135}$ e de chuvas excessivas após o evento. Nesse sentindo, Pedro de Monteiro de Macedo informava a Coroa a respeito do "grande castigo" de que padecia esta capitania "com a seca de sete anos e com a inundação de dois anos, tudo sucessivo". A alternância dessas adversidades climáticas teria causado inúmeros prejuízos, fazendo "perecer de fome quase todos os negros", e com a carestia dos gêneros de subsistência, "exaurir de cabedais os mais ricos para o alimento de suas famílias" ${ }^{136}$.

Os discursos acima foram produzidos com o nítido objetivo de delimitar um quadro de miséria e desespero, visando principalmente o abrandamento de dívidas com o Estado português. Possíveis exageros à parte, essas narrativas, tanto sobre as crises motivadas por secas, como por cheias, pontuam cenários de escassez de víveres e destruição de plantações, mostrando o forte impacto da periódica instabilidade climática sobre toda a região.

As três décadas seguintes foram de certa tranquilidade no que diz respeito a crises climáticas, com o registro de duas secas pontuais, em 1743 e 1754. Segundo Studart, o Ceará teria sofrido com uma seca “desde meio do ano de 43 ”, ocasionando a morte de algumas cabeças

\footnotetext{
${ }^{134}$ AHU - Avulsos da Paraíba, D. 606. Paraíba, 19 de outubro de 1729. Consulta do Conselho Ultramarino, ao rei D. João V, sobre a carta do capitão-mor da Paraíba, Francisco Pedro de Mendonça Gorjão, informando da cheia que houve na Capitania, destruindo engenhos e lavradores, em que solicitam para não serem executadas em suas fábricas as dívidas que possuem.

135 AHU - Avulsos da Paraíba, D. 796. Paraíba, 13 de abril de 1736. Carta do capitão-mor da Paraíba, Pedro Monteiro de Macedo, ao rei D. João V, sobre o empréstimo que recebeu da Coroa de quatrocentos e oitenta mil réis, para a capitania e a dificuldade em honrar o compromisso, devido à falta de moedas de ouro, por não ser essa cidade terra de negócio, e em razão da grande seca, não virem mineiros comprar cavalos.

${ }^{136}$ AHU - Avulsos da Paraíba, D. 830. Paraíba, 14 de janeiro de 1738. Carta do capitão-mor da paraiba, Pedro monteiro de Macedo, ao rei, D. João V, sobre as dificuldades com uma seca, uma inundação e a falta de pagamento.
} 
de gado que seus moradores criavam no sertão. A respeito desse ano de chuvas escassas, a Câmara da Vila do Aracati informava que escravos se aproveitaram do momento para fugir de seus senhores, "refugiando-se a quaisquer Aldeias e Missões" ${ }^{137}$. As fugas possivelmente teriam sido ocasionadas pela fome causada pela falta de víveres de primeira necessidade, inerente a períodos secos na região, uma vez que é de se esperar que em momentos como esse os senhores optassem por direcionar os gêneros para seus familiares, além de comprar menos víveres devido à carestia, limitando ainda mais a alimentação da escravaria. Para além desse registro, em 1754 o Governador de Pernambuco se queixava de uma seca que havia se abatido naquela capitania, interferindo na produtividade das minas dos Cariris Novos ${ }^{138}$.

Depois de pouco mais de vinte anos sem a ocorrência de estiagens, em 1775, José César de Meneses, governador de Pernambuco, relatava que na capitania já "se começa a experimentar seca, e com maior excesso no sertão", onde já teria causado a morte de várias reses. A estiagem teria se estendido também para a ilha de Fernando de Noronha, onde, segundo César de Meneses, já faltavam as chuvas há quase um ano, ocasionando "grande mortandade de gados, e algumas doenças" ${ }^{139}$. A ausência de frutas frescas e de uma alimentação rica em nutrientes provocou uma verdadeira epidemia de Mal de Luanda, escorbuto, na ilha, "de que já tinham falecido doze, inclusos neste número quatro soldados" ${ }^{140}$. A falta de chuvas em Fernando de Noronha foi particularmente difícil, uma vez que o seu isolamento e a ausência de fontes de água doce a colocava em uma posição ainda mais delicada e vulnerável. Sobre isto, o comandante de sumaca recém-saída da ilha informava

que naquela ilha tem havido rigorosa seca, que tem morrido muito gado; que as cacimbas se acham secas; e que se o senhor os não socorrer com alguma chuva morrerão todos [...] e que fica socorrido de mantimento até quinze de setembro do corrente ano ${ }^{141}$.

\footnotetext{
${ }^{137}$ AHU - Avulsos do Ceará, D 325. Aracati, 18 de dezembro de 1748. Carta da câmara da vila do Aracati ao rei D. João V, sobre a seca que desde o ano de 1743 tem assolado a Capitania do Ceará e a falta de escravos, que se refugiam nas missões.

${ }^{138}$ AHU- Avulsos de Pernambuco, D. 6306. Recife, 14 de janeiro de 1754. Ofício do Governador da capitania de Pernambuco, Luis José Correia de Sá, ao secretário de estado da Marinha e Ultramar, Diogo de Mendonça Corte Real, sobre a seca que se abateu naquela capitania

139 AHU - Avulsos de Pernambuco, D. 9081. Recife, 4 de abril de 1775. Ofício do governador da capitania de Pernambuco, José César de Meneses, ao secretário de estado da Marinha e Ultramar, Martinho de Melo e Castro, sobre a seca que assola a dita capitania, principalmente o sertão, chegando até a ilha de Fernando de Noronha.

${ }^{140}$ AHU - Avulsos de Pernambuco, D. 9308. Recife , 6 de março de 1776. Ofício do governador da capitania de Pernambuco, José César de Menezes, ao Secretário de estado da Marinha e Ultramar, Martinho de Melo e Castro, sobre o destacamento enviado para a ilha de Fernando de Noronha e os desertores e soldados presos por desordens e crimes também enviados à mesma; informando também da seca que continua assolar a região e do falecimento de várias pessoas com o mal de Luanda e bexigas.

${ }^{141}$ AHU- Avulsos de Pernambuco, D. 10163. Recife, 7 de maio de 1780.Oficio do governador da capitania de Pernambuco, José César de Meneses, aos secretário de estado da Marinha e Ultramar, Martinho de Melo e Castro, sobre o envio de presos e mantimentos para o presídio de Fernando de Noronha, e informando acerca da rigorosa
} 
Para além do sertão e da Ilha de Fernando de Noronha, a falta de chuvas também alcançou a zona da mata e os canaviais, onde, Segundo Felipe Melo, o fenômeno teria de fato motivado uma baixa na produção açucareira em $1777^{142}$. Neste mesmo ano, a Mesa da Inspeção de Pernambuco, informava a respeito da diminuta "colheita de açúcares", que não chegava à metade dos anos comuns, motivada pela "grande falta de águas do ano próximo passado, nos meses competentes". Tal informação nos leva a crer que a estiagem teria ocorrido justamente na quadra chuvosa da região, entre os meses de fevereiro e maio, período considerado de extrema importância para o cultivo de qualquer gênero, uma vez que a ocorrência de chuvas é ainda mais incerta nos demais meses. Diante da pequena colheita, e visando compensar os prejuízos, a Mesa de Inspeção solicitava, então, que cada arroba de açúcar fosse acrescida em duzentos réis. O pedido, entretanto, foi imediatamente barrado pela Diretoria da Companhia Geral de Comércio de Pernambuco e Paraíba ${ }^{143}$. A situação nos canaviais só teve melhora no ano posterior, quando, segundo o governador, graças ao tempo favorável os engenhos estavam moendo, e prometia "este ano haver uma boa safra" ${ }^{144}$.

Anos depois, como já era costumeiro, não foi a seca, mas o excesso de chuvas que causou prejuízos aos agricultores e moradores da região. A respeito desse episódio, Dom Tomás José de Melo relatou que os donos de partidos e senhores de engenho da Paraíba se encontravam "reduzidos à última miséria pela violenta e inesperada cheia" que se deu entre os anos de 1789 e 1790. A calamidade teria feito a produção do açúcar cair de 527 caixas para apenas 89, no ano posterior à inundação, com uma rápida recuperação já na safra de 1791, que teria rendido 502 caixas $^{145}$. Nesse mesmo momento, o excesso de chuvas, e a consequente cheia, teriam desencadeado problemas relacionados à saúde da população no Ceará.

\footnotetext{
seca e elevada mortandade de gado naquela ilhas, e que há madeira no porto de Jaraguá pronta para ser embarcada para o Reino.

${ }^{142}$ MELO, Felipe Souza. O negócio de Pernambuco: financiamento, comércio e transporte na segunda metade do século XVIII. Dissertação de mestrado. São Paulo: USP/FFLCH/PPGHE, 2017, p. 31 - 32.

${ }^{143}$ AHU- Avulsos de Pernambuco, D. 9574. Recife, 6 de março de 1777. Oficio da Mesa da Inspeção da capitania de Pernambuco ao secretário de estado da Marinha e Ultramar, Martinho de Melo e Castro, sobre se acrescentar 200 réis em cada arroba de açúcar, para acrescentar o referido gênero, por causa da diminuta colheita do dito ano. ${ }^{144}$ AHU - Avulsos de Pernambuco, D. 9889. Recife, 17 de outubro de 1778. Ofício do governador da capitania de Pernambuco, José César de Meneses, ao secretário de estado da Marinha e Ultramar, Martinho de melo e Castro, sobre uma boa safra de açúcar no ano de 1778, devido ao tempo favorável, mas que a seca assola o sertão provocando a morte do gado.

${ }^{145}$ AHU- Avulsos de Pernambuco, D. 12437. Recife, 16 de agosto de 1791, agosto, 16, Recife. Carta do governado da capitania de Pernambuco, D. Tomás José de Melo à Rainha D. Maria, Informando a representação dos oficiais da Câmara da Paraíba sobre os prejuízos causados pelas enchentes e os benefícios que pedem o senhores dos engenhos, donos de partidos e lavradores de cana.
} 
Segundo Ana Carolina Viotti, em finais dos setecentos já se tinha conhecimento da estreita ligação entre o clima e as doenças, e o ambiente já era relacionado como "causador do mal”, responsável por diversas moléstias, como febres intermitentes e remitentes, e disenterias ${ }^{146}$. Em 1791, João Lopes Cardozo Machado, comissário e Juiz delegado de medicina foi enviado para socorrer o sertão cearense, onde "em todos os invernos padeceram sempre febres intermitentes", que atacavam principalmente os "desacautelados e indigentes". Entretanto, depois das "grandes águas de 1789”, estas febres se tornaram mais comuns, tendo sua principal causa nos "muitos corpos de animais mortos arrastados por aquelas cheias"147. A situação teria se agravado pela fome e pela procura por "alimentos nocivos", uma vez que segundo Machado além do tratamento com remédios, a dieta com bons alimentos era "uma das condições necessárias para a felicidade na cura”, e a pobreza e a falta de carne fresca tornavam a enfermidade incurável. Nesse momento, o número de mortos já havia chegado a quatrocentos e oitenta, apenas na Freguesia de Sobral ${ }^{148}$.

Não foram encontradas mais informações sobre a epidemia para além das supracitadas, desta forma não sabemos como teria ocorrido a sua possível recuperação. Entretanto, não tardou para que essa população voltasse a sofrer com as consequências da falta de estabilidade do clima da região, e apenas dois anos depois das cheias, em 1791 uma seca generalizada alcançou toda a faixa territorial que ia de Pernambuco ao Ceará.

As intempéries climáticas foram uma constante na história das capitanias de Pernambuco e suas anexas, onde períodos de tempos favoráveis alternaram-se incessantemente com anos de secas e episódio de chuvas excessivas ao longo de séculos. De maneira que esses fenômenos, definitivamente, atuaram como elementos perturbadores e desorganizadores da estrutura produtiva, trazendo inúmeros prejuízos. Onde cada crise climática teve suas especificidades, aliada a fatores que poderiam contribuir para aprofundá-las ou amenizá-las. Segundo Mike Davis, historicamente, as sociedades agrícolas situadas em regiões onde a variabilidade de chuva era alta, em geral, se encontravam adaptadas para lidar com severas

\footnotetext{
146 VIOTTI, Ana Carolina. As práticas e os saberes médicos no Brasil Colonial (1677-1808). Dissertação de Mestrado. Franca: Unesp/ FCS/ PPGH, 2012, p. 54-55.

147 AHU - Avulsos de Pernambuco, D. 12587. Recife, 25 de maio de 1792. Ofício do governador da capitania de Pernambuco D. Tomás José de Melo, ao secretário de estado da Marinha e Ultramar, Martinho de Melo e Castro, remetendo os documentos referentes a epidemia na capitania do Ceará.

148 Biblioteca Nacional - Manuscritos, cmc_ms618_10_23. Correspondências oficias do governador de Pernambuco e de membros do governo interino referentes à administração da mesma capitania. Recife, Pernambuco, 1790-1799.
} 
insuficiências de chuvas em um único ano. Entretanto, a situação mudava completamente diante da falta de chuvas em pelo menos dois anos sucessivos ${ }^{149}$.

A seca que ocorreu entre os anos de 1791 e 1793, objeto principal do presente trabalho, persistiu por tempo suficiente para desorganizar as forças produtivas da Capitania Geral de Pernambuco, com consequências na agricultura e na pecuária, amplamente sentidas pela população. Referida como a "seca grande" colonial ${ }^{150}$, o período foi retratado como um cenário de grande devastação, escassez e fome. A potencialidade perturbadora da seca, para além da intensidade do fenômeno em si, esteve intimamente relacionada à ocupação de regiões climaticamente instáveis, ao maior incentivo à diversificação da agricultura de exportação, e a maior tensão entre a produção para o abastecimento e para a exportação. Todos esses fatores serão mais bem tratados a seguir.

${ }^{149}$ DAVIS, Mike. Holocaustos Coloniais - Clima, Fome e Imperialismo na Formação do Terceiro Mundo. Rio de Janeiro: Record, 2002, p. 28-29.

${ }^{150}$ JOFFILY, Irenêo. Notas sobre a Parahyba. op. cit p. 433. 


\section{Capítulo 2. Produção de alimentos e abastecimento na Capitania de Pernambuco e Anexas em finais do século XVIII}

A preocupação com o abastecimento das primeiras vilas e povoados da América portuguesa já aparece claramente no Regimento de Tomé de Sousa de 1548, ao ordenar que "se faça em um dia de cada semana, ou mais, se vos parecerem necessários, feira, a que os gentios possam vir vender o que tiverem e quiserem, e comprar o que houver mister". A ocupação inicial do território colonial se desenvolveu a partir da exploração baseada na implantação de atividades produtivas de exportação, principalmente da agricultura canavieira. O desenvolvimento das grandes lavouras de cana demandou um grande emprego de mão de obra e de capitais, para isso, africanos escravizados passaram a ser importados em larga escala. $\mathrm{O}$ crescimento populacional decorrente dessa expansão canavieira e da intensificação da escravidão levaram, então, à necessidade de se produzir, em área povoada, alimentos que se adaptassem ao clima e ao solo da colônia.

Diante da necessidade de se abastecer a população em crescimento, foram introduzidos animais e vegetais oriundos de terras por onde se estendia a influência comercial portuguesa. Do continente africano vieram vegetais, como o inhame, o cará e o sorgo; da Europa, desde a primeira metade do século XVI, foram trazidos animais, sobretudo caprinos, bovinos, equinos e suínos; da Ásia, fruteiras como a mangueira, a jaqueira, a bananeira e o arroz ${ }^{151}$. Além do processo de aclimatação de vegetais e animais de outras regiões, os conhecimentos trocados com os indígenas possibilitaram a reprodução de lavouras locais de milho, algodão, mandioca, batata-doce e feijão ${ }^{152}$.

Vários teriam sido os papéis dos cultivos e produções de subsistência na colônia portuguesa que se estabelecia. Entre eles estariam o de ocupar a terra "desbravando-a e povoando-a", e o de se organizar "sob formas de trabalho familiar para produzir excedentes e atender, progressivamente, às necessidades dos núcleos urbanos em expansão, além de suprir as frotas que se dirigiam ao sul e à África" ${ }^{153}$. Nesse momento, buscou-se debruçar sobre dois tipos de produções que, além de significativas no provimento das populações das capitanias de

\footnotetext{
${ }^{151}$ MELLO, José Antônio Goçalves de. Notas acerca da introdução de vegetais exóticos em Pernambuco. Recife: Boletim do Instituto Joaquim Nabuco de Pesquisas Sociais, 1966, p. 117.

152 ANDRADE, Manuel Correia de. A pecuária e a produção de alimentos no período colonial. In: SZMRECSÁNYI, Tamás (Org.). História Econômica do Período Colonial. $2^{\text {a }}$ Ed. revista. São Paulo: HUCITEC/ Associação Brasileira de Pesquisadores em História Econômica/ Editora da Universidade de São Paulo/ Imprensa Oficial, 2002, p. 102.

${ }^{153}$ LINHARES, Maria Yedda. Pecuária, Alimentos e Sistemas Agrários no Brasil séculos XVII e XVIII. Revista Tempo, Niterói, v. 1, n. 2, p. 135.
} 
Pernambuco e Anexas, são indissociáveis do objeto principal do presente trabalho, a seca. A criação de gado, que além do fornecimento da carne, foi uma grande responsável pela ampliação de fronteira e consequentemente pela interiorização de uma parcela da população, ocupando regiões climaticamente mais instáveis. O cultivo da mandioca, e a produção da farinha, que constitui-se como o alimento básico da região aqui estudada, alvo constante da atenção das autoridades coloniais, que buscavam sempre estimular a sua produção, tendo em vista a irregularidade da sua produção, bem como a sua falta por motivos climáticos. Ademais, também buscou-se abordar os principais problemas ligados à produção de alimentos em finais do século XVIII.

\section{A pecuária e o seu papel na produção do território}

As experiências dos lusitanos com o gado já vinham da sua implementação em outros espaços coloniais do Império português, como Cabo Verde, Madeira e as ilhas Canárias, não existindo muita dificuldade na sua aclimatação aos trópicos. Entretanto, o desenvolvimento sistemático desse produto, na ainda pouco explorada América portuguesa do século XVII, efetuou expressivas mudanças. Essas transformações ocorreram tanto em relação a questões territoriais, visando o estabelecimento das criações, bem como no que diz respeito ao aniquilamento de populações indígenas, como consequência do uso dessas terras.

Em inícios do século XVII, os canaviais ocupavam praticamente todo o litoral, e grande parte da zona da mata, expandindo-se pelos rios, até onde o solo bom para o cultivo da cana, o argiloso, consentisse. Enquanto isso, os interflúvios arenosos iam sendo destinados ao cultivo de alimentos e a pecuária extensiva ${ }^{154}$, restando poucos espaços para essas produções, o que contribuía para a escassez de comida e de transporte, uma vez que a força motriz de muitos engenhos das plantações açucareiras e o transporte dos seus produtos eram feitos por meio do uso de bois.

A proximidade entre as áreas da pecuária e da agricultura teriam gerado diversos problemas de convivência, uma vez que o gado criado solto destruía plantações. Diante desse problema, a coroa baixou o alvará de 27 de janeiro de 1701, ampliando um de 1688, determinando que:

tivesse efeito não somente nas dez léguas do Recôncavo, mas em toda a parte onde chegasse a maré, correndo as mesmas dez léguas da margem dos rios pela terra a dentro e que em nenhum dos sítios, nem nas três capitanias do

\footnotetext{
${ }^{154}$ ANDRADE, Manuel Correia de. A pecuária e a produção de alimentos no período colonial. In: SZMRECSÁNYI, Tamás (Org.). História Econômica do Período Colonial. $2^{\mathrm{a}}$ Ed. revista. São Paulo: HUCITEC/ Associação Brasileira de Pesquisadores em História Econômica/ Editora da Universidade de São Paulo/ Imprensa Oficial, 2002, p. 100 - 101.
} 
Camamu, houvesse a inovação do gado de criar e só lhes fosse lícito terem o de serviço, fazendo as pessoas que o tivessem pasto fechado, com cercas tão fortes que ele não pudesse sair a fazer prejuízos às roças e lavouras vizinhas ${ }^{155}$.

O evidente propósito legislador desse decreto é o de disciplinar a produção de gado, atendendo ao abastecimento da população bem como aos interesses da grande lavoura canavieira. Segundo Maria Yedda Linhares,

o decreto deixa transparecer uma política definida: a de delimitar em áreas próprias e resguardar as três paisagens que passarão a configurar a economia rural da Colônia, isto é, a grande lavoura com seus campos definidos, incluía a área industrial; a lavoura de abastecimento, que atendia aos interesses de consumidores urbanos e comerciantes de Salvador [e do Recife], devendo incluir a criação controlada de animais de tiro necessários ao transporte das mercadorias ao porto e, por fim, a pecuária extensiva na fronteira móvel, a cargo de sesmeiros e arrendatários, último elo fundamental de um macromodelo agrário ${ }^{156}$.

Ao determinar que a criação de gados só fosse permitida a, pelo menos, dez léguas do litoral, impelindo a pecuária para o sertão, o supracitado alvará foi o último impulso para o estabelecimento concreto de maiores contingentes populacionais nas regiões interioranas das capitanias do Norte oriental. Como já é sabido, o processo de interiorização do território da América portuguesa aconteceu de forma tardia, uma vez que o princípio da colonização portuguesa limitou-se em povoar a faixa litorânea do território, que atendia bem aos propósitos da principal lavoura de exportação. Os primeiros movimentos de expansão territorial ao interior teriam tido princípio em meados do século XVII ${ }^{157}$. Para Capistrano de Abreu ${ }^{158}$, a interiorização territorial colonial teria se iniciado notadamente nas capitanias da Bahia e Pernambuco, onde a exploração do território para o cultivo da cana já se encontrava bem estabelecido, e a sua colonização, inclusive, já produzia excedentes populacionais.

Além da urgência do alargamento de fronteiras para a produção de alimentos e a criação de gado como solução para as crises frequentes de abastecimento que afetavam as regiões produtoras das capitanias do norte das regiões próximas a cidade de Salvador, o fluxo inicial rumo ao interior também buscava atender a uma necessidade metropolitana, que buscava meios para se livrar da crise econômica por qual passava a principal cultura da colônia. Após a expulsão holandesa, em 1654, a economia açucareira foi duramente atingida por fatores internos e externos que contribuíram para que a produção desandasse. A sua cultura foi prejudicada por

\footnotetext{
155 Anais da Biblioteca Nacional - 31, 90-91.

${ }^{156}$ LINHARES, Maria Yedda Leite. A pecuária e a produção de alimentos na colônia. IN: SZMRECSÀNYI, Tamás (Org.). História Econômica do Período Colonial. $2^{a}$ Ed. Revista - São Paulo: Editora da Universidade de São Paulo / Imprensa Oficial, 2002, p. 113 -114.

${ }^{157}$ SILVA, Kalina Wanderlei. Nas solidões Vastas e Assustadoras...Op. cit, p. 111.

${ }^{158}$ ABREU, Capistrano de. Caminhos Antigos e Povoamento do Brasil. São Paulo: Livraria Briguiet, 1960. p. 34.
} 
fatores climáticos e intempéries, inerentes a qualquer tipo de cultura dos trópicos, bem como pela concorrência com a produção de açúcar antilhano, que ocasionou a baixa de preços da mercadoria juntamente com o aumento dos preços dos escravos, graças a grande demanda e procura desse tipo de mão de obra no continente africano ${ }^{159}$. Procurando reanimar a economia, a Coroa passou, então, a encorajar os colonos a desbravarem o interior ${ }^{160}$. Segundo Kalina Wanderley,

\begin{abstract}
A conquista dos interiores continentais do Estado do Brasil foi um empreendimento que misturou iniciativas particulares, de senhores de engenhos que buscaram expandir seu poderio através da criação de gado nas imensidões para além da área canavieira, com ações estatais. A Coroa foi chamada a intervir, em realidade, quando os particulares se depararam com um obstáculo instransponível para a instalação de suas fazendas de gado: a resistência indígena. Mas as investidas da Coroa dependiam sobremaneira da gente do litoral que compunha suas tropas, da gente livre das vilas açucareiras ${ }^{161}$.
\end{abstract}

Esse movimento de conquista das regiões interioranas, se deslocando pela área geográfica que atualmente se denomina de agreste, até a chegada ao sertão, passou a incomodar populações indígenas que se situavam naquelas regiões de "fronteira". Segundo Puntoni, apesar da utilização de índios frecheiros aliados, o que alimentava o tradicional ódio entre as tribos inimigas, a reação dos tapuias devia-se "muito mais à pressão sufocante do avanço da economia pastoril, que demandava mais terras e mão-de-obra, fatores que implicavam arrocho sobre as populações de fronteira" 162 .

Para que os sertões deixassem de ser territórios de conquista e fossem transformados em espaços coloniais, foi empreendida uma luta brutal entre colonos e nativos. Não se sabe precisar com exatidão o princípio desses conflitos, que ficaram conhecidos como "Guerra dos Bárbaros”, entretanto Maria Idalina Pires aponta que o primeiro registro do conflito data de "logo após a expulsão dos flamengos, quando a penetração promovida pelo colonizador começa a ter maior impulso" ${ }^{163}$. Estes embates ocorreram em todo o sertão norte oriental do Estado do Brasil, entretanto foram mais acentuados nas regiões do rio São Francisco, que corresponde aos sertões das capitanias da Bahia e de Pernambuco, e do rio Piranhas-Açu, parte dos sertões das capitanias da Paraíba e do Rio Grande ${ }^{164}$.

\footnotetext{
${ }^{159}$ PUNTONI, Pedro. A guerra dos Bárbaros...op. cit. p. $24-25$.

${ }^{160}$ SILVA, Kalina Vanderlei. Nas Solidões Vastas e Assustadoras... Op. cit. p.136.

${ }^{161}$ Ibidem, p. 27.

162 PUNTONI, Pedro. A guerra dos Bárbaros... Op. cit. p. 132.

163 PIRES, Maria Idalina da Cruz. Guerra dos Bárbaros: resistência indígena e conflitos no nordeste colonial. Recife: FUNDARPE, 1990, p. 56.

${ }^{164}$ Idem.
} 
A maior parte dos colonizadores dos sertões onde a economia pastoril se desenvolveu teve sua origem na zona açucareira, no litoral leste, a partir do deslocamento populacional propiciado pela formação de tropas para o combate no sertão. As vilas açucareiras se encontravam repletas de pobres e "vadios", nesse sentido a Coroa buscou aproveitar esse recurso humano disponível empregando-o em suas tentativas de expandir as fronteiras sertanejas. Dessa forma, desses centros conquistadores não saíram apenas senhores já enriquecidos que haviam sido agraciados com sesmarias, mas igualmente a população excedente dos canaviais, que servia de mão de obra. Para Kalina Wanderlei Silva,

o deslocamento forçado de pobres e vadios dos núcleos urbanos açucareiros para o sertão respondia assim a uma política de desafogar os saturados núcleos originais, sem prejudicar o empreendimento agroexportador. A escravidão só convivia até certo ponto com a mãode-obra livre urbana, e aqueles que não conseguiam se inserir no mercado de trabalho terminavam por ser um risco ou, na melhor das hipóteses, um empecilho à colonização açucareira. A melhor saída para isso era recrutar o excedente populacional, basicamente os vadios e pobres livres menos estabelecidos, inseri-los em uma forma de degredo útil e mandá-los combater os índios do sertão ${ }^{165}$.

Apesar do violento conflito, os colonos continuaram seus avanços pelos sertões, a procura de terras e água para o cultivo de lavouras e a criação do gado. Dessa forma, partindo dos centros já colonizados e estabelecido de Olinda e de Salvador, os currais foram adentrando o espaço sertanejo, seguindo os cursos dos rios, que viabilizavam a sustentação das rezes. A este respeito, Pedro Puntoni confirma essa característica da atividade pastoril desenvolvida nas capitanias do norte, apontando que:

As fazendas de gado, grosso modo, acompanhavam as margens dos rios, uma vez que na região semi-árida o fornecimento de água era fator essencial para garantir a ocupação e a criação do gado. Os rios São Francisco ao sul, e o Parnaíba, ao norte eram os principais eixos da ocupação, por serem rios perenes; os demais na maioria seus afluentes, ainda abrigavam algumas das fazendas ${ }^{166}$.

Segundo Manuel Correia de Andrade, a expansão da criação de gado para as regiões interioranas teria sido favorecida por algumas condições econômicas e naturais ${ }^{167}$. Do ponto de vista econômico, os criadores de gado, além de contarem com um mercado certo no abastecimento de carne, couro e de animais para trabalho, após um verdadeiro genocídio

\footnotetext{
165 SILVA, Kalina Vanderlei. Nas Solidões Vastas e Assustadoras... op. cit, p.133.

166 PUNTONI, Pedro. A guerra dos Bárbaros... Op. cit. p. 26.

${ }^{167}$ ANDRADE, Manuel Correia de. A pecuária e a produção de alimentos no período colonial. In: SZMRECSÁNYI, Tamás (Org.). História Econômica do Período Colonial. $2^{a}$ Ed. revista. São Paulo: HUCITEC/ Associação Brasileira de Pesquisadores em História Econômica/ Editora da Universidade de São Paulo/ Imprensa Oficial, 2002, p. 102.
} 
indígena, podiam contar com a reserva de mão de obra oriunda dos nativos que agora se encontravam sedentarizados em aldeamentos. Os indígenas sedentarizados tornavam-se produtores de alimentos e também podiam ser recrutados em momentos de maior necessidade de braços para os trabalhos agrícolas, ou para combater outras tribos ${ }^{168}$. Do ponto de vista natural, o clima semiárido impedia a proliferação de verminoses, e no período de chuvas oferecia uma boa pastagem natural, além disso, no período seco existiam "ilhas" úmidas nas margens dos rios e nas serras para onde o gado poderia ser levado ${ }^{169}$.

No processo de colonização de novas regiões, os colonos europeus levavam consigo uma "biota portátil", com o intuito de acrescentar à flora e à fauna local plantas e animais domesticados oriundos do velho mundo, cujo manejo e produtos derivados já eram por eles $\operatorname{conhecidos}^{170}$. Entre esses elementos, o gado bovino apresentava a grande vantagem de poder consumir alimentos vegetais que o homem não poderia utilizar diretamente, e transformar essa celulose em carne, leite, fibra e couro, além de servir como tração animal ${ }^{171}$. Essas características, associadas ao seu eficiente sistema termorregulador, que tolera melhor o calor e a luz direta do sol, e à sua autossuficiência natural facilitaram a adaptação do gado ao semiárido sertanejo. Somadas, essas particularidades proporcionaram a propagação dos rebanhos nos sertões da Capitania Geral de Pernambuco ${ }^{172}$.

Ao adentrar no território seguindo as margens dos rios, o homem, o boi, o machado e o fogo paulatinamente modificavam a paisagem sertaneja, com esforço mínimo e arrancando o máximo proveito da natureza. Em inícios do século XIX, o avanço da criação sobre os ecossistemas primários chamou a atenção de Antônio Paulet. Ao escrever a respeito do Ceará, o coronel questionava "a nova face, que a população e a cultura têm dado ao terreno", graças ao "mal entendido sistema de derrubar todas as matas"173. A continuidade deste hábito, opinava Paulet, teria "dissipado muitos princípios de umidade e acarretado uma quase não interrompida serie de anos secos"174.

\footnotetext{
${ }_{168}$ ANDRADE, Manuel Correia de. A pecuária e a produção de alimentos no período colonial... op. cit, p. 102 169 Idem.

${ }^{170}$ CROSBY, Alfred W. Imperialismo Ecológico. A expansão biológica da Europa: 900 - 1900. São Paulo: Companhia das Letras, 1991, p. 238.

${ }^{171}$ FONTANA, Josep. Introdução ao estudo da história geral. São Paulo: EDUSC, 2000, p. 110.

${ }^{172}$ CROSBY, Alfred W. Imperialismo Ecológico... Op. cit. p. 159-160.

${ }^{173}$ PAULET, Antônio José da Silva. Descripção Geográfica Abreviada da Capitania do Ceará. RIHGB, v.96, pt. 2, 1897. Rio de Janeiro: IHGB, 1897, p. 9.

${ }^{174}$ Idem.
} 
No preparo do terreno para a criação, primeiramente, retirava-se a vegetação impalatável e sem valor para o gado, poupando apenas arbustos e árvores de ramas, e semeando capins e leguminosas ${ }^{175}$. A retirada das plantas, forragens e espinhos indesejados era feita com fogo, e repetida sempre que o capim ficava muito alto ou quando os carrapatos se tornavam muito numerosos. Ao reduzir as plantas impalatáveis a cinzas, a queimada enriquecia o solo, se a chuva logo viesse. Apesar desse benefício, o fogo deixava o solo mais exposto, provocando maior erosão, e reduzindo também a sua permeabilidade ${ }^{176}$. Diante da ação do fogo, o solo perdia também "nitrogênio e as bactérias que participam de sua fixação ao solo, essencial à nutrição animal"177. À essa tendência de longo prazo de pastos e animais degenerarem, os criadores reagiam expandindo-se cada vez mais para novos pastos.

No mapa a seguir (mapa 1), é possível observar a rota de penetração da pecuária no sertão das capitanias do norte oriental. As setas contínuas representam os caminhos oriundos da cidade de Salvador, já as setas pontilhadas demonstram os caminhos que saíram de Olinda. Assim, a expansão pecuária originada em Pernambuco foi paulatinamente ocupando com currais as ribeiras dos rios Paraíba, Piancó, Patú, Seridó, Piranhas e Rio do Peixe, na capitania da Paraíba; Mipibú, Potengi, Piranhas-Assú, Seridó e Apodi, na capitania do Rio Grande do Norte; Ceará, Jaguaribe e Acaraú, na capitania do Ceará. Após a ocupação colonial das terras mais próximas das margens dos rios ou de "olhos d'água", áreas menos dotadas de recursos hídricos, ainda que em menor intensidade, também foram sendo povoadas.

175 DUQUE, José Guimarães. O Nordeste e as lavouras xerófilas. Fortaleza: Banco do Nordeste do Brasil , 2004, p. 107.

${ }^{176}$ DEAN, Warren. A ferro e fogo. A história e a devastação da Mata Atlântica brasileira. São Paulo: Companhia das Letras, 2018, p. 128 - 129.

${ }^{177}$ Ibidem, p. 131. 


\section{Mapa 1: Rotas de Penetração da Pecuária}

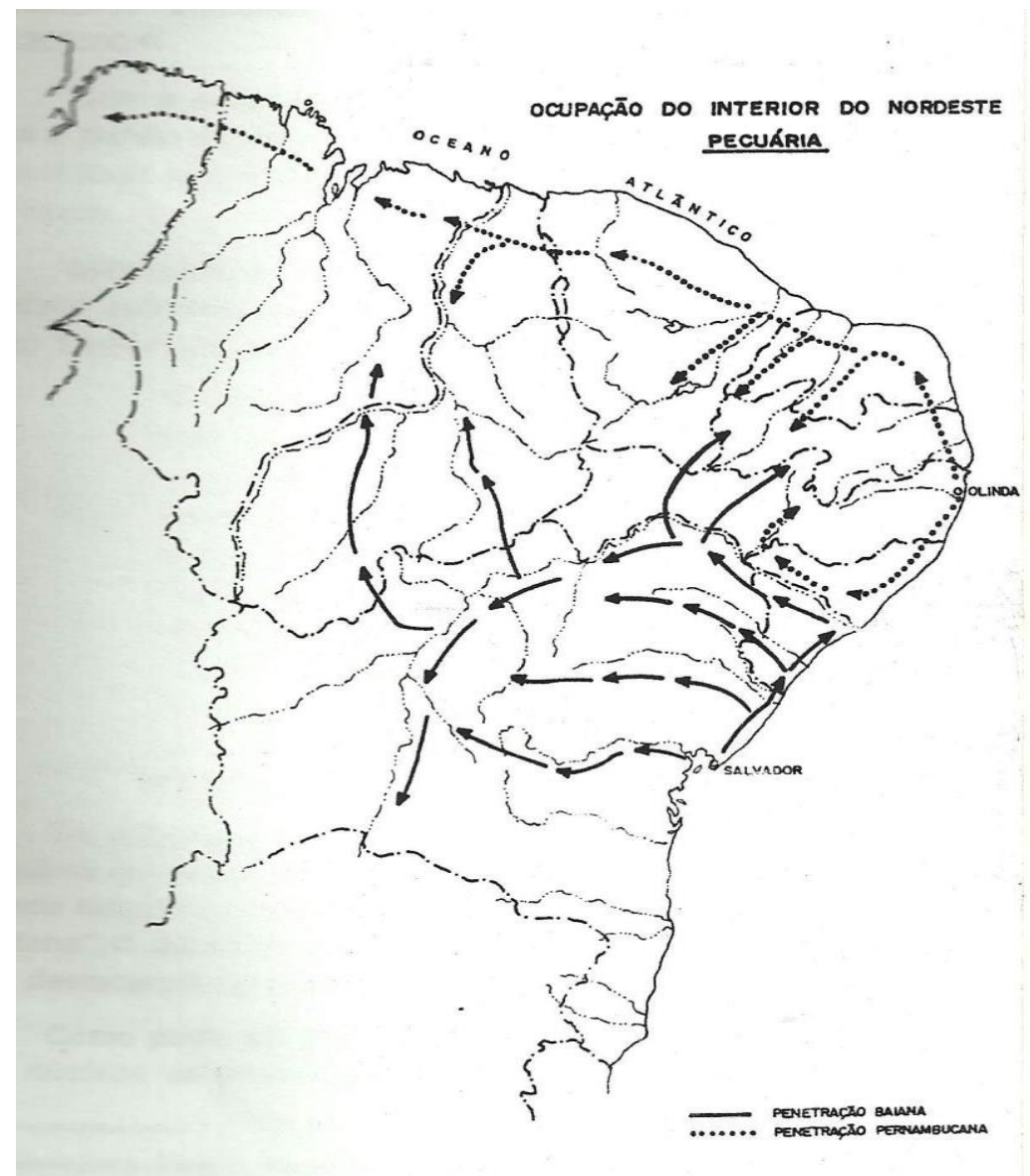

Fonte: ANDRADE, Manuel Correia de. O processo de ocupação do Espaço Regional do Nordeste. Recife: Gráfica Editora, 1975, p. 23.

A ocupação concreta das terras interioranas foi ocorrendo por meio da concessão de sesmarias, que inicialmente foram doadas a homens que ocuparam um papel de destaque nas batalhas travadas contra os holandeses ${ }^{178}$. Após isso, foram sendo concedidas àqueles que com seus próprios capitais empreenderam expedições de enfrentamento aos nativos buscando a ocupação da terra. Assim, após uma série de expedições iniciais de abertura de caminho, as autoridades coloniais relegaram essa área, uma vez que a mesma não se encontrava plenamente inserida nos projetos de produção para exportação, e o empreendimento pecuarista assumiu basicamente um caráter privado.

Esse sistema de acesso a terras na forma de sesmarias esteve na base da estrutura fundiária da América portuguesa. Criada em 1375 por Dom Fernando I, a lei de sesmaria fez parte de um conjunto de medidas adotadas pelo rei com o objetivo de combater a baixa produção dos campos do reino, e a consequente crise aguda de abastecimento desencadeada pela

${ }^{178}$ SILVA, Kalina Wanderley. Nas solidões vastas...Op. cit. p. 37. 
mesma $^{179}$. Por meio dela buscou-se, então, condicionar o direito da terra ao seu efetivo cultivo. No território colonial, a lei de sesmarias foi usada como forma de despertar o interesse em conquistar e povoar regiões que se encontravam desocupadas, possibilitando a ocupação de terras para a produção do açúcar no litoral, bem como a criação de gados e a produção de seus derivados no sertão. O uso produtivo da terra constituía, em tese, na grande obrigação daqueles que eram contemplados com sesmarias, uma vez que "pela lei sesmarial, o colono que recebia uma data adquiria o domínio pleno da terra, desde que preenchesse todos os requisitos formais" 180

Em finais de seiscentos e ao longo do século XVIII, muitos foram os pedidos de sesmarias para as regiões interioranas de Pernambuco e anexas. Os suplicantes de datas de sesmarias utilizavam diversas justificativas no intuito de conseguir a concessão, como alegar participação na guerra contra os indígenas, risco de vida em alguma ação feita em benefício da Coroa, o descobrimento de terras não povoadas e não cultivadas, ter gado (mas não possuir terra para a criação). Essas solicitações podiam ser feitas de duas formas, a individual, quando um morador solicitava a terra de forma isolada, e em condomínio, que caracterizava-se pelo pedido coletivo da sesmaria, em sociedade ${ }^{181}$.

Nesse sentido, têm-se alguns exemplos diversos na documentação referente às datas de sesmarias da capitania Geral de Pernambuco. Em 1700, era registrado um pedido coletivo feito por parte do Sargento-mor Gonçalo de Oliveira ledo, Matheus Pereira de Oliveira, Capitão Francisco Pereira de Oliveira, Capitão Bento Correia de Lima Sargento-mor João de Andrade, Licenciado Luis de Mendonça de Sá, João de Souto Maior, Bernardinho de Mendonça Bezerra, Tenente Francisco Fernandes, Capitão José Fernandes, todos moradores da capitania da Paraíba, que fizeram requerimentos de terras na ribeira do rio Piranhas. Os suplicantes justificaram que "tinham gados no sertão para povoar terras, das quaes estavam faltas, e alguns haviam feito serviços a Sua Magestade na defença do Tapuia”. Além disso, reivindicaram a terra se apoiando num discurso de legalidade, afirmando no pedido que as terras se encontravam devolutas, que nunca foram dadas, sem uso, acrescentando que "se o foram(dadas) não povoaram, e conforme ordem do dito Senhor se podam tornar a dar à pessoa que as povoasse

\footnotetext{
179 ALVEAL, Carmen Margarida Oliveira. História e Direito: sesmarias e conflitos de terras entre índios em freguesias extramuros no Rio de Janeiro (século XVIII). 2002. 150 p. Dissertação (Mestrado em História). Universidade Federal do Rio de Janeiro, p. 60-61.

${ }^{180}$ BRANDÃO, Tanya Maria Pires. A elite colonial piauiense: família e poder. Recife: Ed. Universitária da UFPE, 2012 , p. 293.

${ }^{181}$ Ibidem, p. 293.
} 
para aumento dos dízimos Reais"182. A data de sesmaria foi concedida, com "a condição de que em cada légoa porem um curral de gado dentro de um ano que se lhes passe a carta" ${ }^{183}$.

No requerimento acima citado é possível identificar como justificativas dadas pelos suplicantes para a concessão de terras o fato de possuírem gados, mas não terras para a sua criação, bem como a participação nas guerras contra os indígenas. Visando o estabelecimento de currais, foram solicitadas quatro léguas em quadra para cada requerente. Sobre isso, é interessante pontuar a falta de noção da proporção de terras a povoar por parte dos suplicantes, chegando ao ponto de solicitarem um pedido coletivo que ocuparia boa parte da ribeira de um importante rio da Paraíba, o que pode ser um indicio de que a região se encontrava pouco colonizada e a doação dessas terras havia se iniciado recentemente. Ao mesmo tempo, a solicitação poderia ser uma estratégia dos suplicantes para controlar grandes extensões de terra e a população dispersa que lá havia.

Em outras situações, as solicitações de sesmarias são feitas posteriormente à ocupação da terra pelo requerente. Em 1667, o sargento-mor Pedro Borges Pacheco e o capitão Francisco de Abreu de Lima, solicitavam confirmação de cinquenta léguas em quadra na Ribeira do Ceará- Mirim, pois os suplicantes com "grande risco de suas vidas, e dispêndio de suas fazendas por causa do gentio" haviam ocupado as terras, acrescentando que "porque eles suplicantes já cultivam as ditas terras, e para a poderem fazer com maior dispêndio de suas fazendas, lhes devia fazer Vossa Alteza confirmar de que resultaria grande crescimento nos dízimos"184

A partir da documentação trabalhada e da historiografia já estabelecida sobre o assunto, é possível observar que boa parte das sesmarias solicitadas nas regiões interioranas das capitanias de Pernambuco e anexas se encontrava ligada à criação de gado e ao estabelecimento de currais. Na tabela abaixo, que traz informações sobre o número de sesmarias concedidas, bem como a justificativa da posse da terra, é possível perceber tal tendência.

Tabela 1 - Distribuição de Sesmarias na capitania do Ceará (1679 - 1824)

\begin{tabular}{|c|c|c|c|c|}
\hline Período & Pecuária & Agricultura & Agricultura + Pecuária & Total \\
\hline $1679-1699$ & 254 & - & 07 & 261 \\
\hline $1700-1709$ & 583 & 00 & 12 & 595 \\
\hline $1710-1719$ & 324 & 02 & 12 & 338 \\
\hline
\end{tabular}

\footnotetext{
182 Data de Sesmaria № 19 - 05 de agosto de 1700 In: TAVARES, João de Lyra. Apontamentos para a história territorial da Parahyba (Requerimentos de sesmarias - 1750-1800). Parayba: Imprensa Official, 1910, p. 42.

183 Idem.

${ }^{184}$ AHU - Rio Grande do Norte, D. 10. 22 de junho de 1667. Requerimento do sargento-mor Pedro Borges Pacheco e do capitão Francisco de Abreu de Lima ao príncipe regente, D. Pedro, pedindo confirmação de carta de sesmaria de terra na Ribeira do Ceará-Mirim, passada pelo governador-geral do Brasil Alexandre de Sousa Freire.
} 


\begin{tabular}{|c|c|c|c|c|}
\hline $1720-1729$ & 383 & 12 & 26 & 421 \\
\hline $1730-1739$ & 300 & 11 & 20 & 331 \\
\hline $1740-1749$ & 212 & 15 & 11 & 238 \\
\hline $1750-1759$ & 50 & 07 & 03 & 60 \\
\hline $1760-1769$ & 06 & - & - & 06 \\
\hline $1770-1779$ & 09 & - & 01 & 10 \\
\hline $1780-1789$ & 12 & 07 & 02 & 21 \\
\hline $1790-1791$ & 28 & 12 & 07 & 47 \\
\hline $1800-1809$ & 12 & 02 & 04 & 18 \\
\hline $1810-1819$ & 47 & 08 & 34 & 89 \\
\hline $1820-1824$ & 26 & 00 & 01 & 27 \\
\hline Sem definição & - & - & - & 10 \\
\hline Total Geral & 2.246 & 76 & 140 & 2.472 \\
\hline
\end{tabular}

FONTE: PINHEIRO, Francisco José. Notas sobre a formação social do Ceará, 1680-1820. Fortaleza: Fundação Ana Lima, 2008. p. 23.

$\mathrm{Na}$ tabela desenvolvida por Francisco José Pinheiro, com dados referentes aos 14 volumes das cartas de sesmaria do Ceará, fica claro que foi a atividade pastoril que possibilitou a ocupação da capitania. A maior parte das sesmarias, cerca de $91 \%$ do total, foi doada com a justificativa de que seria ocupada com a criação de gado. Por outro lado, apenas 76 das 2.472 solicitações tinham como justificativa o uso da terra para o cultivo de gêneros agrícolas. Tal falta de interesse pelos cultivos agrícolas pode ser justificado pelo clima semiárido e solo seco de muitas regiões da capitania, que impossibilitavam certos tipos de cultura, ou as restringiam a regiões mais específicas. Sesmarias concedidas que justificavam o uso da terra tanto para a agricultura como para a pecuária corresponderam a menos de $6 \%$ do total. Com base nesses dados, também é possível perceber o incremento no número de doações entre os anos de 1700 e 1709, período de forte embate entre colonos e nativos, bem como da expansão dos currais para as regiões interioranas.

Características semelhantes foram encontradas nas concessões de sesmarias nos sertões da capitania do Rio Grande do Norte. Na Ribeira do Apodi, no século XVIII, 66\% das solicitações de sesmarias justificavam o uso da terra para a pecuária, 14, $5 \%$ para a criação de gados e o estabelecimento de lavoura, $5 \%$ exclusivamente para o estabelecimento de lavouras, e em $14,5 \%$ a justificativa não foi informada ${ }^{185}$. Em relação a Ribeira do Seridó, $60 \%$ das sesmarias foram solicitadas para criação de gado, $6 \%$ para criação de gados e agricultura, e $4 \%$ somente para a agricultura ${ }^{186}$. Quantitativos semelhantes são encontrados na segunda metade

\footnotetext{
185 SOUZA, Ana Cláudia Bezerra de. O homem e o sertão: a colonização da Ribeira do Apodi no século XVIII. Monografia (Graduação em História) UFRN, Natal, 2007, p. 42. Apud DIAS, Thiago Alves. DINÂMICAS MERCANTIS COLONIAIS: capitania do Rio Grande do Norte (1760-1821). Dissertação ( Mestrado em História) UFRN, Natal, 2011, p. 189.

186 MACÊDO, Muirakytan Kennedy de. Rústicos cabedais: patrimônio e cotidiano familiar nos sertões do Seridó (Séc. XVIII). Tese (Doutorado em Ciências Sociais) - Universidade Federal do Rio Grande do Norte, 2007, p. 72.
} 
do século XVIII na Ribeira do Assú, assim, 54\% das solicitações de sesmarias foram justificadas para criação de gados, $22 \%$ para a criação de gados e o plantio de lavouras, 3\% exclusivamente para o plantio de lavouras, e 5\% para criação de gados, cultivo de lavouras e pesca, as demais não possuíam justificativa.

A relação demonstrada na tabela abaixo foi elaborada em 1798 pelo governador Fernando Delgado de Castilho com o intuito de informar à Coroa o número de sesmarias concedidas pelos governadores da Paraíba $^{187}$. A relação, entretanto, não traz especificações referentes à localização ou as justificativas das sesmarias concedidas, mesmo assim nela é possível perceber o incremento nos números de doações ao longo dos setecentos.

Tabela 2 - Médias anuais de distribuição de Sesmarias na capitania da Paraíba ( 1700

- 1797)

\begin{tabular}{|c|c|}
\hline $\begin{array}{c}\text { Período de } \\
\text { concessão }\end{array}$ & $\begin{array}{c}\mathbf{N}^{\mathbf{0}} \text { de sesmarias } \\
\text { concedidas }\end{array}$ \\
\hline $1700-1702$ & 15 \\
\hline $1703-1708$ & 50 \\
\hline $1709-1717$ & 66 \\
\hline $1717-1719$ & 23 \\
\hline 1719 & 02 \\
\hline $1720-1721$ & 14 \\
\hline $1722-1728$ & 31 \\
\hline $1728-1734$ & 32 \\
\hline $1734-1744$ & 90 \\
\hline 1744 & 09 \\
\hline $1744-1745$ & 09 \\
\hline $1745-1754$ & 81 \\
\hline $1754-1757$ & 69 \\
\hline $1757-1760$ & 94 \\
\hline $1761-1764$ & 63 \\
\hline $1764-1797$ & 448 \\
\hline
\end{tabular}

Fonte: AHU - Paraíba, D. 2447. Paraíba, 10 de setembro de 1798. Carta do governador da Paraíba, Fernando Delgado Freire de Castilho, à rainha, D. Maria, sobre o estado de conservação das matas; e remetendo relação das datas de sesmarias passada pelo governo da Paraíba a partir de 1678.

A partir do estudo das datas de sesmarias distribuídas na Paraíba, reunidas por João de Lyra Tavares em $1910^{188}$, foi possível ter uma visão mais ampla da questão. Foram analisadas 590 solicitações de sesmarias, entre os anos de 1586 e 1762. Nesse conjunto de cartas de sesmarias não foi encontrado nenhum pedido de terras no sertão anterior ao ano de 1700 , da

\footnotetext{
${ }^{187}$ AHU - Paraíba, D. 2447. Paraíba, 10 de setembro de 1798. Carta do governador da Paraíba, Fernando Delgado Freire de Castilho, à rainha, D. Maria, sobre o estado de conservação das matas; e remetendo relação das datas de sesmarias passada pelo governo da Paraíba a partir de 1678.

188 TAVARES, João de Lyra. Para a historia territorial da Parahyba ( Datas de Sesmarias). Paraíba: Imprensa Official, 1910.
} 
mesma forma é possível confirmar o grande aumento de solicitações ao longo século XVIII, uma vez que de um total de 590 requerimentos 571 foram feitos nesse período. Com relação a localização das terras requeridas, cerca de $65,2 \%$ se encontravam no sertão. Sobre os números para Pernambuco, foram analisadas as datas de sesmarias doadas entre os anos de 1729 e 1783, e de um total de 89 datas cerca de $17 \%$ foram de terras sertanejas ${ }^{189}$.

De forma geral, os constantes pedidos de sesmarias para as regiões interioranas de Pernambuco e anexas ao longo do século XVIII são indicativos de que, de fato, estava ocorrendo um aproveitamento produtivo dessas regiões. $\mathrm{O}$ aproveitamento dessas terras, a partir da montagem de fazendas e currais, por sua vez, visava o fornecimento de gêneros que eram escassos tanto nas vilas açucareiras como na região mineradora quando do boom aurífero. $\mathrm{O}$ gado vacum foi um dos principais gêneros consumidos pelas Minas exportados pelas capitanias do Norte, o que impulsionou e expandiu a sua produção na região ${ }^{190}$. Essa crescente demanda por reses justificaria o aumento considerável das solicitações de terras nas porções sertanejas da Capitania Geral de Pernambuco a partir dos setecentos.

Em decorrência desse processo, é possível supor que as regiões agrestinas e sertanejas iam se tornando cada vez mais povoadas, tanto por sesmeiros e rendeiros, como pela mão de obra empregada em currais e lavouras. Nos quadros 2, 3, 4 e 5, tem-se os números relativos à população dos sertões da Capitania Geral de Pernambuco, junto com os números totais de habitantes de cada uma das capitanias, para que se tenha uma ideia da distribuição populacional dessas regiões:

\section{Quadro 2 - População do sertão do Rio Grande do Norte (1774)}

\begin{tabular}{|c|c|c|c|c|c|}
\hline & $\begin{array}{c}\text { Capitania } \\
\text { do Rio } \\
\text { Grande do } \\
\text { Norte }\end{array}$ & $\begin{array}{c}\text { Vila de } \\
\text { Portalegre }\end{array}$ & Assú & Apodi & Pau dos \\
Ferros \\
\hline Total & 23.812 & 713 & 3.530 & 2.292 & 3.236 \\
\hline
\end{tabular}

Fonte: Adaptado a partir de informações contidas em "Ideia da População da Capitania de Pernambuco e de suas anexas”. Coleção Pernambuco (Códices) - Documentos do Acervo de Manuscritos, 11, 03,006, BN

\footnotetext{
189 Biblioteca Pública. Documentação histórica pernambucana (Sesmarias) Recife: Secretaria de educação e cultura, 1955.

190 BONIFÁCIO, Hugo Demétrio Nunes Teixeira. Nas rotas que levam às minas: mercadores e homens de negócios da capitania de Pernambuco no comércio de abastecimento da região mineradora no século XVIII. Tese de doutorado. Recife: UFPE/ CFCH/ PPGH, 2012, p. 71 - 72.
} 
Quadro 3 - População do sertão do Ceará (1774)

\begin{tabular}{|c|c|c|c|c|c|c|c|c|c|}
\hline & $\begin{array}{l}\text { Capitania } \\
\text { do Ceará }\end{array}$ & $\begin{array}{l}\text { Monte } \\
\text { Mor } \\
\text { Velho }\end{array}$ & Arneiroz & Russas & Quixeramobim & $\begin{array}{l}\text { Vila } \\
\text { do } \\
\text { Icó }\end{array}$ & Crato & $\begin{array}{l}\text { Cariris } \\
\text { Novos }\end{array}$ & Inhamuns \\
\hline \multirow[t]{2}{*}{ Total } & 6.1408 & 348 & 6.012 & 7.359 & 2.622 & 8.564 & 3.156 & 4.078 & 4.210 \\
\hline & Sobral & $\begin{array}{c}\text { Serra } \\
\text { dos } \\
\text { Cocos }\end{array}$ & & & & & & & \\
\hline Total & 6.207 & 5.343 & & & & & & & \\
\hline
\end{tabular}

Fonte: Adaptado a partir de informações contidas em "Ideia da População da Capitania de Pernambuco e de suas anexas”. Coleção Pernambuco (Códices) - Documentos do Acervo de Manuscritos, 11, 03,006, BN

Quadro 4 - População do sertão de Pernambuco (1774)

\begin{tabular}{|l|l|l|l|l|l|l|}
\hline & $\begin{array}{l}\text { Capitania de } \\
\text { Pernambuco }\end{array}$ & $\begin{array}{l}\text { São } \\
\text { Francisco das } \\
\text { Chagas }\end{array}$ & Simbres & Cabrabó & Tacaratu & Exú \\
\hline Total & 229.743 & 4.873 & 1.140 & 4.960 & 1.949 & 166 \\
\hline
\end{tabular}

Fonte: Adaptado a partir de informações contidas em "Ideia da População da Capitania de Pernambuco e de suas anexas”. Coleção Pernambuco (Códices) - Documentos do Acervo de Manuscritos, 11, 03,006, BN

Quadro 5 - População do sertão da Paraíba (1774)

\begin{tabular}{|l|l|l|l|l|l|}
\hline & $\begin{array}{l}\text { Capitania da } \\
\text { Paraíba }\end{array}$ & Cariri Velho & $\begin{array}{l}\text { Vila Nova da } \\
\text { Rainha }\end{array}$ & $\begin{array}{l}\text { Vila de } \\
\text { Pombal }\end{array}$ & Seridó \\
\hline Total & 52.468 & 3.199 & 2.489 & 7.711 & 3.630 \\
\hline
\end{tabular}

Fonte: Adaptado a partir de informações contidas em "Ideia da População da Capitania de Pernambuco e de suas anexas”. Coleção Pernambuco (Códices) - Documentos do Acervo de Manuscritos, 11, 03,006, BN

Com base nesses dados é possível perceber que os sertões das capitanias de Pernambuco e anexas já se encontravam bem explorados e povoados no terceiro quartel do século XVIII. O percentual dos habitantes das vilas sertanejas em relação ao número total da população de cada capitania era de $41 \%$ no Rio Grande do Norte, $78 \%$ no Ceará, $6 \%$ em Pernambuco ${ }^{191}$ e cerca de $32 \%$ na Paraíba. Assim, diante de um número total de 367.431 habitantes em Pernambuco e anexas, cerca de $24 \%$ ocupavam as regiões interioranas, sertanejas.

${ }^{191}$ Com relação ao baixo percentual da população sertaneja pernambucana diante do número total, é importante salientar que Pernambuco possuía áreas de grande adensamento populacional na faixa litorânea, e só as regiões imediatas ao porto do recife possuíam um numero de 43000 moradores. AHU - Avulsos de Pernambuco, D. 9665. Recife, 30 de setembro de 1777. Ofício do Governador, José Cesar de Meneses ao secretário de estado da Marinha e Ultramar, Martinho de Melo e Castro, remetendo o mapa da enumeração dos povos da dita capitania. 
Seguindo o rastro do gado, as fronteiras foram expandidas rumo ao interior do território colonial ao longo do século XVIII. A abertura de novas fronteiras e as suas possibilidades produtivas, levaram a um deslocamento de contingentes populacionais do litoral rumo ao sertão, e paralelamente ao enfrentamento e genocídio dos nativos, essas regiões foram pouco a pouco povoadas através da distribuição de terras. Foi assim, seguindo o rastro do gado, que grandes contingentes populacionais se deslocaram e passaram a ocupar as regiões climaticamente instáveis dos sertões de Pernambuco e anexas nos setecentos.

\section{A mandioca como base do regime alimentar}

Segundo Sidney Mintz, boa parte das sociedades predominantemente agrícolas tiveram como base alimentar um carboidrato complexo em particular. Nessas sociedades, a população era, então, nutrida pela conversão corporal desses carboidratos, fornecidos por um ou dois tipos de grãos ou tubérculos, em açucares, que podiam ser ingeridos isoladamente ou combinados com leguminosas, como o feijão. Outros ingredientes importantes em termos nutritivos também eram consumidos, como verduras, carnes, peixes, aves e condimentos, mas eram vistos como secundários pela população, alimentos adicionais ao amido principal ${ }^{192}$. Essa combinação de suplementos de sabor adicional e carboidratos complexos teria sido uma característica fundamental da alimentação de sociedades agrícolas.

Na primeira metade do século XIX, um estudioso da agricultura brasileira escrevia que “até agora, nenhum vegetal cultivado mereceu ainda uma preferência nacional decidida, e foi adotado por base de toda a comida, como acontece em quase toda a Europa, onde se adotou o pão, e no oriente e os povos asiático onde se adotou o arroz". Apesar de admitir a não existência de uma preferência unificada, Taunay apontou que cada região possuía um ingrediente base no seu regime alimentar cotidiana, assim "na beira-mar prefere-se a farinha de mandioca, que os sertanejos inclinam-se ao milho, que os maranhenses e paraenses antepõem o arroz" ${ }^{193}$.

Nas capitanias de Pernambuco e anexas o alimento que ocupou essa posição de protagonismo na dieta da população foi a mandioca. A relativa abundância de fontes e relatos sobre a farinha derivada da raiz, sua produção e comercialização refletem sua importância fundamental na região. A mandioca, para o fabrico da farinha, era de longe a lavoura de

\footnotetext{
192 MINTZ, Sidney W. Sweetness and Power. The place of sugar in modern history. New York: Penguin Group, 1985, p. 9.

193 TAUNAY, Carlos Augusto. O manual do agricultor brasileiro. São Paulo: Cia das Letras, 2001, p.76
} 
subsistência mais amplamente cultivada, e a farinha era um componente indispensável da dieta alimentar das capitanias do norte.

A mandioca é um arbusto com raízes tuberosas, sua parte mais utilizada, com casca pardacenta e massa branca. Segundo Câmara Cascudo, o termo mandioca significaria "casa de Mani” em tupi, ${ }^{194}$ em referência a uma antiga lenda sobre o surgimento do vegetal. Esse arbusto já era conhecido e cultivado pelos indígenas desde antes da chegada dos portugueses, e em 1587 Gabriel Soares de Souza já anotava o que via sobre a mandioca, e a lida dos nativos no cultivo da mandioca e na produção da sua farinha. Segundo Souza,

para se aproveitarem os índios e mais gente destas raízes, depois de arrancadas rapam-nas muito bem até ficarem alvíssimas, o que fazem com cascas de ostras, e depois de lavadas ralam-nas em uma pedra ou ralo, que para isso têm, e, depois de bem raladas, espremem esta massa em um engenho de palma, a que chamam tapeti, que lhe faz lançar a água que tem tôda fora, e fica essa massa toda muito enxuta, da qual se faz a farinha que se come ${ }^{195}$

A lavoura da mandioca para a produção de farinha foi logo disseminada entre os colonos, uma vez que seu cultivo apresentava algumas particularidades positivas, e consideradas importantes pelos lavradores. A planta não necessitava de terras férteis, com uma boa adaptação a diferentes tipos de solos, e era bastante resistente a seca, sendo considerado um roçado de terra firme, que não necessitava ser cultivado na beira de rios e locais úmidos ${ }^{196}$. Ela também era considerada de fácil manejo, com um plantio feito em valas, ou em covas, abertas com as próprias mãos, quando o solo era mais solto, ou com um único golpe de enxada. A colheita também poderia ser feita sem o uso de ferramentas, se a terra estivesse ligeiramente úmida. Além disso, o tubérculo não requeria a separação ou compra de sementes para a colheita seguinte, bastando apenas guardar umas ramas de mandioca para o plantio. A este respeito, Rocha Pitta apontou que

esta planta com huns ramos, ou garfos, que em qualquer tempo (exepto nos meses de abril, mayo e junho, que são do mais rigoroso inverno) se metem na terra, chamados Maníbas, os quaes lanção grossas raízes ${ }^{197}$.

Essas manibas, também chamadas de manivas, eram feitas a partir do tronco do arbusto, cortado em pedaços de mais ou menos um palmo ${ }^{198}$. Após esse processo, eram cavadas covas

\footnotetext{
${ }^{194}$ CASCUDO, Luís da Câmara. Dicionário do folclore brasileiro. Rio de Janeiro: Ediouro, s/d, p. 380.

${ }^{195}$ SOUZA, Gabriel Soares de. Tratado descritivo...op. cit, p. 174.

${ }^{196}$ OLIVEIRA, Marcelo Almeida. As roças brasileiras, do período colonial à atualidade. Caracterização histórica e formal de uma categoria tipológica. VARIA HISTORIA, Belo Horizonte, vol.28, n 48, jul/dez, 2012, p. 767-768.

${ }^{197}$ PITA, Sebastião da Rocha. História da América Portugueza. Bahia: Imprensa Econômica, 1878, p 16.

198 AHU - Avulsos de Pernambuco, D. 13809 . Recife, 14 de maio de 1798. Ofício do governador da capitania de Pernambuco, D. Tomás José de Melo, ao secretário de estado da marinha e ultramar, D. Rodrigo de Sousa
} 
redondas, e em cada uma eram enterradas entre três e quatro manivas, cobertas pela terra até o meio ${ }^{199}$. Depois de cerca de quatro dias, o seu caule começava a se desenvolver, e crescia "até dez e doze palmos, formando huns nós nos lugares, onde as folhas, que imitam a mão de homem com os dedos bem abertos" 200 . Dependendo da sua qualidade, a mandioca amadurecia no período de seis a dezesseis meses do seu plantio, podendo ser colhida a qualquer tempo ou deixada armazenada na própria terra, sem apodrecer. Ao ser puxado do solo, o arbusto trazia consigo cerca de meia dúzia de raízes ${ }^{201}$.

Depois de colhidas, as raízes eram quebradas, colocadas em cestos, e dava-se então início ao processo de produção da farinha. Gabriel Soares de Souza anotou bem o como era o processo desenvolvido pelos indígenas:

Para se fazer a farinha destas raízes se lavam primeiro muito bem, e depois, desfeitas a mão, se espremem no tapeti, cuja água não faz mal; depois de bem espremidas desmancham esta massa sobre uma urupema, que é como joeira, por onde se coa o melhor, e ficam os caroços em cima e o pó que se coou lançam-no em um alguidar que está sobre o fogo, aonde se enxuga e coze da maneira que fica dito, e fica como cuscuz, a qual em quente e em fria é muito boa e assim no sabor como em ser sadia e de boa digestão ${ }^{202}$.

Rica em ácido cianídrico, substância que em excesso podia causar a morte, a raiz perdia toda a sua toxidade através de processos de cozimento e torrefação, podendo ser consumida na forma de farinha ${ }^{203}$. Em finais do século XVIII o processo já se encontrava um pouco mais aprimorado, e fazia-se uso de uma roda e um ralo de cobre, movidos por uma manivela de ferro, que pressionavam a raiz até moê-la. A raiz moída ia, então, para uma prensa, onde era retirado todo o seu veneno. De lá a massa era colocada em um forno de cobre, ferro ou tijolos em fogo baixo, e ali era mexida com um "rodo de pao até ficar em farinha solta bem torrada capaz de se comer e de guardar e durar bem neste estado dois e três annos"204. A farinha fresca da mandioca

Coutinho, sobre as recomendações para se usar bois e arados para cultivar as terras, enviando uma breve descrição dos métodos do cultivo da terra e manipulação dos gêneros que se exportam daquela capitania.

${ }^{199}$ Por entre os roçados de mandioca também eram plantados outros gêneros alimentícios, como o feijão, que não necessitava de muito espaço para se desenvolver e possuía um curto ciclo de amadurecimento, de cerca de três meses.

${ }^{200}$ AHU - Avulsos de Pernambuco, D. 13809 . Recife, 14 de maio de 1798. Ofício do governador da capitania de Pernambuco, D. Tomás José de Melo, ao secretário de estado da marinha e ultramar, D. Rodrigo de Sousa Coutinho, sobre as recomendações para se usar bois e arados para cultivar as terras, enviando uma breve descrição dos métodos do cultivo da terra e manipulação dos gêneros que se exportam daquela capitania.

${ }^{201}$ Idem

${ }^{202}$ SOUZA, Gabriel Soares de. Tratado descritivo...op. cit, p. 187.

${ }^{203}$ Ibidem, p. 187.

${ }^{204}$ AHU - Avulsos de Pernambuco, D. 13809 . Recife, 14 de maio de 1798. Ofício do governador da capitania de Pernambuco, D. Tomás José de Melo, ao secretário de estado da marinha e ultramar, D. Rodrigo de Sousa Coutinho, sobre as recomendações para se usar bois e arados para cultivar as terras, enviando uma breve descrição dos métodos do cultivo da terra e manipulação dos gêneros que se exportam daquela capitania. 
não suportava mais do que dois dias sem apodrecer, por outro lado, a farinha seca, também chamada de farinha de guerra, prestava-se à estocagem e durava por muito mais tempo ${ }^{205}$.

Apesar do relativamente longo processo de extração do veneno e do cozimento da farinha, as vantagens do cultivo da mandioca como principal gênero de subsistência eram sabidas. Sobre isso, uma carta escrita por José da Silva Lisboa em 1781 sobre as características gerais da capitania da Bahia e as suas principais culturas pode ser bastante elucidativa. Nela o advogado apontava que a facilidade do seu cultivo era tamanha que cada escravo "sem dificuldade prepara e planta todos os dias 100 covas de mandioca". Além disso, segundo Lisboa, as terras de solo menos fértil conseguiam produzir cerca de 20 alqueires de farinha por cada mil covas plantadas. Dessa forma, dois escravos juntos "teriam feito em 10 dias planta para 40 alqueires", e em "outros 10 dias teriam colhido e preparado a farinha com o trabalho reunido",206.

Além da farinha, outros subprodutos da mandioca amplamente consumidos eram o carimã (uma espécie de fácula, polvilho, usada para fazer "muito bom pão, e bolos amassados com leite e gemas de ovos" ${ }^{207}$ ), o beiju (massa de mandioca ralada e peneirada, cozida), a tapioca (polvilho torrado a fogo brando) e a puba ( mandioca fermentada em água). Ademais, existiam outras espécies de mandioca, chamadas mandioca-mansa, também conhecidas como aipins ou macaxeiras, que apesar de não possuírem elevados índices de ácido cianídrico, eram inadequadas para a fabricação dos produtos acima citados, mas serviam especialmente assadas ou cozidas ${ }^{208}$.

Tendo em vista a facilidade do seu cultivo, a variedade de seu uso, e a durabilidade da sua farinha, a mandioca e seus derivados serviam muito bem para o aprovisionamento das populações das áreas rurais e urbanas, o municiamento das tropas, a alimentação dentro da grande lavoura, bem como na alimentação de marinheiros e escravos que atravessavam o atlântico ${ }^{209}$. Juntamente com a mandioca, o arroz, o milho, o feijão e outros variados legumes também eram cultivados, mas em proporções diferentes, ocupando um papel secundário na alimentação cotidiana diante do consumo da raiz e dos seus derivados. Para uma melhor

\footnotetext{
205 AGUIAR, Pinto de. Mandioca: o pão do Brasil. Rio de Janeiro: Civilização Brasileira, 1982, p. 34.

206 ABNRJ, nº XXXII. Bahia, 18 de outubro de 1781. Carta de José da Silva Lisboa para o Doutor Domingos Vandell, Diretor do Real Jardim Botânico de Lisboa, em que lhe dá notícia desenvolvida sobre a Bahia.

${ }^{207}$ SOUZA, Gabriel Soares de. Tratado descritivo...,op. cit, p. 179.

208 TAUNAY. Manual do Agricultor...Op. cit. p. 153 - 154.

${ }^{209}$ ALENCASTRO, Luiz. O trato dos viventes: formação do Brasil no Atlântico Sul. São Paulo: Companhia das Letras, 2000. p. 252.
} 
compreensão da produção desses gêneros dentro dos limites das capitanias de Pernambuco e anexas, nas próximas páginas buscou-se traçar um desenho do sistema alimentar da região.

\section{A produção de alimentos nas capitanias de Pernambuco e anexas na segunda metade do século XVIII}

Identificar as principais regiões produtoras de alimentos nos setecentos não consiste em uma tarefa de grande facilidade, tendo em vista a característica própria do empreendimento colonial, e a sua principal preocupação com a manutenção do complexo agroexportador. Nesse sentido, a agricultura voltada para o abastecimento interno era vista como uma espécie de retaguarda da principal atividade colonial, para a Coroa e os agentes da colonização, que era a produção de gêneros que interessassem ao comércio metropolitano. Assim, os produtores desses gêneros nem sempre são mencionados de forma direta na documentação, e as lavouras de primeira necessidade muitas vezes só são referenciadas em momentos de crise nas suas produções.

Além disso, o território que compreende as capitanias de Pernambuco e anexas, ou seja, Pernambuco, Paraíba, Rio Grande do Norte e Ceará, além de extenso, é heterogêneo, abarcando tanto regiões cuja atividade produtiva é predominantemente pastoril bem como zonas voltadas para a plantation açucareira. Nesse sentido, a produção de gêneros de primeira necessidade se desenvolveu adequando-se às especificidades regionais, tanto de caráter natural como socioeconômicas.

Em Pernambuco, a falta de interesse da grande lavoura canavieira em produzir excedentes e até mesmo alimentos para o seu próprio abastecimento ${ }^{210}$, optando por dedicar sua força produtiva aos gêneros mais demandados pelos circuitos mercantis, e sua consequente dependência do mercado local de alimentos, teriam moldado toda a produção de gêneros de primeira necessidade nas imediações da plantation ao longo dos setecentos. Palácios aponta que a prática de produtores de açúcar e plantadores de canas adquirirem alimentos fora de suas plantações parece ter sido mais habitual que a autossuficiência estrutural da grande lavoura ${ }^{211}$. Assim, em inícios dos setecentos parte considerável da produção de alimentos já era originada de pequenas e médias unidades escravista especializadas. Entretanto, a queda dos preços do açúcar nos primeiros decênios do século XVIII também teriam envolvido essas unidades na crise em virtude dos seus maiores níveis de capitalização, que lhes permitiam explorar o

\footnotetext{
${ }^{210}$ Esse assunto será mais bem trabalhado no tópico seguinte.

${ }^{211}$ PALACIOS, Guillermo. Campesinato e escravidão no Brasil: Agricultores livres e pobres na Capitania Geral de Pernambuco (1700-1817). Brasília: Editora UnB, 2004, p . 62.
} 
trabalho escravo. A saída de cena de boa parte destas unidades de produção escravista de alimentos teria justificado o surgimento de uma agricultura camponesa ${ }^{212}$ composta por agricultores livres e pobres, que ao longo do século XVIII se tornaram importantes produtores de gêneros de primeira necessidade.

Nas regiões em que a plantation pernambucana prevalecia, esses produtores de alimentos teriam cultivado suas lavouras em regiões carentes de maior atrativo para o sistema agrário hegemônico, mas que se encontravam relativamente próximas das zonas de produção açucareira, como as zonas produtoras das Freguesias de Pau d'alho, Santo Amaro do Jaboatão, e da Vila de Goiana. A freguesia de Pau d'alho, localizava-se no centro de uma área altamente dinamizada pela produção canavieira, nas suas vizinhas Nazaré e São Lourenço, e se tornou uma das grandes expoentes da produção de alimentos na capitania de Pernambuco, onde se produzia "toda sorte de lavouras" e todas as semanas acontecia uma feira de "comércio de todos os gêneros da terra" 213. Da mesma forma, nas proximidades do aglutinado urbano do Porto do Recife, a freguesia de Santo Amaro do Jaboatão também foi referida como uma produtora de alimentos na região. Segundo o governador José César de Menezes, nessa freguesia os “plebeus vivem de seus negócios, e plantarem lavouras, arrozes, algodão e mandioca" ${ }^{214}$. A Vila de Goiana, por sua vez, altamente dinamizada por uma feira de gados "que dessem do certão", teria se configurado como um dos grandes centros produtores de farinha da mata e litoral pernambucanos, tal fato pode ser percebido pela constante atenção dedicada pelas autoridades ao cultivo de mandioca no termo da vila ${ }^{215}$ e através dos pedidos constantes para que se enviassem ao Recife "toda a farinha do termo que estiver pronta"216. Ademais, também no

\footnotetext{
${ }^{212}$ É importante apontar que a historiografia brasileira constantemente se refere às unidades domésticas de produção como camponesas, mesmo que haja uma pequena presença de escravos no seu interior. Entretanto, esse conceito implica algumas características que são indispensáveis para a sua aplicação, não podendo ser reduzido a apenas algumas delas. Desta forma, os pequenos produtores livres que se desenvolveram em torno das zonas de exportação escravista não constituíram um campesinato em seus moldes originais. Optamos, então, por nos referir a este grupo como "roceiros" e "lavradores de mandioca", nomenclaturas encontradas na documentação por nós trabalhada. A respeito desta discussão ver: LOPES, Gustavo Acioli. O saco de batatas colonial? Considerações sobre o uso do conceito de campesinato na historiografia do Brasil Colônia. Clio (Recife), v. 1, p. 46-65, 2011.

${ }^{213}$ AHU - Avulsos de Pernambuco. D. 11530. Recife, 30 de agosto de 1787. Ofício do ouvidor da capitania de Pernambuco, Antônio Xavier Moraes Teixeira Homem, ao secretário de estado da Marinha Ultramar, Martinho de Melo e Castro, sobre a situação da justiças nos julgados da comarca de Olinda, Garanhuns, Tacaratu e Cabrobó, e sugerindo a elevação de todas à vila, e informando o desenvolvimento comercial de Paudalho e de Santo Antão da Mata, e a necessidade de transforma-las em vilas.

214 "Ideia da População da Capitania de Pernambuco e de suas anexas". Coleção Pernambuco (Códices) Documentos do Acervo de Manuscritos, 11, 03,006, BN.

${ }^{215}$ Entre 1788 e 1789 o governador Dom Tomás José de Mello solicitou por três vezes que o capitão mor da vila elaborasse uma relação com as culturas que se achavam plantadas e as colheitas realizadas no termo.

${ }^{216}$ APEJE - Ofícios do Governo (4), Fls.52- 53v. S/d, 1788, Pernambuco. Carta do governador Dom Thomas José de Melo, para o capitão mor da Vila de Goiana. Sobre a ordem de se plantar mandioca, e também a respeito dos mapas que devem ser feitos sobre a agricultura.
} 
termo da Vila de Goiana, é mencionada uma "Aldeia de Paizanos", que vivia "de plantar mandiocas, fabricarem farinhas e conduzirem-nas para a Praça do Recife" ${ }^{217}$.

Nos sertões, onde predominava a atividade pastoril, a lavoura de alimentos teve que adaptar-se às particularidades do terreno para atender às demandas das populações sertanejas. Nesse sentido, Manuel Correia de Andrade aponta que a agricultura no sertão se instalou "nos locais mais úmidos, mais favoráveis, onde os solos eram mais espessos, como os leitos dos rios e lagoas secas" ${ }^{218}$. Além da chamada agricultura de vazante mencionada por Correia de Andrade, as lavouras também ocupavam os brejos agrestinos e as "serras frescas", que funcionavam como "ilhas" de umidade nas vastidões das caatingas. No sertão pernambucano, é possível observar a exploração da potencialidade de cultivo dessas "ilhas" na Freguesia de Cabrobó, que em informação de 1774 compreendia "em si sessenta fazendas de gado vacum e cavalar e (...) nos brejos plantão algumas lavouras para se manterem", e na Freguesia do Ararobá , no sertão de Garanhuns, onde nos seus "brejos plantão lavouras, milhos, feijoens,

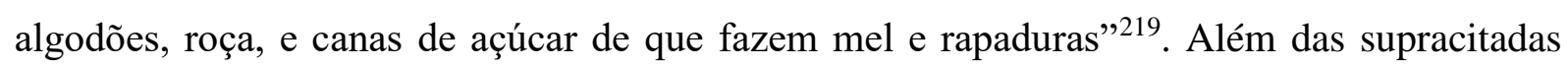
freguesias, nas vilas de índios de Cimbres e de Águas Belas, segundo José César de Menezes, seus habitantes também plantavam "algumas lavouras para seu sustento" ${ }^{220}$.

Em relação ao cultivo de alimentos na capitania da Paraíba na segunda metade do século XVIII, os dados são mais completos que os pernambucanos e permitem uma ampla visão a respeito dos quantitativos da produção. Graças aos mapas de povoação, exportação e aos mapas comparativos entre produção, consumo e exportação elaborados nos anos finais dos setecentos, é possível ter uma melhor percepção sobre o que cada freguesia e vila paraibana produziam. No quadro 6, estão dispostos os principais gêneros de exportação da capitania, juntamente com os seus portos de destino.

\footnotetext{
217 “Ideia da População da Capitania de Pernambuco e de suas anexas”. Coleção Pernambuco (Códices) Documentos do Acervo de Manuscritos, 11, 03,006, BN.

${ }^{218}$ ANDRADE, Manuel Correia de. A Terra e o Homem no Nordeste. Recife: Editora universitária UFPE: , 1998, p. 174.

${ }^{219}$ Ideia da População da Capitania de Pernambuco e de suas anexas". Coleção Pernambuco (Códices) Documentos do Acervo de Manuscritos, 11, 03,006, BN.

${ }^{220}$ Ideia da População da Capitania de Pernambuco e de suas anexas”. Coleção Pernambuco (Códices) Documentos do Acervo de Manuscritos, 11, 03,006, BN
} 
Quadro 6 - Mapa de exportação de produtos da capitania da Paraíba do Norte no ano de 1798

\begin{tabular}{|c|c|c|c|c|c|c|c|c|c|c|c|c|c|}
\hline $\begin{array}{l}\text { Portos para } \\
\text { onde foram }\end{array}$ & $\begin{array}{l}\text { Açúcar } \\
\text { (quintais) }\end{array}$ & $\begin{array}{l}\text { Algodão } \\
\text { (quintais) }\end{array}$ & $\begin{array}{c}\text { Goma } \\
\text { (quintais) }\end{array}$ & $\begin{array}{l}\text { Couros } \\
\text { (número) }\end{array}$ & $\begin{array}{c}\text { Sola } \\
\text { (número) }\end{array}$ & $\begin{array}{l}\text { Vaquetas } \\
\text { (número) }\end{array}$ & $\begin{array}{c}\text { Arroz } \\
\text { (alqueire) }\end{array}$ & $\begin{array}{l}\text { Farinha } \\
\text { (alqueire) }\end{array}$ & $\begin{array}{c}\text { Feijão } \\
\text { (alqueire) }\end{array}$ & Milho & $\begin{array}{c}\text { Peixe } \\
\text { seco } \\
\text { (centos) }\end{array}$ & $\begin{array}{c}\text { Gado } \\
\text { Vacum } \\
\text { (cabeça) }\end{array}$ & $\begin{array}{l}\text { Gado } \\
\text { Cavalar } \\
\text { (cabeça) }\end{array}$ \\
\hline Lisboa & 5320 & 1725 & 10 & 420 & 300 & 174 & & & & & & & \\
\hline Pernambuco & 3236 & 11127 & 22 & 2046 & 492 & 520 & 516 & 1050 & 210 & 50 & 150 & 632 & 65 \\
\hline Rio Grande & & & & & & & & 226 & & & & & 2 \\
\hline Ceará & & & & & & & & & & & & & 3 \\
\hline
\end{tabular}

Fonte: Elaboração da autora a partir de informações do AHU - Paraíba, D. 2510. Paraíba, 31 de julho. Ofício do governador da Paraíba Fernando Delgado Freire de Castilho, ao secretário de Estado da Marinha e Ultramar, Rodrigo de Sousa Coutinho, remetendo mapas gerais relativos aos preço, à exportação, à importação, ao movimento marítimo, à população, aos nascimentos, casamentos, mortes e à ocupação dos habitantes da Paraíba, no ano de 1798 . 
Como se pode observar no quadro 6, juntamente com o açúcar, o algodão e os couros, configuraram-se entre os produtos de exportação da Paraíba variados gêneros de primeira necessidade. Com relação aos derivados da mandioca, ao todo foram exportados 32 quintais, cerca de uma tonelada e meia, de goma para os Portos de Pernambuco ${ }^{221}$ e Lisboa, e 1.276 alqueires de farinha para os portos de Pernambuco e Rio Grande do Norte. Além disso, foram enviados para o porto de Pernambuco 516 alqueires de arroz, 210 alqueires de feijão e 50 alqueires de milho. Boa parte dos gêneros de primeira necessidade exportados teria procedido dos excedentes de lavouras situadas na mesorregião da mata paraibana.

Em 1798 a capitania da Paraíba produziu 185.406 alqueires de farinha dos quais cerca de $68 \%$ foram produzidos nas vilas e freguesias da mata ${ }^{222}$. A paróquia da Paraíba do Norte, cuja sede era a Cidade da Paraíba, e as vilas de índios de Alhandra, Conde e de São Miguel, situadas entre engenhos e plantations, configuraram-se como os principais centros produtores de excedentes de alimentos da capitania. A Paróquia da Paraíba do Norte exportou cerca de 1000 alqueires de farinha, 500 alqueires de arroz e 150 alqueires de feijão. No mesmo ano, a vila de índios do conde, produziu um excedente de 3000 alqueires de farinha, e da também vila de índios de Alhandra foram comercializados 500 alqueires de farinha juntamente com 20 alqueires de milho. A Vila de São Miguel, situada no litoral norte paraibano, por sua vez, foi responsável pela exportação de 226 alqueires de farinha para o Assú, sertão da capitania do Rio Grande do Norte ${ }^{223}$. Cruzando os dados gerais de exportação da capitania, vistos no quadro 6, com as informações sobre os montantes de alimentos que saíram das principais zonas produtoras, percebe-se que nem toda produção excedente era exportada para fora da capitania. Dessa forma, presume-se que essas produções visavam atender as próprias demandas paraibanas, abastecendo áreas que não produziam alimentos suficientes para o próprio consumo, centros urbanos, como o da Cidade da Paraíba, vilas e freguesias circunvizinhas a zonas produtoras, e até mesmo regiões mais distantes, com o sertão.

\footnotetext{
${ }^{221}$ É importante salientar que os produtos encaminhados para o Porto de Pernambuco não eram necessariamente consumidos na capitania de destino, pois enquanto Porto principal, os gêneros que lá chegavam podiam seguir para outras regiões do mundo.

${ }^{222}$ do AHU - Paraíba, D. 2510. Paraíba, 31 de julho. Ofício do governador da Paraíba Fernando Delgado Freire de Castilho, ao secretário de Estado da Marinha e Ultramar, Rodrigo de Sousa Coutinho, remetendo mapas gerais relativos aos preço, à exportação, à importação, ao movimento marítimo, à população, aos nascimentos, casamentos, mortes e à ocupação dos habitantes da Paraíba, no ano de 1798

${ }^{223}$ do AHU - Paraíba, D. 2510. Paraíba, 31 de julho. Ofício do governador da Paraíba Fernando Delgado Freire de Castilho, ao secretário de Estado da Marinha e Ultramar, Rodrigo de Sousa Coutinho, remetendo mapas gerais relativos aos preço, à exportação, à importação, ao movimento marítimo, à população, aos nascimentos, casamentos, mortes e à ocupação dos habitantes da Paraíba, no ano de 1798
} 
De forma semelhante à agricultura sertaneja desenvolvida em Pernambuco, a população do sertão da Paraíba também cultivou suas lavouras nas "ilhas" de umidade do semiárido, como os brejos e as serras úmidas. Região intermediária entre a zona açucareira e a Borborema, o brejo paraibano possuía uma extensa cobertura vegetal, pouco propícia para a criação de gado, mas favorável ao cultivo de lavouras. A este respeito, a solicitação de data de sesmaria feita por um capitão-mor do sertão em 1701 pode ser bastante elucidativa. No pedido o suplicante informava a dificuldade de se abastecer de farinha necessária as guarnições que combatiam os indígenas no sertão, "por não serem capazes de as produzir as terras, que estão povoadas nos ditos sertões". Diante disso, solicitava terras de brejo que havia descoberto na serra Bodopitá, alegando que "nesses brejos e matas que nela há lhe parecem capazes de produzir roças e outros legumes necessários para a conservação com mais cômodo, não só da guerra contra o tapuio, mas também dos moradores do dito sertão" 224 .

No quadro 7 constam os números da produção de alimentos no sertão da capitania da Paraíba em alqueires no ano de 1798, e nele constata-se que as freguesias que mais produziram gêneros de primeira necessidade se encontravam na região do brejo paraibano, as duas últimas do quadro. As lavouras de Bananeiras produziram um total de 10.873 alqueires de alimentos no ano de 1798, e mesmo com a maior parte da produção direcionada para o consumo do próprio termo, teriam restado para a exportação 10 alqueires de goma de mandioca, 30 alqueires de farinha, 45 alqueires de feijão e 22 alqueires de milho, conforme constam nos mapas. Também situada no brejo paraibano, a Vila Nova da Rainha chegou a produzir 11.200 alqueires de farinha, para o consumo da vila e seus termos. Mesmo sem escoar grandes excedentes, somadas, as produções de farinha de mandioca do brejo paraibano corresponderam a cerca de $10,6 \%$ do total produzido na capitania naquele ano.

Quadro 7 - Produção de gêneros de primeira necessidade no sertão da capitania da Paraíba no ano de 1798.

\begin{tabular}{|l|c|c|c|c|}
\hline & Farinha & Feijão & Milho & Arroz \\
\hline $\begin{array}{l}\text { Ribeira do Patú, } \\
\text { Paróquia da Vila } \\
\text { de Pombal }\end{array}$ & 200 & 100 & 150 & 200 \\
\hline $\begin{array}{l}\text { Ribeira do Piancó, } \\
\text { Paróquia da Vila } \\
\text { de Pombal }\end{array}$ & 100 & 110 & 150 & 200 \\
\hline $\begin{array}{l}\text { Ribeira das } \\
\text { Espinharas }\end{array}$ & 50 & 6 & - & 5 \\
\hline
\end{tabular}

${ }^{224}$ Data de Sesmaria No 32 - 02 de outubro de 1702 In: TAVARES, João de Lyra. Apontamentos para a história territorial da Parahyba (Requerimentos de sesmarias - 1750-1800). Parayba: Imprensa Official, 1910, p. 42. 


\begin{tabular}{|l|c|c|c|c|}
\hline $\begin{array}{l}\text { Ribeira do Sabugi, } \\
\text { Paróquia da Vila } \\
\text { da Patos }\end{array}$ & 396 & 52 & 90 & 5 \\
\hline Rio do Peixe & 700 & 326 & 600 & 150 \\
\hline Vila de Pombal & 49 & - & - & - \\
\hline Cariri Velho & - & - & - & - \\
\hline $\begin{array}{l}\text { Ribeira das } \\
\text { Piranhas, Paróquia } \\
\text { da Vila de Pombal }\end{array}$ & - & - & - & 348 \\
\hline Bananeiras Nava da & 11.200 & 781 & 1.536 & - \\
\hline $\begin{array}{l}\text { Vila Nova } \\
\text { Rainha }\end{array}$ & & 757 & 937 & \\
\hline
\end{tabular}

Unidade: Alqueire. Fonte: Elaboração da autora a partir de informações do AHU - Paraíba, D. 2510. Paraíba, 31 de julho. Ofício do governador da Paraíba Fernando Delgado Freire de Castilho, ao secretário de Estado da Marinha e Ultramar, Rodrigo de Sousa Coutinho, remetendo mapas gerais relativos aos preços, à exportação, à importação, ao movimento marítimo, à população, aos nascimentos, casamentos, mortes e à ocupação dos habitantes da Paraíba, no ano de 1798 .

No mesmo quadro 7 nota-se que as demais regiões do sertão, mais interiorizadas e de clima mais árido, predominantemente pastoris, tiveram uma produção bastante inferior às áreas de brejo durante o mesmo ano. As produções das ribeiras do sertão e da vila de Pombal, segundo os mapas de produção e consumo, não geraram excedentes, e todos os gêneros alimentícios produzidos nos seus termos serviram para autoconsumo, o que não significa, necessariamente, que tenham sido suficientes para atender as demandas da população. Em relação ao Cariri Velho e a Ribeira das Piranhas da Vila de Pombal, em seus mapas não constam gêneros oriundos de lavouras de primeira necessidade. Diante dessa baixa produção de alimentos, supõe-se que as freguesias sertanejas, excetuando-se as que se situavam no brejo paraibano, provavelmente teriam dependido do abastecimento de outras localidades para atender as demandas das suas populações. Como esses dados são de 1798, é importante salientar que o cultivo de gêneros de primeira necessidade ainda poderia estar sofrendo as consequências da grande seca que atingiu os sertões entre os anos de 1791 e 1793. No ano de 1800, as produções teriam sido consideravelmente maiores. O Cariri Velho, que não havia produzido farinha de acordo com o mapa anterior, nesse ano teria produzido 1.000 alqueires. Já a vila de Pombal, cujas produções de farinha somadas em 1798 tinham alcançado o montante de 349 alqueires, em 1800 chegou a produzir 1433 alqueires. Mesmo assim levando em conta a população das duas vilas, de 2.285 e 2.244 habitantes respectivamente, e fazendo um comparativo com as demais regiões, as suas produções ainda podem ser consideradas baixas. Diante desses números, não é possível afirmar a autossuficiência alimentar das vilas do sertão da capitania da Paraíba, excetuando-se as áreas dos brejos. 
O desenho do sistema de produção de alimentos na capitania do Rio Grande do Norte teria se assemelhado bastante ao paraibano, com um maior cultivo de gêneros de primeira necessidade, e produção de excedentes, nas regiões próximas ao litoral, conforme se pode observar no quadro 8.

Quadro 8 - Mapa comparativo de produção, consumo e exportação das vilas da capitania do Rio Grande do Norte.

\begin{tabular}{|c|c|c|c|c|c|}
\hline & & Farinha & Feijão & Milho & Arroz \\
\hline \multirow{3}{*}{$\begin{array}{c}\text { Vila de Arez } \\
1810\end{array}$} & $\mathrm{P}$ & 1.105 & 4 & 18 & 46 \\
\hline & $\mathrm{C}$ & 1.012 & 4 & 18 & 46 \\
\hline & $\mathrm{E}$ & 93 & - & - & - \\
\hline \multirow{3}{*}{$\begin{array}{c}\text { Vila de } \\
\text { Extremoz } \\
1811\end{array}$} & $\mathrm{P}$ & 7.500 & 150 & 380 & 300 \\
\hline & $\mathrm{C}$ & 6.500 & 88 & 210 & 160 \\
\hline & $\mathrm{E}$ & 1.000 & 62 & 170 & 140 \\
\hline \multirow{3}{*}{$\begin{array}{c}\text { Cidade do } \\
\text { Natal } \\
1810\end{array}$} & $\mathrm{P}$ & 6.010 & 410 & 320 & 413 \\
\hline & $\mathrm{C}$ & 6.010 & 300 & 210 & 213 \\
\hline & $\mathrm{E}$ & - & 110 & - & 200 \\
\hline \multirow{3}{*}{$\begin{array}{c}\text { Vila Flor } \\
1810\end{array}$} & $\mathrm{P}$ & 450 & 10 & 10 & 20 \\
\hline & $\mathrm{C}$ & 450 & 10 & 10 & 20 \\
\hline & $\mathrm{E}$ & - & - & - & - \\
\hline \multirow{3}{*}{$\begin{array}{c}\text { Vila da } \\
\text { Princesa } \\
1811\end{array}$} & $\mathrm{P}$ & 300 & 140 & 60 & 20 \\
\hline & $\mathrm{C}$ & 5.635 & 220 & 280 & 70 \\
\hline & $E$ & - & - & - & - \\
\hline \multirow{3}{*}{$\begin{array}{c}\text { Vila de } \\
\text { Portalegre } \\
1810\end{array}$} & $\mathrm{P}$ & 200 & 10 & - & 6 \\
\hline & $\mathrm{C}$ & 200 & 10 & - & 6 \\
\hline & $\mathrm{E}$ & - & - & - & - \\
\hline
\end{tabular}

FONTE: DIAS, Thiago Alves. Dinâmicas mercantis coloniais: Capitania do Rio Grande do Norte 1760-1821. Dissertação(Mestrado). UFRN, Natal, 2011, p. 224. Legenda: "P" indica produção; "C" indica consumo; e "E" indica exportação.

No quadro acima, elaborado por Thiago Alves Dias, é possível perceber que a Vila de Extremoz, Vila de Arez, e a Cidade de Natal, todas situadas na faixa litorânea da capitania, alcançaram as maiores produções de alimentos naquele ano, segundo os registros. Possuíram suficiente farinha para exportação as Vilas de Arez e Extremoz, com destaque para a última. Em informação de 1774, o governador da capitania Geral de Pernambuco, já reconhecia a 
capacidade produtiva da Vila Extremoz, apontando que à mesma pertenciam "duas legoas de terra muito superior onde plantão suas lavouras todo o anno sem necessidade de chuvas por terem bons alagadiços, os quaes ficão distantes da Villa três legoas"225.

As duas últimas vilas listadas no quadro 8, a Vila da Princesa, situada no Assú, e a Vila de Portalegre, nas ribeiras do Apodi, produziram quantitativos menores de gêneros de primeira necessidade em relação às demais. Apesar da baixa produção naquele ano, a Vila de Portalegre teria produzido o suficiente para o seu consumo. Já a Vila da Princesa, nas várzeas do Assú, grande espaço pecuarista, teve que importar quase que a totalidade da farinha necessária para o consumo da vila, bem como boa parte dos demais gêneros alimentícios listados necessários para o seu abastecimento.

Ainda a respeito do cultivo de alimentos no sertão da capitania do Rio Grande do Norte, o mapa elaborado pelo Padre Joaquim José Pereira sobre o cultivo de mandioca e o fabrico de farinha na Ribeira do Apodi, quadro 9, fornece dados bem específicos e esclarecedores. Pereira elaborou o mapa quando uma forte seca atingia a região, assim, através desses números de produção e de consumo é possível supor que o autor tinha em vista contabilizar os mantimentos que seriam necessários àquelas freguesias durante a intempérie. Ao justificar a elaboração do mapa, o autor apontou que:

ele faz ver a quantidade de suas plantagens, o número dos seus lavradores, o que pode comer aquele povo por ano, e cada indivíduo por dias, e quanto lhes poderia restar de mantimentos para os dias futuros do ano seguinte, havendo providência a sua economia nos tempos próximo, e os desfavoráveis, para serem socorridos eles, e menos sensíveis as calamidades o povo que compõem os termos ${ }^{226}$.

\section{Quadro 9 - Mapa geral do Sertão da Ribeira do Apodi em 1792}

\begin{tabular}{|c|c|c|c|c|c|c|c|}
\hline $\begin{array}{c}\text { Denominação } \\
\text { das } \\
\begin{array}{c}\text { Freguesias } \\
\text { Paroquiais }\end{array}\end{array}$ & $\begin{array}{c}\text { Número } \\
\text { das } \\
\text { Almas de } \\
\text { cada uma }\end{array}$ & $\begin{array}{c}\text { Serras de } \\
\text { Plantagens }\end{array}$ & $\begin{array}{c}\text { Brejos de } \\
\text { Plantagens }\end{array}$ & $\begin{array}{c}\text { Covas de } \\
\text { mandioca } \\
\text { que } \\
\text { plantam }\end{array}$ & $\begin{array}{c}\text { Alqueires } \\
\text { de farinha } \\
\text { que } \\
\text { recolhem }\end{array}$ & $\begin{array}{c}\text { Alqueires } \\
\text { de farinha } \\
\text { que } \\
\text { gastam } \\
\text { por ano }\end{array}$ & $\begin{array}{c}\text { Número } \\
\text { de } \\
\text { lavradores }\end{array}$ \\
\hline $\begin{array}{c}\text { Vargens do } \\
\text { Apodi }\end{array}$ & 3.170 & 3 & 4 & 44.000 & 1.320 & 19.020 & 11 \\
\hline
\end{tabular}

225 "Ideia da População da Capitania de Pernambuco e de suas anexas". Coleção Pernambuco (Códices) Documentos do Acervo de Manuscritos, 11, 03,006, BN.

${ }^{226}$ PEREIRA, Joaquim José (Padre). Memória sobre a extrema fome e triste situação em que se achava o sertão da Ribeira do Apody da Capitania do Rio Grande do Norte, da comarca da Parahiba de Pernambuco. Revista do IHGB, tomo 20, 1857, p. 178. 


\begin{tabular}{|c|c|c|c|c|c|c|c|}
\hline $\begin{array}{c}\text { Vila de } \\
\text { Portalegre }\end{array}$ & 1.183 & 1 & 0 & 400.000 & 12.000 & 7.098 & 100 \\
\hline $\begin{array}{c}\text { Pao dos } \\
\text { Ferros }\end{array}$ & 4.357 & 12 & 0 & 1.444 .000 & 43.320 & 26.142 & 361 \\
\hline
\end{tabular}

Fonte: PEREIRA, Joaquim José (Padre). Memória sobre a extrema fome e triste situação em que se achava o sertão da Ribeira do Apody da Capitania do Rio Grande do Norte, da comarca da Parahiba de Pernambuco. Revista do IHGB, tomo 20, 1857, p. 183.

Sobre o quadro 9, primeiramente, é importante apontar as referências de Pereira às "serras de plantagens" e aos "brejos de plantagens". A respeito desse atributo geográfico o autor do documento escreveu que no Apodi "as suas serranias andarão as mais altas pelo nível do sertão do Piauhy, e por isso nelas é que se acham terras de plantagens" ${ }^{227}$. Como já foi visto, as serras úmidas e os brejos eram um enclave de umidade no meio semiárido, assim, o comentário feito por Pereira e o fato dessas regiões se encontrarem especificadas no seu mapa, reiteram a importância das mesmas para a agricultura em território sertanejo.

Como se pode observar, Pao dos Ferros foi a freguesia que mais produziu farinha de mandioca com o montante de 43.320 alqueires de farinha, dos quais apenas $60 \%$ era necessário para consumo próprio, restando cerca de 17 mil alqueires para comercializar par fora. Já a Vila de Portalegre, "situada em uma famoza serra onde plantão"228 foi autossuficiente e também capaz de produzir excedentes para exportação. Por outro lado, apesar do elevado número de habitantes, e de contar com três "serras de plantagens" e quatro "brejos de plantagens" poucos se dedicaram às roças de mandioca nas Vargens do Apodi, que contava com apenas onze lavradores. Diante disso, foram produzidos apenas 1.320 alqueires de farinha, insuficientes para o próprio consumo da freguesia, que tinha que importar grande parte da farinha necessária. Conforme já foi visto, a Ribeira do Apodi se configurou como um grande espaço pecuarista, onde, apenas 5\% das solicitações de terra tinham como objetivo único o estabelecimento de lavouras. Assim, a agricultura voltada para o abastecimento teria se desenvolvido entre os currais, e em locais menos adequados para a atividade pastoril, o que aliado às limitações impostas pelo clima e geografia da região, restringia bastante as áreas usadas para as lavouras de gêneros de primeira necessidade.

Conforme já foi visto, a capitania do Ceará teve como principal vetor econômico de ocupação do seu território a criação de gado, e apenas $9 \%$ do total de terras solicitadas tinham como justificativa para o seu uso o desenvolvimento de lavouras. Apesar da predominância da

\footnotetext{
${ }^{227}$ PEREIRA, Joaquim José (Padre). Memória, op. cit, p. 181.

228 "Ideia da População da Capitania de Pernambuco e de suas anexas". Coleção Pernambuco (Códices) Documentos do Acervo de Manuscritos, 11, 03,006, BN.
} 
atividade pecuária, a agricultura de gêneros de primeira necessidade se desenvolveu para atender as necessidades dos currais e dos centros urbanos em expansão ao longo do século XVIII. Sobre as áreas de cultivo de gêneros alimentícios na capitania, os principais dados são fornecidos pelo relatório do Governador José César de Menezes de 1774 e pela “descripção geográfica" elaborada por Antônio José Paulet em princípios dos oitocentos.

Na faixa litorânea da capitania, nas vilas de índios de Messejana, Arronches e Soure, a lavoura e a criação de gado era de onde provinha o sustento dos habitantes. Em seus territórios estavam incluídas serras destinadas a lavoura, onde plantavam gêneros como mandioca, milho, arroz, feijão e algodão, para o seu próprio consumo e para o abastecimento da Vila de Fortaleza. $\mathrm{Na}$ também vila litorânea de Aquiraz, a agricultura era a principal atividade desenvolvida, possuía engenhocas para o fabrico de rapaduras, e o cultivo de "mandioca, milho e algum feijão, que se consome na vila da Fortaleza e na do Aracati”. A respeito da vila de Fortaleza, apesar de ser abastecida pelas vilas circunvizinhas, em seus termos existia uma serra de plantações chamada Maranguape, onde legumes e até mesmo algodão eram cultivados.

Nas porções sertanejas da capitania, a produção de gêneros de primeira necessidade aconteceu de forma bastante semelhante às demais regiões semiáridas da Capitania Geral de Pernambuco. Reiterando o caráter pecuarista do sertão cearense, Paulet apontou as dificuldades do cultivo lavouras nas proximidades das fazendas "não só porque seriam necessárias grandes cercas para defender dos gados, mas também porque a aridez do terreno mal admite, a exepção das serra, que já indiquei, e de alguns lugares pantanozos"229. Assim, as dificuldades encontradas pelas lavouras de alimentos na região eram consequência do próprio funcionamento da atividade produtiva principal, a criação de gado e o seu problema de convivência com as plantações, bem como eram fruto das características climáticas e naturais do sertão do Ceará. O cultivo da mandioca, por exemplo, apesar famoso por não necessitar de solos muito férteis e por ter se difundido pela sua fácil adaptação e resistência à seca, se realizado em solos muito duros e secos, tornava a retirada das extensas raízes do tubérculo da terra uma atividade praticamente impossível. Assim, em território sertanejo, restava para o seu cultivo as ribeiras dos rios, que por consistirem em reservas de água mais estáveis eram predominantemente dedicadas a criação extensiva de gado, e as serras e brejos, onde de fato as roças de mandioca e demais lavouras de alimentos encontraram mais espaço para o seu desenvolvimento.

${ }^{229}$ PAULET, Antônio José da Silva. Descripção Geográfica Abreviada da Capitania do Ceará. RIHGB, v.96, pt. 2, 1897. Rio de Janeiro: IHGB, 1897, p.7. 
No extremo oeste da capitania do Ceará, a Vila do Crato foi descrita como um verdadeiro "oásis" no sertão, situada nas fraldas da Serra Grande, "ahi denominada Araripe". Segundo Paulet, nos anos mais secos sua produção seria de muito socorro "aos outros povos", entretanto, por plantarem apenas o necessário para os habitantes do seu termo a mesma não conseguia produzir grandes excedentes. Situada ao sul da Freguesia de Inhamuns e ao Oeste de Icó, a Freguesia de São José dos Careris também constituiu-se como um enclave de produção de alimentos no sertão do Ceará. Referenciada como fértil e amena pelo governador José César de Menezes, produzia "farinhas, frutas e rapaduras não só a todas as freguesias das suas vizinhanças, mas também de outros certoens mais remotos vem combois grandes a prover-se desses gêneros" ${ }^{" 230}$. Essas informações permitem vislumbrar que no sertão determinadas regiões funcionaram como enclaves de produção de alimentos, para o autoconsumo, o abastecimento de regiões circunvizinhas que não possuíam as qualidades físicas e climáticas necessárias para o desenvolvimento agrícola, bem como para atender as demandas daqueles que desciam dos sertões seguindo os passos das boiadas rumo às feiras nas proximidades do litoral.

As informações sobre a produção de alimentos são mais completas para a porção norte do sertão da capitania do Ceará, no que diz respeito a Ribeira do Acaraú, mais especificamente a Vila de Sobral e seus termos. A Ribeira do Acaraú era a segunda maior ribeira da capitania, e tinha como principal atividade produtiva a criação de gado, incrementada pela sua proximidade com a capitania vizinha do Piauhí ${ }^{231}$. Mesmo com a relevância da criação de gados na ribeira, outros gêneros eram necessários para o aprovisionamento das suas populações em crescimento, e a forma de consegui-los foi a partir do cultivo das serras, já que os terrenos das proximidades do rio Acaraú eram menos propícios ao cultivo de lavouras e sofriam periodicamente com as secas. A vila de Sobral, por exemplo, se encontrava localizada nas proximidades da serra da Meruoca e da Ibiapaba, de onde provinham os seus alimentos, bem como o abastecimento das vilas e freguesias circunvizinhas. A este respeito, o Padre Fortunato Alves Linhares, que foi Cura da freguesia na década de 1740, enfatizou a importância das serras para o desenvolvimento de Sobral, apontando que das "serras situadas à leste se dirigiam à fértil região da Ibiapaba, tinha ainda a seu favor a proximidade da serra de Meruoca, de clima ameno e doce, que a abastecia fartamente de cereais" ${ }^{\prime 232}$.

\footnotetext{
230 "Ideia da População da Capitania de Pernambuco e de suas anexas". Coleção Pernambuco (Códices) Documentos do Acervo de Manuscritos, 11, 03,006, BN.

${ }^{231}$ ROLIM, Leonardo Cândido. "Tempo das Carnes" no Siará Grande: dinâmica social, produção e comércio de carnes secas na Vila de Santa Cruz do Aracati (c. 1690 -c. 1802). Dissertação (Mestrado). UFPB, João Pessoa, 2012, p. 42.

${ }^{232}$ LINHARES, Padre Fortunato Alves. Notas Históricas da cidade de Sobral. Revista do Instituto Histórico do Ceará, Fortaleza, tomo XXXVI, 1922, p. 256-257.
} 
As propriedades de terras da vila de Sobral se dividiam entre fazendas de criar e sítios de plantar lavouras, assentadas na ribeira do Acaraú e nas serras, respectivamente ${ }^{233}$. Nas terras de serras, utilizadas unicamente para as lavouras, a criação de gado era, inclusive, proibida em virtude da inexistência de cercas ${ }^{234}$. Boa parte dos proprietários de sítios nas serras também possuía fazendas de gado na ribeira do Acaraú, cerca de 60\%, mas pagavam trabalhadores livres ou permitiam o assentamento de moradores em seus sítios para cuidar das lavouras ${ }^{235}$. Nos sítios era cultivada, principalmente, a mandioca, seguida do milho, do feijão e do arroz, que serviam ao abastecimento dos currais que se localizavam nas terras baixas, e improprias para o plantio, e cujos excedentes podiam ser comercializados entre fazendas, povoações e vilas, com a de Granja, que se encontrava nas proximidades.

No mapa a seguir (Mapa 2), é possível observar a localização das Freguesias e Vilas aqui mencionadas, identificadas na documentação trabalhada, que produziam excedentes de alimentos, e que abasteciam regiões que não possuíam uma produção suficiente. Observando o mapa, percebe-se que cerca de $60 \%$ das regiões produtoras de alimentos identificadas se encontravam aglomeradas nas proximidades da faixa litorânea. No sertão, as zonas produtoras eram mais esparsas, encontradas em número menor.

${ }^{233}$ OLIVEIRA, Adriana Santos de. Pecuária, Agricultura e Comércio: Dinâmica das Relações Econômicas no Termo da Vila de Sobral. Dissertação ( Mestrado). UFC, Fortaleza, 2015, p. 66

${ }^{234}$ PINHEIRO, Francisco José. Notas sobre a formação social do Ceará, 1680-1820. Fortaleza: Fundação Ana Lima, 2008. p. 23.

${ }^{235}$ OLIVEIRA, Adriana Santos de. Pecuária, Agricultura e Comércio... Op. cit, p. 68. 
Mapa 2 - Vilas e Freguesias que produziam excedentes de alimentos na Capitania Geral de Pernambuco na segunda metade do século XVIII.

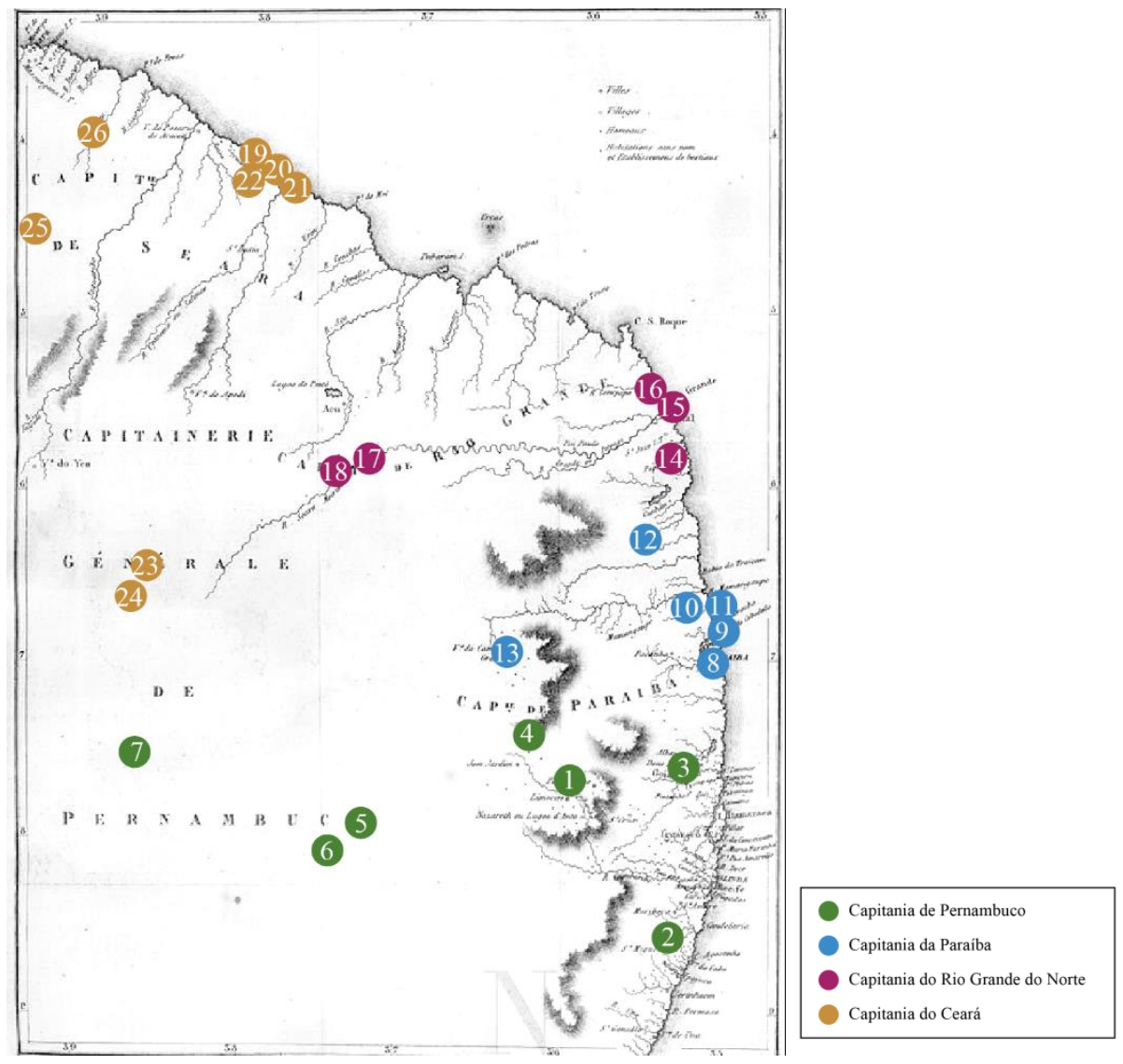

Legenda: 1- Paudalho, 2 - Santo Amaro do Jaboatão, 3- Goiana, 4 Cimbres, 5 - Garanhuns, 6- Águas Belas, 7 Cabrobó, 8 - Cidade da Paraíba, 9 - Alhandra, 10 - São Miguel, 11- Conde, 12- Bananeiras, 13 - Vila Nova da Rainha, 14 - Arez, 15 - Natal, 16 - Extremoz, 17 - Portalegre, 18 - Pau dos Ferros, 19 - Arronches, 20 Messejana, 21 - Aquiraz, 22 - Serra de Maranguape, 23 - São José dos Careris, 24 - Crato, 25 - Serra da Ibiapaba, 26 - Serra da Meruoca.

Diante do quadro aqui exposto, percebe-se que o cultivo de gêneros alimentícios em toda a extensão das capitanias de Pernambuco e anexas esteve condicionado a duas questões: a principal atividade produtiva desenvolvida e as características naturais inerentes a determinadas áreas. De forma geral, o número de vilas e freguesias que se dedicavam a produção de alimentos e produziam maiores excedentes era maior na proximidade da faixa litorânea, mesmo que ocupassem terras preteridas pelo açúcar, e menos férteis em relação aos solos de massapê. Nessas áreas, as lavouras dos gêneros de primeira necessidade eram cultivadas principalmente por vilas de indígenas e agricultores livres, que produziam o suficiente para o seu autoconsumo e vendiam os excedentes para o abastecimento de outras regiões. Já nas áreas mais afastadas do litoral, o cultivo de alimentos teve que lidar com empecilhos geográficos que restringiram as possibilidades de cultivo a extensões mais limitadas. As serras e os brejos configuraram-se, nesse sentido, como as principais áreas de produção de alimentos no semiárido, responsáveis 
pelo abastecimento de vilas e freguesias que se dedicavam principalmente a atividade pastoril, mas que não possuíam os atributos necessários para o desenvolvimento de produção agrícola suficiente para o seu próprio abastecimento. Somando-se a produção de alimentos insuficientes de grandes vilas sertanejas com a ocorrência de frequentes episódios de secas na região, é possível supor que a produção de alimentos no sertão era instável, e não produzia excedentes suficientes para conseguir lidar de forma autônoma com problemas de longo prazo.

\section{Vigilância, regulamentação e problemas de abastecimento}

Predominantemente agrícolas, as sociedades de Antigo Regime sofreram com a escassez de cereais em graus diversos. As medidas governamentais voltadas para o abastecimento das populações muitas vezes apresentaram um alcance limitado frente a utilização de técnicas rudimentares de cultivo e as oscilações de colheitas. Não obstante as irregularidades da produção, manter os baixos preços dos gêneros da primeira necessidade era considerado um dever do soberano e dos seus representantes, que deveriam atuar no sentindo de garantir o aprovisionamento barato dos aglomerados urbanos a fim de evitar possíveis desordens causadas pela carestia e fome ${ }^{236}$.

Thompson em seu ensaio "A economia moral da multidão inglesa no século XVIII", afirmou que na Inglaterra dos séculos XVI e XVII, a intervenção de autoridades no comércio dos gêneros de primeira necessidade era costumeira. Uma vez que se acreditava que as carestias eram ocasionadas por agricultores e monopolistas ambiciosos que agiam de forma a desrespeitar as regras estabelecidas para o bom funcionamento do mercado, o que legitimava a intervenção das autoridades no sentido de garantir aos mais pobres o abastecimento de alimentos a preços justos ${ }^{237}$.

Já em meados dos setecentos, as ideias do liberalismo começaram a determinar mudanças drásticas na organização do mercado de alimentos inglês. Esse novo modelo de economia foi apresentado por Adam Smith, na sua obra "A riqueza das nações”. Com relação ao comércio de cereais, Smith apontou que o maior inimigo do livre mercado era a interferência do estado, que ao colocar obstáculos ao livre fluxo de gêneros das regiões de maior abundância para as regiões de escassez, seria o grande responsável pelas carestias ${ }^{238}$. Segundo o autor, na ausência de limites à livre circulação, as relações entre oferta e procura manteriam os preços

\footnotetext{
${ }^{236}$ SILBERT, Albert. Do Portugal de antigo regime ao Portugal oitocentista. Lisboa: Horizontes, 1977 , p. 16.

237 THOMPSON, E. P. Constumes em comum: estudos sobre a cultura popular tradicional. São Paulo: Companhia das Letras, 1998. P. $150-202$.

${ }^{238}$ SMITH, Adam. Uma investigação sobre a natureza e causas da riqueza das nações. Rio de Janeiro, Ediouro, 1986, p. $47-48$.
} 
dos gêneros de primeira necessidade próximos ao natural, que seriam regulados “pela proporção entre a quantidade que é realmente trazida ao mercado, e a demanda daqueles que desejam pagar o preço natural da mercadoria, ou todo o valor da renda, trabalho e lucro, que deve ser pago de modo a poder trazê-la" ${ }^{239}$. Assim, segundo essa "demanda efetiva", os indivíduos pagariam o valor que fosse necessário para levar esses gêneros ao mercado, e se a oferta de um determinado vívere fosse insuficiente para garantir essa demanda, algumas pessoas estariam dispostas a pagar mais por ela. Da mesma forma, se a quantidade ofertada fosse superior à demanda efetiva, os preços da mercadoria seriam reduzidos. Assim o preço dos gêneros "cairá mais ou menos abaixo do preço natural, conforme magnitude do excesso aumente mais ou menos a competição dos vendedores, ou conforme seja mais ou menos importante para eles disporem imediatamente a mercadoria" 240 .

Ao desacreditar da intervenção das autoridades do Estado sobre o mercado, essa teoria, entretanto, não considerava as necessidades urgentes das camadas mais pobres, que não conseguiriam esperar o aumento da oferta para obter os gêneros essenciais a sua conservação. Diante disso, segundo Thompson, na Inglaterra essas mudanças teriam levado a ocorrência de diversas revoltas populares, com invasões de padarias, bloqueio de estradas para evitar a saída de cereais, e indivíduos revoltados afixando avisos e anúncios com o intuito de chamar o povo a participar de manifestações. Esses atos eram uma evidente demonstração de repúdio a indiferença das autoridades diante de um problema que, tradicionalmente, era de sua responsabilidade. Os revoltosos viam as ações de atravessadores e açambarcadores de grãos, bem como as tentativas de se liberalizar o comércio, como uma afronta ao modelo paternalista de regulamentação do comércio desses gêneros, que descumpriam os preceitos da economia moral, que estabelecia formas de regulamentação que garantiam a equidade das trocas ${ }^{241}$.

Para o caso português, segundo Flávio Marcus da Silva, apesar das ideias liberais que circulavam na Europa terem se assentado no governo durante o reformismo ilustrado português, as reformas de Pombal não causaram grandes mudanças no que diz respeito às políticas ligadas ao abastecimento interno ${ }^{242}$. E ao longo de todo o setecentos, para garantir o aprovisionamento das populações em expansão, doutrinas e práticas econômicas dominadas pelo protecionismo e

\footnotetext{
${ }^{239}$ SMITH, Adam. Uma investigação sobre a natureza e causas da riqueza das naçõesI. op. cit, p. 47 - 48.

${ }^{240}$ Idem .

241 THOMPSON, E. P. Constumes em comum... op, cit, p. 192

242 SILVA, Flávio Marcus da. Subsistência e Poder: A política de abastecimento alimentas nas Minas setecentistas. Belo Horizonte: Editora UFMG, 2008, p. 37.
} 
pelo intervencionismo do Estado e das autoridades municipais foram adotadas nos domínios do ultramar $^{243}$.

O conceito de "economia moral" da forma como foi formulado por Thompson, se baseia na ideia da existência de um consenso popular que se legitima através das tradições antigas de intervenção das autoridades no mercado de gêneros de primeira necessidade, que entraria em conflito com uma nova economia política pautada no livre mercado. Entretanto, em seu ensaio "A economia moral revisitada", o próprio Thompson percebeu o uso do conceito para diversos contextos e épocas em trabalhos sobre a África, Ásia e América do Sul, que o compreendiam como uma "dialética social da mutualidade desigual (necessidade e obrigação)". Diante disso, numa definição mais ampla, economia moral poderia se referir

ao modo como as relações de classe são negociadas. Ela mostra como a hegemonia não é apenas imposta (ou contestada), mas também é articulada nas relações diárias de uma comunidade, sendo mantida apenas por concessão e proteção (nos tempos bons) e, pelo menos, por gestos de amparo nos tempos difíceis ${ }^{244}$.

Dessa forma, o conceito poderia ser empregado mesmo para realidades e períodos históricos em que não existisse uma tensão entre a concepção de normas e obrigações sociais tradicionais e uma nova postura econômica. A economia moral como uma negociação em que se estabelecia uma relação de obrigações mútuas entre as autoridades e as camadas populares pode, então, ser percebida na postura das autoridades coloniais em relação a produção e a comercialização de gêneros de primeira necessidade na América portuguesa.

O governo da Capitania Geral de Pernambuco e as câmaras das suas Vilas se apoiaram em práticas que visavam garantir um escoamento estável de alimentos por um "preço justo" para a população em troca da manutenção do sossego e da ordem social. A produção de gêneros alimentícios visava, além de garantir suficientes suprimentos para a população urbana em expansão, atender as exigências particulares da estrutura econômica agroexportadora. Diante disso, buscou-se então regulamentar a produção e o comércio de gêneros de primeira necessidade como forma de solucionar problemas ligados ao abastecimento, e em tempos de escassez, rotinas de emergência eram adotadas segundo um modelo "paternalista do mercado de alimentos" ${ }^{245}$. O rigor da fiscalização variava na proporção inversa do volume da colheita ${ }^{246}$,

\footnotetext{
${ }^{243}$ LINHARES, Maria Yedda. A pecuária e a produção de alimentos no período colonial. In. Tamás Szmrecsanyi. (org.). História econômica do período colonial. São Paulo: Huicitec. 2002. p.111.

244 THOMPSON, E. P. Constumes em comum...Op. cit, p. 260-161.

${ }^{245}$ Ibidem, p. 204.

${ }^{246}$ SILBERT, Albert. Do Portugal de antigo regime ao Portugal oitocentista. Lisboa: Horizontes, 1977, p. 11-13
} 
sempre no intuito de garantir uma oferta de gêneros que fosse correspondente às demandas dos povos.

Tanto em Portugal quanto em suas conquistas, seguindo um direito costumeiro, e devidamente expresso nas Ordenações do Reino, a organização e o provimento núcleos urbanos se encontravam sob a responsabilidade das Câmaras ${ }^{247}$, que acumulavam funções fiscalizadoras, reguladoras, e punitivas. No âmbito local, a municipalidade atuava em conjunto com o governador da capitania, no intuito de proteger e fazer avançar o cultivo de víveres voltados para o abastecimento ${ }^{248}$, como forma de manter o bom funcionamento do complexo agroexportador e a ordem pública.

A produção a e comercialização de gêneros alimentícios foram preocupações constantes das autoridades de Pernambuco e capitanias anexas. Conforme já foi dito anteriormente, apesar de amplamente consumidos, o milho, o feijão e o arroz, ocupavam uma posição secundaria diante do consumo da farinha de mandioca na alimentação cotidiana, que se configurou como gênero alimentício básico na dieta da população. A presença frequente deste gênero em alvarás, ordens, editais, bandos e cartas trocadas entre as autoridades da capitania Geral de Pernambuco demonstram a centralidade do papel que farinha de mandioca teve na subsistência durante o período colonial.

Em uma troca de cartas entre o governador da capitania Geral de Pernambuco, D. Tomás José de Mello, e a Rainha D. Maria em 1797, José de Mello, elencava as principais medidas tomadas ao longo dos setecentos com relação ao fomento do plantio da mandioca na capitania. Nesse conjunto documental, é possível perceber o constante empenho do governador e de seus antecessores para que o cultivo do gênero fosse ampliado e atendesse as necessidades de Pernambuco e anexas. Nos próximos parágrafos, as informações fornecidas pelo governador foram cruzadas com as abarcadas em outros documentos, com o intuito de se desenvolver uma análise mais completa sobre essas determinações e as suas repercussões.

Segundo D. Tomás, não obstante um Alvará de 1688 que obrigava "a todos os moradores indistintamente a plantar 500 covas de mandioca para cada escravo que tivessem de serviço", a "decadência e esquecimento" do cultivo da mandioca levou à ampliação destas determinações por meio de outro Alvará, publicado em 27 de fevereiro de 1701. Apesar de discutido amplamente na historiografia por ter "expulsado" o gado para o sertão, o Alvará de

\footnotetext{
${ }^{247}$ MATTOSO, José. (org.). História de Portugal: o Antigo Regime. Lisboa: Estampa, 1993, p. 270.

${ }^{248}$ SOUSA, Avanete, Pereira. Poder local e vida cotidiana no Brasil colonial: o papel da Câmara Municipal na organização social da cidade de Salvador no século XVIII e início do XIX. Dissertação de mestrado. Salvador: UFBA/ FFCH/PPGH, 1996, p. 39-40
} 
1701 também foi relevante ao tratar das lavouras de subsistência. Por meio dele se estipulava que senhores de engenho e lavradores de cana ou tabaco, que possuíssem "terras capazes", fossem obrigados a plantar covas de mandioca suficientes para que "pudessem comodamente sustentar com a terça parte do rendimento delas a sua família e fábrica e destinassem as duas partes para vender ao Povo". Ademais, também ficava proibido que "plantassem canas pessoas que não possuíssem de seis escravos para cima" ${ }^{249}$. Para o cumprimento dessas medidas, solicitava-se que "Capitães Mores dos Distritos conferissem esta matéria com os Ouvidores Gerais e Oficiais das Câmaras para que inviolavelmente toda pessoa de qualquer qualidade e condição que fosse, se não escusasse de plantar na forma referida" ${ }^{250}$. A intenção dessas determinações era, sobretudo, manter o equilíbrio entre a produção de alimentos e as demandas do mercado interno, não só evitando que a grande lavoura concorresse pelos gêneros alimentícios dos centros urbanos, como também produzisse excedentes.

No entanto, as determinações do sobredito Alvará não teriam sido bem recebidas pelos produtores que tinham poucos escravos e se dedicavam à cultura de gêneros voltados para a exportação, geradores de maiores lucros, que não desejavam dedicar-se as lavouras de gêneros de primeira necessidade. A respeito da imposição que lavradores com menos de seis escravos não podiam se dedicar a culturas de exportação, em 1704, o Senado da Câmara do Recife escrevia ao rei, alegando que, diferentemente do que era visto na Bahia, naquela terra era “menor o número dos escravos, de sorte que não são muitos os lavradores de canas que tem de seis escravos para cima", e que o dito Alvará causava "grande prejuízo a estes moradores e diminuição da fazenda real". Diante disso, solicitavam que esta proibição fosse feita apenas para os lavradores que possuíssem menos de três escravos, "pois assim haverá abundância de farinha (...) e não faltarão o açúcar, de cuja cultura já vem deixando os senhores de engenhos cujos partidos se lavram com menos escravos do que a Lei requer" ${ }^{251}$. Somando-se a representação da vereança do Recife com as de outras municipalidades, como a da Vila do Porto Calvo, o Alvará foi revogado pelas "supostas dificuldades que se representaram nas capitanias deste Governo, ficando no arbítrio de cada um plantar canas ou mandioca, sem atenção ao

\footnotetext{
${ }^{249}$ AHU - Avulsos de Pernambuco, D. 13603. Recife, 21 de agosto de 1797. Carta do governador da capitania de Pernambuco, Tomás José de Melo, à rainha, D. Maria, informando seu parecer sobre um edital expedido pela Câmara do Recife, referente a proibição da entrada de carga de algodão sem levar também a farinha de mandioca. ${ }^{250}$ AHU - Avulsos de Pernambuco, D. 13603. Recife, 21 de agosto de 1797. Carta do governador da capitania de Pernambuco, Tomás José de Melo, à rainha, D. Maria, informando seu parecer sobre um edital expedido pela Câmara do Recife, referente a proibição da entrada de carga de algodão sem levar também a farinha de mandioca. ${ }^{251}$ AHU - Avulsos de Pernambuco, D. 1967 Recife, 09 de abril de 1704. Carta dos oficiais da câmara do Recife ao Rei, D. Pedro II sobre a proibição aos lavradores com menos de seis escravos, e pedindo para que o cultivo da farinha de mandioca fosse realizado pelos lavradores com menos de três escravos.
} 
número de escravos que tivesse" 252 . O rigor do estímulo da produção de gêneros alimentícios podia variar de acordo com a colheita, e diante desse afrouxamento nas determinações relativas ao plantio de mandioca, é provável que naquele momento o cultivo de mandioca fosse abundante e suficiente para atender as demandas da capitania.

Em longo prazo, entretanto, a revogação do Alvará não parecer ter contribuído para o incremento do cultivo de mandioca, e, diante da liberdade de escolha que tinham, os lavradores continuavam optando por dedicar a maior parte das terras aos gêneros mais lucrativos de exportação. Em 1763, num momento em que a oferta de farinha de mandioca já não conseguia atender as demandas da população, a Câmara do Recife solicitava ao Rei que eles pudessem fazer valer o Alvará que versava sobre o lavrador ter "que plantar o número de covas de mandiocas não só do sustento das famílias, mas ainda do bem público pelo excesso que resulta pela falta da dita planta", impondo duras penas aos que não o cumprissem o solicitado ${ }^{253}$. Já em 1777, segundo o governador D. Tomás José de Mello, o seu antecessor, José César de Menezes, ao observar que começava a "subir o preço da farinha e a experimentar-se a falta dela", encarregou os ouvidores das comarcas e as câmaras a "proverem remédio sobre este artigo". Menezes determinou, então, "fazer assinar termo aos agricultores de todas as lavouras para plantarem por cada cabeça de escravos mil covas de mandioca ${ }^{254}$ ". Apenas dois anos depois, César de Menezes queixava-se novamente da carestia dos gêneros de primeira necessidade, "principalmente a farinha de mandioca, que é o pão comum", por "terem os Lavradores se aplicado mais na lavoura do açúcar por julgarem mais nobre exercício" 255.

Para senhores de engenho e lavradores de canas e outras culturas, usar os próprios escravos para cultivar lavouras de subsistência não consistia apenas em uma estratégia possível de abastecimento; era uma obrigação legal. Entretanto, a repetição dessas determinações pelas autoridades é sugestiva por si, uma vez que se tivessem sido obedecidas, não seria necessário reeditá-las a cada ameaça de escassez de farinha.

\footnotetext{
${ }^{252}$ AHU - Avulsos de Pernambuco, D. 13603. Recife, 21 de agosto de 1797. Carta do governador da capitania de Pernambuco, Tomás José de Melo, à rainha, D. Maria, informando seu parecer sobre um edital expedido pela Câmara do Recife, referente a proibição da entrada de carga de algodão sem levar também a farinha de mandioca. ${ }^{253}$ AHU - Avulsos de Pernambuco, D. 7793. Recife, 23 de julho de 1763. Carta dos oficiais da câmara do Recife ao rei D. José, sobre a falta de plantações de mandiocas para o sustento das famílias devido aos estragos feitos pelos gados, e a imposição de novas penas para os lavradores que não plantarem lavouras suficiente para o bem comum e sustento de suas famílias.

${ }^{254}$ AHU - Avulsos de Pernambuco, D. 13603. Recife, 21 de agosto de 1797. Carta do governador da capitania de Pernambuco, Tomás José de Melo, à rainha, D. Maria, informando seu parecer sobre um edital expedido pela Câmara do Recife, referente a proibição da entrada de carga de algodão sem levar também a farinha de mandioca. ${ }^{255}$ AHU - Avulsos de Pernambuco, D. 10183. Recife, 3 de junho de 1780. Ofício do governador da capitania de Pernambuco, José César de Meneses, ao secretário de estado da Marinha e Ultramar, Martinho de Melo e Castro, sobre a subida do preço da mandioca, em razão da preferência dos agricultores pela lavou de cana do açúcar.
} 
Em carta de janeiro de 1781 encaminhada ao Governo de Pernambuco, o Senado da Câmara de Igarassu, relatava a grande falta da farinha "que estamos experimentando pelo preço que já logram 800 réis" ${ }^{256}$. Segundo os camaristas, os preços altos se davam graças ao fato de que boa parte dos que se dedicavam às roças de mandioca "voltaram a lavradores de canas com a ambição do preço que está logrando o açúcar, ainda aqueles que não têm a necessária fábrica". Diante dessa situação, o Senado da Câmara mandou fixar editais nos termos da Vila de Igarassu lembrando aos moradores a atenção que deveriam ter com "a plantação das roças tão necessárias ao nosso país" ${ }^{257}$, e solicitavam ao Governador apoio em relação à postura adotada.

Diante da situação exposta pelos homens da Câmara de Igarassu, compartilhando das mesmas preocupações, José César de Menezes, então Governador, decidiu estender as medidas tomadas pelos camaristas paras as capitanias e Câmaras que se encontravam sob a sua jurisdição. Foram encaminhadas, então, cartas às Câmaras das vilas de Olinda, Goyana, Recife, Paraíba, Natal, de Fortaleza, Aquiraz, Aracati, Icó, Sobral e Granja. Nelas o Governador recriminava o "indolente descuido que até agora tem havido tanto da parte das Câmaras, como dos Corregedores das Comarcas, em um artigo de tanta importância”. Assim, com o objetivo de "evitar os progressos deste dano, e as perniciosas consequências que ele ameaça", reiterava a determinação que proibia "todo lavrador que não tiver para cima de seis escravos poder empregar-se em outra cultura que não seja a de roças de mandioca", solicitando, por fim, que os Camaristas dedicassem "vigilante cuidado no cumprimento desta ordem"258.

Diante da correspondência trocada entre Governo e autoridades camarárias, percebe-se o esforço conjunto das diversas esferas do poder local para garantir uma produção regular de alimentos a preços justos. Nota-se também que o problema da agricultura de alimentos não estava apenas na recusa da grande lavoura em produzir o alimento necessário para sua subsistência, e excedentes para o mercado, mas no próprio desinteresse daqueles que se dedicavam exclusivamente a produção de alimentos. Uma vez que em momentos de elevação nos preços dos gêneros de exportação, almejando auferir maiores lucros, roceiros de mandioca e demais legumes deixavam esses gêneros de lado e passavam a se dedicar com mais afinco aos produtos mais demandados pelo mercado europeu.

\footnotetext{
${ }^{256}$ APEJE - Ofício do Governo (3), Fls. 150v - 155. 19 de Janeiro de 1782. Carta circular que se escreveu às Câmaras abaixo declaradas sobre a cultura das roças de mandioca.

${ }^{257}$ APEJE - Ofício do Governo (3), Fls. 150v - 155. 19 de Janeiro de 1782. Carta circular que se escreveu às Câmaras abaixo declaradas sobre a cultura das roças de mandioca.

${ }^{258}$ APEJE - Ofício do Governo (3), Fls. 150v - 155. 19 de Janeiro de 1782. Carta circular que se escreveu às Câmaras abaixo declaradas sobre a cultura das roças de mandioca.
} 
Longe das plantations, a falta de interesse no cultivo de alimentos no sertão era também motivo de alerta para as autoridades coloniais. Conforme já foi visto anteriormente, nas regiões interioranas de Pernambuco e anexas, em parte graças às particularidades do seu clima, o desenvolvimento das lavouras de alimentos encontrou variadas limitações. Mesmo assim, a necessidade de escoamento de gêneros para áreas que não eram autossuficientes preocupava as autoridades coloniais. Em Oficio de 1782, escrito ao Secretário dos Negócios da Marinha e Ultramar, o Capitão-mor do Ceará, João Batista de Azevedo Coutinho, comunicava as necessidades de abastecimento pelas quais passava a capitania diante da "inercia dos seus habitantes que até a cultura do seu próprio pão e principal sustento era dele ou não conhecida, ou desprezada". De acordo com Coutinho, a população dedicava-se com mais afinco a criação de gado, deixando a agricultura de lado de tal forma que "a farinha de pão ou de mandioca (...) lhes vinha de Pernambuco e das outras capitanias do sul" ${ }^{259}$. No tocante a mesma questão, em carta escrita seis anos depois, o Governador Geral de Pernambuco, queixava-se ao Capitão-Mor do Ceará que como de costume "hum ou mais barcos" carregados de farinha "para esta praça o levaram aos povos dos ditos sertoens". O Governador, então, determinava ao Capitão-Mor que, juntamente com as Câmaras, encontrasse formas de persuadir o povo "para animar esse país a agricultura, e com especificidade o do alimento mais indispensável, qual he a mandioca", acrescentando com otimismo que "sendo [a produção] menor nos sertões podem estes se cultivados dar farinha para todas estas capitanias" 260 .

O desinteresse de uma boa parcela de agricultores no cumprimento das determinações sobre o cultivo gêneros de primeira necessidade exigiu, por vezes, um posicionamento fiscalizador mais enérgico e incisivo das autoridades coloniais. Em carta encontrada no Livro de Registro da Câmara do Recife, o Ouvidor Geral de Pernambuco, Antônio José Barroso, aconselhava ao Senado da Câmara que, a respeito do fomento da produção de alimentos, não “devem contentar-se somente com mandarem fixar Edictaes sobre a plantação das mandiocas". Segundo o Ouvidor, a municipalidade do Recife poderia agir de forma semelhante às demais Câmaras da Comarca e:

irem de correição pelo termo da Villa, e mandarem os Almotaceis aonde não poderem chegar, destinando-lhes para isso ventenarios, e fazerem termos, em que assignem os Senhores de Engenhos, e Lavradores para que os primeiros plantem tanta mandioca, que com a terça parte sustentem as suas fabricas, e a

\footnotetext{
${ }^{259}$ AHU - Ceará, D. 590. Ceará, s/d 1782. Ofício do capitão-mor do Ceará, João Batista de Azevedo Coutinho de Montauri, a Martinho de Melo e Castro, sobre as condições de abastecimento.

${ }^{260}$ AHU - Pernambuco, D. 11704. Recife, 23 de maio de 1788. Ofício do Governador da capitania de Pernambuco, D. Tomás José de Melo, ao secretário de estado da Marinha e Ultramar, Martinho de Melo e Castro, sobre as providências para produção e distribuição de carne fresca, carne salgada e farinha na dita capitania.
} 
mais venderem ao Povo, e os segundoz, que tiverem menos de seis escravos senão apliquem a outra planta ${ }^{261}$.

Além da assinatura de termos de comprometimento, outra ação recorrente em momentos de acentuada baixa na produção de alimentos foi a realização de mapeamentos e vistorias de roças de mandioca. Em 1790, o Governador Geral de Pernambuco escrevia aos Capitães-Mores de sua jurisdição para que determinassem que os Comandantes e Capitães das Freguesias "tirassem mapas de todas as roças que houvessem nos seus distritos" para que se tomasse conhecimento da quantidade de lavouras que havia, e "das pessoas que faltavam a obrigação de plantar as mil covas que se tinham sido determinadas" ${ }^{\text {"262 }}$. O Governador justificava que essa postura se fazia necessária visto que "senhores de engenhos e lavradores não só não plantavam mandioca que pudessem vender ao povo, mas que nem a plantavam bastante para a sua sustentação e das suas fábricas, antes a compravam em prejuízo daqueles que seguiam outro modo de vida" 263 .

Prática semelhante à do Governador Geral de Pernambuco já havia sido empreendida pelo Senado da Câmara da Vila de Natal em finais de seiscentos. Os Camarários, diante da "necessidade que padece o povo pela falta grande que há de farinha", determinava que o Almotacé "fosse fazer vistoria nas roças dos lavradores que plantavam mandiocas para que ache algumas capazes de se poder valer dela para remediar a grande necessidade" 264 . Ao adotar essa postura, a municipalidade de Natal intentava não só tomar conhecimento das roças que se encontravam produtivas naquele momento de carestia, como também garantir o escoamento imediato dos gêneros necessários ao aprovisionamento da Vila, fiscalizando a sua saída direto do produtor e evitando, assim, a ação de intermediários que podiam almejar maiores lucros.

Para que essas fiscalizações fossem realizadas de forma efetiva, as Câmaras contavam com agentes específicos que se deslocavam pelos termos da sua jurisdição fazendo valer as deliberações da municipalidade. Esses agentes eram os Almotacés, que desenvolviam um papel essencial na garantia do aprovisionamento das Vilas. Entre as suas principais atribuições estava

\footnotetext{
${ }^{261}$ IAHGP - LRCMR (1733-1808), Fls. 56 - 57v. Recife, 04 de janeiro de 1785. Registro de uma Carta do Doutor Desenbargador Ouvidor Geral, e Corregedor da Comarca José Pereira Barrozo de Miranda Leite.

${ }^{262}$ AHU - Avulsos de Pernambuco, D. 13603. Recife, 21 de agosto de 1797. Carta do governador da capitania de Pernambuco, Tomás José de Melo, à rainha, D. Maria, informando seu parecer sobre um edital expedido pela Câmara do Recife, referente a proibição da entrada de carga de algodão sem levar também a farinha de mandioca. ${ }^{263}$ AHU - Avulsos de Pernambuco, D. 13603. Recife, 21 de agosto de 1797. Carta do governador da capitania de Pernambuco, Tomás José de Melo, à rainha, D. Maria, informando seu parecer sobre um edital expedido pela Câmara do Recife, referente a proibição da entrada de carga de algodão sem levar também a farinha de mandioca. ${ }^{264}$ IHGRN - LTVSCN (1674 - 1698), Fl. 108v.Termo de Vereação de 01 de setembro 1697.
} 
a de "fiscalizar o abastecimento de víveres paras a localidade" ${ }^{265}$, garantindo a qualidade da produção, tabelando preços, evitando monopólios e intermediações que encarecessem os gêneros $^{266}$. Cargo instituído na América portuguesa em 1532, segundo Magnus Pereira, o Almotacé deveria conduzir suas ações de acordo com a "noção de que o mercado deveria ser pautado por uma moralidade, na busca do preço justo"267. Este cargo esteve presente em todas as vilas das capitanias de Pernambuco e Anexas.

A fiscalização e a obrigatoriedade do cultivo de alimentos eram tentativas de promover um aumento na produção dos gêneros, entretanto, essas práticas, por si sós, não eram suficientes para garantir que esses víveres essenciais fossem chegar às mesas das populações das vilas a preços acessíveis. Assim, para garantir o aprovisionamento estável e regular das vilas, principalmente em momentos de escassez, as autoridades coloniais também olhavam com atenção para o escoamento dos gêneros que saiam das roças e o seu comércio, na lógica de que a culpa da escassez também poderia ser causada pela ação de açambarcadores e monopolistas.

Uma das formas encontradas pelas autoridades para salvaguardar a oferta de alimentos nas vilas foi através da vigilância portuária, que tinha no Almotacé sua principal sentinela. Sobre esta prática, em ata de 1693, diante da escassez de farinha que se experimentava, o Senado da Câmara de Natal acordava que "nenhuma pessoa que lavra farinha a mandem para fora do termo. Como também os mestres dos barcos a não possam levar sem nossa licença. Sendo o que o contrário fizesse pagaria seis mil reis para as obras deste conselho" ${ }^{268}$. A seca do ano anterior a essa determinação, $1692^{269}$, teria afetado as lavouras fazendo recrudescer a vigilância sobre gêneros de primeira necessidade. Anos mais tarde, diante de um princípio de carestia, a mesma municipalidade, mandava "reter nesta cidade o milho que houvesse vindo de fora e mais feijão", que deviam ser vendidos ao povo "pelo seu justo preço posto pelo Almotacé" 270 .

Em seu estudo sobre o mercado de farinha no Recôncavo, Barickman, aponta que a demanda urbana de farinha de Salvador abrangia os moradores permanentes da cidade e a população flutuante, formada por "escravos em trânsito, marinheiros, navios de partida e

\footnotetext{
${ }^{265}$ SALGADO, Graça. Fiscais e meirinhos: a administração no Brasil colonial. Rio de Janeiro: Nova Fronteira/ Arquivo Nacional, 1985, p. 135.

266 PEREIRA, Magnus Roberto de Mello - "Almuthasib - Considerações sobre o direito de almotaçaria nas cidades de Portugal e suas colônias”, en: Revista Brasileira de História, São Paulo: ANPUH, 2001, v. 21 , n. 42 , p. $379-380$.

${ }^{267}$ Idem.

${ }^{268}$ IHGRN - LTVSCN (1674 - 1698), Fl. 108v.Termo de Vereação 01 de junho de 1693.

${ }^{269}$ Ver o Quadro 01 no primeiro capítulo dessa dissertação.

270 APEJE - Ofícios do Governo (3) , Fl. 04. Recife 27 de maio de 1785. Carta circular que se escreveu aos ouvidores das quatro comarcas sobre a cultura das roças de mandioca.
} 
exportação"271. Diante dessa grande demanda, em finais do século XVIII, a própria população teria pressionado a câmara de Salvador para que exercesse um melhor controle sobre a saída da farinha que supria as embarcações durante as rotas de comércio de escravos ${ }^{272}$. Segundo Avanete Pereira Sousa, ao longo dos setecentos, os conflitos foram constantes entre os comerciantes envolvidos no trato de escravos e os camarários, que se empenhavam contra o desabastecimento de alimentos ${ }^{273}$.

A farinha de mandioca constituía um importante componente da alimentação nas embarcações envolvidas no tráfico, onde, conforme Alencastro, dava-se cerca de 1,8 litro de farinha diariamente a cada escravo ${ }^{274}$. Para garantir o aprovisionamento dos cativos na viagem de volta da África, as embarcações partiam carregadas com farinha dos seus portos de origem na América portuguesa ${ }^{275}$. A representação feita por um camarário de Salvador dá uma ideia da dimensão que esse mercado tinha para os gêneros alimentícios da região. Em 1754, o vereador Francisco Xavier informava sobre a falta de farinha de mandioca que se fazia sentir em Salvador, afetando "principalmente os rústicos, mulheres, meninos e escravos", acrescentando que:

este bem o costumam privar os senhorios dos navios, que navegam desta Cidade para a Costa da Mina e Angola, a resgate de escravos, extrahindo em cada um anno milhares e milhares de alqueires da dita farinha ${ }^{276}$.

Graças à dinâmica do seu porto, na Vila do Recife a demanda de mandioca não servia apenas ao consumo dos seus habitantes, mas era também um suporte fundamental no aprovisionamento das embarcações das rotas do Atlântico Sul ${ }^{277}$. Desde o início dos setecentos, as ameaças representadas pelas volumosas compras de farinha realizadas pelos comerciantes de escravos à estabilidade alimentar regional teriam motivado medidas que visavam contornar a situação, sem prejudicar o movimento de entrada de cativos. Já em 1723, a municipalidade do Recife escrevia ao Rei denunciando que a escassez de farinha se devia, em parte, às grandes

\footnotetext{
${ }^{271}$ BARICKMAN, B. J. Um Contraponto Baiano: Açúcar, Fumo, Mandioca e Escravidão no Recôncavo, 17801860. Rio de Janeiro: Civilização Brasileira, 2003, p. 99.

272 SOUSA, Avanete, Pereira. Poder local e vida cotidiana no Brasil colonial: o papel da Câmara Municipal na organização social da cidade de Salvador no século XVIII e início do XIX. Dissertação de mestrado. Salvador: UFBA/ FFCH/PPGH, 1996, p. 137- 139.

${ }^{273}$ SOUSA, Avanete, Pereira. Poder local e vida cotidiana no Brasil colonia... op cit, p. 137- 139.

274 ALENCASTRO, Luiz Felipe de. O trato dos viventes. Formação do Brasil no Atlântico Sul. Séculos XVI e XVII. São Paulo: Cia das Letras, 2010, p. 252.

275 BARICKMAN, B. J. Um Contraponto Baiano... op cit,, p. 99.

276 AHU - Bahia ( Eduardo de Castro Almeida), D. 13603. Salvador, 6 de novembro de 1754. Representação do Vereador da Caâmara da Bahia, Francisco Xavier de Araújo Lasso, protestando contra a extraordinária exportação de farinha de mandioca que se estava fazendo para a Costa da Mina e Angola.

${ }^{277}$ PALACIOS, Guillermo. Campesinato e Escravidão. op cit, p 58 - 59.
} 
quantidades embarcadas para abastecer as tripulações dos barcos das rotas de comércio de escravo com a Costa da Mina ${ }^{278}$. Dois anos depois, uma carta régia decretava que:

havendo para os homens de negócios, que navegão com pataxos e sumacas para a Costa da Mina, sítios capazes aonde possão fazer a planta que baste para o mantimento da viagem, sejão obrigados a fazer a roça ${ }^{279}$.

Apesar das determinações, negociantes envolvidos no tráfico continuaram a adquirir a farinha nos mercados locais ao longo dos setecentos. O desequilíbrio provocado no mercado regional de alimentos pela demanda que se originava no tráfico de escravos era uma perturbadora variável que acompanhava o próprio ritmo de entrada de cativos.

Não foram encontradas na documentação informações sobre o volume exato da farinha pernambucana direcionada para o tráfico de escravos. Entretanto, informações acerca das exportações anuais do gênero para portos africanos em $1796^{280}$ e $1798^{281}$, fornecidas pela documentação do Rio de Janeiro, ajudaram a construir uma estimativa da farinha adquirida pelos negociantes para cada escravo nas viagens atlânticas. Para isso, foram somados os alqueires de farinha exportada para os Portos de Angola e Benguela, em 1796 e 1798, e dividiuse essa soma pelo número de escravos que chegaram dos mesmos Portos, nos referidos anos ${ }^{282}$. A partir desses dados, chegou-se à estimativa de que cerca de 0,6 alqueires de farinha, aproximadamente 22 litros do gênero, eram adquiridos pelos negociantes para garantir o aprovisionamento de cada escravo na viagem de volta da África. Ao relacionar esse valor com o número de escravos importados pela capitania de Pernambuco, foi possível chegar ao volume aproximado de alqueires de farinha consumido pelo tráfico nas últimas décadas dos setecentos, conforme a tabela abaixo.

Tabela 3 - Escravos exportados para Pernambuco e a estimativa da farinha empregada no tráfico por ano $(1780$ - 1800)

\begin{tabular}{|c|c|c|}
\hline Ano & Escravos importados & Alqueires de farinha \\
\hline 1780 & 1.118 & 670,8 \\
\hline
\end{tabular}

\footnotetext{
${ }^{278}$ SOUZA, George. F. C. de. Saciar para manter a ordem e o bem público: a Câmara Municipal do Recife e o problema do abastecimento da vila (século XVIII). Locus (UFJF), v. 38 (2014) p. 125.

279 AHU - Avulsos de Pernambuco, D. 1864. Recife, 24 de julho de 1725. Carta do Governador da Capitania de Pernambuco, D. Manoel Rolim de Moura, ao rei, D. João V, sobre a aplicação da lei que obriga as pessoas que enviarem embarcações para a Costa da Mina a ter escravos efetivos no cultivo da farinha.

${ }^{280}$ AHU - Avulsos do Rio de Janeiro, D. 12025. Rio de Janeiro, 1796. Mapa do que se exportou do porto do Rio de Janeiro para os portos de Lisboa, Porto, Viana, Bahia, Angola e Benguela, no ano de 1796.

${ }^{281}$ AHU - Avulsos do Rio de Janeiro, D. 12689. Rio de Janeiro, 25 de maio de 1798. Ofício do Vice-rei do Estado do Brasil, conde de Resende, D. Luís de Castro, ao secretário de Estado da Marinha e Ultramar, D. Rodrigo de Sousa Coutinho, remetendo os mapas da exportação dos gêneros do Rio de Janeiro para portos brasileiros e portugueses.

282 Trans-Atlantic Slave Trade Database. Banco de dados, online, que registra viagens de tráfico de escravos. http://slavevoyages.org/. Acessado em 15/06/2020.
} 


\begin{tabular}{|c|c|c|}
\hline 1781 & 2.714 & $1.628,4$ \\
\hline 1782 & 2.557 & $1.534,2$ \\
\hline 1783 & 3.980 & 2.388 \\
\hline 1784 & 2.260 & 1.356 \\
\hline 1785 & 1.602 & 961,2 \\
\hline 1786 & 1.767 & $1.060,2$ \\
\hline 1787 & 6.120 & 3.672 \\
\hline 1788 & 3.182 & $1.909,2$ \\
\hline 1789 & 1.719 & $1.031,4$ \\
\hline 1790 & 2.664 & $1.598,4$ \\
\hline 1791 & 4.754 & $2.852,4$ \\
\hline 1792 & 4.057 & $2.234,2$ \\
\hline 1793 & 3.588 & $2.152,8$ \\
\hline 1794 & 1.775 & 1.065 \\
\hline 1795 & 4.526 & $2.715,6$ \\
\hline 1796 & 2.315 & 1.389 \\
\hline 1797 & 5.865 & 3.519 \\
\hline 1798 & 6.299 & $3.779,4$ \\
\hline 1799 & 3.468 & 2.080 .8 \\
\hline 1800 & 2.538 & $1.522,8$ \\
\hline
\end{tabular}

Fonte:Trans-Atlantic Slave Trade Database. Banco de dados, online, que registra viagens de tráfico de escravos. http://slavevoyages.org/. Acessado em 15/06/2020

Como se pode observar na Tabela 3, o comércio de escravos escoava milhares de alqueires de farinha de Pernambuco anualmente. As embarcações envolvidas no tráfico saíam carregadas de mantimentos do Porto do Recife, dessa forma, quanto maior o número de escravos importados, maior o volume de farinha adquirido no mercado local para a viagem de retorno do Continente africano. Os anos de 1791 e 1792, em especial, chamam a atenção, pelo elevado número de escravos importados e, consequentemente, pelo grande volume de farinha escoado pelo tráfico, que também pode ter contribuído para a fragilização do mercado de abastecimento durante a intempérie iniciada em 1791.

O escoamento de farinha para o abastecimento das populações flutuantes foi alvo de devida atenção da municipalidade do Recife ao longo dos setecentos. Em carta de 1785 o Ouvidor Geral de Pernambuco escrevia ao Senado da Câmara do Recife sobre não ser "juzto, que saia do Porto para fora para negócio o gênero da primeira necessidade, qual a farinha de pao deste Continente, e fiquem os habitantes dele padecendo" ${ }^{283}$. Diante disso, o ouvidor aconselhava que a municipalidade deveria solicitar ao Almotacé para "pôr o maior cuidado para que as embarcações, grandes, e pequenas, que saem deste Porto não levem mais fazenda do que

\footnotetext{
${ }^{283}$ IAHGP - LRCMR (1733-1808), Fls. 56 - 57v. Recife, 04 de janeiro de 1785. Registro de uma Carta do Doutor Desenbargador Ouvidor Geral, e Corregedor da Comarca José Pereira Barrozo de Miranda Leite
} 
aquela que for precisa para sustentação das respectivas tripulações na viagem". E caso o Almotacé, diante do "Povo grande", não conseguisse "pôr em execução" a determinação, deveria pedir auxílio militar ${ }^{284}$.

Segundo Flávio Marcus da Silva, nos setecentos, qualquer um que "comprasse mantimentos e os revendesse fora das regiões onde, pela lei deviam ser comercializados, sem que para isso tivesse licença das autoridades, era considerado um atravessador" ${ }^{285}$. A ação de "extrair mantimentos para fora", sem a licença do governo e das câmaras, era considerada um crime contra a ordem pública que deveria ser combatido. As autoridades coloniais buscaram com vigor combater as ações desses indivíduos. Da mesma forma, também buscaram coibir as atividades de alguns agentes que, mesmo com autorização para atuar, eram frequentemente acusados de comercializar os gêneros de primeira necessidade por preços maiores que os estipulados, como almocreves ${ }^{286}$, marchantes de gado e comissários.

Em carta escrita pelo Senado da Câmara do Recife ao Rei, em 1763, os camarários informavam que a carestia que se experimentava na farinha não era apenas fruto do baixo cultivo do gênero, mas da mesma maneira pelo fato de que "lavradores e almocreves, que os vendiam os podiam fazer pelos preços que lhes parecessem" ${ }^{287}$. Esses indivíduos impediam e resistiam à baixa dos preços estipulada pela câmara, publicados em editais públicos. Diante disso, a municipalidade solicitava, então, a imposição de novas penas não só "aos lavradores que não plantassem as lavouras suficientes", mas também àqueles que não taxassem "legumes e farinhas com preço certo" ${ }^{288}$. Mais uma vez, aqui fica clara a ideia que as autoridades tinham da obrigatoriedade de se manter um "preço justo" para a garantia do bem-estar comum, "dentro de um consenso popular a respeito do que eram práticas legítimas ou ilegítimas na atividade do mercado" 289 .

\footnotetext{
${ }^{284}$ IAHGP - LRCMR (1733-1808), Fls. 56 - 57v. Recife, 04 de janeiro de 1785. Registro de uma Carta do Doutor Desenbargador Ouvidor Geral, e Corregedor da Comarca José Pereira Barrozo de Miranda Leite.

285 SILVA, Flávio Marcus da. Subsistência e Poder: A política de abastecimento alimentas nas Minas setecentistas. Belo Horizonte: Editora UFMG, 2008, p. 110.

${ }^{286}$ Segundo dicionário da época, Almocreve seria, "homem, que conduz com bestas de carga". SILVA, Antônio de Moraes. Dicionário da Língua Portugueza Composto por Antônio de Moraes e Silva. Lisboa: Impressão Régia, 1831. $1^{\text {a }}$ edição de 1789 , v1, p. 63.

${ }^{287}$ AHU - Avulsos de Pernambuco, D. 7793. Recife, 23 de julho de 1763. Carta dos oficiais da câmara do Recife ao rei D. José, sobre a falta de plantações de mandiocas para o sustento das famílias devido aos estragos feitos pelos gados, e a imposição de novas penas para os lavradores que não plantarem lavouras suficiente para o bem comum e sustento de suas famílias.

${ }^{288}$ AHU - Avulsos de Pernambuco, D. 7793. Recife, 23 de julho de 1763. Carta dos oficiais da câmara do Recife ao rei D. José, sobre a falta de plantações de mandiocas para o sustento das famílias devido aos estragos feitos pelos gados, e a imposição de novas penas para os lavradores que não plantarem lavouras suficiente para o bem comum e sustento de suas famílias.

${ }^{289}$ THOMPSON, E. P. Costumes em comum. Estudos sobre a cultura popular tradicional. São Paulo: Companhia das Letras. 2008. p. 152.
} 
Numa tentativa de neutralizar a ação de um possível atravessador de farinha, em vereação de 5 de abril de 1788, a municipalidade da Vila de Natal acordava em "mandar passar mandato para João dos Santos" 290 . Segundo denúncias, o indivíduo, sem a autorização da Câmara ou do Governador, "na Ribeira desta estava comprando farinha para levar para as salinas". Diante disso, os camarários determinavam que fossem entregues quatro alqueires da farinha que "pretendia transportar para se repartir ao povo", e que caso não cumprisse a ordem, "fosse condenado em seis mil reis para a despesa deste Senado, ficando logo citado para venda e arrematação de qualquer bem aferido para este pagamento". Após a devolução da farinha, mediante acordo, o Senado da Câmara concedeu que o possível atravessador levasse apenas "um alqueire para sua viagem por levar junto oito pessoas consigo para este serviço" 291 .

Naquele mesmo ano, em edital lançado em 03 de janeiro, o Governador Geral de Pernambuco e Anexas, registrava que:

a experiência me tem mostrado que a carestia dos gêneros de primeira necessidade nas terras fecundas, a exceção de algum ano notoriamente calamitoso, não pode nascer de outra mais que das travessias e monopólios que se fazem em prejuízo irreparável do Povo inteiro e mais ainda dos indigentes e necessitados que com a perda da vida chegam a pagar a iniqua ambição daqueles indivíduos que destituídos de toda a humanidade estão de longe espreitando os gêneros de que o seu pais receia maior necessidade para neles empregarem os criminosos fundos que acumulara a sua avareza ${ }^{292}$

Segundo Dom Tomás, essas revendas de gêneros por preços mais altos eram ações comuns na Praça do Recife, em parte, graças a inexistência de "lugar certo e destinado para a venda e compra de seus víveres". Diante disso, o Governador destacava a importância da existência de mercados públicos, onde "cada um tenha a certeza de encontrar a melhor preço os gêneros que necessita sem suportar o lesivo excesso da segunda venda como acontece"293. Como forma de remediar a situação e melhor fiscalizar o comércio de gêneros de primeira necessidade, evitando os excessos praticados, Dom Tomás José de Mello determinava que "nem uma pessoa de qualquer qualidade que seja possa vender nem comprar farinha, feijão, arroz e milho fora da praça da Polé, ou seja, introduzido por água ou por terra" ${ }^{\text {294 }}$. Além disso, pelo mesmo Edital, ordenava-se sobre o abastecimento da carne, indicando que ninguém pudesse

\footnotetext{
${ }^{290}$ IHGRN - LTVSCN (1784 - 1803), Fls. 74 v - 75 .Termo de Vereação de 05 de abril de 1788.

${ }^{291}$ IHGRN - LTVSCN (1784 - 1803), Fls. 74 v - 75 .Termo de Vereação de 05 de abril de 1788.

292 APEJE - Registro de Provisões, Portarias, Editais e Bandos. R.Pro. 4/2, Fl. 6v. Recife 03 de janeiro de 1788. Edital sobre se não poder vender nem comprar farinha, arroz, feijão, e milho fora da praça da Polé, e a carne no açougue público, como também as penas que culminam aos atravessadores destes gêneros.

${ }^{293}$ APEJE - Registro de Provisões, Portarias, Editais e Bandos. R.Pro. 4/2, Fl. 6v. Recife 03 de janeiro de 1788. Edital sobre se não poder vender nem comprar farinha, arroz, feijão, e milho fora da praça da Polé, e a carne no açougue público, como também as penas que culminam aos atravessadores destes gêneros.

${ }^{294}$ Idem.
} 
vendê-la "em sua casa, ou outra qualquer parte fora do açougue público". Aqueles que desobedecessem seriam punidos "debaixo da pena de dez mil reis pagos na Cadeia pela primeira vez, ficando ao meu arbítrio o mais castigo que me parecer”. Em relação à venda de carne em lugares impróprios, além da multa, o vendedor ou vendeira perderia a carne, indo "metade para o denunciante e a outra para os metade para os presos da cadeia"295.

A praça da Polé, estipulada pelo Governador como ponto fixo para a venda de gêneros alimentícios no Recife, era conhecida como Terreiro dos Coqueiros durante o período Holandês, e naquele tempo já funcionava como ponto de comércio na Cidade Maurícia. O local foi, inclusive, retratado em um dos famosos quadros de Franz Post (Figura 1), onde uma incomum aglomeração pode ser observada, parecendo representar uma espécie de feira de rua.

\section{Figura 1 - O terreiro dos Coqueiros em 1641}

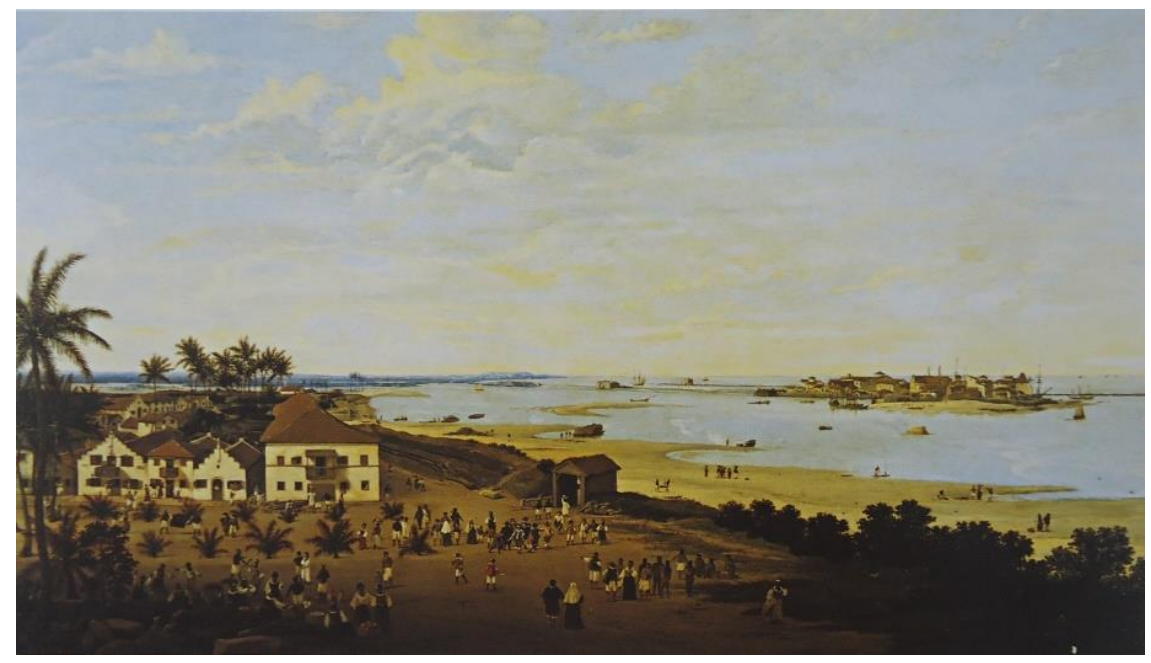

Fonte: CORRÊA DO LAGO, Bia; CORRÊA DO LAGO, Pedro. Frans Post (1612-1680): obra completa. Rio de Janeiro: Capivara, 2006.

A prática de estipular um lugar fixo para a venda de víveres essenciais para o aprovisionamento da população era uma maneira de estimular uma comercialização feita de forma direta, se possível direcionada pelos próprios produtores, sem a ação de intermediários que podiam almejar maiores lucros. Limitar as vendas a uma área restrita também consistia em uma eficaz estratégia de facilitação da fiscalização das práticas comerciais.

$\mathrm{Na}$ discussão que aqui se desenvolveu fica claro o contínuo esforço empregado pelas autoridades das capitanias de Pernambuco e anexas para assegurar um fornecimento regular de

\footnotetext{
295 APEJE - Registro de Provisões, Portarias, Editais e Bandos. R.Pro. 4/2, Fl. 6v. Recife 03 de janeiro de 1788. Edital sobre se não poder vender nem comprar farinha, arroz, feijão, e milho fora da praça da Polé, e a carne no açougue público, como também as penas que culminam aos atravessadores destes gêneros.
} 
gêneros alimentícios nas vilas da sua jurisdição. Apesar das sucessivas, e até mesmo repetitivas, determinações, o aprovisionamento estável da capitania deparou-se com certos obstáculos. Nesse sentido, ao longo dos setecentos, o cultivo de alimentos foi constantemente preterido diante dos gêneros de exportação, com a recusa da grande lavoura em produzir para o seu próprio abastecimento e fornecer excedentes para a população, bem como com a transferência de tradicionais lavradores de alimentos para as culturas de exportação. O baixo cultivo de alimentos no sertão era também um problema, uma vez que a demanda da região terminava por pressionar outras zonas produtoras. Com relação ao escoamento de gêneros de primeira necessidade, as autoridades municipais e da capitania tiveram que lidar com os entraves provocados pelo consumo de farinha pelo tráfico, exportações irregulares, assim como as ações ilícitas de comerciantes, que visavam o aumento dos preços estipulados para auferir maiores lucros.

A última década do século XVIII foi particularmente problemática para o abastecimento da Capitania Geral de Pernambuco. Somando-se à ocorrência de adversidades climáticas, uma conjuntura internacional favorável para a agricultura de exportação, e a disseminação de uma cultura de fácil adaptação à região e altamente demandada pelo mercado europeu, constitui-se como um entrave a mais para um abastecimento alimentar estável em Pernambuco e Anexas.

\section{A “ambição do algodão" e a retração na produção de alimentos}

Essencialmente tropical, a variedade arbórea do algodão já era conhecida no Brasil pelos indígenas que a utilizavam em rama e através de fiação rudimentar faziam cordas e redes para dormir e pescar ${ }^{296}$. Ao longo dos séculos XVI e XVII, houve uma pequena produção do gênero, porém em escala reduzida e com uma utilização restrita, voltada ao mercado local, destinado ao fabrico de tecidos grosseiros para vestir escravos e a população mais pobre ${ }^{297}$.

Foi a partir da segunda metade do século XVIII que a cotonicultura passou a ter uma maior relevância econômica, sobretudo de 1776 em diante, quando a Guerra de Independência dos Estados Unidos foi deflagrada, anulando temporariamente um dos principais fornecedores da fibra essencial para as fábricas têxteis inglesas. Diante disso, em finais da década de 1770, a partir do estímulo do monopólio da Companhia Geral de

\footnotetext{
296 ARRUDA, José Jobson de Andrade. A produção econômica. In: SILVA, M. B. N. da. (org). Nova História da expansão portuguesa. O Império Luso-Brasileiro (1750-1822). Lisboa: Estampa, 1986, p. 102- 103.

${ }^{297}$ RIBEIRO Jr. José. A economia algodoeira em Pernambuco. Da Colônia à independência. Revista Brasileira de História, v. 2 (set. 1981)1, p. 237-239
} 
Comércio de Pernambuco e Paraíba, os agricultores já eram incentivados a "plantarem todo o algodão que admitissem as suas terras segundo o número de seus escravos" ${ }^{298}$. Como um dos encarregados pelo estímulo à disseminação da cultura, o Ouvidor Geral de Pernambuco enaltecia facilidade da agricultura do algodão, apontando que a fibra poderia, inclusive, ser desenvolvida nos mesmos terrenos em que a mandioca era cultivada, nos "extremos da mesma planta sem que prejudique as manivas" 299 .

De acordo com o relato feito em finais de setecentos por Manuel Arruda Camara em seu "Memória sobre a cultura dos algodoeiros", o único instrumento necessário para plantação dos algodoeiros era a enxada, e que o número de "quatro pessoas armadas deste instrumento bastam para plantar o maior campo de algodão"300. Depois de abertas covas rasas, de no máximo quatro polegadas de profundidade, lançavam-se as sementes e as cobriam de terra fazendo uso dos próprios pés ${ }^{301}$.

Depois de crescidos, os algodoeiros necessitavam de cuidados, exigindo apenas três processos básicos. O primeiro processo era a capação, que consistia na retirada do "olho" da planta quando a mesma alcançava determinada altura, fazendo com que o algodoeiro produzisse mais galhos laterais ${ }^{302}$. O próximo procedimento que deveria ser feito era a poda, quando chegassem as primeiras chuvas, e os galhos que já haviam produzido eram $\operatorname{cortados}^{303}$. Por fim, o último processo consistia na decotação, ato de cortar o algodoeiro pelo tronco, geralmente após o quarto ano de colheita, para que novos galhos pudessem nascer $^{304}$. Com esses procedimentos, o mesmo algodoeiro podia produzir por três anos seguidos ou mais. Para a colheita, quando se via o "algodoal branquejar, de modo que se

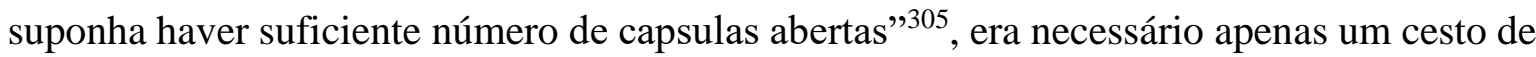
capacidade de uma arroba, e um escravo ou agricultor livre que fizesse uso "unicamente de três dedos" para puxar o caroço da fibra ${ }^{306}$.

Como se pode ver, o algodão era um gênero de agricultura fácil, e não demandava muitos braços de trabalho, com capacidade de despertar o interesse de agricultores livres e

\footnotetext{
298 AHU - Avulsos de Pernambuco, D. 9561. Recife, 25 de fevereiro de 1777. Oficio do Governador sobre se introduzir a cultura do algodão e do arroz na dita capitania e anexa.

299 AHU - Avulsos de Pernambuco, D. 9561. Recife, 25 de fevereiro de 1777. Oficio do Governador sobre se introduzir a cultura do algodão e do arroz na dita capitania e anexa.

300 CÂMARA, Manuel Arruda da. Obras reunidas c. 1752-1811. Coligidas e com estudo biográfico por José Antonio Gonsalves de Mello. Recife: Fundação de Cultura Cidade do Recife, 1982, p. 131.

${ }^{301}$ Idem.

${ }^{302}$ Ibidem, p. $132-133$.

${ }^{303}$ Ibidem, p. 134.

${ }^{304}$ CÂMARA, Manuel Arruda da. Obras reunidas...Op. cit, p. 134.

305 Ibidem, p. $146-147$.

${ }^{306}$ Idem.
} 
senhores de pequenos e médios plantéis de escravos. A sua cultura permitia, assim, a possibilidade de aproveitamento de pequenas e medias extensões de terra e de mão de obra menos numerosas. Outra facilidade do cultivo do algodoeiro consistia no fato de que o mesmo se aclimatava facilmente a regiões mais secas, onde "não há multiplicidade de serra, e os campos são mais espaçosos, as chuvas não são tantas, a tempérie do ar é seca e quente"307. Diante dessa característica, segundo Câmara, "nos anos de 1777 até 1781 animaram-se os povos de uma nova força, então é que se viram os interiores dos Sertões mais habitados e cultivados" 308 .

Os algodoais foram fixando-se pelo agreste, avançando progressivamente para os sertões, em terras próximas aos currais. Sua implementação nessas regiões teria ocorrido justamente durante uma seca que se arrastou entre os anos de 1776 e 1777 . Tal fato teria, segundo Luciana Frota, atestado a resistência da cultura diante da ação de intempéries fazendo com que a mesma passasse a ser vista como uma possível "geradora de riquezas", estimulando a população cearense a se dedicar ao plantio da fibra ${ }^{309}$.

Alguns anos após o início do seu cultivo, o Capitão-Mor do Ceará informava que aquela capitania que antes se dedicava apenas "na criação dos gados e na sua matança nos Portos" naquele momento também se empenhava na "rica cultura do algodão" e que era "tal a sua abundância e boa qualidade que no mesmo Brasil tem aprimorada reputação" ${ }^{310}$. Sobre isso, um raciocínio de Denise Monteiro a respeito da introdução do cultivo da fibra no Rio Grande do Norte pode ser muito bem utilizado em referência a realidade cearense. Segundo Monteiro, em finais de setecentos, uma economia que até então era baseada principalmente na criação de gados diversificou-se e "era a primeira vez, desde o início do povoamento europeu, que um produto era cultivado em larga escala, visando uma exportação para o exterior", como "agricultura mercantil"311.

A facilidade da manutenção dos algodoeiros, que não necessitava de muitos braços, e a sua adaptabilidade a terrenos menos férteis e climas mais seco, que possibilitava o seu plantio em terras que antes não eram interessantes para a agricultura, foram essenciais para

\footnotetext{
${ }^{307}$ CÂMARA, Manuel Arruda da. Obras reunidas...Op. cit, p. 134, p. 128.

${ }^{308}$ Ibidem, p. 117.

${ }^{309}$ FROTA, Luciara Silveira de Aragão . Estudo do Remanejamento da Pecuária na Zona Norte do Ceará - $1^{\circ}$ volume. 1786. Fortaleza: Superintendência do Desenvolvimento do Estado do Ceará (SUDEC) \& Universidade Vale do Acaraú, 1974.

${ }^{310}$ AHU - Ceará, D. 590. Ceará, s/d 1782. Ofício do capitão-mor do Ceará, João Batista de Azevedo Coutinho de Montauri, a Martinho de Melo e Castro, sobre as condições de abastecimento.

311 MONTEIRO, Denise Mattos. Introdução à História do Rio Grande do Norte. Natal: EDUFRN, 2002, p. 79 80.
} 
a introdução da cultura do algodão e sua disseminação em Pernambuco e Anexas. Entretanto, para além dos atributos físicos do algodoeiro, uma conjuntura internacional para o mercado da fibra também foi de grande importância para o incremento da agricultura do algodão a partir da década de 1780 .

As últimas décadas do século XVIII foram marcadas pela expansão das exportações brasileiras, com o florescimento das sementes plantadas pelas reformas de Pombal e o resultado de novas oportunidades no mercado internacional para os produtos coloniais. A circulação de ideias de caráter fisiocrático que refletiam sobre as condições de produção, e sobre a necessidade de maiores investimentos na agricultura ${ }^{312}$, juntamente com uma conjuntura econômica internacional de valorização dos produtos coloniais, teriam corroborado para o incremento da produção agrícola voltada para a exportação. Assim, com a diversificação dos gêneros agrícolas, estimulada desde as companhias pombalinas ${ }^{313}$, as exportações dos já tradicionais produtos brasileiros - açúcar e tabaco - eram acompanhadas por gêneros como o algodão, o café, o cacau e o anil, que até o momento não se configuravam como artigos de exportação importantes.

A conjuntura internacional favorável para o cultivo do algodão e o crescimento da demanda internacional do produto pode ser justificada pelo grande empuxo ocorrido nas manufaturas têxteis inglesas após 1780. Segundo Thales Pereira, o crescimento das exportações de algodão da América Portuguesa estava relacionado a mudanças na qualidade dos tecidos durante os primeiros estágios da revolução industrial ${ }^{314}$. O surgimento de panos mais finos e de melhor qualidade após a década de 1780, requeriam uma variedade diferente do algodão anteriormente usado na Inglaterra. A qualidade da fibra da colônia portuguesa, mais longa e resistente, tinha uma vantagem natural diante das espécies cultivadas em outras regiões, respondendo rapidamente à crescente demanda europeia ${ }^{315}$. Alcançando, em Pernambuco, o crescimento produtivo supreendente de $329 \%$ entre 1780 e $1790^{316}$.

Ao dissertar sobre a situação econômica do Ceará, o Ouvidor Geral da capitania, Manuel Avelar, estava otimista diante das potencialidades oferecidas pelo cultivo do

\footnotetext{
312 PEDREIRA, Jorge Miguel Viana. “Agrarismo, Industrialismo, Liberalismo: algumas notas sobre o pensamento económico português (1780-1820)". In CARDOSO, J. L. (org.). Contribuição para a História do Pensamento Económico em Portugal. Lisboa: Dom Quixote, 1988, p. 63-74.

${ }^{313}$ Idem.

${ }^{314}$ PEREIRA, Thales. The Cotton trade and Brazilian foreign commerce during the Industrial Revolution. Tese de doutoramento. São Paulo: USP/FEA/PPGE, 2017, p. 24 -26.

315 Ibidem, p. 24 -26.

${ }^{316}$ MELO, Felipe Souza. O negócio de Pernambuco: financiamento, comércio e transporte na segunda metade do século XVIII. Dissertação de mestrado. São Paulo: USP/FFLCH/PPGHE, 2017, p. 167.
} 
algodão. Avelar registrava que as Câmaras deveriam atuar para "animar e promover a nova plantação dos algodões desta capitania, a qual tendo em vista o que atualmente é e o que pode vir a ser é inegável que por pouco que se animasse se tornaria um dos ramos mais importantes do comercio do Brasil para Portugal"317. O ouvidor argumentava que, "não tendo principiado esta plantação mais que a 4 ou 5 anos para cá", e mesmo sem receber o incentivo e a proteção das autoridades, a cultura do algodão já estava presente "em toda a beira mar da capitania" e sertões. Isso acontecia visto que, diante de outros gêneros, a facilidade do cultivo da fibra "agradava mais o ânimo ocioso dos habitantes", pois não exigia deles "outro serviço manual que a plantação e colheita e durando esta por espaço de dez anos uma vez que foram plantados os arbustos". Ademais, diante da acelerada e profícua disseminação da cultura, Manuel Avelar, informava que "hão de colher para cima de 30.000 arrobas" 318 .

Não tão otimista quanto o ouvidor do Ceará, em ofício de 1787, endereçado ao Secretário de estado da Marinha e Ultramar, o governador da Paraíba, coronel Jerônimo José de Mello e Castro, demonstrava certa preocupação diante da rápida difusão da agricultura do algodoeiro na capitania. Segundo o Governador, alguns produtores de açúcar estavam se dedicando ao cultivo da fibra, e apesar dos pedidos feitos para que "continuasse e se não apartassem para a planta do algodão", tal troca veio a causar uma baixa "em mais de dez mil cruzados" nos Dizimos Reais do açúcar ${ }^{319}$. Ao longo da década de 1790 a produção do algodão, de fato, ultrapassou a do açúcar, e em 1798 a capitania exportava 8.556 quintais de açúcar e 12.852 quintais de algodão. É importante salientar que cerca de 35\% do algodão exportado naquele ano saiu das vilas do sertão paraibano, reiterando a sua adaptabilidade e produtividade em terras sertanejas ${ }^{320}$.

Acerca do desenvolvimento da produção do algodão em detrimento do açúcar, D. Tomás José de Mello, Governador de Pernambuco, em parecer econômico, registrava que o incremento do cultivo da fibra se dava "em relação ao maior preço do algodão, (pois) seriam ainda necessárias muito mais arrobas de açúcar para o seu equivalente, do que se manifesta

\footnotetext{
317 AHU - Ceará, D. 644. Quixeramobim, 03 de fevereiro de 1787. Carta do Ouvidor do Ceará Manuel Avelar, à Rainha D. Maria, sobre a situação econômica da referida capitania.

318 AHU - Ceará, D. 644. Quixeramobim, 03 de fevereiro de 1787. Carta do Ouvidor do Ceará Manuel Avelar, à Rainha D. Maria, sobre a situação econômica da referida capitania.

319 AHU - Paraíba, D. 2173. Paraíba, 12 de abril de 1787. Oficio do Governador da Paraíba, coronel Jeronimo José de Melo e Castro, informando dos problemas de jurisdição de um governo subornidano.

${ }^{320}$ AHU - Paraíba, D. 2510. Paraíba, 31 de julho. Ofício do governador da Paraíba Fernando Delgado Freire de Castilho, ao secretário de Estado da Marinha e Ultramar, Rodrigo de Sousa Coutinho, remetendo mapas gerais relativos aos preço, à exportação, à importação, ao movimento marítimo, à população, aos nascimentos, casamentos, mortes e à ocupação dos habitantes da Paraíba.
} 
que a balança ainda pende muito a favor do algodão"321 . Além das condições de mercado do algodão, D. Tomás também elencava como motivo para a animação da produção as baixas despesas para o cultivo do gênero, acrescentando que "por isso sempre o lavrador interessará mais na cultura do algodão, que na da cana"322.

Entretanto, a disseminação do algodão não desviou apenas terras e braços da cana, e os gêneros de primeira necessidade também foram preteridos diante do cultivo da fibra. A fácil agricultura do algodão e a sua plena capacidade de desenvolvimento em terrenos menos férteis teria despertado o interesse de agricultores livres e pequenos proprietário de escravos, que reduziram sua produção de gêneros de primeira necessidade e passaram a se concentrar na lavoura algodoeira ${ }^{323}$.

Em ofício encaminhado ao secretário de estado da Marinha Ultramar, o Governador da Paraíba, Jerônimo José de Melo e Castro, queixava-se de os "agricultores desampararem o seu fundamento da plantagem na Mandioca, prejuízo da paixão e única ambição do Algodão, só se empregam na plantagem do mesmo algodão abandonando juntamente a cultura do Açúcar". Segundo o Governador, a retração da produção da mandioca já fazia o preço da farinha subir, que chegava a ser vendida por mais de dois mil reis, quando o seu regular preço era seiscentos e quarenta réis" 324 , o que representou um aumento de cerca de $315 \%$ no preço do produto naquele ano.

Em resposta a esse movimento, as autoridades coloniais desencadearam uma série de medidas destinadas a frear a disseminação do algodão entre os lavradores de mandioca e recompor a oferta de alimentos para os portos exportadores, plantations açucareiras e população. Voltou-se a regulamentar sobre o cultivo obrigatório de mandioca, bem como a instaurar campanhas de recrutamento compulsório com a finalidade de desorganizar a produção de algodão ${ }^{325}$. O recrutamento era particularmente grave para a população pauperizada, incluindo uma parcela de agricultores livres, porque a retirava de seus afazeres, impossibilitando-a de garantir o seu sustento.

Diante da contínua deterioração da produção de alimentos, graças a sua troca pela

\footnotetext{
321 AHU- Pernambuco, D. 13658. Recife, 10 de janeiro de 1798. Ofício do Governador da Capitania de Pernambuco, D. Tomás José de Melo, ao Secretário de Estado da Marinha e Ultramar, informando o parecer sobre a situação econômica da Capitania de Pernambuco.

322 AHU- Pernambuco, D. 13658. Recife, 10 de janeiro de 1798. Ofício do Governador da Capitania de Pernambuco, D. Tomás José de Melo, ao Secretário de Estado da Marinha e Ultramar, informando o parecer sobre a situação econômica da Capitania de Pernambuco.

${ }^{323}$ PALACIOS, Guillermo. Campesinato e Escravidão. op cit, p. 130 -134.

${ }^{324}$ AHU - Paraíba, D. 2178. Paraíba, 28 de maio de 1787. Oficio do governador da Paraíba ao secretario de estado da Marinha e Ultramar, informando da preferência dos lavradores em cultivar o algodão.

${ }^{325}$ PALACIOS, Guillermo. Campesinato e Escravidão... op cit, p. 150 -154.
} 
cultura do algodão, o então governador de Pernambuco, José César de Menezes, em carta dirigida às câmaras de Olinda e Igarassu ordenou "suspender até decisão minha a planta de algodão nesse distrito à toda aquela pessoa que não tiver de seis escravos para cima"326. A pena estipulada pelo governador para aqueles que desobedecessem foi a prisão e, além disso, a instrução dizia que os agricultores e lavradores "obrando em contrário lhe seriam arrancados os algodões e reduzidos a cinzas"327. De forma semelhante, ao constatar o crescimento da produção do algodão em detrimento da mandioca, o governador da Paraíba lançou edital ordenando que

cada um casal seja obrigado a plantar e cultivar cinco mil covas de mandioca e tendo filhos ou escravos capazes de trabalho, cada um plante e cultive três mil covas e isto indispensavelmente não lhe proibindo a plantagem do algodão a que puderem chegar as suas forças ${ }^{328}$

Além de atentar para a obrigação do cultivo de mandioca, que naquele momento era ofuscado pelas vantagens do cultivo da fibra do algodoeiro, as autoridades buscavam aumentar a oferta da farinha nos centros urbanos, com o intuito de evitar a chegada de uma crise. Diante disso, em 1790, contra a ganância daqueles que se tornavam "inimigos de si e dos seus semelhantes" o Governo de Pernambuco ordenou que nenhuma pessoa, "seja qualquer que for sua qualidade", poderia conduzir para a Praça do Recife "algodão algum, colhido em esta Comarca, Itamaracá e Goiana, por mar ou terra, sem que igualmente conduza a quarta parte do número das cargas de farinha, ou a correspondente" ${ }^{329}$. Além disso, por edital de 1788 o mesmo Governo concedeu a todas pessoas que "provassem ter remetido para o mercado do Recife 300 alqueires de farinha por safra ou por ano, a graça de ficarem isentos do serviço militar, assim como seus filhos" ${ }^{330}$.

Apesar das tentativas de conter a "ambição do algodão" dos lavradores, a troca das roças de mandioca e demais alimentos pelos algodoais continuou a acontecer, fragilizando o abastecimento de alimentos. A este respeito, já em 1797, o governador Thomas José de Mello escreveu à rainha que apesar da imposição de que "apenas lavradores de mais de seis escravos

\footnotetext{
${ }^{326}$ APEJE - Ofícios do Governo (4), fl 102 . Recife, 14 de fevereiro de 1785. Carta do Governador de Pernambuco às Câmaras de Igarassu e Olinda.

${ }^{327}$ APEJE - Ofícios do Governo (4), fl 102 . Recife, 14 de fevereiro de 1785. Carta do Governador de Pernambuco às Câmaras de Igarassu e Olinda.

${ }^{328}$ AHU - Paraíba, D. 2178. Paraíba, 28 de maio de 1787. Oficio do governador da Paraíba ao secretario de estado da Marinha e Ultramar, informando da preferência dos lavradores em cultivar o algodão.

329 APEJE - Registro de Provisões, Portarias, Editais e Bandos, 4/2, fl 85 . Recife , 09 de maio de 1790. Edital sobre a cultura da roça de Mandioca e condução da farinha com o Algodão.

${ }^{330}$ COSTA, Francisco Augusto Pereira. Anais Pernambucanos. v. 6. Recife: Secretaria do Interior e Justiça, 19511966, p. 398.
} 
se ocupassem na lavoura do algodão", debaixo de graves penas, “o mal já tinha causado raízes mui profundas"331.

Para além de ser uma economia de Antigo Regime, os principais problemas da produção de alimentos em finais dos setecentos estavam ligados a uma questão ampla de caráter estrutural, dentro da qual se situava a dominância da grande agricultura voltada para a exportação, a valorização dos seus produtos e sua crescente expansão. Dessa dominância decorrem vários fatores: a recusa dos grandes senhores das propriedades monocultoras de produzir para a própria subsistência e com excedentes para o mercado interno, apesar das ordens da das autoridades coloniais; as vantagens oferecidas pelas culturas de exportação, que impunham uma utilização intensa de mão-de-obra na agricultura especulativa; a transferência da produção dos agricultores especializados em alimentos para o cultivo do algodão, estimulados pelos seus preços e pela alta demanda do mercado europeu pela fibra. Além dos problemas da produção, a oferta de alimentos no mercado regional também tinha outros entraves, como a grande demanda de gêneros pelo tráfico, e a ação de monopolistas e açambarcadores, que reduziam a oferta de mantimentos para a população e faziam surgir a carestia. Todos esses fatores contribuíam para a irregularidade do abastecimento local, bastando a chegada de um fenômeno desorganizador, como a seca, para lançar toda a população numa crise alimentar.

\footnotetext{
${ }^{331}$ AHU - Avulsos de Pernambuco D. 13603. Recife, 21 de agosto de 1797. Carta do governador da capitania de Pernambuco, D. Tomás José de Melo, à rainha, D. Maria I, informando seu parecer expedido pela câmara do Recife, referente a proibição da entrada de carga de algodão sem levar também a farinha de mandioca.
} 


\section{Capítulo 3. A grande Seca de 1791 na Capitania de Pernambuco e Anexas}

A seca é um fenômeno natural recorrente no mundo todo, e se caracteriza por um período prolongado, geralmente uma estação ou mais, de baixa ou ausência de pluviosidade, onde a perda da umidade do solo é superior à sua reposição. Seus impactos são o resultado da interação entre o evento natural (menos chuvas que o esperado), e a demanda da população para o uso da água ${ }^{332}$. A seca seria, segundo Mike Davis, um "duelo recorrente entre a natural variabilidade de chuvas e as defesas hidráulicas da agricultura" ${ }^{\text {"33 }}$. Num contexto onde se concentra ainda uma sociedade marcadamente agrária, com o uso de práticas rudimentares de cultivo e pecuária, o clima e seus ritmos são fundamentais para o estabelecimento de boas e más colheitas. Dessa forma, longos períodos de estiagem podiam frustrar safras, debilitar a pecuária, e trazer inúmeras consequências socioeconômicas para as regiões atingidas, aumentando a probabilidade de uma crise surgir.

O presente capítulo tem como principal objetivo analisar a "grande seca" de 1791 e as suas implicações para as capitanias de Pernambuco e Anexas. Entretanto, para isso, primeiramente se faz necessário compreender como se originavam e desenvolviam as crises em sociedades e economias predominantemente agrícolas.

\section{As crises de "tipo antigo"}

Estudos diversos sobre as economias antigas de estrutura agrícola dominante têm demonstrado a importância dos movimentos das colheitas nessas sociedades e as suas multiplicidades de efeitos econômicos e sociais. Os impactos causados pela variabilidade das colheitas nas sociedades dos séculos XVI, XVII, XVIII e inícios do XIX, bem como seus principais mecanismos, foram expostos desde cedo pelos contemporâneos que vivenciaram as suas consequências. Desse modo, nas últimas décadas dos seiscentos, Gregory King já apontava em suas estatísticas sobre a economia inglesa que a perda de colheitas de trigo produzia um aumento correlativo nos preços do gênero ${ }^{334}$. Além de King, Turgot também descreveu os efeitos das crises consequentes da perda de colheitas e do aumento dos preços dos alimentos, segundo o estudioso: “o consumidor que paga pelo pão mais caro reduz suas outras despesas, em particular aquelas relacionadas a objetos fabricados e causa uma crise de subconsumo que

\footnotetext{
332 MARENGO, José.; TORRES, Roger.; ALVES, Lincoln. Drought in Northeast Brazil - past, presente and future. Theoretical and Applied Climatology, v.20, 2016, p. 3-5.

${ }^{333}$ DAVIS, Mike. Holocaustos Coloniais. op. cit. p 28.

${ }^{334}$ JONGMAN, W. DEKKER, R. Public intervention in the food suply in pre-industrial Europe. In: HALSTEAD, Paul. O'SHEA, John. (Orgs) . Bad year economics: cultural responses to risk and uncertainty. Cambridge: Press Syndicate of the University of Cambridge, 2004, p. 117.
} 
leva ao desemprego" 335 . Concomitante às ideias de Turgot, François Quesnay e diversos economistas do século XVIII também dedicaram estudos ao que era considerado um problema central na época: a instabilidade das colheitas e dos preços dos gêneros de primeira necessidade e a política de subsistência ${ }^{336}$.

A partir dos registros deixados por esses estudiosos e de dados referentes ao ciclo das colheitas e preços registrados na Europa do Antigo Regime, Ernest Labrousse desenvolveu uma teoria que culminou com a tese de que durante o período pré-industrial o ritmo da conjuntura era determinado pelo sucesso ou fracasso de colheitas. Segundo o autor, com a perda de colheitas, ou a sua redução, a produção de grãos caía bastante, e a escassez de alimentos conduzia a uma elevação nos seus preços ${ }^{337}$. As consequências sobre os preços dependiam da extensão dos danos às plantações, e segundo a dimensão do déficit (ou do excedente), os preços dos cereais podiam subir (ou baixar), de maneira sobre proporcional.

Com relação ao mercado de cereais europeu, Gregory King estimou que uma redução de $10 \%$ na produção de trigo resultava em aumentos de preços de cerca de 30\%, uma redução de $20 \%$, por sua vez, elevava os valores em $80 \%$ e que uma redução de $30 \%$ produzia o aumento de impressionantes $450 \%$ nos preços ${ }^{338}$. Por outro lado, boas colheitas eram capazes de produzir uma queda nos preços, favorecendo o aprovisionamento da população menos abastada, mas trazendo desvantagens para alguns produtores. Ao versar sobre as crises e conjunturas na Europa central, Abel apontou que as crises agrícolas podiam favorecer os grandes proprietários, que produziam volumes maiores de excedentes, pois mesmo com a queda na produção a alta nos preços era capaz de compensar o volume mais baixo de gêneros ofertados, e a depender do percentual da colheita, alcançavam maiores lucros que em anos de colheitas normais ${ }^{339}$. Por outro lado, aqueles com a colheita insuficiente não tinham nada para vender e às vezes precisavam comprar os gêneros para consumo próprio, forçando ainda mais os preços para $\operatorname{cima}^{340}$.

A extensão e a intensidade da alta nos preços dos alimentos, e consequentemente a crise, vinculavam-se claramente à dependência em relação a um tipo único de vegetal: os cereais.

\footnotetext{
${ }^{335}$ LABROUSSE, Ernest. Esquisse du mouvement des prix et des revenus en France au XVIIIe siècle. Paris : Éditions des Archives Contemporaines, 1984, p. 540-541.

${ }^{336}$ QUESNAY, François. François Quesnay et la physiocratie. Paris: INED, p. 427. apud FLORESCANO, Henrique. Precios del maíz y crisis agrícolas en México (1708-1810). Cidade do México: Ediciones Era, 1986, p. 120 .

${ }^{337}$ LABROUSSE, Ernest. Fluctuaciones economicas e historia social. Tecnos, 1973.p. 13- 14.

${ }^{338}$ ABEL, Wilhelm. La agricultura: sus crisis y coyunturas. Cidade do México: fondo de Cultura Económica, 1986, p. 27.

${ }^{339}$ Idem .

${ }^{340}$ VILLAR, Pierre. Iniciación al vocabulario del análisis histórico. Barcelona: Crítica, 1999, p. 99 - 101.
} 
Conforme já foi visto anteriormente, as sociedades dominantemente agrícolas possuíam um alimento, geralmente fonte rica de carboidratos, como base do regime alimentar. Dessa forma, a inelasticidade da demanda, juntamente com o papel central dos cereais na dieta alimentícia e o temor causado pela probabilidade da falta de pão, faziam dos grãos um gênero bastante sensível à evolução das colheitas e às circunstâncias do abastecimento, componentes importantes da oferta ${ }^{341}$. Um simples boato sobre más colheitas e escassez era suficiente para aumentar os preços e, por outro lado, a notícia da chegada de uma carga do gênero poderia bastar para provocar uma queda nos $\operatorname{preços}^{342}$. Apesar da oscilação, os consumidores não podiam reduzir a sua demanda proporcionalmente a elevação do valor, pois o alimento era um gênero básico e essencial para a sobrevivência.

A oferta de gêneros de primeira necessidade conservava, assim, uma evidente dependência das colheitas, e estas, por sua vez, flutuavam em função de alguns fatores potencialmente perturbadores da produção. Entre esses fatores se encontravam principalmente as guerras e as causas naturais, como chuvas fortes, secas, geadas, furacões e pragas agrícolas. A fragilidade da estrutura produtiva podia permitir que o clima desempenhasse um papel importante no desencadeamento das crises.

A ação das perturbações meteorológicas sobre as colheitas e a carestia de alimentos decorrente da mesma era potencialmente problemática nas sociedades dominantemente agrícolas. Depois da catástrofe que reduzia as colheitas, uma série de efeitos inter-relacionados se encadeava. Nos centros urbanos, com o início da crise, aponta Florescano, os mais abastados realizavam grandes compras com o objetivo de se preparar para os dias mais difíceis, o que causava o aceleramento da escassez e a alta dos preços, agravando a situação do consumidor pobre $^{343}$. Já para a população urbana menos abastada, o aumento excessivo nos gêneros alimentícios podia significar a fome imediata, tornando-as as primeiras vítimas da crise. Esses contingentes esfomeados, por sua vez, causavam um estado de tensão nas cidades, aumentando a probabilidade de saques e tumultos ${ }^{344}$.

Quando as notícias de uma colheita desfavorável chegavam às cidades, as autoridades locais ordenavam que fossem feitas grandes compras nos centros produtores que ainda

\footnotetext{
341 ABEL, Wilhelm. Agrarkrisen und Agrarkonjunktur. Goettingen: Vendonhoel, 1979, p. 134 apud SILVA, Francisco Carlos Teixeira da. A Morfologia da Escassez: crises de subsistência e política econômica no Brasil colônia (Salvador e Rio de Janeiro, 1680-1790). Tese de doutoramento. Niterói: UFF/ICHF/PPGHIS, 1990, p. 379

342 BENITO I MONCLÚS, Pere. Crisis alimentarias en la Edad Media: modelos, explicaciones y representaciones, Lleida, Milenio, 2013: 15-32.

${ }^{343}$ FLORESCANO, Henrique. Precios del maíz y crisis agrícolas en México (1708-1810). Cidade do México: Ediciones Era, 1986, p. 141.

${ }^{344}$ FLORESCANO, Henrique. Precios del maíz... op. cit,, p. 155.
} 
possuíam gêneros remanescentes. Conforme já foi visto, tal medida poderia ser vantajosa para os grandes produtores, que conseguiam muitas vezes compensar as perdas na produção com a elevação dos preços, por outro lado, quando a crise alcançava sua intensidade máxima, muitos pequenos e médios agricultores viam suas reservas esgotadas e terminavam vendendo seus bens até chegar à miséria ${ }^{345}$. Em alguns casos, restava apenas o recurso da imigração às cidades, onde as reservas de alimentos poderiam ser maiores, fazendo aumentar o número de "vadios" nos centros urbanos ${ }^{346}$.

Depois dos efeitos econômicos sentia-se, às vezes quase que simultaneamente, os efeitos sociais e demográficos da crise. Os desajustes estruturais inerentes às sociedades de Antigo Regime se intensificavam diante da pressão da conjuntura, das "crises de tipo antigo". A intensidade da perturbação meteorológica associada à fragilidade do sistema produtivo podia fazer surgir de forma encadeada: escassez, carestia, fome, morte do gado, epidemias, aumento da taxa de mortalidade, grandes deslocamentos de população, mal estar social, aumento da criminalidade e tensão política. Assim, cada crise era o resultado da combinação específica de uma variedade de causas que atuavam em níveis e maneiras distintas.

Com relação à América portuguesa, Maria Yedda Linhares e Francisco Teixeira apontaram que as crises alimentares que afligiam a colônia podiam ser atribuídas a quatro fatores: causas naturais, como imprevistos climáticos, pragas, secas e epidemias que afetavam a população; recusa do lavrador em plantar gêneros para além do seu autoconsumo; concorrência desfavorável entra a agricultura de gêneros de primeira necessidade e a agricultura extensiva exportadora, voltada para os impulsos do mercado internacional; surgimento de um mercado mais lucrativo, que levava o produtor a transferir os seus gêneros do mercado local para outro $^{347}$.

A interveniência climática era um fenômeno periódico nas capitanias de Pernambuco e anexas, e o sistema alimentar deveria ser capaz de funcionar nessas condições. Ocorre que, durante a seca de 1791 a produção de alimentos apresentava de forma permanente, conforme já foi visto, um funcionamento entravado por óbices diversos, como a recusa de agricultores em produzir excedentes e a preferência dada ao cultivo de gêneros demandados pelo mercado internacional, como o açúcar e, posteriormente, o algodão, em detrimento dos gêneros de

\footnotetext{
${ }^{345}$ ABEL, Wilhelm. La agricultura: sus crisis y coyunturas. Fondo de Cultura Económica, 1986, p. 27.

${ }^{346}$ FLORESCANO, Henrique. Precios del maíz... op. cit, p. 127.

347 LINHARES, Maria Yedda. SILVA, Francisco Carlos Teixeira da. História da Agricultura Brasileira: Combates e Controvérsias. São Paulo: Brasiliense, 1981, p. 162-163.
} 
primeira necessidade. Dessa forma, a fragilidade da estrutura produtiva permitiu que a flutuação do clima desempenhasse um importante papel no surgimento da crise.

\section{Seca, agricultura de alimentos e desabastecimento}

A perturbação meteorológica que desencadeou a seca de três anos de duração teve princípio em 1791, com chuvas irregulares e limitadas, de tal maneira que "plantagens e sementeiras não produziram todas" ${ }^{348}$. Essa redução inicial no volume de chuvas atrapalhava o desenvolvimento das plantações, produzindo uma safra abaixo do esperado, e muito reduzida de gêneros. No ano seguinte, teria se sucedido uma rigorosa seca, "assolando toda a zona que se estende das Alagoas ao Ceará, só terminando em fins de 1793, causando em toda essa região incalculáveis prejuízos" 349 .

Suficientemente longa, a seca de três anos teria inutilizado grandes extensões de roças de primeira necessidade. Sobre a intempérie, o governador da Capitania Geral de Pernambuco, D. Tomás José de Melo, escreveu que:

as graves secas destes anos sucessivos que tiveram princípio em noventa e hum e findarão em noventa e três desta sorte arruinaram esta capitania e a sua população (...) sendo por esta causa ainda a farinha de pao tão escassa que nem para municiar diariamente as tropas pagas como é de obrigação a posso adquirir ${ }^{350}$.

Considerada de cultivo fácil e resistente, a mandioca se destacava entre outras culturas alimentares por sua grande resistência à seca. Em tempos de poucas chuvas, um pé de mandioca raramente morria, apenas perdia as suas folhas, permanecendo inerte, mas revivendo rapidamente com o retorno das chuvas ${ }^{351}$. Contudo, a persistência da estiagem prejudicava a sua lavoura, uma vez que sem chuvas as manivas, tocos de caules usados no plantio, não germinavam, inutilizando a sua plantação. Ademais, a falta de chuva endurecia os solos, o que dificultava a sua colheita, e em casos extremos a tornava impossível. A perda dessas lavouras reduzia a oferta de gêneros e provocava um aumento excessivo nos preços dos alimentos.

\footnotetext{
${ }^{348}$ PEREIRA, Joaquim José. Memória sobre a extrema fome e triste situação em que se achava o sertão da Ribeira do Apody. In: Revista do Instituto Histórico e Geográfico Brasileiro. Tomo LXII, p. 177.

${ }^{349}$ COSTA, Francisco Augusto Pereira. Anais Pernambucanos. v. 1. Recife: Secretaria do Interior e Justiça, 19511966, p. 503.

${ }^{350}$ AHU - Avulsos de Pernambuco, D. 13117. Recife, 15 de setembro de 1795. OFÍCIO do governador da Capitania de Pernambuco, D. Tomás José de Melo, ao secretário do estado dos Negócios Estrangeiros e da Guerra e interinamente da Marinha e Ultramar, Luís Pinto de Sousa Coutinho, sobre as providências que tomou em relação a cultura de mandioca, informando que a seca que assolou a Capitania nos últimos anos deixou a terra estéril e matou a terça parte da população.

${ }^{351}$ BARICKMAN, B. J. Um Contraponto Baiano... op. cit, p. 90-91.
} 
Em um cenário de crise de abastecimento pode-se identificar três situações diferenciadas: penúria, carestia e fome. A penúria seria um estado de falta ou necessidade de um gênero em uma determinada região, uma situação movediça, que pode evoluir rapidamente à normalidade ou agravar-se. Já a carestia pode ser compreendida como uma situação em que os gêneros básicos para a sobrevivência da população aumentam o dobro, o triplo. Enquanto a fome pode ser entendida como uma situação na qual os alimentos, mesmo por muito dinheiro, não podem ser comprados ${ }^{352}$. Assim, a falta de um gênero, penúria, seria seguida pela alta do seu preço, carestia, onde a permanência nesse estado levaria a uma situação de fome, que por ser superlativa por natureza, não comportaria graus diferentes de análise.

Em 1793, a Câmara de Montemor-o-novo, no Ceará, informava sobre o lastimável estado em que a vila se encontrava graças a "mais vigorosa e longa seca". Os efeitos imediatos da estiagem haviam sido a falta de pasto e água para o sustento dos animais e manutenção das lavouras. O baixo volume de chuvas teria reduzido bastante a produção de mantimentos, levando a uma alta nos seus preços, fazendo surgir a carestia, "não havendo já espécie alguma de legumes ou víveres que não subisse 200 ou 300 por cento mais do que seu valor preterido" 353. Apesar dos altos preços de alimentos, "não podia escusar-se individuo algum do diário sustento e era indispensável o comprá-lo" 354 .

As regiões mais interioranas e afastadas do centro administrativo da Capitania Geral de Pernambuco se encontravam mais vulneráveis à penúria e a carestia desencadeadas pela estiagem, pois possuíam um acesso mais difícil ao fluxo de gêneros direcionados de outras zonas produtoras. Na supracitada Montemor-o-novo, os Camarários queixavam-se que, diante da improdutividade da terra, por mais que "intentassem uma centena de vezes os seus agricultores" foi subindo desproporcionalmente o valor da farinha de mandioca e, apesar de ter o seu preço fixado pelas autoridades em 1280 reis o alqueire, alcançava até 10.000 reis o alqueire $^{355}$. Além dos altos preços, naquele momento da crise ficava cada vez mais difícil

\footnotetext{
352 ABEL, Wilhelm. Massenarmut und Hungerkrisen im vorindustriellen Deutschaland. Goettigen: Vandenhoeck und Ruprecht, 1977, p. 37. Apud. SILVA, Francisco Carlos Teixeira da.op. cit, p. 05- 07.

${ }^{353}$ AHU - Avulsos (BG), D. 2345. Lisboa , 25 de janeiro de 1793. Consulta do Conselho Ultramarino à rainha (D. Maria) sobre a carta do juiz e mais oficiais da Câmara da Vila de Montemor-o-novo, da capitania de Pernambuco acerca do estado miserável que se acham reduzidos os moradores daquele continente, por causa da seca que assola a região desde 1791, os sucessivos roubos dos malfeitores e as execuções que fazem os credores.

${ }^{354}$ AHU - Avulsos (BG), D. 2345. Lisboa , 25 de janeiro de 1793. Consulta do Conselho Ultramarino à rainha (D. Maria) sobre a carta do juiz e mais oficiais da Câmara da Vila de Montemor-o-novo, da capitania de Pernambuco acerca do estado miserável que se acham reduzidos os moradores daquele continente, por causa da seca que assola a região desde 1791, os sucessivos roubos dos malfeitores e as execuções que fazem os credores.

${ }^{355}$ AHU - Avulsos (BG), D. 2345. Lisboa , 25 de janeiro de 1793. Consulta do Conselho Ultramarino à rainha (D. Maria) sobre a carta do juiz e mais oficiais da Câmara da Vila de Montemor-o-novo, da capitania de Pernambuco
} 
encontrar o gênero para compra, mesmo assim, algumas cargas estavam sendo encaminhadas para o Porto do Recife vindas da Bahia e do Rio de Janeiro "com quem os desta capitania tem pouca correspondência e experimenta por isso maior necessidade que o Recife de Pernambuco de onde por apertadas ordens é proibido conduzi-las para esta capitania"356. Diante disso, o Senado da Câmara acusava o Governador Geral de Pernambuco de querer "primeiro acudir os seus", e apontava que a contínua despesa gerada pela compra de víveres a altos preços, aproximava abastados e pobres, "confundidos na miséria", onde "os primeiros desapropriaram seus melhores móveis e os últimos descansavam eternamente" 357.

Com a alta dos preços, nem todos conseguiam ter acesso aos gêneros adequados e necessários à sobrevivência, e a fome causada pela estiagem terminava por impor a muitos uma morte na mingua. Na dieta do desespero qualquer coisa servia como comida. Em junho de 1793, a câmara de Pilar do Taipu, na capitania da Paraíba, informava sobre os males causados pela estiagem na região, durante a qual muitos estariam perecendo diante "de diversas epidemias originadas da terrível estação e do ordinário uso de malignas e silvestres raízes pela falta do comum alimento" ${ }^{358}$. Segundo Joffily, os três anos da "grande seca" na Paraíba teriam sido marcados por inúmeras doenças e mortes causadas pela ingestão de alimentos impróprios, como “macuná, xique-xique, potó e por muitas outras plantas silvestres de que usavam os famintos" 359. Apontamentos semelhantes foram feitos pelo Padre Joaquin José Pereira, testemunha ocular da seca no Apodi. Segundo o Padre:

Os agrestes e desconhecidos alimentos, por suas qualidades causaram deletérios na saúde e vida d'aquelles habitadores, e produziam neles inchações disformes, vômitos de sangue extraordinários, desinterias ferinas, males cutâneos cruéis, marasmos últimos; vindo por este motivo a povoarem as sepulturas dos campos e dos povoados ${ }^{360}$.

Quando a seca alcançava a sua intensidade máxima, e as regiões mais vulneráveis viam suas reservas esgotadas e os preços dos alimentos cada vez mais altos, a alternativa para muitos era seguir para vilas e freguesias que haviam sofrido menos com os impactos da estiagem,

acerca do estado miserável que se acham reduzidos os moradores daquele continente, por causa da seca que assola a região desde 1791, os sucessivos roubos dos malfeitores e as execuções que fazem os credores

${ }^{356}$ AHU - Avulsos (BG), D. 2345. Lisboa , 25 de janeiro de 1793. Consulta do Conselho Ultramarino à rainha (D. Maria) sobre a carta do juiz e mais oficiais da Câmara da Vila de Montemor-o-novo, da capitania de Pernambuco acerca do estado miserável que se acham reduzidos os moradores daquele continente, por causa da seca que assola a região desde 1791, os sucessivos roubos dos malfeitores e as execuções que fazem os credores.

357 Idem.

358 AHU - Avulsos da Paraíba, D. 2286. Paraíba. 8 de junho de 1793. Carta dos oficiais da Câmara da Paraíba, à Rainha (D. Maria I), informando da calamidade que a seca trouxe à vila do Pilar do Taipu; e queixando-se dos procedimentos do governador da Paraíba para sanar os problemas da estiagem.

${ }^{359}$ JOFFILY, Irenêo. Notas sobre a Parahyba. Brasília, Thesourus, s/d, p. 433.

${ }^{360}$ PEREIRA, Joaquim José. Memória ... op. cit, p. 179. 
especialmente no litoral. Em relato sobre os males causados pela seca, Feo Torres, então Governador do Ceará, apontou que a migração para outras regiões era uma estratégia empregada por uma parcela da população como tentativa de sobreviver à intempérie. Segundo Torres, como consequência da destruição de pastos e lavouras observava-se "uma grande parte destes povos na precisão de emigrarem de umas para outras terras", mesmo assim, graças à rigorosidade da crise, muitos terminavam "encontrando em toda a parte a dura fome" ${ }^{361}$. Ao presenciar semelhante peregrinação de pessoas em busca de sobrevivência no Apodi, o Padre Joaquim José Pereira registrou que:

Tais quaes outras formigas errantes dos seus formigueiros pareciam as famílias d'quelle sertão, procurando o sustento a aventura, cruzando os caminhos e nelle encontrado-se umas com as outras. Pelas estradas se viam os mortos, uns aqui outros acolá, que pareciam querer despovoar os termos e capitanias de seus domicílios ${ }^{362}$.

Em busca de refúgio e mantimentos nas cidades, essas levas de pessoas tencionavam ainda mais o já problemático mercado de abastecimento, acarretando uma elevação ainda maior dos preços dos alimentos, aprofundando a crise nos centros urbanos. A este respeito, o Governador da Paraíba escreveu ao secretário de Estado da Marinha e Ultramar que apesar dos constantes esforços empregados para impulsionar a oferta de alimentos e acudir os menos abastados, a crise teria se agravado "com as inumeráveis famílias que dos sertões descerão para os contornos das praias" ${ }^{363}$. Segundo o Governador, a chegada desses sertanejos à Cidade da Paraíba, além de elevar a demanda por alimentos, pressionando o mercado de abastecimento local, teria "multiplicado as desordens" na região ${ }^{364}$. Assim, com a continuidade da crise, a crescente aglomeração de pessoas nas cidades amplificava as tensões sociais.

Em seu estudo sobre as crises alimentares no México, Florescano destacou o aumento do bandoleirismo em tempos de escassez. Segundo o autor, o crescimento da criminalidade seria proporcional à elevação dos preços dos gêneros de primeira necessidade, uma vez que diante da impossibilidade de garantir a compra do alimento necessário os menos abastados

\footnotetext{
${ }^{361}$ Carta de Feo e Torres a Martinho de Mello e Castro dando conta dos atos de sua administração, 1792. Apud STUDART, Guilherme. Notas para a História do Ceará. Lisboa: Typographia do Recreo, 1892, p.422

362 PEREIRA, Joaquim José. Memória. In: Revista do Instituto Histórico e Geográfico Brasileiro. Tomo LXII, p. 179.

363 AHU - Avulsos da Paraíba, D. 2354. 19 de abril de 1796. OFÍCIO do Governador da Paraíba, Brigadeiro Jerónimo José de Melo e Castro, ao Secretário de estado da Marinha e Ultramar, Luís Pinto de Sousa Coutinho, informando da calamidade que trouxe a seca, destruindo as colheitas e o gado, trazendo um número enorme de pessoas para o litoral.

${ }^{364}$ Idem.
} 
terminavam por recorrer ao roubo e ao furto para sobreviver ${ }^{365}$. Durante a crise iniciada pela seca em 1791, um movimento similar pôde ser observado, e em toda a extensão de Pernambuco e anexas foi perceptível o aumento da ocorrência de crimes, em especial furtos e roubos de mantimentos, como estoques de farinha, plantações de gêneros alimentícios e gado.

Em fevereiro de 1792, o Governador de Pernambuco baixou uma Portaria determinando que o Capitão Mor de Olinda, juntamente com o Comandante do Beberibe, soldados da ordenança e oficiais se direcionassem à Mata da Mirueira "por constar que ali andam várias pessoas armadas tomando as farinha que os homens do Mato conduzem para esta Praça". Para evitar maiores desordens, os militares deveriam atuar "colhendo alguns delinquentes e os remeter presos e bem seguros a minha presença para os castigar como me parecer" ${ }^{366}$. Através da documentação não foi possível saber se os "delinquentes" acusados pelo roubo da farinha intentavam revender o gênero, auferindo assim maiores lucros com a crise, ou simplesmente consumi-lo para remediar a fome. De qualquer forma, esse evento é útil para compreender a inquietação causada pela seca nos centros urbanos, bem como para perceber as ações empreendidas pelas autoridades para assegurar a manutenção da ordem pública.

A capitania da Paraíba também foi palco de um evento que muito bem reflete a forte tensão que a seca, a carestia e a penúria produziam. Em 1792, os índios da Vila do Conde e Alhandra desesperados e sem alternativas para a fome, repartiram-se em bandos e "levantaramse a furtar descaradamente e a seu exemplo brancos, pardos e pretos dizendo que na necessidade todos os bens são comuns" ${ }^{367}$. Cerca de um ano depois, aproximando-se do fim da seca, movimento semelhante ainda era observado no Ceará. Os camarários da Vila de Motemor-oNovo descreveram de forma detalhada para o Secretário de Estado da Marinha e Ultramar a situação da Vila diante do aumento da criminalidade decorrente da aguda crise:

levantou-se em toda esta capitania uma espessa nuvem de malfeitores, assassinando e roubando tudo o que podem: eles usam da libertinagem em todo o seu rigor, não tomam o que lhes é preciso, porque nesse caso seriam desculpáveis. Depois eles acabaram os gados, que por escaparem da seca se refugiarão em alguns lugares ocultos e frescos passaram aos domésticos das fábricas das fazendas e engenhos e ainda não satisfeitos com isto eles passam a arruinar as lavoiras de roça e canaviais que se conservavam em alguns

\footnotetext{
365 FLORESCANO, Henrique. Precios del maíz y crisis agrícolas en México (1708-1810). Cidade do México: Ediciones Era, 1986, p. 169.

366 APEJE - Registro de Provisões, Portarias, Editais e Bandos. R.Pro. 4/2, Fl. 6v. Recife, 18 de fevereiro de 1792. Portaria para o Capitão Mor da Cidade de Olinda e comandante de Beberibe passassem à Mata da Mirueira para executar o que ela contém.

${ }^{367}$ AHU - Avulsos da Paraíba, D. 2268. Paraiba, 17 de julho de 1792. Oficio do Governador da Paraiba, coronel Jerónimo José de Melo e Castro, ao secretario de estado da Marinha e Ultramar, Martinho de Melo e Castro, informando da fome na capitania, com os mais sofridos a roubarem alimentos; e ter escrito ao governo da Bahia em busca de socorro, pedindo dois navios de farinha.
} 
lugares mais húmidos para de todo senão acabarem as sementes e poderem replantar-se quando as estações tornassem favoráveis ${ }^{368}$.

Como se pode observar, a seca e a crise de abastecimento consequente da mesma teriam incrementado o número de desordens, principalmente aquelas relacionadas ao roubo de gêneros alimentícios. O desespero causado pela carestia e pela fome impelia, assim, muitos a buscarem meios alternativos de sobrevivência, inclusive à margem da lei.

As poucas lavouras e estoques de gêneros alimentícios que haviam sobrevivido à seca consistiam em reservas essenciais para remediar a fome no âmbito local, e a extração desses gêneros para outras regiões ficava terminantemente proibida, pois facilitava a ação de monopolistas e reduzia ainda mais a oferta de gêneros para a população. Dessa forma, além de tornarem-se alvos de constantes furtos, as roças e as reservas de farinha remanescentes configuraram-se como objetos de disputas pelas autoridades locais, que buscavam atender as necessidades daqueles que se encontravam sob a sua jurisdição.

Durante longa estiagem, Jerônimo de Castro e Mello, então governador da Paraíba, queixava-se da contínua extração de farinha para fora da capitania, apesar das proibições que havia feito. Mais especificamente, o governador se referia à condução de farinha que estava sendo realizada da Vila de Alhandra, onde existiriam duas "roças capazes de repararem a extrema necessidade destes povos", para a vila de Goiana a mando do Capitão mor da mesma, que por sua vez cumpria ordens do Governo Geral de Pernambuco. Alegando que não havia outro lugar com reservas de farinhas na capitania, Castro e Mello, também indicava para o fato de que, separada da Vila de Goiana pelo rio Popoca, Alhandra se encontrava sob domínio paraibano, e requeria que o governador de Pernambuco, desse a devida providência para que o capitão mor de Goiana “se não se intrometa na jurisdição desse governo". Em resposta, Tomás José de Mello escreveu que:

a necessidade e miséria a que se acha reduzida a sua e esta capitania com a falta de farinha, não admite a disputa em que V. $S^{\mathrm{a}}$. quer entrar de pertencer ou não pertencer ao seu governo o distrito de Agoa Comprida, mas sim procurar os meios mais eficazes e prontos com que se socorram uns e outros Povos, que todos são vassalos da mesma Soberana e merecem a mesma contemplação ${ }^{369}$

\footnotetext{
${ }^{368}$ AHU - Avulsos (BG), D. 2345. Lisboa , 25 de janeiro de 1794. Consulta do Conselho Ultramarino à rainha (D. Maria) sobre a carta do juiz e mais oficiais da Câmara da Vila de Montemor-o-novo, da capitania de Pernambuco acerca do estado miserável que se acham reduzidos os moradores daquele continente, por causa da seca que assola a região desde 1791, os sucessivos roubos dos malfeitores e as execuções que fazem os credores

${ }^{369}$ AHU - Avulsos da Paraíba, D. 2258. Paraíba, 21 de abril de 1792. Ofício do Governador da Paraíba, Coronel Jeronimo José de Melo e Castro ao Secretário de Estado Da Marinha e Ultramar, Matinho de Melo e Castro, informando da falta de farinha, provocada pela seca.
} 
Ademais, o governador de Pernambuco acrescentava que fossem de "Goiana ou da Paraíba na presente situação acho justo que os Povos dessa capitania se socorram destes Distritos da farinha que puderem alcançar" ${ }^{\prime 370}$. Nessas circunstâncias, permitia que Castro e Mello continuasse a socorrer o seu povo com as ditas farinhas, desde que não pusesse empecilhos à condução deste gênero para a Praça do Recife, "para socorrer vinte e oito mil almas que tem esta Villa, dois Regimentos pagos, um corpo de Artilharia e três Hospitais a que de necessidade se há de acudir" ${ }^{371}$.

Apesar do estado de miséria, disputas e desorganização social causado pela seca, havia quem visse na intempérie uma oportunidade de negócios. Os altos preços alcançados pelos gêneros alimentícios atraíram a atenção de atravessadores e açambarcadores que almejavam angariar lucros ainda maiores com a penúria e a carestia que assolavam a região. A este respeito, um episódio ocorrido na capitania da Paraíba chama a atenção pelo possível envolvimento de uma autoridade local com a travessia e o açambarcamento de alimentos. Em carta endereçada à rainha, a Câmara da Cidade da Paraíba, acusava o então Governador da capitania da Paraíba, Jerônimo de Melo e Castro, de favorecer e se envolver no "monopólio da farinha". Segundo os vereadores, logo que a farinha começou a faltar "pela entrada da seca no ano de 91", Melo e Castro ordenou que os roceiros levassem ao palácio do governo "uma ou duas cargas do sobredito gênero todas as semanas para se repartir com o povo, e tropas pagas", entretanto se distribuía apenas dois alqueires ao povo, e recolhiam-se as demais sacas ${ }^{372}$. O restante da carga seria, então, enviado a Manoel Cavalcante de Araújo, tenente do Presídio de Cabedelo, que vendia a farinha "pelo miúdo" chegando a lucrar até oito mil réis por alqueire. Segundo o Senado da Câmara, o mesmo teria acontecido com uma carga de 900 alqueires de farinha chegada pelo porto, da qual o Governador teria feito recolher 500 alqueires para o municiamento da tropa, repassando apenas 150, e guardando o restante para "assistir a manobra das farinhas". Os procedimentos do Governador, "mais forte partidista deste monopólio",

\footnotetext{
${ }^{370}$ AHU - Avulsos da Paraíba, D. 2258. Paraíba, 21 de abril de 1792. Ofício do Governador da Paraíba, Coronel Jeronimo José de Melo e Castro ao Secretário de Estado Da Marinha e Ultramar, Matinho de Melo e Castro, informando da falta de farinha, provocada pela seca

${ }^{371}$ AHU - Avulsos da Paraíba, D. 2258. Paraíba, 21 de abril de 1792. Ofício do Governador da Paraíba, Coronel Jeronimo José de Melo e Castro ao Secretário de Estado Da Marinha e Ultramar, Matinho de Melo e Castro, informando da falta de farinha, provocada pela seca.

${ }^{372}$ AHU - Avulsos da Paraíba, D. 2287. Paraíba, 26 de junho de 1793. Carta dos oficiais da Câmara da Paraíba à rainha, D. Maria, informando das calamidades da seca, e queixando-se dos procedimentos vexatórios tomados pelo governador da Paraíba, Brigadeiro Jerônimo de Melo e Castro.
} 
teriam "reduzido o povo a um estado ainda mais lamentável" 373 . Além de desviar os gêneros que deveriam ser repartidos entre a população menos abastada, a ação de atravessadores e açambarcadores fazia aumentar a carestia, contribuindo para a manutenção e até o agravamento da crise.

Apesar do episódio acima narrado, ao longo da crise boa parte das autoridades coloniais trabalharam constantemente para amenizar os seus efeitos para a população, em especial para os pobres, mais vulneráveis às oscilações na produção de alimentos. Visando coibir a ação daqueles que almejavam enriquecer a custa da crise alimentar, os açambarcadores acusados de estocarem farinha em Pernambuco "foram recolhidos à cadeia e carregados de ferros, e a farinha que se lhes achou tomada por perdida e o seu produto aplicado para os lázaros de Santo Amaro". Foi ordenado que todos denunciassem a quantidade de farinha que tinham e que a venda do gênero, "então mui escasso", fosse realizada exclusivamente na Praça da Polé, e que aqueles que desobedecessem às ordens pagassem 10.000 reis na cadeia ${ }^{374}$. A respeito das determinações feitas sobre a venda de farinha durante a seca Studart conta que:

pelas 11 horas do dia soltava-se um foguete no ar, a este sinal chamava os compradores ao mercado. Um piquete de infantaria, comandado por oficial, tinha a seu cargo não só a polícia do mercado, mas igualmente proibir que a pessoa alguma se vendesse mais de um salamim de farinha, devendo os pobres ser os primeiros servidos; de maneira que quer os ricos mandassem seus escravos quer fossem pessoalmente eram eles sempre os últimos que compravam $^{375}$.

A partir dessas determinações as autoridades buscavam evitar que grandes quantidades de gêneros fossem vendidas para poucas pessoas, o que poderia facilitar a ação de monopolistas, bem como garantir que as camadas menos abastadas tivessem acesso ao gênero necessário para o seu sustento, comprando "à miúdo". Entretanto, além de organizar o funcionamento da compra e venda de alimentos durante a crise, também era necessário garantir que uma oferta de gêneros minimamente suficiente chegasse ao mercado local.

Salvaguardar os gêneros que ainda se encontravam nos campos e garantir que os mesmos fossem encaminhados diretamente a população foi uma das medidas adotadas pelas autoridades na tentativa de remediar a crise. Em junho de 1792, o então Governador da Paraíba, junto com ordens de produção de farinha, vigilância nas roças e multas reservadas aos que não

\footnotetext{
${ }^{373}$ AHU - Avulsos da Paraíba, , D. 2287 Paraíba, 26 de junho de 1793. Carta dos oficiais da Câmara da Paraíbaà rainha, D. Maria, informando das calamidades da seca, e queixando-se dos procedimentos vexatórios tomados pelo governador da Paraíba, Brigadeiro Jerônimo de Melo e Castro.

${ }^{374}$ COSTA, Francisco Augusto Pereira. Anais Pernambucanos. v. 6. Recife: Secretaria do Interior e Justiça, 19511966, p. 139.

${ }^{375}$ STUDART, Guilherme. Notas para a História do Ceará. Brasília: Edições do Senado Federal, 2004 , p. 423.
} 
obedeciam às determinações ${ }^{376}$, "para o sustento das tropas e clamorosa pobreza da cidade" mandou examinar as roças dos fabricantes de farinhas que haviam restado, fintando-os semanalmente em alqueires de acordo com a sua força produtiva. Tais medidas não foram muito bem aceitas por alguns produtores, que se recusavam a remeter os gêneros estipulados, acusando o Governador de ameaçar a liberdade de comércio. Aqueles se recusaram a cumprir as ordens terminaram presos na Fortaleza de Cabedelo ${ }^{377}$. Além disso, estipulou-se que o preço do alqueire de farinha deveria ser vendido a 1.280 réis, mesma taxa do Recife. Entretanto, segundo o Governador, apesar do tabelamento do preço do gênero, "a necessidade das gentes a vinha comprar a este mesmo distrito até quatro mil reis o alqueire" ${ }^{378}$.

Diante da grave escassez de gêneros, consequência da destruição de plantações pela seca, as autoridades coloniais atuaram para impedir que os gêneros que haviam restado fossem desviados para outras regiões, o que poderia agravar a escassez e elevar ainda mais os preços. Em vereação de 23 de dezembro de 1792, o Senado da Câmara de Natal determinou que o almotacé vigiasse a ribeira da cidade, pois no local "constava haver peixe seco para embarcar para fora". Após impedir a saída da embarcação, o almotacé deveria fazer o capitão "vender o peixe ao povo pela grande fome que há na capitania pela seca" ${ }^{379}$. Alguns meses depois, medida semelhante foi tomada pela municipalidade em relação a um barco que transportava arroz, cuja carga foi retirada e repartida entre o povo ${ }^{380}$.

Além de impedir a saída de mantimentos para outras regiões, embargar e requisitar as cargas de embarcações que passavam pelos portos foi outro recurso adotado pelas autoridades para incrementar o volume de gêneros disponíveis no mercado local. Em 21 de janeiro de 1792, diante da "bem notória falta de farinha, que esta Vila e seu termo experimentam pela esterilidade do tempo", o Senado da Câmara do Recife solicitava ao governador que permitisse embargar a farinha de uma embarcação que seguia da Bahia para o Presídio de Fernando de Noronha, que se encontrava no Porto da Vila. Segundo os camarários, a distribuição da dita

\footnotetext{
376 AHU - Avulsos da Paraíba, D. 2286. Paraíba. 8 de junho de 1793. Carta dos oficiais da Câmara da Paraíba, à Rainha (D. Maria I), informando da calamidade que a seca trouxe à vila do Pilar do Taipu; e queixando-se dos procedimentos do governador da Paraíba para sanar os problemas da estiagem.

${ }^{377}$ AHU - Avulsos da Paraíba, D. 2254. Paraíba, 14 de março de 1792. Ofício do Governador da Paraíba, coronel Jeronimo José de Melo e Castro, informando dos males da seca e da finta que lançou sobre os fabricantes de farinha no contorno da cidade, inclusive da prisão de um dos fintados.

378 AHU - Avulsos da Paraíba, D. 2258. Paraíba, 21 de abril de 1792. Ofício do Governador da Paraíba, Coronel Jeronimo José de Melo e Castro ao Secretário de Estado Da Marinha e Ultramar, Matinho de Melo e Castro, informando da falta de farinha, provocada pela seca.

${ }^{379}$ IHGRN - LTVSCN (1748 - 1803), fl. 167.Termo de Vereação de 23 de dezembro de 1791.

${ }^{380}$ IHGRN - LTVSCN (1748 - 1803), fl. 170v. Termo de Vereação de 10 de março de 1792
} 
farinha seria capaz de remediar "a fome, de que este Povo se queixa" 381 . Após a autorização do Governo, os 604 alqueires de farinha da embarcação foram vendidos à miúdo ao povo, dandose sempre preferência ao mais pobres ${ }^{382}$. Pouco mais de um mês depois, pela grande "necessidade de farinha e mais comestivos de que os moradores deste termo sentem", a Câmara do Recife embargou a "farinha e mais comestivos" de um bergantim proveniente de Santa Catarina, que havia se aproximado do Porto do Recife para reparos ${ }^{383}$. Estabeleceu-se, então, um acordo com o capitão da embarcação, ficando estabelecido que o dinheiro arrecadado com a venda dos mil e quinhentos alqueires de farinha seria usado para reembolsar o dono da carga e reparar os danos da embarcação ${ }^{384}$.

Apesar das medidas tomadas para aumentar o volume de alimentos e garantir uma oferta regular para a população, as reservas locais de mantimentos continuaram insuficientes. Diante disso, restava às autoridades coloniais solicitar diretamente o envio de farinhas e demais gêneros alimentícios das capitanias que não haviam sido assoladas pela seca. Em 25 de janeiro de 1792, o senado da Câmara do Recife escreveu ao governador Tomás José de Melo para que desse "sábias providências para que se aumente a concorrência deste gênero, vindo de fora pela falta que há no interior do País", lugares onde só a autoridade do governador chegaria ${ }^{385}$. Em resposta, José de Melo solicitava aos vereadores que "vendo algum negociante que tenha barcos e posses para mandar vir de outras capitanias" assim solicitasse, que de sua parte estava "pronto para lhes dar ofícios que forem precisos para os governadores e capitães gerais deles não embaraçassem a entrada deste gênero para o socorro dos povos desta capitania" ${ }^{386}$.

Poucos meses depois, em março de 1792, o Governador Geral de Pernambuco escrevia a José de Portugal, Governador da Bahia, a respeito do

estado a que se acha reduzida esta capitania com a falta de farinha de pao, que nela se experimenta, por causa da grande seca que houve no ano de 1791, e ainda continua com tanto excesso que as poucas covas que naquele ano escaparão a esterilidade do tempo presentemente se vão reduzindo pó por não ter ainda chovido; vindo desta sorte a aumentar-se mais a miséria e fome, e se

\footnotetext{
${ }^{381}$ APEJE - Registro de Provisões, Portarias, Editais e Bandos , 4/2, fl. 73. Olinda, 23 de janeiro de 1792. Portaria para entregar uma pouca da farinha vindo do Porto Real para se repartir ao Povo.

382 APEJE - Registro de Provisões, Portarias, Editais e Bandos , 4/2 fls. 77v - 78. Olinda, 23 de janeiro de 1792. Portaria para entregar uma pouca da farinha vindo do Porto Real para se repartir ao Povo.

383 IAHGP - LRCMR (1733-1808), fl. 71. Recife, 24 de fevereiro de 1792. Carta da Câmara do Recife ao governador de Pernambuco.

${ }^{384}$ IAHGP - LRCMR (1733-1808) , fl. 71. Recife, 24 de fevereiro de 1792. Carta da Câmara do Recife ao governador de Pernambuco.

${ }^{385}$ IAHGP - LRCMR (1733-1808), fl. 68. Recife, 21 de janeiro de 1792. Carta da Câmara do Recife ao governador de Pernambuco.

${ }^{386}$ IAHGP - LRCMR (1733-1808), fl. 69 v. Recife, 21 de janeiro de 1792. Carta do governador de Pernambuco à Câmara do Recife.
} 
esta capitania não for socorrida de fora certamente perecerá o Povo dela a necessidade ${ }^{387}$.

Diante da situação, Tomás José de Mello solicitou a José de Portugal, que autorizasse carregar farinha com brevidade nos barcos Nossa Senhora do Monte do Carmo e Senhor Bom Jesus que se encontravam no Porto da Cidade de Salvador, "levando dinheiro aprontado pela Câmara" para o pagamento das cargas. Solicitava também que o mesmo tratamento tivesse outros barcos que ali aportassem com o mesmo destino, fazendo-se "embarcar neles aquelas quantidades que julgar não farão falta aos Povos" daquele governo ${ }^{388}$. Cerca de três meses após o supracitado pedido feito por Tomás José de Mello, o Governador da Bahia escrevia ao ministro da Marinha e Ultramar, Martinho de Melo e Castro, sobre as contínuas remessas de mantimentos que fazia para Pernambuco, "não só concedendo licença a várias embarcações para carregarem este gênero tão necessário, mas até não procedendo contra aquelas pessoas que embarcam bastante porção" ${ }^{389}$.

Além da grande demanda por gêneros da capitania de Pernambuco e anexas em decorrência da seca, a Bahia também recebia pedidos de socorro vindos do outro lado do Atlântico. Graças às teleconexões do El Niño de forte intensidade que aconteceu entre 1791 e 1792, Angola também foi afligida por uma rigorosa seca. Segundo Miller, a duradoura falta de chuvas teria destruído boa parte das lavouras de alimentos, provocando uma crise de abastecimento, levando ao deslocamento em massa de pessoas do interior para os centros urbanos $^{390}$. Diante dessa situação, o Governador de Angola buscou regular a oferta de alimentos através da importação de gêneros da Bahia, "persuadido de que este pais (Angola), no estado em que se acha de esterilidade por falta de chuvas, não pode de forma alguma fornecer os mantimentos precisos para os seus habitantes, comercio e continuadas expedições" ${ }^{391}$. Para

\footnotetext{
${ }^{387}$ BNRJ - II - 32, 33, 17. Recife, 26 de março de 1792. Ofício do Governador de Pernambuco ao Governador da Bahia.

${ }^{388}$ BNRJ - II - 32, 33, 17. Recife, 26 de março de 1792. Ofício do Governador de Pernambuco ao Governador da Bahia.

${ }^{389}$ AHU - Bahia (Eduardo de Castro e Almeida), D, 14901. Bahia, 9 de julho de 1792 Oficio do Governador D. Fernando José de Portugal para Martinho de Mello e Castro, no qual se refere à falta de farinha de pao na Capitania de Pernambuco e no Reino de Angola, por causa da seca extraordinária que tinham sofrido, e as providências que tomara para os socorrer.

${ }^{390}$ MILLER, Joseph. The significance of drought, disease and famine in the agriculturally marginal zones of WestCentral Africa. The Journal of African History, vol. 23, n. 1, jan. 1982, p. 52-55.

${ }^{391}$ AHU - Bahia (Eduardo de Castro e Almeida), D, 14901. Bahia, 9 de julho de 1792 Oficio do Governador D. Fernando José de Portugal para Martinho de Mello e Castro, no qual se refere à falta de farinha de pao na Capitania de Pernambuco e no Reino de Angola, por causa da seca extraordinária que tinham sofrido, e as providências que tomara para os socorrer.
} 
remediar a necessidade da população, o Governador enviava embarcações para serem carregadas com farinha, compradas por 2.000 reis o alqueire.

Paralelamente, a seca e a crise de abastecimento continuavam a afligir Pernambuco e anexas, e perante a "eminente ruína e as funestas consequências que se podem seguir de um povo falto inteiramente do gênero da primeira necessidade", Tomás José de Mello continuava a enviar pedidos de socorro para a Bahia. Diante das novas solicitações, o Governador da Bahia informava que não poderia mais remeter cargas abundantes de mantimentos, já que a "grande porção deste gênero que é levado para Pernambuco e Angola", que padecia de "igual calamidade, procedida da mesma causa" o estava fazendo "tomar algumas cautelas e medidas sobre este mantimento da primeira necessidade" ${ }^{392}$. O temor do Governador era de que a constante saída de gêneros da capitania levasse a Bahia a também sofrer com uma crise de abastecimento.

Ao longo da década de 1790 os pedidos de "socorro" através do envio de grandes volumes de farinha e demais gêneros de primeira necessidade também foram constantes para as capitanias do Rio de Janeiro. Em Junho de 1792, o Governador de Pernambuco, Tomás José de Mello, solicitou diante do "miserável estado a que se acha reduzida aquela capitania com a falta de farinha de pao pela grande seca" que o Vice-rei do Estado do Brasil, deixasse embarcar nos barcos enviados "quantidade que julgasse não fariam falta aos povos desta Capital”. A respeito das solicitações, o Vice-rei, Conde de Resende, informava que:

logo que recebi o aviso acima referido fiz imediatamente sair o dito barco. [...] Depois de expedida a referida embarcação entrarão outras neste porto com o mesmo destino as quais permiti a licença para comprarem esta qualidade de mantimento ${ }^{393}$.

Segundo o Conde de Resende, diante do lastimável estado apresentados por Tomás José de Mello, ele jamais poderia "abandonar uma capitania de Sua Majestade, podendo e devendo socorrê-la". Entretanto, apesar da resposta afirmativa do vice-rei à solicitação do Governador de Pernambuco, a Câmara do Rio de Janeiro ordenou aos almotaces "fazerem prender os

\footnotetext{
${ }^{392}$ AHU - Bahia (Eduardo de Castro e Almeida), D, 14901. Bahia, 9 de julho de 1792 Oficio do Governador D. Fernando José de Portugal para Martinho de Mello e Castro, no qual se refere à falta de farinha de pao na Capitania de Pernambuco e no Reino de Angola, por causa da seca extraordinária que tinham sofrido, e as providências que tomara para os socorrer.

${ }^{393}$ AHU- Avulsos do Rio de Janeiro, D. 11246. Rio de Janeiro, 22 de junho de 1792. Ofício do Vice-rei do Estado do Brasil, Conde Resende, ao secretário de estado da marinha e ultramar Martinho de Melo e Castro, sobre a ajuda solicitada pelo governador de Pernambuco para que fosse remetida àquela Capitania farinha de mandioca; e a tentativa da Câmara do Rio de Janeiro de tentar impedir a referida remessa.
} 
mestres das embarcações referidas e desembarcar a sua carga" 394 . A negativa dada pelo senado da Câmara às solicitações pernambucanas pode ser um indício do temor de que a demanda externa de gêneros de primeira necessidade colocasse em risco o abastecimento local, desviando da população os alimentos necessários para o seu aprovisionamento.

Em edital de 01 de agosto de 1792 o Governador de Pernambuco apontou que "apesar das providências com que por tantos modos tenho procurado abundar de farinha e mantimentos desta vila na presente esterilidade", a taxação sobre o gênero não tornava a venda atraente para os comerciantes que saíam de outras regiões ${ }^{395}$. Dessa forma, como providência para atrair o interesse de comerciantes de outras regiões e "abundar de farinha e mantimentos a vila", Tomás José de Melo, mandou revogar o tabelamento dos preços da farinha que vinha de outras capitanias. Segundo o Governador, "da mesma liberdade que faculta a farinha devem ficar também gozando todos os mais gêneros, como sejam milhos, feijão, arroz, que das ditas capitania se conduziam para esta Vila para se venderem ao Povo dela". A venda, por sua vez, poderia ser realizada nos próprios barcos, desde que feita "publicamente ao povo no ancoradouro da Praia do Colégio", como forma de evitar a ação de atravessadores, e "sem que na sua venda se intrometam os almotacés". A liberdade de preços determinada pelo Governo não deveria ser aplicada para as farinhas produzidas em Pernambuco e Anexas, que continuavam com o seu preço tabelado em 1280 reis o alqueire ${ }^{396}$.

A liberdade dos preços dos gêneros vindos de outras capitanias teria atraído inúmeros comerciantes que ansiavam lucrar com a penúria e carestia que se experimentava na Capitania Geral de Pernambuco. Um reflexo interessante desse momento foi percebido em São Paulo, onde um almotacé registrou em termo de vereança, no ano de 1793, um discurso sobre os problemas motivados pelos comerciantes que "movidos de ambição, estavam aproveitando a carestia em Pernambuco, Angola e Benguela para aumentarem os seus interesses, atravessando

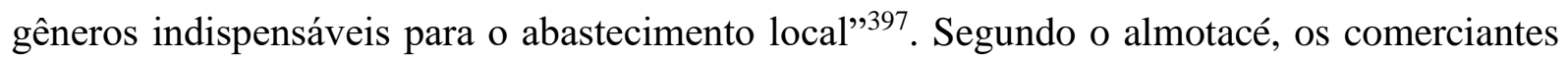
escoavam pelos portos da capitania “toda farinha, feijão e arroz que lhes foi possível”, não só

\footnotetext{
${ }^{394}$ AHU- Avulsos do Rio de Janeiro, D. 11246. Rio de Janeiro, 22 de junho de 1792. Ofício do Vice-rei do Estado do Brasil, Conde Resende, ao secretário de estado da marinha e ultramar Martinho de Melo e Castro, sobre a ajuda solicitada pelo governador de Pernambuco para que fosse remetida àquela Capitania farinha de mandioca; e a tentativa da Câmara do Rio de Janeiro de tentar impedir a referida remessa.

395 APEJE - Registro de Provisões, Portarias, Editais e Bandos , 4/2, fl. 89v Recife, 01 de agosto de 1792. Edital sobre levantar a taxa de farinha vinda de outras capitanias.

396 APEJE - Registro de Provisões, Portarias, Editais e Bandos , 4/2, fl. 89v Recife, 01 de agosto de 1792. Edital sobre levantar a taxa de farinha vinda de outras capitanias.

397 CÂMARA, Leandro Calbente. Administração colonial e poder: a governança da cidade de São Paulo (17651802). Dissertação de mestrado. São Paulo: USP/FFLCH/PPGHE, 208, p. 127 - 128.
} 
de São Paulo, mas de Nazaré, Atibaia e Jaguari. Com isso, os preços teriam mais que dobrado, fazendo o povo experimentar a carestia e a falta ${ }^{398}$.

No Rio de Janeiro, as providências tomadas pelas autoridades não foram suficientes para conter o escoamento de alimentos do mercado local para a Capitania Geral de Pernambuco e Angola. Em dezembro de 1792, o Juiz de Fora, Baltazar da Silva Lisboa, procedeu a uma devassa sobre os constantes contrabandos de farinha feitos para fora da capitania, em especial sobre as "negociações fraudulentas para Pernambuco com detrimento dos povos" 399 . Segundo rol de testemunhas, existiam "muitos atravessadores de mantimentos, mas comerciantes e lavradores também embarcavam mantimentos para fora”, tudo orquestrado pelo atravessador Francisco Pinheiro, com a ajuda de João de Figueiredo, então Provedor da Fazenda Real. Segundo informações contidas na devassa, Figueiredo recolhia uma parte dos gêneros enviados pelos produtores para o Armazém Real e encaminhava a outra parte para embarcações que seguiam ilegalmente para Pernambuco e para Angola. Numa dessas situações, a testemunha Antônio Alves, que vivia “de seu armazém de mantimentos", contou que teria tido vinte e cinco sacos de farinhas tomados pelo Provedor da Fazenda. Depois disso, o Provedor teria mandado “colocar os referidos gêneros a bordo de um navio de Francisco Pinheiro Guimarães", conhecido atravessador ${ }^{400}$. Diante das averiguações, o Juiz de Fora escreveu ao Secretário de Estado da Marinha informando sobre:

a saída e travessia de mantimentos que tem havido nesta Cidade, e que fizeram o objeto da devassa a que procedi em conformidade da lei e nela depuseram as testemunhas haver travessias de mantimentos; denunciarão ao Provedor da Fazenda Real e ao Ajudante de Ordens Gaspar José de Matos, a pouco que declararam unidos com os exames e averiguações, a que mandei proceder pelos Almotaceis a bordo das embarcações faziam alguma prova de culpa contra os mesmos, que protegiam as travessias para Pernambuco e outras partes $^{401}$

Segundo o Juiz de Fora, Baltazar da Silva Lisboa, as autoridades envolvidas na travessia tentaram justificar que a baixa oferta de alimentos era consequência de uma seca que atingia as

\footnotetext{
${ }^{398}$ CÂMARA, Leandro Calbente. Administração colonial e poder...op. cit, p. 127 -128.

${ }^{399}$ AHU - Rio de Janeiro D, 11332. Rio de Janeiro, 22 de dezembro de 1792. Ofício do juiz de Fora do Rio de Janeiro, Baltazar da Silva Lisboa, ao Secretário de Estado da Marinha e Ultramar, Martinho de Melo e Castro, sobre a devassa que procedeu contra o contrabando de farinha de mandioca e outros mantimentos exportado por negociação fraudulenta para Pernambuco com detrimento dos povos.

${ }^{400}$ AHU - Rio de Janeiro D, 11332. Rio de Janeiro, 22 de dezembro de 1792. Ofício do juiz de Fora do Rio de Janeiro, Baltazar da Silva Lisboa, ao Secretário de Estado da Marinha e Ultramar, Martinho de Melo e Castro, sobre a devassa que procedeu contra o contrabando de farinha de mandioca e outros mantimentos exportado por negociação fraudulenta para Pernambuco com detrimento dos povos.

${ }^{401}$ AHU - Rio de Janeiro D, 11355. Rio de Janeiro, 8 de março de 1793. Oficio do Juiz de Fora do Rio de Janeiro, Baltazar da Silva Lisboa, ao Secretário de estado da Marinha e Ultramar, Martinho de Melo e Castro, informando o contrabando dos mantimentos que foram objeto da devassa que implica o procurador da Fazenda, João de Figueiredo, o ajudante de ordens Gaspar José de Matos e diversos militares.
} 
lavouras do Rio de Janeiro. Entretanto, Silva Lisboa constou "não haver a esterilidade suposta" e que, na realidade, "estavam os lavradores desmanchando as mandiocas intempestivamente para conseguirem o alto preço da farinha ${ }^{402}$ ". Diante da constante exportação de alimentos, em dezembro de 1792, o preço da farinha no Rio de Janeiro já era fixado em 1.280 reis o alqueire, quando antes "o seu preço regular era de oito a nove tostões", cerca de 640 reis. O novo preço era o mesmo estipulado pelas autoridades da Capitania Geral de Pernambuco, demonstrando a influência que o surgimento de um mercado mais lucrativo em outra região poderia ter sobre o abastecimento local.

Esse envio regular de alimentos para outras regiões fez surgir a penúria e a carestia, despontando uma crise de subsistência, e em princípios de 1793 a sede do Vice-rei já era palco de agitações causadas pela elevação do preço da farinha. A este respeito, a repartição do gênero feita pelos militares teria resultado em "clamores e tumultos populares no Largo do Palácio", uma vez que o "pao da terra" já era vendido a 1.920 reis o alqueire. Segundo o Vice-rei, a "grande precisão que se experimentou nesta cidade do provimento de farinha de mandioca", se deu em decorrência das regulares remessas feitas "às capitanias de Pernambuco e ao Reino de Angola, que sentindo uma falta geral de mantimentos, têm recorrido a esta capitania"403.

As consequências da seca que assolou a Capitania Geral de Pernambuco ultrapassaram, assim, a sua própria fronteira. A seca e a penúria consequente da destruição das lavouras elevavam os preços dos alimentos nas capitanias do norte, fazendo das mesmas um mercado atraente para produtores e comerciantes de outras regiões, que passavam, então, a retirar boa parte dos seus produtos do mercado local e enviá-los para o mercado mais lucrativo. Assim, no Rio de Janeiro, na Bahia e em São Paulo, os anos iniciais da década de 1790 teriam sido marcados por um forte impacto das necessidades externas de alimentos sobre a economia local. Esse movimento teria provocado uma elevação geral nos preços dos alimentos, que passaram a ser tabelados de acordo com os valores alcançados em Pernambuco e Anexas, levando a uma sincronia dos preços dos mantimentos, em especial da farinha de mandioca, na colônia.

\footnotetext{
${ }^{402}$ AHU - Rio de Janeiro D, 11355. Rio de Janeiro, 8 de março de 1793. Oficio do Juiz de Fora do Rio de Janeiro, Baltazar da Silva Lisboa, ao Secretário de estado da Marinha e Ultramar, Martinho de Melo e Castro, informando o contrabando dos mantimentos que foram objeto da devassa que implica o procurador da Fazenda, João de Figueiredo, o ajudante de ordens Gaspar José de Matos e diversos militares.

${ }^{403}$ AHU - Rio de Janeiro D, 11355. Rio de Janeiro, 8 de março de 1793. Oficio do Juiz de Fora do Rio de Janeiro, Baltazar da Silva Lisboa, ao Secretário de estado da Marinha e Ultramar, Martinho de Melo e Castro, informando o contrabando dos mantimentos que foram objeto da devassa que implica o procurador da Fazenda, João de Figueiredo, o ajudante de ordens Gaspar José de Matos e diversos militares
} 


\section{Seca e pecuária}

Além de aniquilar parte das lavouras de alimentos, a falta de chuvas causava a destruição dos pastos nos sertões e o esgotamento das reservas de água necessárias ao abastecimento das criações, causando sérios problemas para o desenvolvimento da pecuária. Apesar da adaptabilidade e resistência do gado ao ambiente sertanejo e à estação seca anual, quando a falta de chuvas se prolongava por meses ou anos a fio e atingia os recursos das serras úmidas e rios mais caudalosos, refúgio do gado durante a estação seca, as chances de sobrevivência das criações ficava bastante reduzida. Dessa forma, a longa seca de três anos teria impactado significativamente sobre a criação de gado nos sertões da Capitania Geral de Pernambuco.

A grande destruição que a "grande seca" deixou nos pastos ficou marcada na memória popular sertaneja. No último quartel do século XIX, durante a seca de 1877, o Senador Pompeu relembrou a devastação da "seca tão terrível e rigorosa" principiada em 1791, que em "1792 tornou-se tão excessiva, que assolou, destruiu e matou quase todos os gados dos sertões e por isso veio a desaparecer o comércio das carnes-secas, e já não houve gado para o consumo"404. Possíveis exageros à parte, a narrativa pontua um cenário de devastação, mostrando o forte impacto que a seca teria tido para a pecuária nos sertões das capitanias do norte oriental da América portuguesa. Segundo Pompeu, a situação nos sertões complicou-se quando, finda a estação seca, não chegou a "estação invernosa", e a partir daí seguiu-se

o perecimento de toda a cultura, à exceção de alguns poucos brejos das serras, e morrinha dos gados no sertão, não tanto por falta de água, porque esta sempre se encontra, cavando-se o leito dos rios, mas de forragem, porque a pastagem do ano anterior tem desaparecido completamente, e a nova não nasceu, ou não pode vingar ${ }^{405}$.

Em janeiro de 1793, o Senado da Câmara de Montemor-o-Novo, no Ceará, escrevia à Rainha que "a mais vigorosa e longa seca que experimentamos teve princípio no ano de 1791", e seus "efeitos imediatos foram o faltar o pasto e a água para o sustento dos animais" 406 . Diante da falta de chuvas, "seguiu-se uma geral mortandade de gado vacum e cavalar nas fazendas desta capitania que tratam da multiplicação destas espécies e os criadores e mais vizinhos

\footnotetext{
${ }^{404}$ SOUZA. Thomaz Pompeu de. O Clima e as Secas do Ceará. Rio de Janeiro: Tipografia Nacional, 1877, p. 24 405 Idem.

${ }^{406}$ AHU - Avulsos (BG), D. 2345. Lisboa , 25 de janeiro de 1793. Consulta do Conselho Ultramarino à rainha (D. Maria) sobre a carta do juiz e mais oficiais da Câmara da Vila de Montemor-o-novo, da capitania de Pernambuco acerca do estado miserável que se acham reduzidos os moradores daquele continente, por causa da seca que assola a região desde 1791, os sucessivos roubos dos malfeitores e as execuções que fazem os credores
} 
tiveram a precisão de se abandonarem a uma peregrinação deixando os seus domicílios" 407 . À procura de água, as boiadas chegavam a ser deslocadas por até 20 léguas, excetuando-se “aqueles bois que por sua magreza não podem caminhar e morrem" ${ }^{408}$. A respeito da morte dos rebanhos no auge da seca, os arrematantes dos Dízimos dos Sertões escreviam naquele momento que "o criador que apanhava mil bezerros será contente chovendo em outubro e janeiro se apanhar cem, porque se não chover nesses meses não apanhará dez" ${ }^{409}$. Diante do contínuo esgotamento dos recursos hídricos, como os gados consumiam um grande volume de água, muitos criadores se viam obrigados, inclusive, a liquidar o que restava dos rebanhos, para evitar uma perda total.

Além de provocar a morte de parte do gado no sertão, "a seca geral dificulta a condução do resto por dilatados e estéreis caminhos" ${ }^{410}$. A longa estiagem também se tornava um empecilho ao transporte das criações, uma vez que, em decorrência da falta de pastos e recursos hídricos, uma parcela do rebanho era incapaz de sobreviver à longa travessia feita até as feiras. Muitos criadores terminavam a extensa caminhada com poucas rezes para venda, e a baixa oferta era rapidamente sentida no mercado de abastecimento. Em meados de 1792, os camarários de Igarassu já se queixavam de "especialmente no último ano ter faltado diversas vezes carne fresca no açougue", segundo os edis, o principal motivo do mau abastecimento seria "a seca e a carestia dos gados dela proveniente". Apesar disso, o Senado da Câmara acreditava que "se nos anos seguintes se restituírem os sertões o seu antigo estado, estamos persuadidos que não faltará carne fresca ${ }^{411}$ ”.

O abastecimento de carnes frescas para a população era realizado nos açougues públicos, imóveis onde existiam vários talhos, um ao lado do outro, e nos talhos dispersos,

\footnotetext{
${ }^{407}$ AHU - Avulsos (BG), D. 2345. Lisboa , 25 de janeiro de 1793. Consulta do Conselho Ultramarino à rainha (D. Maria) sobre a carta do juiz e mais oficiais da Câmara da Vila de Montemor-o-novo, da capitania de Pernambuco acerca do estado miserável que se acham reduzidos os moradores daquele continente, por causa da seca que assola a região desde 1791, os sucessivos roubos dos malfeitores e as execuções que fazem os credores.

${ }^{408}$ PAULET, Antônio José da Silva. Descripção Geográfica Abreviada da Capitania do Ceará. RIHGB, v.96, pt. 2, 1897. Rio de Janeiro: IHGB, 1897, p. 15.

409 AHU - Pernambuco, D. 12942. Lisboa, 30 de setembro de 1794. Relação feita pelo secretário do Conselho Ultramarino, Francisco de Borja, dos papéis da capitania de Pernambuco que baixaram com o aviso nesta Secretaria, referindo-se a contas da Junta da Fazenda Real, informações do contador geral e da câmara de Igarassu, sobre o contrato do subsídio das carnes.

410 AHU - Pernambuco, D. 12942. Lisboa, 30 de setembro de 1794. Relação feita pelo secretário do Conselho Ultramarino, Francisco de Borja, dos papéis da capitania de Pernambuco que baixaram com o aviso nesta Secretaria, referindo-se a contas da Junta da Fazenda Real, informações do contador geral e da câmara de Igarassu, sobre o contrato do subsídio das carnes.

411 AHU - Pernambuco, D. 12942. Lisboa, 30 de setembro de 1794. Relação feita pelo secretário do Conselho Ultramarino, Francisco de Borja, dos papéis da capitania de Pernambuco que baixaram com o aviso nesta Secretaria, referindo-se a contas da Junta da Fazenda Real, informações do contador geral e da câmara de Igarassu, sobre o contrato do subsídio das carnes.
} 
localizados nas diversas ruas das vilas e freguesias, onde vendiam-se os "miúdos das rezes que se matam nos açougues" ${ }^{\prime 12}$. As licenças para comercializar o gênero em questão deveriam ser obtidas por meio de editais de arrematação, assim, "a Câmara executora do monopólio da distribuição e venda da carne, passava, por hasta pública, este direito às mãos de um determinado número de comerciantes, denominados marchantes" ${ }^{" 413}$. Os editais de arrematação praticados pelas Câmaras eram lançados buscando suprir as necessidades cotidianas dos centros urbanos, assim, por meio de leilão ficava decidido quem iria operar o serviço arrematado, sob as penas da lei caso as obrigações não fossem cumpridas. Aos marchantes, então, cabia comprar o gado para vendê-lo abatido nos açougues, comprometendo-se a não deixar faltar a carne e assegurar a limpeza dos talhos e matadouros ${ }^{414}$. Entretanto, em tempos de rigorosa seca, a devastação dos rebanhos nos sertões, dificultava a tarefa dos marchantes e o provimento dos açougues tornava-se bastante problemático.

Garantir a chegada constante de carne fresca, com preços dentro dos padrões do mercado durante a intempérie demandava um constante esforço e vigilância das municipalidades. Em vereação de janeiro de 1791, quando a seca principiava a se alastrar pelos pastos sertanejos, o Senado da Câmara do Recife deliberava sobre "prorrogar os editais que tinham posto a respeito da rematação das carnes, por não "haver quem lançasse nem rematasse a dita marchantaria" 415 . Diante da continuada falta de lances, em outubro do mesmo ano a municipalidade voltava a deliberar sobre a arrematação da matança do gado, onde determinou-se que o "porteiro metesse em praça pregão de venda e arrematação talhos de carne de vaca", fazendo saber a "todos os marchantes que for que quererem contratar-se sobre as ditas marchantarias que a todo tempo se poderão fazer" ${ }^{\prime 16}$. Apesar da diligência dos camarários, o fim do ano chegou sem que ninguém se obrigasse a fornecer carne aos açougues. Frente à situação, o senado da Câmara procurou estabelecer algumas medidas para garantir uma maior oferta de carne. Além de prorrogar mais uma vez os editais de arrematação, determinou-se "poder matar as rezes toda a pessoa livremente, [...] sem que possa vender-se fora do dito açougue, pelo preço que bem parecer a esta câmara segundo necessidade e esterilidade do ano", estabelecendo duras penas contra os

\footnotetext{
412 SOUSA. Avanete Pereira. Poder local e cotidiano: a Câmara de Salvador no século XVIII. VIOTTI, Ana Carolina. As práticas e os saberes médicos no Brasil Colonial (1677-1808). Dissertação de Mestrado. Salvador: UFBA/ FFCH/ PPGH, 1996, p. 149

${ }^{413}$ Idem.

414 TAVARES, Georgia da Costa. A atuação dos marchantes no Rio de Janeiro colonial. Estratégias de mercado e redes de sociabilidade no comércio de abastecimento de carne verde (1763-1808). Rio de Janeiro: Arquivo Geral da Cidade do Rio de Janeiro, 2012, p. 41.

${ }^{415}$ IAHGP - Livro de Registro da Câmara Municipal do Recife ( 1784 - 1806).

${ }^{416}$ IAHGP - Livro de Registro da Câmara Municipal do Recife ( 1784 - 1806).
} 
atravessadores. Ademais, se estabeleceu "ficar livre aos senhores de engenho poderem matar livremente para gastos de sua fábrica do seu engenho e igualmente aos seus lavradores, pagando os impostos e direitos reais da carne de costume"417.

Concomitantemente, a Câmara de Igarassu relatava à Junta da Fazenda Real as dificuldades encontradas para realizar o abastecimento de carne na Vila, alegando que apesar de ter procedido a novos editais de arrematação ao longo de meses,

não acudiu lançador algum; por que já experimentava falta de gados e se temia maior, tendo presente a seca que grassava por este País, que com efeito continuou; e em tal figura ninguém por mais opulento que fosse, se proporia a obrigar-se a fornecer de carne os açougues enquanto não mudasse de face aquela triste situação. ${ }^{418}$

A falta de carne e as dificuldades encontradas para se proceder ao seu abastecimento apareceram com grande frequência nas vereações e correspondências trocadas pelas Câmaras da Capitania Geral de Pernambuco durante a longa estiagem. Isso acontecia uma vez que, ao dizimar um grande número de criações no sertão, a seca reduzia a sua oferta e provocava uma elevação nos seus preços, dificultando a compra de bois pelos marchantes, o que, consequentemente, impunha obstáculos à distribuição de carne nos açougues para a população.

Em face ao quadro exposto pelas municipalidades, em abril de 1792, a Junta da Fazenda Real escrevia ao Governador Geral de Pernambuco sobre "a grande seca de que falam as Câmaras, e que vem devastando, e vai devastando atualmente as fazendas de gados desta capitania, Paraíba, Rio Grande e Ceará" ${ }^{419}$. Conforme a Junta, a calamidade estava impossibilitando que os talhos fossem arrematados, uma vez que para abastecer os açougues seria preciso "mandar vir gados dos remotos sertões, ou comprá-los por altos preços a quem os foi lá buscar". Para garantir o abastecimento de carne, aconselhava-se, então, que o provimento dos açougues fosse realizado, quando possível fosse, "por conta da administração; por ter ela melhor que quaisquer particulares os meios de superar os referidos obstáculos", paralelamente, se deveria autorizar "que toda pessoa que quiser levar ao açougue as rezes que possa adquirir para esse fim" ${ }^{420}$.

\footnotetext{
${ }^{417}$ IAHGP - Livro de Registro da Câmara Municipal do Recife ( 1784 - 1806).

${ }^{418}$ AHU - Pernambuco, D. 12942. Lisboa, 30 de setembro de 1794. Relação feita pelo secretário do Conselho Ultramarino, Francisco de Borja, dos papéis da capitania de Pernambuco que baixaram com o aviso nesta Secretaria, referindo-se a contas da Junta da Fazenda Real, informações do contador geral e da câmara de Igarassu, sobre o contrato do subsídio das carnes.

419 AHU - Pernambuco, D. 12942. Lisboa, 30 de setembro de 1794. Relação feita pelo secretário do Conselho Ultramarino, Francisco de Borja, dos papéis da capitania de Pernambuco que baixaram com o aviso nesta Secretaria, referindo-se a contas da Junta da Fazenda Real, informações do contador geral e da câmara de Igarassu, sobre o contrato do subsídio das carnes.

${ }^{420}$ Idem.
} 
Além da redução da oferta do gado causada diretamente pela seca, havia quem visse na penúria de bois uma forma de auferir lucros maiores, dificultando ainda mais o acesso do povo à carne fresca. A este respeito, o Senado da Câmara de Igarassu apontava em carta escrita ao Governador em 1792 que a penúria dos gados seria "originada da seca geral, que ainda dura pelos sertões", mas também "do ambicioso projeto dos atravessadores, que compravam o gado assim na feira como nas estradas para revender e o revendiam por preços tão altos que vinham a ficar exorbitantes os dos talhos”421. Da mesma forma, a Contadoria Geral da Bahia advertiu ao Governo Geral de Pernambuco que a falta de interesse dos criadores em vender a carne diretamente aos açougues consistia "na maior rentalidade que experimentam vendendo os seus gados na feira e pelas estradas aos atravessadores que lhes compram para os revenderem por excessivos preços, donde provem a carestia”. Diante disso, a Contadoria aconselhava o Governo a

não permitir na Feira a compra de gados para serem revendidos; que se obriguem os criadores a marcharem os gados à feira, proibindo-se-lhes as vendas que não forem feitas ao marchantes ou aos lavradores que carecerem de gados para as suas fazendas, concedendo-se aos criadores o poderem cortar carne nos Açougues por sua conta, ajustando-se nos preços com as respectivas Câmaras ${ }^{422}$.

Em 1792, os oficiais da câmara do Recife escreveram ao Governador de Pernambuco expondo que, quando realizavam diligências sobre o aprovisionamento de carne fresca, seus almotacéis foram impedidos de atuar por homens armados. Diante disso, solicitavam que o Governador ordenasse "a todos os capitães mores e comandantes do sertão façam remeter a Feira de Goiana, sem opressão dos Povos, os gados possíveis”. A Câmara requisitou ainda que se tivesse atenção especial sobre o que se passava em Goiana, onde, segundo os edis, ocorriam irregularidades na lida com os rebanhos. Atendendo ao pedido dos camarários, o Governador determinou que os comandantes trabalhassem para que seus subordinados supervisionassem a condução do gado a Goiana, bem como o seu abate ${ }^{423}$. O Governador ainda autorizou que a

\footnotetext{
421 AHU - Pernambuco, D. 12942. Lisboa, 30 de setembro de 1794. Relação feita pelo secretário do Conselho Ultramarino, Francisco de Borja, dos papéis da capitania de Pernambuco que baixaram com o aviso nesta Secretaria, referindo-se a contas da Junta da Fazenda Real, informações do contador geral e da câmara de Igarassu, sobre o contrato do subsídio das carnes.

422 AHU - Pernambuco, D. 12942. Lisboa, 30 de setembro de 1794. Relação feita pelo secretário do Conselho Ultramarino, Francisco de Borja, dos papéis da capitania de Pernambuco que baixaram com o aviso nesta Secretaria, referindo-se a contas da Junta da Fazenda Real, informações do contador geral e da câmara de Igarassu, sobre o contrato do subsídio das carnes.

${ }^{423}$ IAHGP - Livro de Registro da Câmara Municipal do Recife, fl, 68. Recife, 25 de janeiro de 1792.Carta da Câmara Municipal do Recife ao governador D. Tomás José de Melo.
} 
câmara prendesse e sentenciasse quem descumprisse as normas impostas pela municipalidade ${ }^{424}$.

Diante da redução do rebanho e da dificuldade de regularizar o abastecimento de carne para a população, consequência da intempérie bem como da ação de indivíduos que realizavam transações ilegais, Pernambuco e anexas passaram a ser abastecidas pelos gados de outras capitanias. A este respeito, em 1792, a Contadoria Geral da Bahia aconselhou ao Governo Geral de Pernambuco que o restabelecimento das fazendas atingidas pela estiagem, que "se acham faltas de vacas, e bois para propagarem", fosse realizado por meio da "compra de gados do Piaui , onde a seca não fez estragos" ${ }^{\$ 25}$. Entretanto, como os criadores estavam carecidos de dinheiro, em decorrência das perdas causadas pela falta de chuvas, a Contadoria sugeria também que os mesmos fossem supridos pela Fazenda Real, que proporcionaria os valores das propriedades dos criadores, as quais serviriam de "hipotecas das dívidas, para pagamento das quais se poderá estabelecer o prazo de tempo que parecer justo". Mediante essa assistência, acreditava-se que teriam as "fazendas de gados um fácil restabelecimento e se evitaria maior falta de carne na capitania de Pernambuco e suas anexas" ${ }^{\text {426. }}$.

Tendo em vista o restabelecimento da oferta de gados, em carta escrita a Tomás José de Mello, Governador Geral de Pernambuco, a Junta da Fazenda Real, apontava que a restauração das fazendas e a regularização do abastecimento da carne nos açougues só poderia acontecer mediante a liberdade de venda dos bois. A Junta alegava "não ser possível que um gênero de primeira necessidade conserve igual preço no tempo da abundância, que no da esterilidade". Aconselhava-se, então, que as municipalidades estabelecessem um preço convidativo para que os marchantes fossem "buscar gados aos distantes e vastos sertões do Piauí e Maranhão, passado o inverno, único tempo em que os podem conduzir certos de que os lucros corresponderão aos trabalhos de uma tão distante jornada" ${ }^{227}$.

Apesar das providências tomadas para a reposição dos rebanhos da Capitania Geral de Pernambuco, a última década dos setecentos foi marcada pela penúria e carestia de bois. Em

\footnotetext{
${ }^{424}$ IAHGP - Livro de Registro da Câmara Municipal do Recife, fl, 68. Recife, 25 de janeiro de 1792.Carta da Câmara Municipal do Recife ao governador D. Tomás José de Melo.

425 AHU - Pernambuco, D. 12942. Lisboa, 30 de setembro de 1794. Relação feita pelo secretário do Conselho Ultramarino, Francisco de Borja, dos papéis da capitania de Pernambuco que baixaram com o aviso nesta Secretaria, referindo-se a contas da Junta da Fazenda Real, informações do contador geral e da câmara de Igarassu, sobre o contrato do subsídio das carnes.

426 AHU - Pernambuco, D. 12942. Lisboa, 30 de setembro de 1794. Relação feita pelo secretário do Conselho Ultramarino, Francisco de Borja, dos papéis da capitania de Pernambuco que baixaram com o aviso nesta Secretaria, referindo-se a contas da Junta da Fazenda Real, informações do contador geral e da câmara de Igarassu, sobre o contrato do subsídio das carnes.

${ }^{427}$ Idem.
} 
janeiro de 1799, negociantes e senhores de engenho de Pernambuco escreviam à Junta Governativa sobre as consequências da seca que havia "reduzido a áridos desertos todos os certões desta capitania, antes florescentes abundante de gado vacum, um dos principais recursos de particulares deste continente" ${ }^{428}$. Diante das perdas causadas pela intempérie, os habitantes da capitania ainda se viam "na urgente necessidade de irem com insano trabalho fadigas e despesas aos certões do Maranhão, Bahia e Minas para dali conduzirem os gados indispensáveis a vida" 429 .

Mesmo oito anos após o fim da calamidade, as autoridades pernambucanas ainda buscavam meios para abastecer a capitania de gados e garantir o aprovisionamento de carne fresca. Em maio de 1801 o Governo Interino de Pernambuco escrevia ao Governador do Piauí que "não estando ainda os sertões desta capitania abastecida de gados, depois do grande estrago da fatal seca", ainda se fazia necessário prover-se dos gados do sertão do Piauí "para a sustentação destes Povos, da Tropa, e das Fragatas e Navios de Guerra que frequentemente aqui chegam"430. O Governo pernambucano, então, informava sobre ter recebido queixas de que “alguns compradores desta dita capitania que tem ido aos daquela não tem sido aí bem tratados", e que algumas autoridades de freguesias do sertão estariam dificultando o envio de rezes para a capitania de Pernambuco. Considerando o exposto, solicitava-se que o Governador do Piauí providenciasse que nenhuma autoridade sob a sua jurisdição impedisse, "para a conservação e aumento da criação dos referidos gados naqueles Sertões", a exportação dos necessários bois.

Além de desregular o abastecimento de carne fresca em toda a Capitania Geral de Pernambuco, ao atingir os criatórios cearenses, em especial aqueles que se encontravam às margens do Jaguaribe e Acaraú, a longa estiagem também desorganizou as oficinas que se dedicavam a salga das carnes. Desenvolvida graças à demanda por um gênero alimentício que tivesse uma durabilidade maior, a carne seca podia ser transportada em viagens mais longas, evitando, assim, o prejuízo resultante das extensas travessias com o gado em pé. Ao longo do século XVIII, a escassez de carnes frescas, causada por intempéries que destruíam periodicamente os pastos dos sertões e dificultavam o suprimento nas vilas litorâneas, expandiu

\footnotetext{
${ }^{428}$ AHU - Pernambuco, D. 14497. Recife, 18 de janeiro de 1800. Oficio da Junta Governativa da capitania de Pernambuco ao secretario de estado da Marinha Ultramar Rodrigo de Sousa Coutinho, sobre aparecer a respeito da representação dos negociantes e proprietários de engenho sobre o pagamento do subsidio literário da carne seca 429 AHU - Pernambuco, D. 14497. Recife, 18 de janeiro de 1800. Oficio da Junta Governativa da capitania de Pernambuco ao secretario de estado da Marinha Ultramar Rodrigo de Sousa Coutinho, sobre aparecer a respeito da representação dos negociantes e proprietários de engenho sobre o pagamento do subsidio literário da carne seca. ${ }^{430}$ AL-017-002-09. E 30 de junho de 1801. OFÍCIO de D. Diogo de Sousa, governador do Maranhão, ao bispo de Pernambuco e governadores interinos, informando que recomendaria ao governador do Piauí que o auxiliasse, na medida do possível, na exportação de gado do Piauí para a capitania de Pernambuco.
} 
o mercado consumidor das carnes conservadas com sal. Entretanto, apesar de dispor de uma maior durabilidade e resistência frente às oscilações do clima que a carne fresca, durante a grande seca iniciada em 1791 a devastação dos rebanhos sertanejos impactou fortemente nas suas fábricas, em especial no Aracati, principal centro produtor de carne seca.

Em relato de 1795, Manoel Esteves D'almeida, vereador do Aracati, escreveu sobre os males causados pela estiagem "tão terrível e rigorosa que durou o espaço de 4 anos". Segundo o edil, a forte intempérie foi "excessiva de tal sorte que derrubou, destruiu e matou quase todos os gados dos sertões desta comarca", fazendo com que a vila viesse "a perder aquelle ramo de commercio das fábricas de carnes secas desde o anno de 1793 exclusivo, por que no anno de 1794 já não houve gados que se matar" ${ }^{\prime 31}$. Os dados dispostos no quadro abaixo, adaptado a partir de investigação realizada por Leonardo Rolim, corroboram com as informações fornecidas pelo vereador.

Tabela 4 - Entradas de sal e saída de carnes do Porto do Aracati (1767 - 1796)

\begin{tabular}{|c|c|c|}
\hline Ano & $\begin{array}{c}\text { Entradas de embarcações } \\
\text { com sal }\end{array}$ & $\begin{array}{c}\text { Saída de } \\
\text { embarcações com } \\
\text { carnes }\end{array}$ \\
\hline $\mathbf{1 7 6 7}$ & 3 & 4 \\
\hline $\mathbf{1 7 6 8}$ & 10 & 7 \\
\hline $\mathbf{1 7 6 9}$ & 3 & 3 \\
\hline $\mathbf{1 7 7 0}$ & 2 & 3 \\
\hline $\mathbf{1 7 7 1}$ & 1 & 1 \\
\hline $\mathbf{1 7 7 2}$ & 0 & 0 \\
\hline $\mathbf{1 7 7 3}$ & 10 & 12 \\
\hline $\mathbf{1 7 7 4}$ & 0 & 0 \\
\hline $\mathbf{1 7 7 5}$ & 4 & 8 \\
\hline $\mathbf{1 7 7 6}$ & 0 & 0 \\
\hline $\mathbf{I n t e r v a l o}$ & Intervalo & Intervalo \\
\hline $\mathbf{1 7 8 7}$ & 1 & 1 \\
\hline $\mathbf{1 7 8 8}$ & 2 & 6 \\
\hline $\mathbf{1 7 8 9}$ & 3 & 1 \\
\hline $\mathbf{1 7 9 0}$ & 2 & 7 \\
\hline $\mathbf{1 7 9 1}$ & 0 & 7 \\
\hline $\mathbf{1 7 9 2}$ & 0 & 6 \\
\hline $\mathbf{1 7 9 3}$ & 0 & 0 \\
\hline $\mathbf{1 7 9 4}$ & 0 & 0 \\
\hline $\mathbf{1 7 9 5}$ & 0 & 0 \\
\hline $\mathbf{1 7 9 6}$ & 0 & \\
\hline
\end{tabular}

${ }^{431}$ D’ALMEIDA, Manoel Esteves. Registro de Memória dos principaes estabelecimentos - factos e cazos raros accontecidos nesta villa da Santa Cruz do Aracaty, feita segundo a ordem de S.M., de 27 de julho de 1782 pelo vereador Manoel Esteves D’Almeida desde a fundação da ditta villa, até o anno prezente. In: Revista do Instituto do Ceará, Ano I, 1887. p. 80. 
Fonte: ROLIM, Leonardo Cândido. "Tempo das Carnes" no Siará Grande: dinâmica social, produção e comércio de carnes secas na Vila de Santa Cruz do Aracati (c. 1690 -c. 1802). Dissertação (Mestrado). UFPB, João Pessoa, 2012.

Segundo levantamento feito a partir dos registros de entrada e saída do Porto da Vila do Aracati, 20 barcos saíram carregados com carne seca durante os anos de estiagem. Dessa forma, apesar da devastação causada pela seca, pode-se entender que o gado disponível nos sertões foi matéria prima suficiente para cerca de três anos de produção. Sobre isso, não se pode descartar a possibilidade de que, durante a intempérie, a oferta de gados para as oficinas tenha sido oriunda da liquidação precoce e em massa dos rebanhos, empreendida por alguns criadores para evitar uma perda total diante da falta de recursos hídricos. A oferta de bois teria durado até meados de 1793, quando a última embarcação carregada de carnes secas saiu do Aracati, e no ano seguinte "já não houve gados para se matar" 432.

A interveniência da seca, quando eliminava provisória ou permanentemente várias unidades produtivas de uma região, terminava por favorecer outros núcleos produtores. A demanda causada pela escassez de carnes frescas nos açougues e pela paralização das oficinas de carnes secas no Ceará, terminou estimulando zonas de produção mais remotas da colônia, como a capitania de São Pedro do Rio Grande do Sul. Em meados de 1793, os camarários da Cidade da Paraíba escreviam à Junta da Fazenda que diante da "sucessiva seca e esterilidade de dois anos", que causava a falta de carne fresca nos açougues, estavam conseguindo remediar a fome da população graças às "carnes secas que lhes vem do sul"433. Semelhantemente, negociantes e senhores de engenho pernambucanos, informavam ao Governador que, em decorrência da "mais cruel e a mais datal das esterilidades procedida da espantosa e nunca vista seca de 3 anos", se viam na necessidade de ir buscar nas "mais remotas partes do Brasil a sustentação de sua escravatura [...]a um porto difícil e perigoso, qual é o do Rio Grande de São Pedro do Sul, para comprar as carnes beneficiadas por aqueles habitantes" ${ }^{\prime 34}$. A seca teve, assim, efeitos contraditórios, pois enquanto destruía rebanhos e desabastecia o povo de carnes,

\footnotetext{
432 D’ALMEIDA, Manoel Esteves. Registro de Memória dos principaes estabelecimentos - factos e cazos raros accontecidos nesta villa da Santa Cruz do Aracaty, feita segundo a ordem de S.M., de 27 de julho de 1782 pelo vereador Manoel Esteves D'Almeida desde a fundação da ditta villa, até o anno prezente. In: Revista do Instituto do Ceará, Ano I, 1887. p. 80.

433 AHU - Pernambuco, D. 12942. Lisboa, 30 de setembro de 1794. Relação feita pelo secretário do Conselho Ultramarino, Francisco de Borja, dos papéis da capitania de Pernambuco que baixaram com o aviso nesta Secretaria, referindo-se a contas da Junta da Fazenda Real, informações do contador geral e da câmara de Igarassu, sobre o contrato do subsídio das carnes.

434 AHU - Avulsos de Pernambuco. Recvife, 18 de janeiro de 1800, Janeiro, 18, recife. Oficio da Junta Governativa da capitania de Pernambuco ao secretario de estado da Marinha Ultramar Rodrigo de Sousa Coutinho, sobre aparecer a respeito da representação dos negociantes e proprietários de engenho sobre o pagamento do subsidio literário da carne seca.
} 
estimulava a produção e o crescimento das exportações do gênero no Rio Grande do Sul. Sobre isso, um relato feito pelos homens de negócios do Rio Grande é bastante elucidativo:

A esterilidade da capitania de Pernambuco seguida da fatal Revolução da Europa deu tal tom e valor aos principais efeito de primeira necessidade, quais o trigo e a carne, que dentro de cinco anos se viu transformar o Continente do estado de uma Colônia novamente criada e dependente de outras ao de uma antiga no comércio e providente de outras capitanias ${ }^{435}$.

Em seu estudo sobre a formação do Rio Grande do Sul, Maximiliano Menz relacionou a expansão inicial da economia da capitania, dentre outros motivos, à "esterilidade de Pernambuco". Segundo os dados levantados pelo autor, entre 1790 e 1795 teria se sucedido uma valorização considerável do charque gaúcho e junto com ela o crescimento da população cativa, indicando um comportamento geral de expansão na economia rio-grandense ${ }^{436}$. Entre os anos de 1792 e 1793, momento em que últimas remessas de carne seca saíam do Aracati, as exportações de charque do Rio Grande do Sul aumentaram em cerca de 27\%, com crescimento constante até $1807^{437}$. Sobre isso, os registros da Câmara do Recife apontam que entre o final do século XVIII e princípios do XIX aproximadamente 11 embarcações entraram anualmente no Porto do Recife, exclusivamente com cargas de carne seca oriundas do sul da América portuguesa $^{438}$.

Além de abastecer a Capitania Geral de Pernambuco com carnes, a produção gaúcha também passou a satisfazer as demandas das capitanias que, antes da famigerada seca, eram abastecidas pelas oficinas cearenses. Tal tendência pode ser muito bem observada em registro feito na Bahia por Luís dos Santos Vilhena, onde escreveu que: "era muito considerável o comércio que esta praça tinha com a capitania do Ceará em carnes salgadas, secas, [...] este porém se transferiu para o Rio Grande de São Pedro do Sul depois que as secas extremosas consumiram todos os gados naquelas paragens" ${ }^{\mathrm{4} 39}$.

Os impactos econômicos da desorganização do abastecimento local de carne desencadeada pela seca, bem como da consequente transferência da produção para centros produtores de outras regiões, também foram sentidos na arrecadação dos tributos relativos à

\footnotetext{
435 AHU - Avulsos do Rio Grande do Sul, D. 373. Porto Alegre, 24 de novembro de 1800. Ofício do Governador do Rio Grande de São Pedro, tenente-general Sebastião Xavier da Veiga Cabral da Câmara, ao secretário de estado da Marinha e Ultramar, D. Rodrigo de Sousa Coutinho, enviando requerimentos da corporação dos comerciantes e fazendeiros do Rio Grande de São Pedro.

436 MENZ, Maximiliano M. Entre dois impérios: Formação do Rio Grande na Crise do Antigo Sistema Colonial (1777 - 1822). Tese de Doutorado. São Paulo: FFLCH, 2006, p. 141.

${ }^{437}$ Ibidem, p. 141.

${ }^{438}$ IAHGP - Livro de Registro da Câmara Municipal do Recife (1802 - 1808), fl, 20. Recife, 25 de fevereiro de 1802. Registro de uma provisão da Junta da Real Fazenda da capitania de Pernambuco.

${ }^{439}$ VILHENA, Luís dos Santos. Recopilação de notícias soteropolitanas e brasílicas. Salvadoe, 1802, p. 338.
} 
pecuária na Capitania Geral de Pernambuco. As arrecadações mais afetadas foram o subsídio literário, aplicado sobre cada rês abatida com a finalidade de custear os mestres régios, e os dízimos das freguesias do sertão.

No ano de 1792, a Câmara de Natal entregou do subsídio literário "certidões em branco de não haver neste terceiro quartel literário rendimento" 440 , o mesmo ocorreu no ano seguinte, “por causa da seca não dar rendimento algum"441, e em 1794, "por não haver rendimento deste subsidio por causa da rigorosa seca que a pouco finalizou" ${ }^{\prime 42}$. Semelhante problema de arrecadação pode ser observado em Pernambuco, onde o subsídio também decresceu consideravelmente. Segundo o Deputado da Junta da Real Fazenda, Pedro Le Roy, a dificuldade encontrada para arrecadar o subsídio e para a falta de pagamento dos professores naquele momento "nasce da extraordinária seca que desde alguns anos se padece nestas capitanias e que abrasou fazendas de gado dos sertões [...]do que é evidente prova a notável falta de carne fresca que geralmente se experimenta" ${ }^{443}$. Perante a falta de carne, conforme já foi visto, os moradores supriam-se de carnes secas oriundas do Rio Grande do Sul, "sobre a qual não se podia aplicar o imposto, por ser, segundo a letra da lei, unicamente sobre a carne verde talhada nos açougues, vindo daí o decrescimento do subsídio e a falta de pagamento dos professores". Para remediar o problema da arrecadação, o Governo, então, determinou que as carnes salgadas oriundas do Rio Grande do Sul pagassem o mesmo imposto das carnes talhadas nos açougues ${ }^{444}$.

Em abril de 1793, o Provedor da Fazenda Real informava a respeito da falta de lances nos contratos dos Dízimos do Sertão da Paraíba para o triênio de 1793 a 1795, mesmo após andarem seis meses em praça pública. De acordo com o Provedor, a justificativa para a falta de lances nos contratos teria sido a "geral seca, e mortandade universal que houve nos sertões desta capitania em que pereceram quase todos os gados, desertaram e faleceram a maior parte dos habitantes dos sertões, ficando estes em uma total desolação" ${ }^{445}$. O arrendatário dos dízimos tinha uma estimativa da produção, e de aproximadamente quanto arrecadaria de dízimos a partir de informações sobre a produção da capitania. Entretanto, como a intempérie provocava a desorganização dos núcleos produtivos, a estimativa de arrecadação se tornava bastante incerta,

\footnotetext{
${ }^{440}$ IHGRN - Livro de Termos de Vereação do Senado da Câmara de Natal (1784 - 1803),fl. 199v.

${ }^{441}$ IHGRN - Livro de Termos de Vereação do Senado da Câmara de Natal (1784 - 1803), fl. 210v.

442 IHGRN - Livro de Termos de Vereação do Senado da Câmara de Natal (1784 - 1803), fl. 222.

${ }^{443}$ COSTA, Francisco Augusto Pereira. Anais Pernambucanos. v. 6. Recife: Secretaria do Interior e Justiça, 19511966, p. 339.

${ }^{444}$ Idem.

445 AHU - Paraíba. Paraíba, 25 de abril de 1793. Requerimento do sargento-mor Antônio Borges da Fonseca e do Sargento-mor Martias Fernandes de Sá, e outros, à Rainha, D. Maria I, em que solicitam, como arrematantes dos dizimos dos gados e minuncias das ribeira do Cariri de Fora, Piancó, Patu, Espinharas, Rio do Paixe e Sabugi, certidão da Provedoria da Fazenda de que não houve lance nos contratos para o triênio de 1793 - 1795.
} 
podendo facilmente gerar prejuízos para o contratante e, diante disso, era comum não haver nenhum lance.

Graças aos prejuízos causados aos rendimentos dos contratadores, durante a intempérie os pedidos de consignação de dívidas se tornaram comuns. Em agosto de 1794, os arrematantes do triênio de 1791 a 1794 dos dízimos de Aquiraz, Montemor-o-novo e Fortaleza, solicitavam prorrogação do tempo para o pagamento das dívidas relativas à arrematação. Segundo os suplicantes, os dízimos daquelas Freguesias eram resultantes da criação de gados, mas diante da seca

e nunca vista esterilidade que geralmente se experimentou e está experimentando naquele país e sertões não escapou das ditas Freguesias quase nada e algum pequeno resto muito limitado que tem escapado, ainda estão morrendo infectados e pestilentos e exposto aos inevitáveis furtos que continuamente estão fazendo dele. [...]E ainda que venha a cessar no ano próximo futuro a lamentável seca que está laborando, sempre durará nos primeiros futuros anos os seu funestos e tristíssimos efeitos ${ }^{446}$.

Argumentos semelhantes aos mencionados acima foram utilizados pelos arrematantes do triênio de 1791 a 1794 dos dízimos de Sobral, que em meados de 1794 solicitavam à rainha D. Maria I consignação favorável às suas dívidas. Os suplicantes alegavam que as riquezas daqueles sertões consistiam nos rebanhos, mas que a "seca tão rigorosa" levou à morte "gados grossos e miúdos, de sorte que os contratadores não tem uma cabeça de gado com que possam sanar as necessidades de suas famílias" 447 . No próprio requerimento foram arroladas outras pessoas como testemunhas, que reproduziram falas que reiteravam o estado de miséria imposto pela falta de chuvas.

Como foi possível observar, a seca que assolou a Capitania Geral de Pernambuco entre 1791 e 1793, destruiu colheitas e causou a morte de gados no sertão, desorganizando o sistema produtivo regional. Tal desorganização fez surgir a escassez e a carestia dos gêneros básicos à sobrevivência humana, levando a uma crise alimentar, com implicações socioeconômicas que extrapolaram as próprias fronteiras da capitania de Pernambuco e suas anexas. As

\footnotetext{
${ }^{446}$ AHU - Avulsos do Ceará, D. 696. Ceará, 23 de agosto de 1794. Requerimento do capitão Domingos Rodrigues da Cunha e seu sócio, Ignácio Barroso de Sousa, moradores da vila de Fortaleza e arrematantes dos dízimos reais da freguesia do Aquiraz, Montemor Novo e Fortaleza, à Rainha, D. Maria I, a pedir prorrogação do tempo para pagamento da dívida relativa a arrematação do referido contrato.

447 AHU - Ceará, D. 697. Ceará, 23 de agosto de 1794. Requerimento de Antônio Gomes Albuquerque e do sargento-mor Manuel Francisco de Vasconcelos, arrematantes do contrato dos dízimo reais da freguesia da Conceição da Nossa Senhora do Sobral, à rainha, D. Maria, a pedir consignação favorável às suas dividas, devido à seca de 1791-92, que ocasionou a morte do gado.
} 
consequências da longa estiagem foram profundas e duradouras, repercutindo até princípios do século XIX.

Quase dez anos após o fim da rigorosa seca, um govenador da capitania da Paraíba vendo o "miserável estado e total ruína a que ela vai caminhando", indagava-se a respeito da causa primeira da sua decadência. Chegou, então, a conclusão de que havia sido a "grande seca que houve em 1791, 92 e 93", por ter extinguido a maior parte das "forças que se encaminhavam para o seu aumento" ${ }^{448}$. Pouco tempo depois, em 1802, um semelhante flagelo já voltava açoitar a região.

448 AHU - Avulsos da Paraíba, D. 2801.Paraíba, 28 de fevereiro de 1803. Oficio do governador da Paraíba, Luis da Mota Fêo, ao secretário de estado da Marinha e Ultramar, Visconde de Anadia, informando do plano adotado para socorrer as necessidades públicas fome e carestia, em consequência das secas dos anos de 1791, 1792, 1793. 


\section{Considerações finais}

Ao longo da narrativa deste trabalho, já esclarecemos as principais conclusões tiradas sobre o nosso objeto de estudo. No entanto, a título de compilação e arremate iremos pontuar as considerações mais significativas para o entendimento da "grande seca" que se desenrolou entre os anos de 1791 e 1792 na capitania de Pernambuco e suas anexas.

O clima dos sertões do nordeste oriental sempre foi marcado pela contraposição entre a estação seca, que se encontrava presente na maior parte do ano, e alguns meses de chuva. Sob a influência da própria geografia local e de fenômenos climáticos exteriores, como o El Niño, em alguns anos podia acontecer de chover menos que o esperado durante o inverno, ou a estação de estio se prolongar, com secas que podiam durar anos. Da mesma forma, o inverno podia ser bastante rigoroso, com excessivas chuvas, causando cheias e danos à população. O clima das regiões interioranas de Pernambuco e anexas era, então, marcado pelos extremos.

A determinação de que a criação de gados só fosse permitida a, pelo menos, dez léguas do litoral, impeliu a pecuária para o sertão, e foi o impulso necessário para o estabelecimento concreto de contingentes populacionais nas regiões interioranas da capitania Geral de Pernambuco ao longo do século XVIII. A população foi se estabelecendo na região através das solicitações de sesmaria e datas de terras, usando como principal justificativa a utilização da terra para a criação de gados. Apesar da instabilidade do clima do sertão, os sertanejos encontraram alguns meios para lidar com as condições peculiares da sua geografia e garantir a ocupação produtiva da terra árida, como o desenvolvimento da agricultura de vazante e a construção de cacimbas. Essas estratégias eram capazes de assegurar recursos durante o período de seca anual, entretanto, quando a estiagem se prolongava, as reservas de água se esgotavam, dificultando o aproveitamento produtivo da terra.

Graças a facilidade do seu cultivo, a variedade do seu uso e a durabilidade da sua farinha, a mandioca e seus derivados configuraram-se como o gênero alimentar básico da capitania Geral de Pernambuco. Ao realizar o levantamento das vilas e freguesias que exportavam alimentos, percebemos que os maiores excedentes eram produzidos no litoral, cultivados principalmente por vilas de indígenas e agricultores livres. No sertão a agricultura de alimentos esteve condicionada aos empecilhos geográfico do semiárido, dessa forma, limitando-se às serras e brejos. A produção de alimentos em território sertanejo era, desta forma, limitada, tornando-se ainda mais problemática quando da ocorrência de uma seca. Ademais, ao longo do século XVIII, a agricultura de alimentos encontrou sérios entraves para o seu pleno funcionamento, como a baixa produção de alimentos no sertão, e a recusa da grande lavoura 
em produzir para o seu próprio abastecimento e fornecer excedentes para a população. Somando-se a esses fatores, as vantagens do cultivo do algodão, altamente demandado pelo mercado europeu, fez com que muitos tradicionais lavradores de alimentos passassem a se dedicar ao cultivo da fibra. Todos esses elementos fragilizavam o sistema alimentar, e foi essa fragilidade produtiva que permitiu que a seca desempenhasse um papel central no surgimento da crise.

A devastação de lavouras de alimentos causada pela seca de 1791 fez surgir a penúria e a carestia. Quando a seca alcançava sua máxima intensidade máxima, diante de reservas esgotadas e altos preços de alimentos, a alternativa para muitos sertanejos era seguir para as vilas litorâneas, que possuíam reservas maiores de alimentos. Essas pessoas tencionavam ainda mais o já problemático mercado de abastecimento, acarretando uma elevação ainda maior dos preços dos alimentos, aprofundando a crise nos centros urbanos. Visando sanar as consequências da crise, as autoridades coloniais empreenderam algumas medidas como: vigiar as roças, fintar produtores de farinha, proibir a saída de gêneros alimentícios para outras regiões e coibir a ação de atravessadores, endurecendo a fiscalização das vendas.

Apesar das determinações, as reservas locais continuaram insuficientes, e as autoridades passaram a solicitar o envio de alimentos das capitanias do Rio de Janeiro e da Bahia. Acontece que, simultaneamente, Angola também sofria com uma rigorosa seca e requeria envio de alimentos. Diante da situação, a necessidade de abastecer várias regiões fez com que no Rio de Janeiro, na Bahia e em São Paulo, os anos iniciais da década de 1790 fossem marcados por um forte impacto das necessidades externas de alimentos sobre a economia local. Esse movimento teria provocado uma elevação geral nos preços dos alimentos, que passaram a ser tabelados de acordo com os valores alcançados em Pernambuco e Anexas.

Para além dos gêneros agrícolas de primeira necessidade, os impactos da longa estiagem iniciada em 1791 também fizeram-se sentir nos rebanhos sertanejos, e a morte dos gados no sertão causou problemas para o abastecimento de carnes frescas nos açougues. Diante da geral mortandade, Pernambuco passou a depender da compra de reses do Piauí, onde a seca não teria feito estragos, até princípios do século seguinte. A devastação de rebanhos que desorganizou a produção de carnes secas no Ceará, entretanto, terminou por favorecer outros núcleos produtores, animando a produção de regiões mais remotas, como o Rio Grande do Sul. 


\section{Referências bibliográficas}

AB’SABER, A.N. Os domínios de natureza no Brasil: potencialidades paisagísticas. São Paulo: Ateliê Editorial, 2006.

ABREU, Capistrano de. Capítulos de História Colonial. Belo Horizonte: Editora Itatiaia Limitada, 2000.

ALENCASTRO, Luiz. O trato dos viventes: formação do Brasil no Atlântico Sul. São Paulo: Companhia das Letras, 2000.

ALVES, Joaquim. História das secas. Mossoró: Fundação Guimarães Duque/ ESAM, 1982.

AMADO, Janaína. Região, sertão, nação. Estudos Históricos, Rio de Janeiro, vol.8, n.15, 1995, p. $145-151$.

AMARAL, Francisco Pacífico do. Escavações: Fatos da história de Pernambuco. Recife: Arquivo Público Estadual, 1977.

ANDRADE, Manuel Correia de. A Pecuária e a Produção de Alimentos no Período Colonial. In: SZMRECSANYI, Tamás. (Org.). História Econômica do Período Colonial. São Paulo: Hucitec, 2002.

ANDRADE, Manuel Correia de. A Terra e o Homem no Nordeste. São Paulo: Brasiliense, 1963.

ANDREOLI, Rita.; KAYANO, Mary. A importância relativa do Atlântico Tropical Sul e Pacífico Leste na variabilidade de precipitação do Nordeste do Brasil. Revista Brasileira de Meteorologia, v.22, n.1, 63-74, 2007.

AB'SABER, A.N. Os domínios de natureza no Brasil: potencialidades paisagísticas. São Paulo:Ateliê Editorial, 2006

BARICKMAN, B. J. Um Contraponto Baiano: Açúcar, Fumo, Mandioca e Escravidão no Recôncavo, 1780-1860. Rio de Janeiro: Civilização Brasileira, 2003.

BONATO, Tiago. Viagens do Olhar: Relatos de Viajantes e a Construção do Sertão Brasileiro (1783-1822). Guarapuava: Unicentro, 2014.

BOSCHI, Caio César. O Brasil-Colônia nos arquivos históricos de Portugal. São Paulo: Alameda, 2011.

BOXER, Charles R. O império marítimo português (1415-1825). São Paulo: Companhia das Letras, 2002.

BRAUDEL, Fernand. Civilização Material, Economia e Capitalismo, séculos XV-XVIII. As estruturas do cotidiano. Vol. 3, São Paulo: Martins Fontes, 2009. 
BRITO, João Rodrigues de. Cartas econômico-políticas sobre a agricultura e comércio da Bahia, pelo Desembargador João Rodrigues de Brito. Lisboa: Imprensa Nacional, 1821.

CÂMARA, Leandro Calbente. Administração colonial e poder: a governança da cidade de São Paulo (1765-1802). Dissertação de mestrado. São Paulo: USP/FFLCH/PPGHE, 2008.

CÂMARA, Manuel Arruda da. Obras reunidas c. 1752-1811. Coligidas e com estudo biográfico por José Antonio Gonsalves de Mello. Recife: Fundação de Cultura Cidade do Recife, 1982.

CAMPOS, Nivalda Aparecida. A grande seca de 1979 a 1983: um estudo das ações do governo federal em duas sub-regiões do estado do Ceará (Sertão Central e Sertão dos Inhamuns). Dissertação de Mestrado. São Carlos: UFSCar/DCSo/PPGS, 2004.

CARDIM, Fernão. Tratado da terra e gente do Brasil. São Paulo: Companhia Editora COSTA, Francisco Augusto Pereira. Anais Pernambucanos. v. 1. Recife: Secretaria do Interior e Justiça, 1951-1966.

COUTO, Domingos do Loreto. Desagravos do Brasil e glórias de Pernambuco. Recife: Fundação de Cultura Cidade do Recife, [1757] 1981.

CROSBY, Alfred W. Imperialismo Ecológico. A expansão biológica da Europa: 900 - 1900. São Paulo: Companhia das Letras, 1991.

DIAS, Antônio Gonçalves. Diccionario da lingua tupy: chamada lingua geral dos indigenas do Brazil. Dresden: F.A. Brockhaus, 1858.

DIAS, Thiago Alves. Dinâmicas mercantis coloniais: Capitania do Rio Grande do Norte 17601821. Dissertação (Mestrado). UFRN, Natal, 2011

DIAZ, Henry F.; MARKGRAF, Vera. El Niño Historical and Paleoclimatic Aspects of the Southern Oscillation.. Londres: Cambridge University Press, 1993.

DUARTE, Renato. Do desastre natural à calamidade pública. A seca de 1998-1999. Fortaleza: Banco do Nordeste, 2002.

FERLINI, Vera Lúcia Amaral. A Civilização do Açúcar. $7^{\text {a }}$ ed. São Paulo: Brasiliense, 1991. FROTA, Luciara Silveira de Aragão. Estudo do Remanejamento da Pecuária na Zona Norte do Ceará $-1^{\circ}$ volume. 1786. Fortaleza: Superintendência do Desenvolvimento do Estado do Ceará (SUDEC) \& Universidade Vale do Acaraú, 1974.

GARDNER, George. Travels in the Interior of Brazil, Principally Through the Northern Provinces, and the Gold and Diamond Districts, During the Years1836-1841. Londres: Reeve, Benham, and Reeve, 1849. 
GUEDES, Paulo. No íntimo do Sertão: poder político, cultura e transgressão na Capitania da Paraíba (1750- 1800). Tese (doutorado em história). Universidade Federal de Pernambuco, 2013.

HOLANDA, Sérgio Buarque de. Caminhos e fronteiras. São Paulo: Companhia das Letras, 1994.

JOFFILY, Irenêo. Notas sobre a Parahyba. Brasília, Thesourus, s/d

KOSTER, Henry. Viagens ao Nordeste do Brasil. Trad. e notas L. C. Cascudo. São Paulo: Companhia Editora Nacional, 1942.

LINHARES, Maria Yedda Leite. História do abastecimento: uma problemática em questão. (1530-1918). Brasília: BINAGRI, 1979.

LINHARES, Maria Yedda.; SILVA, Francisco Carlos Teixeira da. História da Agricultura Brasileira. Combates e Controvérsias. São Paulo: Brasiliense, 1981.

LOPES, Fatima Martins. Missões Religiosas - Índios, Colonos e Missionários na Colonização do Rio Grande do Norte. Dissertação (Mestrado em História). Universidade Federal de Pernambuco, 1999.

LOPES, Gustavo Acioli. O saco de batatas colonial? Considerações sobre o uso do conceito de campesinato na historiografia do Brasil Colônia. Clio (Recife), v. 1, p. 46-65, 2011.

LUETZELBURG, Phillipp von. Estudo botânico do Nordeste. Rio de Janeiro: Inspetoria Federal de

MARENGO, J. Vulnerabilidade, impactos e adaptação à mudança do clima no semi-árido do Brasil. Parcerias Estratégicas, v.27, p.149-75, 2008.

MATTOSO, José. (org.). História de Portugal: o Antigo Regime. Lisboa: Estampa, 1993, p. 270.

MELO, Felipe Souza. O negócio de Pernambuco: financiamento, comércio e transporte na segunda metade do século XVIII. Dissertação de mestrado. São Paulo: USP/FFLCH/PPGHE, 2017

MENZ, Maximiliano M. Entre dois impérios: Formação do Rio Grande na Crise do Antigo Sistema Colonial (1777 - 1822). Tese de Doutorado. São Paulo: FFLCH, 2006.

MILLER, Joseph. The significance of drought, disease and famine in the agriculturally marginal zones of West-Central Africa. The Journal of African History, vol. 23, n. 1, jan. 1982. MINTZ, Sidney. Sweetness and Power. The Place of Sugar in Modern History. Lodres: Penguin, 1985.

MORAES, Antonio Carlos Robert. O Sertão. Terra Brasilis V. 4 - 5, 2003, p. 1-8. 
Nacional/MEC, 1978.

NÓBREGA, Ranyére.; SANTIAGO, Gabriela. Tendências do controle climático oceânico sob a variabilidade temporal da precipitação no Nordeste do Brasil. Revista Brasileira de Climatologia, v.18, n. 12, p. 276- 192, 2016.

NOVAIS, Fernando A. Portugal e Brasil na Crise do Antigo Sistema Colonial (1777-1808). $5^{\mathrm{a}}$ ed. São Paulo: Hucitec, 1989.

OLIVEIRA, Adriana Santos de. Pecuária, Agricultura e Comércio: Dinâmica das Relações Econômicas no Termo da Vila de Sobral. Dissertação (Mestrado). UFC, Fortaleza, 2015.

OLIVEIRA, Marcelo Almeida. As roças brasileiras, do período colonial à atualidade. Caracterização histórica e formal de uma categoria tipológica. VARIA HISTÓRIA, Belo Horizonte, vol.28, n 48, jul/dez, 2012, p. 755-780.

PALACIOS, Guillermo. Campesinato e escravidão no Brasil: Agricultores livres e pobres na Capitania Geral de Pernambuco (1700-1817). Brasília: Editora UnB, 2004.

PAULET, Antônio José da Silva. Descripção Geográfica Abreviada da Capitania do Ceará. RIHGB, Rio de Janeiro v.96, pt. 2, 1897.

PEDREIRA, Jorge Miguel Viana. “Agrarismo, Industrialismo, Liberalismo: algumas notas sobre o pensamento económico português (1780-1820)". In CARDOSO, J. L. (org.). Contribuição para a História do Pensamento Económico em Portugal. Lisboa: Dom Quixote, 1988.

PEDROZA, Manoela. A roça, a farinha e a venda: produção de alimentos, mercado interno e pequenos produtores no Brasil colonial. In: João Fragoso; Maria de Fátima Gouvêa. (Org.). $O$ Brasil Colonial. Rio de Janeiro: Civilização Brasileira, 2014, v. 3, p. 381-418.

PEREIRA, Joaquim José. Memória sobre a extrema fome e triste situação em que se achava o sertão da Ribeira do Apody. RIHGB, Rio de Janeiro, v. 20, 1857.

PEREIRA, Thales. The Cotton trade and Brazilian foreign commerce during the Industrial Revolution. Tese de doutoramento. São Paulo: USP/FEA/PPGE, 2017.

PINHEIRO, Francisco José. Notas sobre a formação social do Ceará, 1680-1820. Fortaleza: Fundação Ana Lima, 2008.

PITA, Sebastião da Rocha. História da América Portugueza. Bahia: Imprensa Econômica, 1878.

PRADO Jr., Caio. Formação do Brasil Contemporâneo. São Paulo: Editora Brasiliense, 1994. PUNTONI, Pedro. A guerra dos bárbaros: povos indígenas e a colonização do sertão nordeste do Brasil, 1650-1720. São Paulo: Editora Hucitec, 2002. 
REBOITA, Michele Simões.; SANTOS, Isimar. Influência de alguns padrões de teleconexão na precipitação do Norte e do Nordeste do Brasil. Revista Brasileira de Climatologia, v. 15, n. 10, Jul/Dez 2014.

RIBEIRO Jr. José. A economia algodoeira em Pernambuco. Da Colônia à independência. Revista Brasileira de História, v. 2 (set. 1981)1, p. 235-242.

RIBEIRO JR., J. Trabalho e fome numa economia colonial. História. São Paulo: USP, v. 2 (1983) p. 15-20.

ROLIM, Leonardo Cândido. “Tempo das Carnes" no Siará Grande: dinâmica social, produção e comércio de carnes secas na Vila de Santa Cruz do Aracati (c. 1690 -c. 1802). Dissertação (Mestrado). UFPB, João Pessoa, 2012.

SANT'ANNA NETO, João Lima. História da Climatologia no Brasil: gênese e paradigmas do clima como fenômeno geográfico. Cadernos Geográficos, Florianópolis, n. 7. maio, 2004.

SCHAMA, Simon. Paisagem e Memória. São Paul: Companhia das Letras, 1996.

SCHWARTZ, Stuart. Escravos, roceiros e rebeldes. São Paulo: EDUSC, 2001.

SILBERT, Albert. Do Portugal de antigo regime ao Portugal oitocentista. Lisboa: Horizontes, 1977.

SILVA, Antônio de Moraes. Dicionário da Língua Portugueza Composto por Antônio de Moraes e Silva. Lisboa: Impressão Régia, 1831.

SILVA, Francisco Carlos Teixeira da. A Morfologia da Escassez: crises de subsistência e política econômica no Brasil colônia (Salvador e Rio de Janeiro, 1680-1790). Tese de doutoramento. Niterói: UFF/ICHF/PPGHIS, 1990.

SILVA, Kalina Vanderlei. Nas Solidões Vastas e Assustadoras: A conquista do sertão de Pernambuco pelas vilas açucareiras nos séculos XVII e XVIII. Recife: CEPE.

SILVA. Ignacio Accioli de Cerqueira. Memórias históricas e políticas da província da Bahia. Salvador: Typ. Do Correio Mercantil, 1835.

SILVA. Roberto Marinho da. Entre o combate à seca e a convivência com o semi-árido: transições paradigmáticas e sustentabilidade do desenvolvimento. Tese de doutoramento. Brasília: UnB/ CDS/PPGDS, 2006.

SMITH, Adam. Uma investigação sobre a natureza e causas da riqueza das nações. Rio de Janeiro, Ediouro, 1986

SOUZA, Gabriel Soares de. Tratado descritivo do Brasil em 1587. Belo Horizonte: Itatiaia, 2000. 
SOUZA, George. F. C. de. Saciar para manter a ordem e o bem público: a Câmara Municipal do Recife e o problema do abastecimento da vila (século XVIII). Locus (UFJF), v. 38 (2014) p. $103-120$.

THOMPSON, E. P. Costumes em comum. Estudos sobre a cultura popular tradicional. São Paulo: Companhia das Letras. 2008.

TOMICH, Dale W. Pelo prisma da escravidão. Trabalho, Capital e Economia mundial. São Paulo: Edusp, 2011.

VANDELLI, Domingos. Memórias de História Natural. Porto: Porto Editora, 2003.

VIOTTI, Ana Carolina. As práticas e os saberes médicos no Brasil Colonial (1677-1808).

Dissertação de Mestrado. Franca: Unesp/ FCS/ PPGH, 2012.

XAVIER, T. M. B. S. ; XAVIER, Airton Fontenele Sampaio ; DIAS, P. L. S. ; DIAS, M. A. F. S. . Interrelações dos Eventos ENOS (ENSO), da ZCIT (ITCZ) no Atlântico e da Chuva nas Bacias Hidrográficas do Ceará. Revista Brasileira de Recursos Hídricos, v. 8, n.2, p. 111-126, 2003.

XAVIER, Teresinha. TEMPO DE CHUVA - Estudos Climáticos e de Previsão para o Ceará e Nordeste Setentrional. Fortaleza-: Editora ABC, 2001. 


\section{Fontes}

\section{Arquivo Histórico Ultramarino - Lisboa}

\section{- Documentos Avulsos do Ceará}

AHU- Avulsos do Ceará, D. 124. Ceará, 06 de setembro de 1731. Requerimento de Manuel da Silva Lima e Jerônimo da Fonseca, moradores na vila de São José do Ribamar, ao rei, D. João $\mathrm{V}$, a pedir sejam perdoados parte dos dízimos que arremataram por causa de uma violenta cheia que matou o gado.

AHU - Avulsos do Ceará, D 325. Aracati, 18 de dezembro de 1748. Carta da câmara da vila do Aracati ao rei D. João V, sobre a seca que desde o ano de 1743 tem assolado a Capitania do Ceará e a falta de escravos, que se refugiam nas missões.

AHU - Ceará, D. 590. Ceará, s/d 1782. Ofício do capitão-mor do Ceará, João Batista de Azevedo Coutinho de Montauri, a Martinho de Melo e Castro, sobre as condições de abastecimento.

AHU - Ceará, D. 644. Quixeramobim, 03 de fevereiro de 1787. Carta do Ouvidor do Ceará Manuel Avelar, à Rainha D. Maria, sobre a situação econômica da referida capitania.

AHU - Ceará, D. 697. Ceará, 23 de agosto de 1794. Requerimento de Antônio Gomes Albuquerque e do sargento-mor Manuel Francisco de Vasconcelos, arrematantes do contrato dos dízimo reais da freguesia da Conceição da Nossa Senhora do Sobral, à rainha, D. Maria, a pedir consignação favorável às suas dívidas, devido à seca de 1791-92, que ocasionou a morte do gado.

\section{- Documentos Avulsos da Paraíba}

AHU - Avulsos da Paraíba, D. 329 . Paraíba, 27 de maio de 1712.Carta do Capitão- mor da Paraíba, João da Maia da Gama, ao rei, D. João V, sobre os prejuízos com a seca de 1710 a 1712

AHU - Avulsos da Paraíba, D. 416. Paraíba, 24 de junho de 1724. Carta do Capitão-mor da Paraíba, João de Abreu Castel Branco, ao rei, D. João V, sobre a difícil situação da capitania, em consequência da seca e o lançamento de um bando para punir vadios e ladrões.

AHU - Avulsos da Paraíba, D. 452. Paraíba, 21 de julho de 1725. Carta do Capitão-mor da Paraíba, João de Abreu Castel Brando, ao rei, D. João V, sobre as dificuldades com a calamidade da seca e morte de mais da metade dos escravos.

AHU - Avulsos da Paraíba, D. 416. Paraíba, 24 de junho de 1724. Carta do Capitão-mor da Paraíba, João de Abreu Castel Branco, ao rei, D. João V, sobre a difícil situação da capitania, em consequência da seca e o lançamento de um bando para punir vadios e ladrões.

AHU - Paraíba, D. 606. Paraíba, 19 de outubro de 1729. Consulta do Conselho Ultramarino, ao rei D. João V, sobre a carta do capitão-mor da Paraíba, Francisco Pedro de Mendonça Gorjão, informando da cheia que houve na Capitania, destruindo engenhos e lavradores, em que solicitam para não serem executadas em suas fábricas as dívidas que possuem.

AHU -Paraíba, D. 796. Paraíba, 13 de abril de 1736. Carta do capitão-mor da Paraíba, Pedro Monteiro de Macedo, ao rei D. João V, sobre o empréstimo que recebeu da Coroa de quatrocentos e oitenta mil réis, para a capitania e a dificuldade em honrar o compromisso, devido à falta de moedas de ouro, por não ser essa cidade terra de negócio, e em razão da grande seca, não virem mineiros comprar cavalos.

AHU - Avulsos da Paraíba, D. 830. Paraíba, 14 de janeiro de 1738. Carta do capitão-mor da paraíba, Pedro monteiro de Macedo, ao rei, D. João V, sobre as dificuldades com uma seca, uma inundação e a falta de pagamento.

AHU - Avulsos da Paraíba, D. 2447. Paraíba, 10 de setembro de 1798. Carta do governador da Paraíba, Fernando Delgado Freire de Castilho, à rainha, D. Maria, sobre o estado de 
conservação das matas; e remetendo relação das datas de sesmarias passada pelo governo da Paraíba a partir de 1678.

AHU - Avulsos da Paraíba, D. 2510. Paraíba, 31 de julho. Ofício do governador da Paraíba Fernando Delgado Freire de Castilho, ao secretário de Estado da Marinha e Ultramar, Rodrigo de Sousa Coutinho, remetendo mapas gerais relativos aos preços, à exportação, à importação, ao movimento marítimo, à população, aos nascimentos, casamentos, mortes e à ocupação dos habitantes da Paraíba, no ano de 1798

AHU - Avulsos da Paraíba, D. 2173. Paraíba, 12 de abril de 1787. Ofício do Governador da Paraíba, coronel Jeronimo José de Melo e Castro, informando dos problemas de jurisdição de um governo subordinado.

AHU - Avulsos da Paraíba, D. 2178. Paraíba, 28 de maio de 1787. Ofício do governador da Paraíba ao secretário de estado da Marinha e Ultramar, informando da preferência dos lavradores em cultivar o algodão

AHU - Avulsos da Paraíba, D. 2354. 19 de abril de 1796. OFÍCIO do Governador da Paraíba, Brigadeiro Jerónimo José de Melo e Castro, ao Secretário de estado da Marinha e Ultramar, Luís Pinto de Sousa Coutinho, informando da calamidade que trouxe a seca, destruindo as colheitas e o gado, trazendo um número enorme de pessoas para o litoral.

AHU - Avulsos da Paraíba, D. 2268. Paraiba, 17 de julho de 1792. Ofício do Governador da Paraiba, coronel Jerónimo José de Melo e Castro, ao secretário de estado da Marinha e Ultramar, Martinho de Melo e Castro, informando da fome na capitania, com os mais sofridos a roubarem alimentos; e ter escrito ao governo da Bahia em busca de socorro, pedindo dois navios de farinha.

AHU - Avulsos da Paraíba, D. 2258. Paraíba, 21 de abril de 1792. Ofício do Governador da Paraíba, Coronel Jeronimo José de Melo e Castro ao Secretário de Estado Da Marinha e Ultramar, Matinho de Melo e Castro, informando da falta de farinha, provocada pela seca. AHU - Avulsos da Paraíba, D. 2287. Paraíba, 26 de junho de 1793. Carta dos oficiais da Câmara da Paraíba à rainha, D. Maria, informando das calamidades da seca, e queixando-se dos procedimentos vexatórios tomados pelo governador da Paraíba, Brigadeiro Jerônimo de Melo e Castro.

AHU - Avulsos da Paraíba, D. 2286. Paraíba. 8 de junho de 1793. Carta dos oficiais da Câmara da Paraíba, à Rainha (D. Maria I), informando da calamidade que a seca trouxe à vila do Pilar do Taipu; e queixando-se dos procedimentos do governador da Paraíba para sanar os problemas da estiagem.

AHU - Avulsos da Paraíba, D. 2254. Paraíba, 14 de março de 1792. Ofício do Governador da Paraíba, coronel Jeronimo José de Melo e Castro, informando dos males da seca e da finta que lançou sobre os fabricantes de farinha no contorno da cidade, inclusive da prisão de um dos fintados.

AHU - Avulsos da Paraíba, D. 2258. Paraíba, 21 de abril de 1792. Ofício do Governador da Paraíba, Coronel Jeronimo José de Melo e Castro ao Secretário de Estado Da Marinha e Ultramar, Matinho de Melo e Castro, informando da falta de farinha, provocada pela seca.

\section{- Documentos Avulsos de Pernambuco}

AHU- Avulsos de Pernambuco, D. 6306. Recife, 14 de janeiro de 1754. Ofício do Governador da capitania de Pernambuco, Luis José Correia de Sá, ao secretário de estado da Marinha e Ultramar, Diogo de Mendonça Corte Real, sobre a seca que se abateu naquela capitania.

AHU - Avulsos de Pernambuco, D. 9081. Recife, 4 de abril de 1775. Ofício do governador da capitania de Pernambuco, José César de Meneses, ao secretário de estado da Marinha e Ultramar, Martinho de Melo e Castro, sobre a seca que assola a dita capitania, principalmente o sertão, chegando até a ilha de Fernando de Noronha. 
AHU - Avulsos de Pernambuco, D. 9308. Recife, 6 de março de 1776. Ofício do governador da capitania de Pernambuco, José César de Menezes, ao Secretário de estado da Marinha e Ultramar, Martinho de Melo e Castro, sobre o destacamento enviado para a ilha de Fernando de Noronha e os desertores e soldados presos por desordens e crimes também enviados à mesma; informando também da seca que continua assolar a região e do falecimento de várias pessoas com o mal de Luanda e bexigas.

AHU- Avulsos de Pernambuco, D. 10163. Recife, 7 de maio de 1780. Oficio do governador da capitania de Pernambuco, José César de Meneses, aos secretário de estado da Marinha e Ultramar, Martinho de Melo e Castro, sobre o envio de presos e mantimentos para o presídio de Fernando de Noronha, e informando acerca da rigorosa seca e elevada mortandade de gado naquela ilhas, e que há madeira no porto de Jaraguá pronta para ser embarcada para o Reino. AHU- Avulsos de Pernambuco, D. 9574. Recife, 6 de março de 1777. Ofício da Mesa da Inspeção da capitania de Pernambuco ao secretário de estado da Marinha e Ultramar, Martinho de Melo e Castro, sobre se acrescentar 200 réis em cada arroba de açúcar, para acrescentar o referido gênero, por causa da diminuta colheita do dito ano.

AHU - Avulsos de Pernambuco, D. 9889. Recife, 17 de outubro de 1778. Ofício do governador da capitania de Pernambuco, José César de Meneses, ao secretário de estado da Marinha e Ultramar, Martinho de melo e Castro, sobre uma boa safra de açúcar no ano de 1778, devido ao tempo favorável, mas que a seca assola o sertão provocando a morte do gado.

AHU- Avulsos de Pernambuco, D. 12437. Recife, 16 de agosto de 1791, agosto, 16, Recife. Carta do governado da capitania de Pernambuco, D. Tomás José de Melo à Rainha D. Maria, Informando a representação dos oficiais da Câmara da Paraíba sobre os prejuízos causados pelas enchentes e os benefícios que pedem os senhores dos engenhos, donos de partidos e lavradores de cana.

AHU - Avulsos de Pernambuco, D. 12587. Recife, 25 de maio de 1792. Ofício do governador da capitania de Pernambuco D. Tomás José de Melo, ao secretário de estado da Marinha e Ultramar, Martinho de Melo e Castro, remetendo os documentos referentes a epidemia na capitania do Ceará

AHU - Avulsos de Pernambuco, D. 9665. Recife, 30 de setembro de 1777. Ofício do Governador, José Cesar de Meneses ao secretário de estado da Marinha e Ultramar, Martinho de Melo e Castro, remetendo o mapa da enumeração dos povos da dita capitania.

AHU - Avulsos de Pernambuco, D. 13809. Recife, 14 de maio de 1798. Ofício do governador da capitania de Pernambuco, D. Tomás José de Melo, ao secretário de estado da marinha e ultramar, D. Rodrigo de Sousa Coutinho, sobre as recomendações para se usar bois e arados para cultivar as terras, enviando uma breve descrição dos métodos do cultivo da terra e manipulação dos gêneros que se exportam daquela capitania.

AHU - Avulsos de Pernambuco. D. 11530. Recife, 30 de agosto de 1787. Ofício do ouvidor da capitania de Pernambuco, Antônio Xavier Moraes Teixeira Homem, ao secretário de estado da Marinha Ultramar, Martinho de Melo e Castro, sobre a situação da justiças nos julgados da comarca de Olinda, Garanhuns, Tacaratu e Cabrobó, e sugerindo a elevação de todas à vila, e informando o desenvolvimento comercial de Paudalho e de Santo Antão da Mata, e a necessidade de transforma-las em vilas.

AHU - Avulsos de Pernambuco, D. 1967 Recife, 09 de abril de 1704. Carta dos oficiais da câmara do Recife ao Rei, D. Pedro II sobre a proibição aos lavradores com menos de seis escravos, e pedindo para que o cultivo da farinha de mandioca fosse realizado pelos lavradores com menos de três escravos.

AHU - Avulsos de Pernambuco, D. 13603. Recife, 21 de agosto de 1797. Carta do governador da capitania de Pernambuco, Tomás José de Melo, à rainha, D. Maria, informando seu parecer sobre um edital expedido pela Câmara do Recife, referente a proibição da entrada de carga de algodão sem levar também a farinha de mandioca. 
AHU - Avulsos de Pernambuco, D. 7793. Recife, 23 de julho de 1763. Carta dos oficiais da câmara do Recife ao rei D. José, sobre a falta de plantações de mandiocas para o sustento das famílias devido aos estragos feitos pelos gados, e a imposição de novas penas para os lavradores que não plantarem lavouras suficiente para o bem comum e sustento de suas famílias.

AHU - Avulsos de Pernambuco, D. 10183. Recife, 3 de junho de 1780. Ofício do governador da capitania de Pernambuco, José César de Meneses, ao secretário de estado da Marinha e Ultramar, Martinho de Melo e Castro, sobre a subida do preço da mandioca, em razão da preferência dos agricultores pela lavou de cana do açúcar.

AHU - Avulsos de Pernambuco, D. 9561. Recife, 25 de fevereiro de 1777. Oficio do Governador sobre se introduzir a cultura do algodão e do arroz na dita capitania e anexa.

AHU- Avulsos de Pernambuco, D. 13658. Recife, 10 de janeiro de 1798. Ofício do Governador da Capitania de Pernambuco, D. Tomás José de Melo, ao Secretário de Estado da Marinha e Ultramar, informando o parecer sobre a situação econômica da Capitania de Pernambuco AHU - Avulsos de Pernambuco, D. 13117. Recife, 15 de setembro de 1795. OFÍCIO do governador da Capitania de Pernambuco, D. Tomás José de Melo, ao secretário do estado dos Negócios Estrangeiros e da Guerra e interinamente da Marinha e Ultramar, Luís Pinto de Sousa Coutinho, sobre as providências que tomou em relação a cultura de mandioca, informando que a seca que assolou a Capitania nos últimos anos deixou a terra estéril e matou a terça parte da população

AHU - Avulsos de Pernambuco, D. 12942. Lisboa, 30 de setembro de 1794. Relação feita pelo secretário do Conselho Ultramarino, Francisco de Borja, dos papéis da capitania de Pernambuco que baixaram com o aviso nesta Secretaria, referindo-se a contas da Junta da Fazenda Real, informações do contador geral e da câmara de Igarassu, sobre o contrato do subsídio das carnes. AHU - Avulsos de Pernambuco, D. 14497. Recife, 18 de janeiro de 1800. Oficio da Junta Governativa da capitania de Pernambuco ao secretario de estado da Marinha Ultramar Rodrigo de Sousa Coutinho, sobre aparecer a respeito da representação dos negociantes e proprietários de engenho sobre o pagamento do subsidio literário da carne seca.

\section{- Documentos Avulsos do Rio Grande do Norte}

AHU - Avulsos do Rio Grande do Norte, D. 10. 22 de junho de 1667. Requerimento do sargento-mor Pedro Borges Pacheco e do capitão Francisco de Abreu de Lima ao príncipe regente, D. Pedro, pedindo confirmação de carta de sesmaria de terra na Ribeira do CearáMirim, passada pelo governador-geral do Brasil Alexandre de Sousa Freire.

\section{- Documentos Avulsos do Rio de Janeiro}

AHU- Avulsos do Rio de Janeiro, D. 11246. Rio de Janeiro, 22 de junho de 1792. Ofício do Vice-rei do Estado do Brasil, Conde Resende, ao secretário de estado da marinha e ultramar Martinho de Melo e Castro, sobre a ajuda solicitada pelo governador de Pernambuco para que fosse remetida àquela Capitania farinha de mandioca; e a tentativa da Câmara do Rio de Janeiro de tentar impedir a referida remessa.

AHU - Avulsos do Rio de Janeiro D, 11332. Rio de Janeiro, 22 de dezembro de 1792. Ofício do juiz de Fora do Rio de Janeiro, Baltazar da Silva Lisboa, ao Secretário de Estado da Marinha e Ultramar, Martinho de Melo e Castro, sobre a devassa que procedeu contra o contrabando de farinha de mandioca e outros mantimentos exportado por negociação fraudulenta para Pernambuco com detrimento dos povos.

AHU - Avulsos do Rio de Janeiro D, 11355. Rio de Janeiro, 8 de março de 1793. Ofício do Juiz de Fora do Rio de Janeiro, Baltazar da Silva Lisboa, ao Secretário de estado da Marinha e Ultramar, Martinho de Melo e Castro, informando o contrabando dos mantimentos que foram 
objeto da devassa que implica o procurador da Fazenda, João de Figueiredo, o ajudante de ordens Gaspar José de Matos e diversos militares

\section{- Bahia (Eduardo de Castro e Almeida)}

AHU - Bahia (Eduardo de Castro e Almeida), D, 14901. Bahia, 9 de julho de 1792 Oficio do Governador D. Fernando José de Portugal para Martinho de Mello e Castro, no qual se refere à falta de farinha de pao na Capitania de Pernambuco e no Reino de Angola, por causa da seca extraordinária que tinham sofrido, e as providências que tomara para os socorrer.

\section{Arquivo Público Jordão Emerenciano - Pernambuco}

- Registro de Provisões, Portarias, Editais e Bandos (4/2)

- Ofícios do Governo (3) (4)

\section{Instituto Arqueológico, Histórico e Geográfico de Pernambuco}

- Livros de Atas da Câmara Municipal do Recife

- Livros de Registros da Câmara Municipal do Recife (1733-1808)

\section{Instituto Histórico do Rio Grande do Norte}

- Livro de Termos de Vereação do Senado da Câmara de Natal (1784 - 1803)

- Livro de Termos de Vereação do Senado da Câmara de Natal (1674 - 1698) 